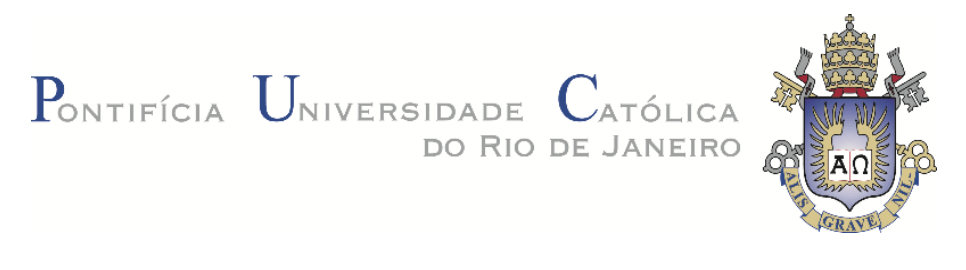

Carla da Conceição de Lima

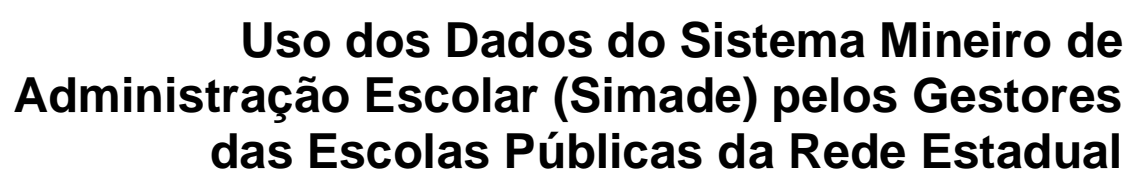

Tese de Doutorado

Tese apresentada como requisito parcial para obtenção do grau de Doutor pelo Programa de Pósgraduação em Educação da PUC-Rio

Orientadora: Profa. Cynthia Paes de Carvalho Co-orientador: Prof. Luis Antônio Fajardo Pontes

Rio de Janeiro

Fevereiro de 2019. 


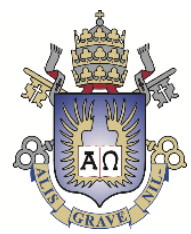

Carla da Conceição de Lima

\title{
Uso dos Dados do Sistema Mineiro de Administração Escolar (Simade) pelos Gestores das Escolas Públicas da Rede Estadual
}

\begin{abstract}
Tese apresentada como requisito parcial para obtenção do grau de doutor pelo Programa de Pós-graduação em Educação do Departamento de Educação do Centro de Teologia e Ciências Humanas da PUC-Rio. Aprovada pela Comissão Examinadora abaixo assinada.
\end{abstract}

Prof. ${ }^{\text {a }}$ Cynthia Paes de Carvalho

Orientadora

Dep. de Educação - PUC-Rio

Prof. Luis Antônio Fajardo Pontes

Co-orientador

CAEd/UFJF

Prof. ${ }^{-}$Roberta Gurgel Azzi

TSC - Centro de Estudos e Pesquisas

Prof. a Ana Cristina Prado de Oliveira

UNIRIO

Prof. a Rosália Maria Duarte

Dep. de Educação - PUC-Rio

Prof." Gilda Helena Bernardino de Campos

Dep. de Educação - PUC-Rio

Prof. - Denise Berruezo Portinari

Coord. Set..I do Centro de Teologia e C. Humanas da PUC-Rio

Rio de Janeiro, 18 de fevereiro de 2019 
Todos os direitos reservados. É proibida a reprodução total ou parcial do trabalho sem autorização da universidade, da autora e do orientador.

\section{Carla da Conceição de Lima}

Graduou-se como Tecnóloga em Processamento de Dados pelo Centro de Ensino Superior de Juiz de Fora (CES/JF) e possui especialização em Engenharia de Software pela mesma instituição. Possui especialização em Gestão e Avaliação da Educação Pública pela UFJF. Concluiu o Mestrado em Educação na Pontifícia Universidade Católica de Petrópolis, em 2010. Na área da Educação, sua experiência e atuação se relacionam, principalmente, aos seguintes temas: políticas públicas, gestão escolar, sistema de gestão escolar e TIC. Desde 2015 é pesquisadora no grupo de pesquisa Gestão e Qualidade da Educação - GESQ, com foco em gestão da escola e qualidade do ensino público, tendo publicado artigo com essa temática. Atuou profissionalmente na Educação Básica por quatro anos, como professora, por seis anos como Analista de Políticas Públicas e dois anos como tutora de cursos de formação continuada para professores, diretores e técnicos das secretarias estaduais e municipais de educação.

Ficha Catalográfica

Lima, Carla da Conceição de

Uso dos dados do Sistema Mineiro de Administração Escolar (SIMADE) pelos gestores das escolas públicas da rede estadual / Carla da Conceição de Lima ; orientadora: Cynthia Paes de Carvalho ; co-orientador: Luís Antônio Fajardo Pontes. - 2019.

228 f. : il. color. ; $30 \mathrm{~cm}$

Tese (doutorado)-Pontifícia Universidade Católica do Rio de Janeiro, Departamento de Educação, 2019.

Inclui bibliografia

1. Educação - Teses. 2. Diretores escolares. 3. SIMADE. 4. Autoeficácia. I. Carvalho, Cynthia Paes de. II. Pontes, Luís Antônio Fajardo. III. Pontifícia Universidade Católica do Rio de Janeiro. Departamento de Educação. IV. Título. 
Aos Diretores, Secretários Escolares e Assistentes Técnicos da Educação Básica (ATB) que conseguem, a despeito de inúmeros desafios que enfrentam, fazer com que a organização administrativa, e indiretamente pedagógica, funcione nas escolas. 


\section{Agradecimentos}

Agradeço, em primeiro lugar, a Deus pela oportunidade de estudar em uma instituição como a PUC-Rio.

Aos meus amores, minha mãe e minha avó, por sempre valorizar meus estudos e acreditarem que eu seria a primeira da família a me tornar doutora. Agradeço por compreenderem minhas ausências e vibrarem comigo a cada vitória. Em especial, agradeço a minha mãe, por ter sido referência para a minha compreensão sobre a importância da gestão escolar. Vocês são pessoas que iluminam a minha vida.

À orientadora, professora Cynthia Paes de Carvalho, sempre atenciosa e precisa, e ao meu co-orientador, professor Luis Antônio Fajardo Pontes, pela segurança de sua supervisão.

À professora Gilda, pelo carinho, pela ajuda e paciência em me escutar, oferecendo ideias e sugestões para o desenvolvimento desta pesquisa. À professora Rosália Duarte, pela interlocução na elaboração dos questionários dessa pesquisa. Ao professor Murillo Marschner Alves de Brito, pelos diálogos frutíferos que me fizeram observar realmente o foco da pesquisa.

Ao CNPq e à PUC-Rio, pelos auxílios financeiros e a formação acadêmica, sem os quais este trabalho não poderia ser realizado.

O presente trabalho foi realizado com apoio da Coordenação de Aperfeiçoamento de Pessoal de Nível Superior - Brasil (CAPES) - código de financiamento 001.

Aos professores que compuseram as minhas bancas, pelas leituras e valiosas contribuições.

Aos professores do Programa de Pós-graduação em Educação da PUC-Rio pela competência do trabalho desenvolvido no âmbito da pesquisa em educação.

Agradeço à equipe da Secretaria Estadual de Educação de Minas Gerais (SEE/MG), que se empenhou para viabilizar meu acesso às escolas e a Secretaria Municipal de Educação de Juiz de Fora pela autorização da aplicação do pré-teste dos instrumentos da pesquisa.

Agradeço ao Centro de Políticas Públicas e Avaliação da Educação, da Universidade Federal de Juiz de Fora, pela disponibilização dos materiais sobre o SIMADE.

Aos Diretores, Secretários Escolares e Assistentes Técnicos da Educação Básica (ATBs) que participaram desta pesquisa, meu profundo agradecimento.

Por fim, agradeço aos meus companheiros do GESQ, por compartilharem experiências, conhecimento e inspirarem novas reflexões, contribuindo para que eu pudesse vencer os desafios. 


\section{Resumo}

Lima, Carla da Conceição de; Paes de Carvalho, Cynthia (orientador). Uso dos dados do Sistema Mineiro de Administração Escolar (SIMADE) pelos gestores das escolas públicas da rede estadual. Rio de Janeiro, 2019. 228 p. Tese de Doutorado - Departamento de Educação, Pontifícia Universidade Católica do Rio de Janeiro.

Diante da informatização das escolas e tendo em vista a necessidade de maior eficiência, eficácia e produtividade das unidades de ensino, o estado de Minas Gerais implementou, em 2008, o Sistema Mineiro de Administração Escolar (SIMADE) em todas as escolas públicas da rede estadual. Esse sistema permite a organização dos dados educacionais e, a partir deles, a proposição de ações, estratégias e intervenções com intuito de melhorar a qualidade da educação. Investigamos quais têm sido os usos dos dados do SIMADE como ferramenta de gestão para os diretores da rede estadual de Minas Gerais. Usamos como referência analítica os conceitos de gestão escolar, dados e autoeficácia do diretor. Foi aplicado um survey aos diretores e aos integrantes da equipe da secretaria de todas as escolas da rede estadual. Obtivemos respostas de 586 escolas, a maioria das quais atende ao Ensino Fundamental e Médio. Os principais resultados são: (i) os diretores têm menos tempo de atuação na função se comparados aos secretários e ATBs, embora tenham maior escolarização, os diretores dedicam um tempo quase igual à gestão administrativa e pedagógica; (ii) os computadores, em geral, estão em bom estado de conservação, o acesso ao SIMADE é considerado bom e a frequência de acesso ao sistema é maior por parte dos secretários e ATBs, que se mostraram satisfeitos com a usabilidade do sistema; (iii) os diretores estão distribuídos em três níveis de autoeficácia baixa, adaptativa e alta; (iv) o SIMADE é considerado uma das fontes de informação mais utilizadas dentro da escola. O uso do sistema, na perspectiva dos sujeitos da pesquisa, possui mais fins administrativos que pedagógicos, ainda que o detalhamento registrado por eles sobre as formas de uso do sistema apresente indícios de ser mais pedagógico, indicando 
percepções possivelmente variadas sobre o sentido dos possíveis usos pedagógicos.

\section{Palavras-chave}

Diretores escolares; SIMADE; Autoeficácia. 


\section{Abstract}

Lima, Carla da Conceição de; Paes de Carvalho, Cynthia (advisor). Use of data from the Minas Gerais School Administration System (SIMADE) by public school managers of the state network. Rio de Janeiro, 2019. 228 p. Tese de Doutorado - Departamento de Educação, Pontifícia Universidade Católica do Rio de Janeiro.

Faced with the computerization of schools (since the existence of computers and internet in the units) and in view of the need for greater efficiency, effectiveness and productivity of educational units, the state of Minas Gerais implemented in 2008 the Minas Gerais System of School Administration (SIMADE) in all public schools of the state educational system. This administrative system allows the organization of educational data and, based on them, the proposition of actions, strategies and interventions in order to improve the quality of education. In this work, we investigate the use of SIMADE data as a management tool for the principals of the Minas Gerais state educational system. We use as an analytical reference the concepts of school management, data and self-efficacy of the director. A survey was applied to the directors and members of the staff of the secretariat of all schools in the state system. We obtained responses from 586 schools - in which the principal and secretary or technical assistant of basic education (ATB) answered the questionnaire - most of which attend Elementary and Secondary School. The main results are: (i) the principals have less time in the function compared to the secretaries and ATBs; although more educated, principals dedicate almost equal time to the administrative and pedagogical management; (ii) computers are generally in good condition, access to SIMADE is considered good and the frequency of access to the system is greater by the secretaries and ATBs, who were satisfied with the usability of the system; (iii) the principals are distributed in three levels of selfefficacy - low, adaptive and high; (iv) SIMADE is considered one of the most used information sources within the school. The use of the system, from the perspective of the subjects of the research, has more administrative than pedagogical purposes, although the details recorded in their answers 
about the use of the system show signs of more pedagogical use, indicating possibly different perceptions about the meaning of possible pedagogical uses of the system.

\section{Keywords}

School principals; SIMADE; Self-efficacy 


\section{SUMÁRIO}

Introdução

1 Situando o objeto no contexto da pesquisa educacional: sistemas de gestão escolar e o SIMADE 199

1.1 Sistemas de gestão escolar: o que dizem as pesquisas 277

1.2 O Sistema Mineiro de Administração Escolar (SIMADE) como política pública

1.3 O Sistema Mineiro de Administração Escolar (SIMADE): atores escolares

1.5 O Sistema Mineiro de Administração Escolar (SIMADE) como sistema de gestão

477

2. Delineamento da pesquisa: o problema, as hipóteses, as questões, os objetivos e o caminho metodológico

2.1 O caminho metodológico

2.2 O pré-teste na rede pública municipal de Juiz de Fora: validação dos instrumentos

2.3 A elaboração dos questionários das escolas estaduais de Minas Gerais: aprofundando o referencial teórico

2.4. Quadro geral dos questionários aplicados nas escolas estaduais de Minas Gerais

2.5 A seleção da amostra e a coleta de dados nas escolas estaduais de Minas Gerais

3 A amostra considerada neste trabalho: o uso dos dados do

SIMADE 80

3.1 Características das escolas 80

3.1.1 As avaliações em larga escala 844

3.1.2 Características dos sujeitos 888

3.2 A infraestrutura tecnológica do SIMADE 977

3.2.1. Os equipamentos e os acessos à internet e ao SIMADE 988

3.2.2 A formação dos recursos humanos para utilização do SIMADE 1044 
4. A autoeficácia dos diretores escolares

4.1. Possíveis associações entre o indicador de autoeficácia, a idade do diretor, o desempenho da escola, as fontes de informação e as tarefas da direção da unidade de ensino 1155

4.2 A autoeficácia e o SIMADE: uso dos dados na gestão da escola 1244

4.3 A autoeficácia do diretor e o uso dos dados do SIMADE

5. Considerações finais 1388

Referências bibliográficas

Anexos 


\section{Lista de Figuras}

Figura 1- Tela inicial do SIMADE.

Figura 2 - Relatórios do SIMADE. 


\section{Lista de Tabelas}

Tabela 1: Usabilidade do SIMADE.

Tabela 2: Distribuição de matrículas nas redes públicas e privada de Minas

Gerais.

Tabela 3: Segmentos atendidos pelas escolas.

Tabela 4: Estatísticas descritivas de matrículas, segundo segmentos oferecidos. 82

Tabela 5: Tempo na direção desta escola.

Tabela 6: Cargas fatoriais das variáveis relativas ao Indicador de

Complexidade da Gestão.

Tabela 7: Distribuição de escolas, segundo grupamento e análise de níveis de complexidade de gestão.

Tabela 8: Tempo na função.

Tabela 9: Escolarização dos respondentes.

Tabela 10: Dedicação dos diretores e vice-diretores aos tipos de gestão.

Tabela 11: Acesso ao SIMADE.

Tabela 12: Acesso ao SIMADE pelos secretários e ATBs.

Tabela 13: Categorias - usabilidade, eficiência, funcionalidade e confiabilidade.

Tabela 14: Estatística descritiva dos resultados da Análise Fatorial para o cálculo do indicador de autoeficácia do diretor.

Tabela 15: Fontes de informação usadas pelo Diretor.

Tabela 16: Indique com que frequência você realiza as seguintes atividades no seu trabalho na direção escolar

Tabela 17: Distribuição das categorias administrativa e pedagógica por autoeficácia.

Tabela 18: Quantidade de respostas positivas por variável sobre uso dos dados e nível de autoeficácia.

Tabela 19: Indique com que frequência você utiliza os dados do SIMADE para:. 


\section{Lista de Quadros}

Quadro 1: procedimentos realizados e ajustes necessário para a aplicação do questionário.

Quadro 2: Ajustes necessários aos questionários. 


\section{Lista de Gráficos}

Gráfico 1: Nível de autoeficácia computacional para utilizar o SIMADE. 106

Gráfico 2: Distribuição do indicador de autoeficácia dos diretores. 113

Gráfico 3: Indicador de autoeficácia e faixa etária dos diretores. 116

Gráfico 4: Média dos quatro escores em matemática (média geral de

$\begin{array}{ll}\text { Matemática). } & 118\end{array}$

Gráfico 5: Considero a utilização do SIMADE bastante fácil. 135

Gráfico 6: Estou bastante confiante na minha capacidade para utilizar o

$\begin{array}{ll}\text { SIMADE. } & 136\end{array}$

Gráfico 7: O SIMADE me ajuda a poupar tempo na realização de minhas

Atividades. 136 


\section{INTRODUÇÃO}

As características do trabalho do diretor escolar, especialmente no que tange aos sistemas de gestão escolar, são tema de meu interesse pessoal desde o início de minha experiência profissional, no Centro de Políticas Públicas e Avaliação da Educação, da Universidade Federal de Juiz de Fora (CAEd/UFJF), no qual atuei de 2007 a 2016 ${ }^{1}$. Entre 2007 e 2014, operei como analista, principalmente no processo de implementação e orientação das escolas e secretarias (municipais e estaduais) de educação acerca do uso dos sistemas de gestão escolar, sendo eles o Sistema para Administração e Controle Escolar (SisLAME) e o Sistema Mineiro de Administração Escolar (SIMADE).

Nesse período, pude perceber a importância da atuação do diretor escolar para a mobilização de sua equipe quando da necessidade de implementação de novas políticas públicas. Também se tornou perceptível a influência da subjetividade dos sujeitos na implementação de uma política pública, bem como a variabilidade de entendimento sobre aquilo que propunham os sistemas de gestão (controle, agilidade nos procedimentos, instrumento para a gestão, etc.).

Essas experiências, vivenciadas no processo de implementação dos sistemas mencionados, fomentaram questões sobre o uso dos dados dos sistemas de gestão escolar, sobretudo devido à diversidade de contextos encontrados nas escolas e regiões do estado de Minas Gerais. Soma-se a essas experiências o meu contato com pesquisas que abordavam a questão dos sistemas de gestão escolar (ALMEIDA, 2005; CAMPOS \& CAMPOS, 2001; DEMIR, 2006) que concluíam que, mesmo com a possibilidade de maior produção e organização dos dados educacionais, ainda há uma carência de abordagem sistêmica sobre o uso dos dados dos sistemas de gestão escolar pelos atores das unidades de ensino e, também, uma carência de formação para análise e interpretação desses dados. Decidi então aprofundar o estudo sobre essa temática na rede de ensino com que mais tive contato durante minha atuação no CAEd, a rede estadual de Minas Gerais.

A presente pesquisa sobre o SIMADE visa compreender de que forma os dados são utilizados e se o sistema é percebido e efetivamente usado como

\footnotetext{
${ }^{1}$ Entre 2014 e 2016, atuei em cursos de formação lato e stricto sensu para professores, diretores escolares e técnicos das secretarias municipais e estaduais de educação.
} 
instrumento de gestão pelos atores escolares. A coleta de informações focaliza principalmente a atuação do diretor e do secretário escolar, para caracterizar e compreender a forma como eles utilizam os dados educacionais extraídos do SIMADE.

O ponto de partida desta pesquisa, discutido ao longo do próximo capítulo, procura situar o estudo no contexto da pesquisa educacional. Inicialmente discuto as avaliações em larga escala, especificamente o uso de seus dados no contexto escolar, para em seguida ressaltar a atuação dos diretores escolares tanto na mobilização da equipe escolar para o uso dos dados, bem como para promover maior eficiência e eficácia nas unidades de ensino. Apresento também como as avaliações em larga escala, a gestão e a autonomia do diretor, aliadas a proliferação de computadores e internet nas unidades de ensino forneceram o cenário necessário para a implementação de sistemas de gestão escolar. Exponho alguns resultados de estudos internacionais e nacionais sobre o uso de sistemas de gestão em escolas públicas e privadas, bem como o uso dos dados.

Por último, apresento, ainda no capítulo um, o sistema de gestão escolar denominado Sistema Mineiro de Administração Escolar (SIMADE) como política pública e sistema de gestão implementado nas escolas da rede pública estadual de Minas Gerais. Como política pública, traz-se à tona o desenho da política pública do SIMADE e sua implementação com base nos relatos e resultados encontrados em uma etapa inicial de incursões exploratórias de pesquisa. Apresentamos também o SIMADE como sistema de gestão escolar, ou seja, a organização dos dados educacionais, usuários, estrutura dos menus e seus dados.

No capítulo 2 tratamos de descrever o problema, as hipóteses, as questões e os objetivos desta pesquisa, bem como o caminho metodológico adotado para sua consecução. Expomos também os procedimentos de aplicação e os ajustes necessários nos questionários do diretor e secretário detectados como pré-teste nas unidades de ensino da rede municipal de Juiz de Fora. Em seguida, a partir dos resultados do pré-teste, apresentamos o referencial teórico complementar utilizado para a elaboração dos questionários das escolas estaduais de Minas Gerais e descrevemos o processo de aplicação do survey nas escolas da rede estadual mineira.

No capítulo 3, dedicado aos resultados da pesquisa, apresentamos, a partir dos dados coletados no Censo Escolar de 2016, Prova Brasil de 2015 e nos 
questionários de diretor e secretário, as características das escolas, dos sujeitos (diretores, secretários/ATBs), da infraestrutura tecnológica (computadores, acesso ao SIMADE, usabilidade do sistema, etc.). Em seguida, no capítulo 4, a partir das respostas dos gestores da rede pública estadual de Minas Gerais construiu-se um indicador de autoeficácia dos diretores que os agrupou em três níveis: baixa autoeficácia; autoeficácia adaptativa; e alta autoeficácia. Analisamos algumas características do cotidiano do diretor, o uso do sistema e o SIMADE como instrumento para a gestão com o indicador de autoeficácia. Por fim, no capítulo 5, apresentamos algumas considerações e discutimos os limites da pesquisa e possibilidades para futuros estudos. 


\section{SITUANDO O OBJETO NO CONTEXTO DA PESQUISA EDUCACIONAL: sistemas de gestão escolar e o SIMADE.}

Na primeira metade do século XX, atribuía-se à escola papel central na construção de uma nova sociedade, justa e democrática, supondo que o acesso à escola pública e gratuita garantiria a igualdade de oportunidades educacionais e sociais. Nessa perspectiva, os indivíduos competiriam em condições iguais no sistema de ensino. Todavia, a democratização do acesso à educação e o prolongamento da escolaridade obrigatória após a segunda guerra mundial e as pesquisas sobre a escolarização em diferentes contextos e países tornaram evidente o problema das desigualdades educacionais entre os grupos sociais (BONAMINO et al., 2010).

Nos anos de 1950 e 1960, a constituição da Sociologia da Educação como campo de pesquisa foi norteada pelo "otimismo educativista e desenvolvimentista, que via na educação uma alavanca do desenvolvimento econômico e social (...) [e pela] preocupação constante com a equalização das oportunidades escolares" (NOGUEIRA, 1995, p.52). Amplos levantamentos de dados sobre os sistemas de ensino foram realizados, nos Estados Unidos, com o Equality of Educational Opportunity, conhecido como Relatório Coleman; na Grã-Bretanha, em 1967, com o Relatório Plowden; e, na França, entre 1962 e 1972, com pesquisa conduzida pelo Instituto Nacional de Estudos Demográficos (INED).

Esses países foram os pioneiros a produzir pesquisas tendo como objeto, especificamente, o público escolar, suas características e os fatores sociais e educacionais que influenciam o desempenho dos estudantes (NOGUEIRA, 1990; 1995). Esses grandes levantamentos de informações constataram que "as desigualdades no desempenho dos alunos estariam mais fortemente correlacionadas com suas diferentes origens sociais e familiares do que com as diferenças pedagógicas e de infraestrutura existentes entre as escolas" (BONAMINO, 2012, p. 119). As pesquisas apontaram, também, a desigualdade de acesso à escola e o seu agravamento à medida que o aluno avançava na sua trajetória educacional (BONAMINO, 2012).

Nas décadas seguintes, diversos estudos identificaram problemas nas análises presentes no Relatório Coleman, Relatório Plowden e nas pesquisas do INED, sendo a principal crítica a não observância do que acontecia nos processos 
internos à escola. Mesmo reconhecendo a relevância dos antecedentes sociais e econômicos para a explicação dos resultados escolares dos estudantes, as pesquisas se propuseram a mostrar que as unidades de ensino não podiam ser tratadas como se fossem todas iguais (BROOKE \& SOARES, 2008; BONAMINO, 2012).

Dessa forma, desde a década de 1970, os pesquisadores começaram a questionar a ideia consolidada pelas pesquisas mencionadas anteriormente, de que as escolas não fazem diferença e decidiram "olhar" para dentro das instituições educacionais. Diferenças significativas de desempenho de alunos com origem familiar semelhante e que frequentavam unidades de ensino diferentes atestaram a capacidade diferenciada das escolas para garantir o sucesso dos discentes, impulsionando novas pesquisas para identificar as causas desses resultados (BONAMINO, 2012).

Essa perspectiva de investigação é conhecida como pesquisa sobre eficácia escolar ou pesquisa sobre escolares eficazes, "e busca identificar e compreender as características das escolas e de seus processos internos que favorecem o melhor desempenho dos alunos" (BONAMINO, 2012, p. 120). Os estudos sobre eficácia escolar buscam determinar os efeitos das experiências vivenciadas na escola sobre a aprendizagem dos alunos. Controlando as características iniciais dos estudantes, como origem social, cor/raça, organização familiar, entre outras (ou seja, considerando alunos com níveis socioeconômicos similares), estas pesquisas buscaram medir quais fatores estruturais e organizacionais estavam vinculados aos diferentes resultados acadêmicos (BONAMINO, 2012).

A partir de então, as novas pesquisas constataram que o que acontece na escola faz, sim, diferença no desempenho do aluno, introduzindo o conceito de efeito escola. Segundo Brooke e Soares (2008), entende-se por esse efeito o quanto uma unidade de ensino, a partir de suas políticas e práticas internas, acrescenta ao aprendizado dos alunos. A partir disso, começou-se a focalizar a importância da escola para a compreensão do desempenho escolar dos discentes, mostrando que existem unidades de ensino que conseguem fazer com que o aluno aprenda mais do que o esperado para seus pares com mesma origem social desfavorável.

Sammons, Hillman e Mortimore (1995) ofereceram uma síntese da literatura sobre eficácia escolar, focalizando as características-chave que melhora descrevem 
as escolas bem-sucedidas. Essa síntese apresentou onze fatores ${ }^{2}$ frequentemente encontrados em escolas eficazes, dentre os quais destacamos o monitoramento do progresso que se desdobra em monitoramento do desempenho dos alunos e avaliação do desempenho da escola. De acordo com Reynolds e Teddlie (2008) ${ }^{3}$ :

mecanismos bem estabelecidos para o monitoramento do desempenho e progresso dos alunos, das salas de aula e da escola como um todo e dos programas de melhoramento são características importantes de muitas escolas eficazes. Esses procedimentos podem ser formais ou informais, mas de qualquer maneira eles contribuem para um foco no ensino e na aprendizagem e, frequentemente, desempenham um papel no aumento das expectativas e nos incentivos positivos (p. 370).

Por ser um elemento essencial no trabalho de uma escola eficaz o monitoramento permite determinar se os objetivos da unidade de ensino estão sendo atingidos; informar o planejamento, métodos de ensino e os resultados das avaliações internas e externas; e registrar o desenvolvimento acadêmico dos discentes. A incorporação do monitoramento ao cotidiano das escolas pode assegurar que as informações sejam usadas ativamente para se realizar uma avaliação minuciosa do desempenho e rendimento discente e também da própria escola (REYNOLDS \& TEDDLIE, 2008).

No contexto internacional de investigação em Sociologia da Educação, houve, a partir dos anos de 1980, um crescente e especial interesse pela avaliação dos sistemas educacionais e escolas, sobretudo considerando a desigualdade educacional constatada em inúmeras pesquisas e conjunturas e as possibilidades abertas pelos estudos sobre eficácia escolar. Bonamino (2012) observa um movimento semelhante no Brasil a partir da década de 1990, quando passaram a ser produzidas informações em larga escala que "mostraram mais claramente o atendimento educacional oferecido à população e o seu peso sobre o desempenho dos alunos dentro do sistema escolar" (ibid, p. 15).

Com a consolidação dos sistemas de avaliação em larga escala a partir dos anos de 1990 no Brasil, especialmente o Sistema Nacional de Avaliação da Educação Básica (SAEB) e da Avaliação Nacional do Rendimento Escolar (ANRESC) a partir de 2005, mais conhecida como Prova Brasil, bem como o

\footnotetext{
${ }^{2}$ Liderança profissional; visão e metas compartilhadas; um ambiente de aprendizado; ensino com propósitos definidos; altas expectativas; reforço positivo; monitoramento do progresso; direitos e responsabilidades dos alunos; relacionamento família-escola; organização orientada à aprendizagem.

${ }^{3}$ Lançado originalmente em 2000.
} 
desenvolvimento concomitante de avaliações estaduais e municipais similares, verificou-se um progresso notável na coleta, na produção e na disponibilização de informações sobre os sistemas de ensino e escolas (nesse caso de 2005 em diante, quando a quase totalidade das escolas públicas brasileiras de ensino fundamental passaram a participar da Prova Brasil). Além disso, a aplicação (junto com os testes de proficiência) de questionários contextuais aos gestores, professores e alunos fornece elementos para compreensão das desigualdades educacionais e para a elaboração de indicadores educacionais, bem como informações sobre as características das escolas que influenciam o desempenho dos discentes (PONTES, 2015).

As avaliações em larga escala também subsidiaram a implementação de políticas públicas educacionais e a definição de ações, mediações e intervenções para solucionar os problemas identificados nos sistemas de ensino. Ainda contribuem para o monitoramento da qualidade educacional, além de colaborar para a melhoria da aprendizagem discente, fornecendo informações com potencial para orientar a gestão e as práticas pedagógicas (SANTOS, 2017). Ao mesmo tempo, aumentou-se nos sistemas de ensino a demanda pela utilização dos dados resultantes dessas avaliações externas.

Entretanto, essa função pedagógica das avaliações não parece ser bem compreendida e praticada, vez que, conforme observado por alguns autores em pesquisas qualitativas e mistas - qualitativa e quantitativa - (SILVA et. al., 2013; FONTANIVE, 2013; CERDEIRA et al, 2017), o uso dos dados das avaliações em larga escala não parece ter provocado, dentro das escolas, os efeitos esperados na qualidade e equidade da educação oferecida às crianças e jovens brasileiros, dadas as dificuldades dos agentes escolares em compreender esses dados e, consequentemente, utilizá-los em seu cotidiano na tomada de decisões fundamentadas em evidências fornecidas pelas avaliações em larga escala.

Em resumo, embora se tenha conquistado um "progressivo aperfeiçoamento do diagnóstico sobre os resultados alcançados pelas diversas redes de ensino e sua crescente divulgação pública, não se tem observado uma efetiva melhoria dos indicadores educacionais" (CRUZ, 2014, p. 18), uma vez que parece haver pouca validade consequencial no sentido do que os "efeitos que os resultados podem despertar no pensamento, nas atitudes e na ação dos diversos interessados" (SILVA, 2013, p. 2) no contexto escolar. Na esteira desse raciocínio, Santos (2017) afirma 
que parece não haver uso conceitual dos dados - "mudanças nos pensamentos, nas atitudes e nos conhecimentos" (SANTOS, 2017, p. 21) - e sequer instrumental "utilização direta dos resultados para a tomada de decisões" (SANTOS, 2017, p. 21) pelos agentes escolares.

Estudos internacionais, como os Pierce et al. (2014); Mandinach e Gummer (2015) e Marsh et al. (2010), que desenvolveram pesquisas quantitativas, observaram a existência de uma grande quantidade de dados provenientes dos resultados das avaliações em larga escala com os quais os profissionais da educação deveriam lidar, mas também uma lacuna na formação dos docentes e gestores para compreender e interpretar tais informações.

Parra e Matus (2016), em estudo qualitativo no qual apresentam os processos de uso dos dados desenvolvidos por escolas chilenas e os fatores que os condicionam, afirmam que as unidades de ensino deveriam produzir dados relacionados aos seus resultados, buscando ajustar suas rotinas a uma gestão capaz de gerar evidências, transformando seus resultados em ações com foco na aprendizagem discente. $\mathrm{O}$ uso dos dados se refere a uma "prática situada que envolve atividades individuais e grupais e que se desenvolve como parte da tarefa diária dos agentes educativos, seja no nível de sala de aula, da instituição de ensino, ou o nível da gestão central” (PARRA \& MATUS, 2016, p. 209 - tradução da autora). Esses autores ainda afirmam:

El uso de datos se ha posicionado como una difundida estrategia de mejora de la gestión de las instituciones escolares en múltiples políticas educativas alrededor del mundo, debido a los impactos positivos vinculados con la generación de conocimiento y aprendizaje institucional, y a los cambios en las prácticas docentes y mejora en los aprendizajes de los estudiantes (PARRA \& MATUS, 2016, p. 2010)

No Brasil, os efeitos gerados pelos dados das avaliações em larga escala, segundo Silva e Paes de Carvalho (2014), dependem das intenções e objetivos dos sistemas de ensino, das características e históricos da rede escolar, do perfil socioeconômico discente e do próprio sentido que adquirem tais ações ao longo do tempo para os atores envolvidos, que tomam as decisões no nível central. Pesquisas qualitativas, predominantes entre os estudos, têm observado que os resultados dessas avaliações podem desencadear, entre outras possibilidades, a indicação de alunos para recuperação, formação continuada para os atores escolares, composição 
de critérios para alocação de profissionais e enturmação ${ }^{4}$ de alunos, produção de materiais pedagógicos (CALDERÓN, 2017; CRUZ, 2014). Além disso, tais resultados poderiam contribuir para o monitoramento do desempenho discente ao indicar as lacunas do processo de ensino aprendizagem e fornecer indícios de como aprimorá-lo. O monitoramento, portanto, contribuiria para se compreender as reais necessidades dos alunos e elaborar estratégias para melhorar o rendimento e desempenho discente, sendo um elemento para a eficácia escolar (OLIVEIRA, 2013).

Em contrapartida, outras pesquisas observam que a falta de divulgação e circulação de informações nas redes de ensino (SILVA et al., 2013); pouco retorno dos resultados para as escolas (SUPOVITZ, 2012); formação incipiente em relação ao uso dos dados (CERDEIRA et al, 2017; FREITAS, 2013); relatórios em linguagem técnica (SANTOS, 2017); preparação para o testes que podem levar a um estreitamento do currículo (BONAMINO \& SOUZA, 2012), bem como a pouca orientação sobre como utilizar esses dados no planejamento escolar (BROOKE \& CUNHA, 2011) são fatores que podem afetar, distorcer ou mesmo obstaculizar o uso dos dados.

Inúmeras pesquisas (ALMEIDA \& NHOQUE, 2017; CARVALHO, 2009; BRASIL, 1995) também apontam que as avaliações em larga escala incorporam a lógica da Nova Gestão Pública, denominada no Brasil como modelo de gestão gerencial, na qual o Estado fortalece-se na função de promotor e regulador do desenvolvimento econômico e social, adotando a produtividade, eficiência e qualidade na prestação dos serviços públicos, trazendo para o contexto educacional maior regulação e a competitividade entre as escolas.

A Nova Gestão Pública defende a avaliação em larga escala como elemento essencial para a promoção e garantia da educação de qualidade, ao mesmo tempo em que se constitui como um mecanismo de regulação de metas, do financiamento da escola e em alguns casos até mesmo da remuneração dos profissionais da educação (OLIVEIRA, 2015). Segundo Oliveira (2015) o argumento central usado por essas políticas tem sido de "fornecer um indicador de qualidade do ensino que possa ser apropriado pela sociedade, a fim de permitir a mobilização dos diferentes

\footnotetext{
${ }^{4}$ Alocação de alunos nas turmas.
} 
agentes escolares para que as práticas sejam ajustadas com o objetivo de melhorar os resultados" (p. 640).

Segundo Cerdeira et al. (2017), há um aumento da cobrança por resultados nesse contexto, ao associar às avaliações em larga escala a criação de indicadores, como o Índice de Desenvolvimento da Educação Básica (IDEB) e a políticas de bonificação, como o pagamento aos docentes e gestores de escolas nas quais os alunos obtêm desempenho satisfatório nas avaliações em larga escala (FONTANIVE, 2013).

As pressões intensas da política de bonificação (CERDEIRA et al., 2017; FREITAS, 2013; BROOKE \& CUNHA, 2011), podem levar a práticas treinamentos, simulados, estreitamento do currículo, etc. - que buscam elevar rapidamente a pontuação nos testes, sem contribuir para a aprendizagem efetiva e redução das desigualdades educacionais embora, segundo Bauer et. al., (2015), tais práticas tenham sido desenvolvidas para induzir maior atenção aos resultados de desempenho dos alunos. Nesse sentido, o uso dos dados, além de contemplar a lógica de responsabilização dos agentes escolares pelos resultados alcançados pelos alunos, é parte fundamental da possibilidade de melhorar o desempenho discente, bem como de suas consequências em termos de reconhecimento ou sanção para a instituição de ensino (PARRA \& MATUS, 2016).

Ainda que divulgar e disseminar os resultados obtidos nas avaliações em larga escala seja de fundamental importância para fomentar a discussão a respeito da qualidade da educação, mesmo que considerando apenas a proficiência como indicador de qualidade, o que empobrece a discussão (GUSMÃO, 2013) - e até mesmo propiciar que as escolas tenham dados e informações para subsidiar a tomada de decisões, diversos estudos tem questionado a distância temporal entre a aplicação das avaliações em larga escala e a disponibilização de seus resultados. De acordo com Cerdeira et al. (2017) e Freitas (2013), em geral, quando o resultado é divulgado, turmas já foram recompostas, professores realocados e outros elementos da organização escolar igualmente alterados, de tal forma que os resultados não mais dizem respeito à configuração escolar vigente, dificultando sua utilização para o planejamento escolar e desmotivando os agentes escolares, para os quais sua utilidade deixaria de se justificar.

Dentro desse cenário, delega-se maior responsabilidade ao poder local para que acompanhe, avalie, coordene e planeje os resultados, aumentando, assim, a 
responsabilidade da escola (CARVALHO, 2009). Nesse contexto, os diretores escolares adquirem destaque, por um lado, por mobilizar os "demais profissionais em direção a um ensino-aprendizagem mais eficaz, através da articulação do planejamento, organização e acompanhamento/avaliação, que influenciam indiretamente o desempenho escolar dos alunos" (SOARES \& TEIXEIRA, 2006, p. 170), podendo utilizar, para tal, os dados das avaliações em larga escala.

Por outro lado, esses profissionais estão imersos na política educacional na perspectiva gerencial - "relacionada à capacidade de buscar eficiência, medir essa eficiência, dar transparência aos resultados obtidos" (TRIPODI, 2014, p. 110) - que os responsabiliza pela busca da excelência e produtividade das unidades de ensino (AUGUSTO, 2012). Ou seja, os diretores têm uma autonomia que limita sua atuação, pois mesmo sendo do tipo construída, desenvolvida em função dos objetivos coletivos da escola (BARROSO, 2006), ela é decretada por "normas e regras formais que [...] podem favorecer ou dificultar a "autonomia da escola" (BARROSO, 2006, p. 11).

Observa-se, portanto, que ocorre um aumento da responsabilidade dos gestores escolar pela eficiência e eficácia da unidade de ensino ao mesmo tempo em que se busca modernizar a direção para que o uso dos dados das avaliações em larga escala possa ser incorporado ao cotidiano da escola. Em paralelo a esse propósito, proliferava nos anos de 1990 e 2000 a distribuição de computadores e internet nas escolas, a partir de iniciativas do Ministério da Educação (MEC), que desenvolveu o ProInfo, o Proinfo Integrado (MARTINS \& FLORES, 2015) e o Programa Banda Larga nas Escolas (PBLE).

Diante desse cenário, e buscando acatar a modernização da gestão escolar e o uso de dados pelos agentes das unidades de ensino, estados e municípios adotaram softwares para a gestão escolar em busca de maior qualidade nos sistemas de ensino, e que também permitiam, diferentemente das avaliações em larga escala, um acompanhamento mais próximo do cotidiano, maior transparência das ações dos atores escolares, melhor controle das informações das práticas desenvolvidas nas unidades de ensino e o monitoramento dos resultados em tempo real. 


\subsection{Sistemas de gestão escolar: o que dizem as pesquisas}

As tecnologias da informação e comunicação (TIC) são capazes de promover informação, comunicação, interação e de colaborar para a construção de novos conhecimentos, principalmente a partir da difusão da internet, da evolução dos computadores e da inserção dos indivíduos na sociedade da informação. Para Belloni (2003) "as TICs permitem combinar a flexibilidade da interação humana (com relação à fixidez dos programas informáticos, por mais interativos que sejam) com a independência no tempo e do espaço, sem por isso perder velocidade" (2003, p. 51).

Em âmbito educacional, conforme observado por Vallin et al (2007, p. 91), as TIC "podem ser usadas para auxiliar a escola a organizar seus dados e informações, propiciando a produção de conhecimento pela comunidade escolar de forma mais sistematizada, gerando conhecimento a partir da própria realidade”. Também podem ser utilizadas para melhorar os serviços administrativos informações sobre alunos, professores e outros funcionários da unidade de ensino -, auxiliando no funcionamento eficiente da escola e facilitando a busca e a análise das informações sobre o processo de ensino e aprendizagem (ALONSO, 2007). Ademais podem auxiliar no planejamento estratégico ao propiciar a reflexão sobre "a realidade, as necessidades e as ações da organização de forma articulada com os condicionantes internos e externos e com os objetivos de curto, médio e longo prazo" (MIRANDA; MACHADO, 2013, p.5), facilitando identificar necessidades de mudanças, prioridades e os meios para efetivá-las.

Em âmbito internacional, pesquisas qualitativas como a de Setiawan et. al, (2015) e Kornelis e Ock (2014), que apresentam o desenvolvimento de uma arquitetura para um sistema de gestão escolar, destacam que a criação deste tipo de software deve estar adequada à regulação do sistema de ensino e ao padrão nacional de educação, além de ser necessário englobar os processos desenvolvidos dentro da escola. Pesquisas quantitativas (DEMIR, 2006) e qualitativas (BLAU \& PRESSER, 2013; CUNHA, 2013) investigam, nesta ordem, diretores de 98 escolas primárias que utilizam um software de gestão privado; a liderança exercida por 500 diretores de escolas públicas secundárias a fim de aumentar a eficácia da escola; e um estudo de caso de utilização de um sistema de gestão escolar em uma escola portuguesa. Tais pesquisas indicam a existência de uma grande quantidade de dados dento das 
unidades de ensino e constatam a importante contribuição dos sistemas de gestão para a escola, para a organização da unidade de ensino, para a transparência das informações internas, para a tomada de decisões baseadas em dados, para a gestão do tempo de realização das atividades, para a otimização dos processos administrativos e de monitoramento da aprendizagem.

No que concerne ao uso dos dados dos sistemas de gestão escolar, pesquisas têm apontado o uso para: (i) obter notas, frequência e estatísticas sobre os discentes (DEMIR, 2006); (ii) monitorar a implementação do currículo, do desempenho da aprendizagem, aumentar a interação entre alunos e professores e elevar o nível de envolvimento dos pais (BLAU \& PRESSER, 2013); (iii) facilitar a difusão de informações sobre os alunos, o apoio às reuniões escolares e agilizar a obtenção dos dados de turmas e de alunos (CUNHA, 2013). Os autores, assim como Roque e Costa (2007), percebem o uso dos dados dos sistemas de gestão escolar mais do que como um recurso, seria um instrumento de gestão, uma ferramenta essencial para o processo de tomada de decisão e controle das atividades realizadas na escola.

Em resumo, trata-se de sistemas que combinam a tarefa de gerenciar os processos instrucionais e as necessidades especiais da escola (DEMIR, 2006, tradução da autora), ou seja, sistemas de gestão escolar que usufruem de potencialidades de diferentes TICs - computador, internet, câmera, etc. -, buscando simplificar os procedimentos organizacionais, apoiar o planejamento, monitorar o rendimento discente e fornecer dados que auxiliem a tomada de decisões (SHAH, 2014; ALONSO, 2007).

Em contrapartida, Starkey e Eppel (2017), em uma pesquisa qualitativa sobre a influência da política educacional sobre o uso de dados de um sistema de gestão escolar, alerta sobre a carência de abordagem sistêmica e de coerência do uso dos dados pelos atores escolares, visto que muitas vezes os diretores escolares utilizam os dados para prestação de contas/responsabilização, porém gostariam de usá-los para a tomada de decisões. Segundo as autoras, isso ocorre por causa das próprias políticas educacionais, que adotam os princípios neoliberais de competição, responsabilização dos atores escolares, etc., fazendo com que os diretores se preocupem mais com dados voltados para prestação de contas do que com aqueles que lhes auxiliariam na tomada de decisões.

Além disso, Irving e Gan (2012), em pesquisa qualitativa que examina as práticas de escolas secundárias para coleta e uso dos dados para informar e melhorar 
o ensino/aprendizagem, afirmam que profissionais da educação podem se sentir usuários finais passivos, sem conseguir analisar e interpretar o dado como uma informação sobre o ensino-aprendizagem em sala de aula. Para os autores, "a ferramenta e a expertise são limitadas em termos de análise sistêmica de dados, isto é, uma análise que permita aos professores e diretores interpretar e fazer julgamentos que informam e mudam sua prática ${ }^{5 "}$ (IRVING \& GAN, 2012, p. 131 - tradução da autora).

Shah (2014), em um artigo que investiga o uso de sistemas de gestão escolar, afirma que os softwares armazenam dados dos discentes e docentes, auxiliando os gestores a determinar os objetivos da escola e a elaborar um planejamento estratégico. Porém, o autor ainda destaca que os sistemas de gestão podem ter seu uso limitado pela falta de: (i) confiança ou habilidade no uso do software; (ii) treinamento; (iii) apoio dos órgãos superiores; (iv) suporte técnico.

Em âmbito nacional, embora o uso do computador tenha ocorrido inicialmente nas secretarias das escolas (MORAN, 2003), ainda temos problemas associados à falta de pessoal técnico para apoio ao uso do equipamento, infraestrutura (suprimento de energia elétrica nem sempre adequado e acesso a internet insuficiente, intermitente ou com baixa velocidade) e inexistência e/ou capacitação inadequada para o uso das TIC (TAROUCO, 2016).

Além disso, a partir de levantamento nas bases de dados do Scientific Electronic Library Online (SciELO), no portal de Periódicos Eletrônicos de Psicologia (PePSIC) e no Sistema de Información Científica Redalyc Red de Revistas Científicas de América Latina y el Caribe, España y Portugal, realizados por meio da expressão "sistema de gestão escolar", constatamos que existem poucos estudos sobre esse tema vez que não foram encontrados artigos nessas bases.

Ampliando a busca para artigos publicados em periódicos, eventos na área de educação e tecnologia da informação, catálogo de teses e dissertações da Coordenação de Aperfeiçoamento de Pessoal de Nível Superior (CAPES), mantendo a expressão "sistema de gestão escolar", encontramos cinco artigos publicados no período de 2012 a 2018 (FREIRE \& BASTOS JÚNIOR, 2013; CAVALCANTE et al., 2016; GONZAGA \& HANSEN, 2016; COSTA JÚNIOR et. al, 2012; SPECK et al., 2018) e cinco dissertações defendidas no Brasil no

\footnotetext{
5 Tradução da autora.
} 
período de 2012 a 2018 (BALDUTI, 2017; TOMAZ, 2015; FONSECA, 2014; SALGADO, 2014; MARTINS, 2014). Em virtude da inserção dos computadores nas escolas, ampliação do acesso à internet e incorporação cada vez maior na perspectiva gerencialista na educação, com princípios de eficiência, eficácia e produtividade, era de se esperar um número bem maior de pesquisas sobre sistema de gestão escolar. Nesse sentido, a presente tese pretende colaborar para ampliar a discussão, refletindo, especialmente, sobre o uso dos dados dos sistemas de gestão escolar.

O primeiro texto encontrado (FREIRE \& BASTOS JÚNIOR, 2013) trata-se de um estudo quantitativo sobre a importância de um sistema de gestão escolar em três escolas privadas localizadas em Quixadá (CE); enquanto os dois seguintes, respectivamente, investigam a adoção de um sistema open source ${ }^{6}$ para a gestão de uma unidade de ensino particular em Paraíso do Tocantins (TO) através de uma pesquisa qualitativa e quantitativa e um estudo de caso que analisou como cinco unidades escolares municipais localizadas em Pereira Barreto e Sud Mennucci (SP) têm utilizado sistemas de gestão escolar e o modo como esse uso tem ou não contribuído para a melhoria da gestão escolar.

O artigo de Costa Júnior et al. (2012) com abordagem mista apresenta resultados de uma pesquisa exploratória referentes à implementação de um software de gestão educacional em escolas públicas municipais de Aracaju (SE). Speck et al. (2018), por sua vez, analisam a aplicação do software de gestão escolar i-Educar apontando a viabilidade de sua implementação na rede municipal de Palotina (PR).

As pesquisas (FREIRE \& BASTOS JÚNIOR, 2013; CAVALCANTE et al., 2016; GONZAGA \& HANSEN, 2016; COSTA JÚNIOR et. al, 2012; SPECK et al., 2018)concluem que os sistemas de gestão escolar são uma ferramenta para a tomada de decisões e para o melhor gerenciamento das atividades administrativas e pedagógicas, além de contribuir nas tarefas inerentes à gestão, fornecer dados para traçar metas e controlar a frequência e o desempenho discente.

No que concerne as cinco dissertações encontradas, todas foram defendidas no mestrado profissional em Gestão e Avaliação da Educação Pública da

6 Termo em inglês que significa código aberto. Refere-se ao código-fonte de um software, que pode ser adaptado para diferentes fins. 
UFJF/CAEd ${ }^{7}$ (BALDUTI, 2017 ; TOMAZ， 2015 ; FONSECA， 2014 ${ }^{10}$; SALGADO, 2014 ${ }^{11}$; MARTINS, 2014 ${ }^{12}$;), investigaram especificamente o SIMADE na rede pública estadual mineira, sendo que as três primeiras usaram metodologias mistas (qualitativa e quantitativa), e as demais utilizaram, respectivamente, abordagem quantitativa e qualitativa. Os resultados foram semelhantes, pois os sujeitos das pesquisas (diretores, secretários das escolas e profissionais das SREs) reconhecem o avanço no tratamento dos dados educacionais, a diminuição do tempo investido pela equipe da secretaria da escola - secretário e ATBs - no preenchimento dos dados educacionais e a importância dos relatórios e documentos extraídos do sistema.

Essas pesquisas também indicaram a necessidade de aprimoramento do SIMADE e de seus dados. Nesse aspecto, Martins (2014) e Tomaz (2015), elencam, respectivamente, o predomínio de uso mais técnico, em que os dados utilizados no cotidiano da escola são os obrigatórios - lançamento de notas e frequências - ou um uso mais estratégico - para o estabelecimento de metas de melhoria no rendimento dos alunos, na redução da distorção idade-série e evasão escolar.

Os sistemas padronizam os procedimentos que, quando executados, produzem informações para a gestão das escolas, buscando também criar e disponibilizar informação fiável, seletiva e oportuna, que apoie o processo de tomada de decisão (ROQUE \& COSTA, 2007; CORREIA \& ZIVIANI, 2015), ao usufruir da possibilidade de busca, recuperação, organização, seleção e avaliação da informação, bem como os recursos disponibilizados pelos hardwares e softwares - velocidade, imagem, áudio, etc. Todavia, Gonzaga e Hansen (2016) alertam que

7 Desde 2010 o mestrado profissional do CAEd é parceiro da SEE/MG possibilitando que professores, diretores, secretários e técnicos da secretaria se tornem mestres em Gestão e Avaliação da Educação Pública.

${ }^{8} \mathrm{O}$ objetivo desta dissertação foi descrever e analisar os fatores que dificultam a utilização do Sistema Mineiro de Administração Escolar (SIMADE) em sua integridade pelos usuários nas escolas da rede estadual de Minas Gerais.

${ }^{9}$ Esta dissertação objetiva analisar de forma criteriosa como o SIMADE pode ser utilizado para contribuir com o planejamento, execução e controle no âmbito da gestão escolar.

${ }^{10} \mathrm{O}$ objetivo desta pesquisa era analisar a implementação do SIMADE na SRE Ouro Preto e propor um plano de ação visando aprimorar a utilização do sistema pelos servidores das escolas no âmbito da regional.

${ }^{11}$ Esta dissertação analisa a gestão da informação por meio do Sistema Mineiro de Administração Escolar - SIMADE, a fim de compreender se a sua implementação proporcionou melhorias nos dados produzidos na rede estadual de educação em Minas Gerais.

${ }^{12}$ Esta dissertação é um estudo de caso com foco na gestão escolar e cujo objetivo foi analisar e comparar a implementação e utilização do Sistema Mineiro de Administração Escolar (SIMADE) em duas escolas estaduais no âmbito da SRE Coronel Fabriciano (MG). 
é a resistência em aceitar o software e o tempo despendido no preenchimento dos dados que podem interferir negativamente no uso do sistema. Costa Júnior et. al., (2012), por outro lado, assinalam a necessidade do investimento contínuo e de longo prazo na manutenção dos equipamentos para uso dos sistemas de gestão escolar.

As pesquisas nacionais não apresentam efetivamente o uso dos dados por parte dos agentes escolares, observando apenas algumas funcionalidades dos sistemas que são utilizados nas escolas - cadastro de alunos, pais e professores, consultas e geração de relatórios, folhas de pagamento, etc. (FREIRE \& BASTOS JÚNIOR, 2013); emissão de declarações, boletins, históricos escolares e controle dos dados dos alunos, registro de frequências e sistema de cálculo de notas (CAVALCANTE et al. 2016). A única exceção é o estudo de Gonzaga e Hansen (2016), que citam a geração de relatórios, tabelas e gráficos para tomada de decisões no planejamento, monitoramento e avaliação da unidade de ensino. Portanto, em âmbito nacional, parece que há uma compreensão equivocada do que são os dados do sistema, vez que as funcionalidades dos softwares são citadas como dados.

Considerando a escola como organização educativa, observamos alguns estudos (MENDONÇA \& VARVAKIS, 2018; TEIXEIRA \& VALENTIN, 2017; SILVA \& GOMES, 2015) que abordam o uso dos dados dentro das organizações. Tais pesquisas afirmam que, para filtrar o dado e transformá-lo em informação relevante, de tal forma que seu significado seja apropriado pelos sujeitos organizacionais visando à tomada de decisões e, posteriormente, o desenvolvimento de uma ação, é necessário repensar o que significa "ser/estar informado".

Diversos estudos indicam que buscar informações em ambientes organizacionais é um processo desafiador porque, para satisfazer uma necessidade informacional, é preciso que o indivíduo saiba gerir o conhecimento, ou seja, buscar, recuperar, organizar, selecionar, avaliar e usar a informação que se alinha aos objetivos, metas e estratégias da organização (MASSA et al., 2018; MIRANDA, 2016; VENTURA \& NASSIF, 2016; MORAES \& BARBOSA, 2015; CORREIA \& ZIVIANI, 2015; RODRIGUES \& BLATTMANN, 2014). Além disso, conforme observado por Mejia e Uribe (2015), a qualidade do resultado final de uma organização está associada aos processos realizados pelos indivíduos, o que remete à autoeficácia computacional - aqui compreendida como - "a crença de um indivíduo quanto à sua própria capacidade de manipular os softwares e as tarefas 
inerentes ao manuseio do computador" (GUIMARÃES \& ABBAD, 2015, p. 174), bem como aos recursos utilizados como fontes de informação e também à compreensão dos dados que estão disponíveis. Como afirmam Parra e Matus (2016), o uso dos dados é uma competência organizacional que se sustenta pelos propósitos e múltiplos significados que adquire na comunidade escolar, bem como no desenvolvimento de intervenções realizadas no cotidiano escolar.

Portanto, as pesquisas nacionais e internacionais apontam os pontos positivos e negativos do sistema de gestão escolar dentro das unidades de ensino. Porém, a maioria das pesquisas é qualitativa ou mista (qualitativa e quantitativa); investiga sistemas implementados em instituições escolares das redes municipal ou privada; seus sujeitos são diretores, coordenadores pedagógicos e/ou professor. Essa literatura, portanto, deixa lacunas que essa tese pretende preencher no que concerne à investigação do Sistema Mineiro de Administração Escolar (SIMADE), implementado gratuitamente na rede pública estadual; voltado para a equipe administrativa da escola - diretor, secretário e Assistente Técnico da Educação Básica (ATB) -; além de englobar todas as 3.644 escolas da rede pública estadual de ensino. Busca-se, portanto, diferentemente das pesquisas já citadas, compreender os comportamentos, ações e percepções de uma população.

\subsection{O Sistema Mineiro de Administração Escolar (SIMADE) como política pública}

Minas Gerais é o maior estado da região Sudeste em extensão territorial, sendo o segundo mais populoso - atrás apenas de São Paulo - com população estimada em 21.119.536 habitantes, segundo o IBGE (2017), sendo 85,3\% em área urbana e 14,7\% em área rural. Possui 853 municípios e em 91,4\% deles o Índice de Desenvolvimento Humano Municipal (IDHM) está entre alto e médio, posicionando o estado em $9^{\circ}$ lugar no ranking das unidades federativas brasileiras. Subordinadas à Secretaria Estadual de Educação estão 47 Superintendências Regionais de Ensino (SREs), 16.550 creches e escolas de educação básica com 4.658.750 alunos matriculados na rede estadual (CENSO, 2016). 
O programa de reforma administrativa do Estado, denominado Choque de Gestão $^{13}$, foi implementado no período compreendido entre 2003 e 2014, durante a gestão do Partido da Social Democracia Brasileira $\left(\mathrm{PSDB}^{14}\right)$, buscando "imprimir modernidade, transparência, agilidade e eficiência na gestão, adequando-a aos novos tempos" (TRIPODI, 2012, p. 38), além de superar o modelo burocrático de administração. Suas ações buscavam a otimização de processos e modernização de sistemas e a reestruturação do aparelho do Estado, valendo-se da avaliação de desempenho individual e institucional, a fim de melhorar a qualidade e reduzir gastos dos serviços públicos (DUARTE et al., 2016; AUGUSTO, 2013).

Para consecução dessas diretrizes na educação de Minas Gerais, foram realizados dois movimentos: (i) a reestruturação da Secretaria de Estado de Educação de Minas Gerais em quatro subsecretarias, quais sejam: a Subsecretaria de Administração do Serviço Educacional; a Subsecretaria de Desenvolvimento da Educação Básica; a Subsecretaria de Gestão de Recursos Humanos e a Subsecretaria de Informações e Tecnologias Educacionais; (ii) a instituição, por meio da Lei $\mathrm{n}^{\mathrm{o}}$. 17.600, de $1^{\mathrm{o}}$ de julho de 2008, do Acordo de Resultados, instrumento gerencial de pactuação de resultados para o alcance dos objetivos e metas expressos na agenda do governo, no sentido de obter mais eficácia ${ }^{15} \mathrm{e}$ eficiência ${ }^{16}$ nos serviços públicos. O Acordo de Resultados integra as políticas de descentralização, que atribuem poder de decisão e responsabilidades às instâncias intermediárias, Superintendências Regionais de Ensino ( $\left.\mathrm{SRE}^{17}\right)$ e locais, escolas, além de prever maior participação e responsabilização dos atores educacionais. Nesse contexto foi criado o Sistema Mineiro de Administração Escola (SIMADE).

\footnotetext{
${ }^{13}$ Em 2008, o programa passou a ser denominado Estado para Resultados e, em 2011, Gestão para a Cidadania.

14 Sendo dois mandatos do político Aécio Neves (2003-2006) e (2007-2010) e um do político Antônio Anastasia (2011-2014).

${ }^{15} \mathrm{Na}$ gestão do serviço público, o termo eficácia é uma medida normativa de alcance de resultados, se preocupando com os fins, com os objetivos a atingir. O termo eficácia, ao ser aplicado aos sistemas de ensino, denota o grau em que a unidade de ensino cumpre suas funções mediante a satisfação dos objetivos e metas fixados para ela (BROOKE, 2010).

$16 \mathrm{Na}$ gestão do serviço público, o termo eficiência é geralmente associado à produtividade, se referindo à obtenção do máximo rendimento com o mínimo de recursos. Nos sistemas de ensino, a eficiência está relacionada à ordem de recursos e custos, significando alcançar os resultados pretendidos com os menores custos possíveis (AUGUSTO, 2010).

17 Tem por finalidade "exercer em nível regional as ações de supervisão técnico-pedagógica, de orientação normativa, de cooperação, de articulação e de integração do Estado e Município, em consonância com as diretrizes e políticas educacionais (MINAS GERAIS, 2011).
} 
Em Minas Gerais, o SIMADE foi indicado como uma ferramenta que integrava a reforma gerencial promovida pelo Choque de Gestão, não apenas pelo seu potencial de gerar informações para todo o sistema - vida escolar de alunos, profissionais da escola, plano curricular, etc. -, mas também por se configurar como uma tentativa de racionalizar os gastos (TRIPODI, 2014). Durante a gestão do Partido da Social Democracia Brasileira (PSDB) - de 2003 a 2014 - ele foi considerado um instrumento que visava promover melhorias na gestão das escolas públicas (com o intuito de formar cidadãos e qualificar as pessoas para o mercado de trabalho (SANTANA et. al., 2013), embora sua criação, formulação, implementação e avaliação tenham ocorrido de modo semelhante a uma política pública. Na gestão do Partido dos Trabalhadores (PT) - 2015 a 2018 -, que abarca o período de realização desta pesquisa, o sistema passou a ser considerado pelos profissionais da SEE/MG e de $\mathrm{SRE}^{18}$ como uma política pública da rede estadual de ensino.

O conceito de política pública, como qualquer tentativa de delimitação, conta com diferentes definições. Souza (2003), ao buscar sintetizar as contribuições de diversos autores, apresenta como definição do termo, "colocar o governo em ação" e/ou analisar essa ação (variável independente) e, quando necessário, propor mudanças no rumo ou curso dessas ações (variável dependente) (SOUZA, 2003, p. 26). Höfling (2001, p. 31) entende política pública como o "Estado em ação", ou seja, "é o Estado implantando um projeto de governo, através de programas, de ações voltadas para setores específicos da sociedade". A autora ainda ressalta ser essencial observar, dentro das políticas públicas, as "questões de fundo", as quais apresentam as decisões tomadas, os caminhos da implementação traçados e os modelos de avaliação aplicados (HÖFLING, 2001).

Alguns autores (LIMA \& D’ASCENZI, 2013; LOTTA, 2014) chamam atenção para a divisão das políticas públicas em fases ou etapas, que comumente englobam: agenda, formulação, implementação e avaliação. Mesmo que nem sempre essas etapas estejam bem delimitadas, já que podem se misturar ou se sobrepor, segundo eles, a abordagem conhecida como "ciclo de políticas públicas" pode servir como um recurso útil para a compreensão do objeto.

\footnotetext{
${ }^{18}$ Constatado em conversas informações com a equipe da SEE/MG que monitora o SIMADE e com uma inspetora escolar que fiscaliza escolas da SRE de Juiz de Fora.
} 
Nessa perspectiva, a Agenda - que sustentou a criação do SIMADE configura a etapa da política pública em que determinados temas ganham relevância no debate público e são incluídos nas plataformas eleitorais de diferentes governos (CONDÉ, 2011). Tal agenda teve início em 2003. Nesse período, os discursos fundamentados muito difundidos nos preceitos gerenciais, que importaram princípios e práticas de gestão empresarial para a gestão pública, foram incorporados na proposição do Acordo de Resultados. Dentro dessa perspectiva gerencial, calcada nos valores da eficiência, eficácia, produtividade e do controle sobre resultados, considerava-se que a melhoria do desempenho dos discentes estaria diretamente associada à atribuição de uma maior responsabilidade aos profissionais da educação, em particular aos gestores escolares.

Na configuração da agenda que viabilizou o SIMADE como política, foram de extrema relevância alguns programas do governo federal, como o PROINFO e o PBLE. Desde a década de 1990, o governo federal vem implementando programas como o Proinfo Integrado, que ampliou algumas diretrizes postuladas pelo Programa Nacional de Informática na Educação (PROINFO), em vigor entre 1997 e 2007, que buscou a universalização da informática educativa na rede pública de ensino por meio do acesso a computadores e laboratórios de informática. Reestruturado em 2007, o PROINFO passou a ser denominado Programa Nacional de Tecnologia Educacional (PROINFO Integrado), lançado pelo decreto 6.300, e seu objetivo era acelerar o processo de inclusão digital e ampliar a utilização de outras tecnologias e mídias na educação (MARTINS \& FLORES, 2015; BASNIAK \& SOARES, 2014; ALMEIDA \& SILVA, 2011).

Em 2008 foi lançado, em âmbito federal, pelo Decreto $n^{\circ}$ 6.424, o Programa Banda Larga nas Escolas (PBLE), com o intuito de conectar as escolas da rede pública à internet através de recursos tecnológicos que propiciem qualidade, velocidade e serviços capazes de melhorar o nível do ensino público no Brasil (BRASIL, 2014). Já o Escolas em Rede do governo estadual de Minas Gerais, lançado em 2004, possibilitou que as unidades de ensino da rede estadual de Minas Gerais adquirissem infraestrutura tecnológica ao fornecer computadores, impressoras, notebooks e conexão com a internet, bem como a instalação de laboratórios e a oferta de capacitação da equipe escolar.

Consolidou-se assim a difusão das TICs na rede pública estadual de ensino, com a ampliação da oportunidade de acesso à internet e integração das escolas da 
rede pública estadual às novas tecnologias oferecidas por tais programas e projetos. Dadas estas condições, a SEE/ $\mathrm{MG}^{19}$, em parceria com o $\mathrm{CAEd} / \mathrm{UFJF}^{20}$, implementou em 2006 um projeto piloto em 445 escolas municipais e estaduais de Belo Horizonte, instalando nos computadores dessas escolas o sistema de gestão escolar denominado SisLAME. Essa experiência motivou a SEE/MG a, posteriormente, adaptar o sistema para ter uma versão própria, que poderia ser implantada em toda a rede estadual.

Em outras palavras, apesar da agenda para criação do SIMADE ter se iniciado em 2003, com a implantação do Acordo de Resultados, foram iniciativas como o PROINFO, o Projeto Escolas em Rede, e posteriormente o PROINFO Integrado além da experiência com o SisLAME - que tornaram viável a implementação do Sistema Mineiro de Administração Escolar (SIMADE), cujo objetivo é:

disponibilizar aos educadores de Minas Gerais um conjunto precioso e preciso de dados sobre o sistema educacional, possibilitando a elaboração de práticas e projetos que elevem a qualidade da educação oferecida às nossas crianças e jovens. É um sistema de informações estruturado em rede com dados e elementos sobre aspectos determinados do processo educativo e da gestão escolar (REVISTA SIMADE, 2008).

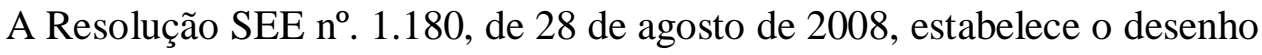
dessa política pública. A formalização do processo foi decisiva e definiu "o grau de centralização/descentralização, os mecanismos fiscalizatórios" (CONDÉ, 2011, p. 44). A formulação do SIMADE como política pública estabeleceu as diretrizes e orientou a implantação, a manutenção e a atualização dos dados, tornando obrigatória sua adoção para:

- Dotar a rede de ensino de sistema padronizado de gestão de processos administrativos e educacionais informatizados;

-Oferecer aos gestores educacionais e à sociedade mineira informações precisas, atualizadas e confiáveis sobre o sistema estadual de ensino;

-Facilitar a comunicação entre gestores, professores, demais servidores, pais e alunos das escolas estaduais e a unidade central e superintendências regionais de ensino (MINAS GERAIS, 2008).

A Resolução definiu, no artigo $6^{\circ}$, como "responsabilidade do Diretor da escola a entrada dos dados no SIMADE, a sua fidedignidade e a atualização

19 O CAEd foi o responsável por implantar o SisLAME em diversos municípios brasileiros. A SEE/MG apenas implementou um sistema que já existia.

${ }^{20}$ Centro de Políticas Públicas e Avaliação da Educação da Universidade Federal de Juiz de Fora (CAEd/UFJF). 
periódica". No parágrafo único do mesmo artigo, define que "a alteração de dados do SIMADE só poderá ser feita por servidor que tenha autorização expressa do Diretor da Escola" (MINAS GERAIS, 2008). A resolução, portanto, considera o papel do diretor como essencial na organização do trabalho escolar, liderando e coordenando a rotina das unidades de ensino (DRABACH \& SOUZA, 2014; SOARES \& TEIXEIRA, 2006) colocando "em ação os elementos do processo organizacional (planejamento, organização, avaliação) de forma integrada e articulada" (SOARES; TEIXEIRA, 2006, p. 157).

Vale destacar que a gestão escolar no ensino público de Minas Gerais só pode ser exercida por funcionários públicos - contratados ou efetivos - que participaram de um processo de Certificação Ocupacional ${ }^{21}$, estabelecido pelo Decreto Estadual no 44.871, de 7 de agosto de 2008, e pela Resolução SEE no $1.812^{22}$, republicada em 15 de abril de 2011, visando selecionar profissionais da educação para assumir o cargo de diretor ou de vice-diretor das escolas estaduais. Dessa forma, "estando legalmente investido em um cargo público, o diretor escolar cumpre um papel administrativo que o vincula tanto ao Poder que o nomeou quanto à instituição que dirige e representa" (OLIVEIRA, 2015, p. 43), fazendo a interlocução entre o Estado e a comunidade no entorno da escola.

Os diretores e vice-diretores, com carga horária de 40h e 30h, respectivamente, são os responsáveis por representar oficialmente a escola, pela função de coordenação político-pedagógica e institucional (administrativa e representativa da unidade de ensino), e têm por "tarefa primordial coordenar a gestão escolar, representar a instituição, responder administrativa e politicamente, zelar, dar suporte e fazer cumprir os objetivos pedagógicos da escola" (SOUZA \& GOUVEIA, 2010, p. 175).

Entretanto, é na etapa de implementação que os diretores, junto com secretários e ATBs, materializam as concepções teóricas que permeiam as intenções

\footnotetext{
${ }^{21} \mathrm{O}$ objetivo de cada certificação, regida por um edital específico que determina as normas de todo o processo, é credenciar professores ou especialistas em Educação Básica - supervisores escolares, -, efetivos ou contratados para exercer a função de diretor escolar. Por meio de prova, a certificação ocupacional busca avaliar o conhecimento pedagógico, técnico e as competências necessárias ao desempenho do cargo de diretor de escola estadual. O credenciamento obtido tem validade de quatro anos e se constitui como pré-requisito para o processo de escolha do diretor, vez que ainda há a composição das chapas - diretor e vice-diretor - em cada escola e escolha pela comunidade - alunos, pais e funcionários da escola. A escolha ocorre por meio de um processo de eleição para a função, sendo a chapa eleita nomeada pelo governo para cargos de comissão (DUARTE et al., 2016; MINAS GERAIS, 2015).

${ }^{22}$ Publicada pela primeira vez em 22 de março de 2011.
} 
dos formuladores. É na implementação que a política pública se torna uma experiência real, onde se executam as decisões adotadas em sua formulação (LIMA \& D’ASCENZI, 2013). Segundo Condé (2011), “é o momento onde, colocada em confronto com a realidade, a política pública enfrenta constrangimentos burocráticos, administrativos, institucionais ou econômicos que podem gerar obstáculos" (CONDÉ, 2011, p. 44).

Mesmo a resolução SEE $n^{\circ}$. 1.180 tendo definido que é de responsabilidade do diretor a entrada dos dados no SIMADE, bem como a sua fidedignidade e a sua atualização periódica dos dados do sistema (Resolução 1180/2008), na implementação, essa atribuição foi quase sempre compartilhada ou delegada para os secretários escolares e Assistente Técnico de Educação Básica (ATBs) devido à participação desses profissionais nas tarefas administrativas da escola (BALDUTI, 2017). Tanto secretários quanto ATBs atuam no processo de administração, organização e registro de documentos e dados sobre a vida escolar do aluno e a vida funcional dos servidores, além da otimização de procedimentos, ratificando o valor legal das ações administrativas e pedagógicas da escola.

O cargo de secretário, segundo dados da SEE/MG, deve ser ocupado por profissional efetivo ${ }^{23}$ - professor, ATBs ou supervisor escolar ${ }^{24}$-, que seja indicado pelo diretor da escola. Trata-se, portanto, de um servidor efetivo em exercício de cargo em comissão de secretário escolar. Ele é responsável por planejar, coordenar e executar as ações da secretaria da escola; organização e preservação de toda a documentação de forma escrita ou digitalizada; e responder por suas imputações de modo a assegurar o mais perfeito e regular desenvolvimento dos trabalhos administrativos, dentro dos prazos estabelecidos pela gestão, SRE ou pela SEE/MG (MINAS GERAIS, 2004). Cabe assinalar que os Secretários escolares respondem administrativamente e legalmente pela escola, junto com o diretor, e pela documentação da unidade de ensino (ALMEIDA et al., 2013; SIMÃO \& NETTO, 2008).

\footnotetext{
${ }^{23}$ Como o secretário escolar pode optar por manter o vencimento da função de origem ou receber como secretário, não se pode definir um valor inicial de pagamento.

${ }^{24}$ Trabalha 24 horas semanais e é responsável por coordenar o processo de construção coletiva e execução da proposta pedagógica da escola; zelar pelo cumprimento do plano de trabalho dos docentes, coordenar as reuniões do conselho de classe e prestar atendimento à comunidade escolar em relação ao processo de ensino aprendizagem.
} 
O secretário dispõe de um ou mais ATBs - definido de acordo com a quantidade de matrículas da unidade de ensino, turmas e etapas atendidas pelas escolas -, que são profissionais efetivos ou contratados para trabalhar $30 \mathrm{~h}$ na secretaria da escola. A escolarização mínima exigida para exercer a função de ATB é o ensino médio técnico. O ATB é subordinado ao secretário escolar e o auxilia a executar as tarefas da secretaria, como atender ao público, registrar os resultados escolares, prezar pela vida funcional dos servidores da escola, etc. É um apoio técnico ao secretário escolar, um auxiliar na secretaria (MINAS GERAIS, 2011).

Portanto, o secretário e o ATB são mais do que meros executores de tarefas burocráticas, e sim profissionais que lidam diariamente com os dados e legislações da escola. Trata-se de profissionais que muitas vezes são a "ponte" entre os que tomam decisões - diretores - e os que executam tais decisões - supervisor escolar, professores, etc. (ABUD, 2012).

Buscando compreender a implementação desta política, apresento o resultado de uma pesquisa interna realizada pelo CAEd em 2010, da qual participei por, na época, ser analista de implementação do SIMADE. Também apresento o resultado de duas incursões de pesquisa exploratórias ${ }^{25}$ desenvolvidas por mim em 2015 e 2016, com intuito de sistematizar e integrar informações já existentes sobre o sistema, inclusive aquelas que eu já possuía de forma mais ou menos intuitiva e dispersa a partir de minha experiência de trabalho no CAEd, que muitas vezes envolveu a implementação do SIMADE.

Como o SIMADE é uma política pública que envolve a utilização de um software, o CAEd desenvolveu e aplicou um questionário ${ }^{26}$ com intuito de avaliar a qualidade do sistema acerca da percepção dos usuários das escolas. A qualidade do software pode ser definida como "a totalidade de características de um produto de software que lhe confere a capacidade de satisfazer necessidades explícitas e implícitas” (ISO 9126, 2010, s/p). Em outras palavras, são as características do software que devem satisfazer às necessidades explícitas, ou seja, condições e objetivos referentes ao processo de desenvolvimento do produto, e implícitas, isto

\footnotetext{
25 Realizada quando o pesquisador não tem uma questão de pesquisa bem definida, podendo ocasionar a ausência de hipóteses.

${ }^{26} \mathrm{Na}$ ocasião eu ainda fazia parte da equipe do SIMADE, atuando como analista na Equipe de Suporte, e colaborei para a elaboração do questionário.
} 
é, a qualidade em uso, que deve permitir aos usuários atingir metas com segurança e satisfação em um contexto de uso específico (GOMES, 2013).

A avaliação foi realizada a partir de atributos da qualidade de software, já indicadas em algumas pesquisas (CAMPOS \& CAMPOS, 2001; GOMES, 2013), bem como pela Norma ISO 9126 ${ }^{27}$. Em avaliações similares, tais atributos geralmente são distribuídos em seis categorias, quais sejam: funcionalidade, confiabilidade, usabilidade, eficiência, manutenibilidade ${ }^{28}$ e portabilidade $^{29}$.

Abrangendo apenas as quatro primeiras categorias (porque o intuito era captar a percepção dos usuários sobre a qualidade do SIMADE e não verificar questões técnicas, o questionário do $\mathrm{CAED}^{30}$ ) foi respondido por 276 servidores públicos, sendo 165 ATBs, 73 secretários e 38 profissionais com outras funções dentro da escola.

A primeira categoria é a Funcionalidade, que se refere "a capacidade de um software prover funcionalidades que satisfaçam o usuário em suas necessidades declaradas e implícitas, dentro de um determinado contexto de uso" (ISO 9126, 2010, s/p). Nessa categoria, cerca de $70 \%$ dos respondentes destacaram as funcionalidades de cadastro de aluno, matrícula de aluno e enturmação (alocação de um aluno em uma turma). Tais respostas mostraram que o SIMADE satisfazia às necessidades básicas dos usuários, já que os passos iniciais para inserir as informações sobre os alunos constituem, exatamente, nessas três funcionalidades. No entanto, funcionalidades como Avaliação (que corresponde ao lançamento de nota e frequência) e Histórico (que traz as disciplinas, as notas e a frequência de todos os anos já cursados pelos estudantes) contavam apenas com 23\% e 14\%, respectivamente, de utilização. Esse resultado pareceu indicar que os usuários apresentavam dificuldades na utilização de tais funcionalidades ou que essas não satisfaziam suas necessidades.

A confiabilidade se refere à capacidade de o software se manter em um determinado nível de desempenho dentro das condições estabelecidas, ou seja, manter o funcionamento adequado mesmo quando ocorre alguma falha (ISO 9126,

\footnotetext{
${ }^{27}$ Define um conjunto de parâmetros para padronização da avaliação da qualidade de software e esteve vigente entre 2003 e 2010.

${ }^{28}$ Refere-se à facilidade de modificação do sistema.

${ }^{29}$ Refere-se à facilidade de adaptação do sistema em diferentes ambientes.

${ }^{30} \mathrm{O}$ envio do questionário foi realizado por e-mail pela Equipe de Suporte do SIMADE e as respostas armazenadas em um banco de dados do CAEd.
} 
2010). Ao serem questionados se a mensagem de erro $^{31}$ era clara e se ajudava a solucionar os problemas, respectivamente, $50 \%$ e $65 \%$ consideravam que não, indicando que o SIMADE, ao apresentar erros ${ }^{32}$, impossibilitava a continuidade da tarefa desenvolvida pelo usuário.

A usabilidade se refere à "capacidade do software ser compreendido, seu funcionamento aprendido, ser operado e ser atraente ao usuário" (ISO 9126, 2010, s/p), ou seja, à facilidade de uso. Para Costa e Ramalho (2010), se o programa não tiver uma boa usabilidade, estará destinado ao fracasso, mesmo que suas funções sejam valiosas para os usuários. Nessa categoria, as questões que compuseram o questionário versavam sobre a existência, no SIMADE, de: apresentação agradável, tamanho das letras adequado, ícones e botões fáceis de utilizar, informações encontradas com facilidade e textos claros e objetivos. A tabela a seguir apresenta as respostas:

Tabela 1: Usabilidade do SIMADE

\begin{tabular}{lccc}
\hline \multicolumn{1}{c}{ Questões } & \multicolumn{2}{c}{ Respostas } \\
\hline O SIMADE tem uma apresentação agradável? & $88,0 \%$ & $10,8 \%$ & $1,0 \%$ \\
A forma e o tamanho das letras são adequados? & $92,0 \%$ & $7,6 \%$ & $0,36 \%$ \\
Os ícones/botões são fáceis de utilizar? & $79,7 \%$ & $19,9 \%$ & $0,36 \%$ \\
Você encontra as informações com facilidade? & $53,6 \%$ & $46,0 \%$ & $0,36 \%$ \\
Os textos do SIMADE WEB são claros e objetivos? & $62,6 \%$ & $36,5 \%$ & $0,72 \%$ \\
\hline
\end{tabular}

Fonte: Elaborado pela autora a partir do Survey CAED 2010.

Na percepção dos usuários, a usabilidade do SIMADE apresentava aspectos positivos, já que mais de $50 \%$ dos usuários responderam de forma afirmativa todas as questões. No entanto, as questões sobre a facilidade de acesso às informações e a presença de textos claros e objetivos nos recursos do sistema - menus, botões, ícones, funcionalidades, documentos impressos, etc. -, mostraram a necessidade de tais categorias serem repensadas, pois as respostas evidenciaram uma insatisfação com os recursos. Em relação à eficiência, aqui compreendida como o "tempo de

\footnotetext{
${ }^{31}$ Todas as vezes que o sistema parava de funcionar, ou quando algo inesperado acontecia, uma mensagem de erro era exibia. As mensagens de erro, apresentadas em forma de código, indicavam uma falha na execução do SIMADE. Entretanto, para os usuários, a mensagem era pouco explicativa, vez que eles não compreendiam tal codificação.

${ }^{32}$ Exemplos de erro que geralmente aconteciam: HTTP 5000 - Internal Server Erro, que significava que a página não podia ser exibida devido a um erro interno do servidor; SIMADEWEB - Erro no processamento, que significa que ocorreu um erro inesperado durante o processamento de uma informação.
} 
execução e (se) os recursos envolvidos são compatíveis com o nível de desempenho do software" (ISO, 2010, s/p), na opinião dos usuários, tratava-se de uma limitação do sistema: para $88,4 \%$, o SIMADE não executava as tarefas rapidamente, mesmo que, na maioria das escolas, $95 \%$ a internet fosse banda larga ${ }^{33}$.

Portanto, a despeito de o SIMADE apresentar uma interface agradável, ele deixava a desejar no que se refere à execução das tarefas e às mensagens de erro. Fica a hipótese de que as mensagens de erro sejam compreensíveis apenas para os desenvolvedores, em detrimento dos usuários finais. Os resultados dessa incursão exploratória fomentaram novos questionamentos para a pesquisa atual sobre a usabilidade do sistema, as características dos respondentes e das escolas, bem como sobre o nível de conhecimento que os usuários têm em relação ao sistema.

Em 2015, fiz uma pesquisa exploratória em quatro escolas estaduais de anos iniciais do Ensino Fundamental situadas em distintas regiões da cidade de Juiz de Fora. O intuito era compreender se os inspetores escolares - que atuam na SRE de Juiz de Fora e são responsáveis por supervisionar pedagógica e administrativamente as escolas -, diretores das unidades de ensino e os profissionais da secretaria escolar - secretários e ATBs -, reconheciam o SIMADE como uma ferramenta administrativa ou pedagógica para a gestão das escolas já que desde 2010, ano da incursão exploratória realizada pelo CAEd, o sistema havia sido aperfeiçoado para fornecer mais funcionalidades que facilitassem a organização administrativa e pedagógica da escola.

$\mathrm{Na}$ ocasião apliquei presencialmente três questionários, um para cada profissional mencionado anteriormente, totalizando doze instrumentos respondidos (quatro de diretor, quatro de secretário escolar e dois de ATB e duas inspetoras). Constatei que diretores e secretários escolares identificavam o SIMADE, prioritariamente, como uma ferramenta de gestão administrativa da escola. Por outro lado, para as inspetoras das escolas, que atuavam na Superintendência Regional de Ensino de Juiz de Fora, o SIMADE era um instrumento de gestão administrativa e pedagógica.

Considerando a justificativa da proposição da política, como ferramenta para viabilizar “... a elaboração de práticas e projetos que elevem a qualidade da educação oferecida às nossas crianças e jovens" (CAEd, 2008, s/p), pode-se afirmar

\footnotetext{
${ }^{33}$ Conexão da internet que permite ao usuário navegar em alta velocidade.
} 
que existe uma infidelidade normativa, já que, para a escola, a partir da "fidelidade dos atores aos seus objetivos, interesses e estratégias" (LIMA, 2011, p. 70), o SIMADE era utilizado apenas para a organização burocrática - execução das leis e dos regulamentos educacionais estabelecidos em Minas Gerais -, ou seja, como um instrumento administrativo da escola. Entretanto, seu potencial pedagógico, não fica claro na resolução que estabelece suas diretrizes e orientações quanto a manutenção e atualização dos dados, permitindo que a escola faça uma interpretação mais administrativa do sistema, usando-o para controle e comunicação com a SRE e SEE/MG, enquanto as inspetoras reconhecem sua utilidade para os aspectos voltados para o ensino e aprendizagem discente.

$\mathrm{Na}$ incursão exploratória de 2016, buscamos, a partir de nove entrevistas com integrantes do CAEd e de duas SREs, compreender como a implementação do SIMADE foi desenvolvida. Foram, então, entrevistados o coordenador geral (responsável por gerenciar toda a implementação); um dos nove supervisores de implementação (que coordenavam a implementação em todo o Estado de Minas Gerais); dois dos 56 instrutores (responsáveis por instalar o sistema nas unidades de ensino e ministrar o treinamento para os agentes escolares); três analistas do CAEd (que trabalharam como suporte técnico aos supervisores e instrutores); e dois analistas de SRE (que acompanharam a implementação a partir da perspectiva das SREs, órgãos intermediários da SEE/MG).

De acordo com os dados levantados nessa incursão exploratória, a implementação do SIMADE nas $3920^{34}$ escolas de Minas Gerais, distribuídas nas seis regiões do Estado, ocorreu entre janeiro de 2008 e março de 2010, com a participação de integrantes do CAEd, responsáveis pelos treinamentos ministrados para a equipe escolar. Esse treinamento, posteriormente, ficou sob a responsabilidade dos técnicos das Superintendências Regionais de Ensino (SRE). No entanto, os desafios enfrentados em todo o estado foram os mesmos, de acordo com informações dos nove entrevistados: (i) resistência à utilização do SIMADE; (ii) usuários com pouca familiaridade com as TICs; (iii) utilização de outro sistema de gestão ${ }^{35}$; (iv) infraestrutura precária das escolas; (v) instrutores sem

\footnotetext{
${ }^{34}$ Total de escolas da rede pública estadual mineira no ano de 2008.

${ }^{35}$ Algumas escolas adquiriam com recurso próprio outro sistema de gestão, como o Consult SAE, o Colégio, etc - que possuíam funcionalidades semelhantes ao SIMADE, como por exemplo, cadastro, matrícula, enturmação, lançamento de notas e frequência.
} 
conhecimento sobre a legislação educacional; (vi) menus e funcionalidades com nomes pouco usuais; (vii) a resolução ${ }^{36}$ que orientava a instalação e uso do SIMADE só foi lançada oito meses após o início da implementação; (viii) comprometimento variado dos técnicos das SREs com a implementação, já que, em um segundo momento, eles foram os responsáveis por repassar os treinamentos; (ix) necessidade de internet nas escolas para a versão WEB do SIMADE.

Como vantagens foram citadas a migração dos dados do SIMADE para o Censo Escolar e um software de elaboração de relatórios denominado Business Inteligence (BI), que, inicialmente, foi proposto para elaborar os indicadores educacionais de Minas Gerais ${ }^{37}$. O BI foi utilizado até setembro de 2016, extraindo informações do banco de dados do SIMADE para a elaboração de relatórios conforme solicitações da $\mathrm{SEE} / \mathrm{MG}^{38}$. Os relatórios eram gerados no formato HTML $^{39}$, no padrão de uma planilha em Excel, para que a SEE/MG pudesse trabalhar com a informação e realizar novos cruzamentos dos dados.

Em outubro de 2016, o SIMADE passou a ser administrado somente pela SEE/MG, embora até dezembro do mesmo ano o CAEd ainda fosse responsável pelo suporte ${ }^{40}$ aos usuários do sistema. Em janeiro de 2017 o SIMADE se tornou responsabilidade exclusiva da SEE/MG e o atendimento aos usuários passou a ser realizado pelas equipes das SREs.

\subsubsection{SIMADE como política pública: atores escolares}

Nas escolas não há um modelo exclusivo de organização, pois as unidades escolares apresentam um modo de funcionamento em que "ora se ligam objectivos, estruturas, recursos e actividades e se é fiel às normas burocráticas, ora se promove a sua separação e se reproduzem regras alternativas; ora se respeita a conexão normativa, ora se rompe com ela e se promove a desconexão de facto" (LIMA,

\footnotetext{
36 Trata-se da Resolução SEE nº 1.180 , de 28 de agosto de 2008, que definiu como obrigatória a utilização do SIMADE nas escolas públicas da rede estadual de Minas Gerais. A implementação começou em janeiro de 2008 e a resolução só foi lançada em agosto daquele ano.

${ }^{37} \mathrm{O}$ BI permite uma "melhor análise e compreensão da informação sob forma de relatórios, gráficos e cruzamento de dados, favorecendo tomadas de decisões melhores e mais assertivas" (CAEd, 2015b).

${ }^{38}$ Alunos por faixa etária, Número de Alunos de Atividade Complementar/AEE, etc.

39 HTML - abreviação para a expressão inglesa HyperText Markup Language, que significa Linguagem de Marcação de Hipertexto.

${ }^{40}$ Suporte telefônico, presencial e via e-mail.
} 
2011, p.47). Dessa forma, as regras da política pública são ressignificadas, sendo interpretadas sob a ótica dos profissionais da unidade de ensino, que não são apenas executores da orientação de uma gestão central (SILVA \& PAES DE CARVALHO, 2014).

Soma-se a isso o fato de diretores e secretários serem também burocratas do nível de rua, ou seja, "profissionais que estão na linha de frente do relacionamento com os usuários dos serviços públicos e cujo trabalho permite discricionariedade para deliberar sobre benefícios e sanções que os cidadãos podem receber nestes respectivos serviços" (FERREIRA \& LOTTA, 2013, p.4). Observar esses atores oferece importantes elementos para entender como exercem a discricionariedade e como os diversos fatores relacionais e institucionais influenciam em sua atuação e no uso dos dados do SIMADE.

Além disso, conforme observado por Russo e Azzi (2017), em artigo que trata da implementação de políticas públicas educacionais sob a perspectiva da Teoria Social Cognitiva, a subjetividade que os agentes escolares expressam na apropriação que fazem dos textos das políticas públicas filtrados pelos seus conhecimentos, experiências, valores e crenças, se torna uma fonte de imprevisibilidade quanto aos resultados da política.

É nesse âmbito que se coloca o conceito da autoeficácia ${ }^{41}$, que integra o escopo da Teoria Social Cognitiva ${ }^{42}$, a qual surgiu em 1977 e foi formulada eamplamente estudada pelo psicólogo Albert Bandura, e se refere à "crença ou a expectativa de que é possível, através do esforço pessoal, realizar com sucesso uma determinada tarefa e alcançar um resultado desejado" (NEVES \& FARIA, 2009, p. 208). Em virtude disso, a crença da autoeficácia, ainda segundo as autoras, se funda na noção de competência pessoal, pois é "essa noção que permite aos sujeitos estimar a possibilidade de realizarem as tarefas com sucesso e de alcançarem os resultados desejados, levando-os a formar expectativas para a sua realização" (NEVES \& FARIA, 2009, p. 208). A crença da autoeficácia enfatiza, portanto, a

\footnotetext{
${ }^{41}$ Além da autoeficácia do gestor, existem também, em relação às unidades de ensino, a autoeficácia coletiva da escola, do professor e do aluno.

${ }^{42}$ A Teoria Social Cognitiva propõe "um modelo explicativo que se desenha pelo determinismo recíproco, no qual comportamento, fatores pessoais e o ambiente operam interagindo como determinantes que se influenciam bidirecionalmente e que, no conjunto, formam o triângulo comportamento, fatores pessoais e ambiente" (AZZI, 2010, p. 253).
} 
avaliação daquilo que os sujeitos acreditam ser capazes de fazer com as capacidades e competências que possuem.

Dessa forma, a autoeficácia pode aumentar a probabilidade de sucesso na implementação das políticas públicas, uma vez que, a partir dela, o indivíduo é capaz "de se envolver e desenvolver determinada atividade, o que torna mais provável que ele anteveja resultados positivos e com isso consiga engajar-se de forma mais intensa com a atividade" (LIMA et al., 2016, p. 203). Não se trata apenas de conhecimento ou habilidade, mas sim de uma crença que pode atuar em direção a determinado objetivo e ao desempenho bem-sucedido de certas tarefas.

Portanto, os agentes executores da política pública SIMADE podem ou não criar ou participar de um cenário promissor para a utilização do sistema e para o uso de seus dados, uma vez que existe um universo de possíveis ações em que os indivíduos podem se engajar, e assim produzir certos resultados. Consequentemente, é possível pensar que os indivíduos possuem “crenças em suas capacidades em organizar e executar cursos de ação requeridos para produzir certas realizações“ (RUSSO, 2017, p. 129), ou seja, a autoeficácia para se autoorientar e dirigir seu comportamento para a excelência em sua atuação (PIEDADE \& PEDRO, 2014).

\subsubsection{Sistema Mineiro de Administração Escolar (SIMADE) como sistema de gestão}

O SIMADE, como sistema de gestão escolar, engloba as vantagens das TIC, ao obter "todas as informações sobre o sistema educacional mineiro, que facilita a elaboração de ações para elevar a qualidade da educação em Minas Gerais" (CAED, 2014, s/p), além de permitir acompanhamento em tempo real, por parte das SREs e SEE/MG, do trabalho desenvolvido dentro das escolas. Segundo a SEE/MG (2010), antes do SIMADE as informações das escolas e dos alunos ficavam disponíveis de forma segmentada, na escola ou na SRE a qual a escola pertencia, podendo chegar na SEE/MG uma informação incorreta ou obsoleta. Com a implantação do sistema, unificaram-se as informações das escolas e das SREs e, posteriormente, foram 
migrados os dados da escola, alunos, docentes, matrículas, turmas, rendimento e movimento escolar (abandono) para o Censo Escolar ${ }^{43}$.

A SEE/MG e as SREs possuem, respectivamente, acesso aos dados de todas as escolas estaduais e das unidades de ensino de sua jurisdição, através de logins e senhas que lhes permitem consultar e imprimir os dados das escolas, além de auxiliar e apoiar os profissionais da unidade de ensino no planejamento de ações e de distribuição de recursos, como, por exemplo, merenda e transporte escolar. A SRE, por ser o órgão intermediário entre a escola e a SEE/MG, ainda tem a incumbência de autorizar a abertura de novas turmas e validar a configuração do pacote componente ${ }^{44}$ e do pacote etapa ${ }^{45}$, além de aprovar a contratação de professores para atuar no Atendimento Educacional Especializado (AEE).

Dentro das escolas, o acesso ao SIMADE é realizado pela equipe diretiva diretor e vice-diretor - e da secretaria da escola - secretário e ATB -, com login e senha específicos para cada profissional. Aos diretores, cabe o cadastro de todos os secretários e ATBs, a realização da auditora - monitoramento das ações realizadas pelos demais usuários do sistema -; a validação de cadastro de alunos duplicados, ou seja, atestar que se trata de discentes diferentes ${ }^{46}$, além de auxiliar e acompanhar o preenchimento dos dados. Já a equipe da secretaria da escola fica incumbida de preencher os dados do sistema para garantir o seu funcionamento, além de atualizar as informações constantemente, pois serão migradas para o Censo Escolar. Dessa forma, cadastro de alunos, turmas, professores, programa pedagógico, etc., fazem parte de suas atribuições.

Em resumo, para a gestão escolar, o SIMADE se constitui como um sistema que organiza os dados educacionais, possibilitando monitorar o desempenho, o rendimento, a aprendizagem e a frequência discente. A partir de seus dados, é possível propor estratégias e/ou ações para melhorar a qualidade da educação

\footnotetext{
${ }^{43}$ É realizado anualmente nas escolas públicas e privadas que ofertam a Educação Básica (Educação Infantil, Ensino Fundamental e Ensino Médio), Educação Especial e Educação de Jovens e Adultos. Contém dados que constituem a mais completa fonte de informações do MEC para a formulação, monitoramento e avaliação de políticas públicas (INEP, 2016 d).

${ }^{44} \mathrm{O}$ pacote Componente configura cada disciplina, definindo a área de conhecimento, a forma de avaliação (nota, conceito ou sem avaliação), o valor total, se permite casas decimais, a quantidade de bimestres e o valor de cada um deles, e se possui divisão de recuperação.

${ }^{45}$ Configura o ano de ensino (a série), informando o tipo de ensino, o ano (a série), se permite progressão parcial e quais são as disciplinas.

${ }^{46}$ Eles validam no sistema, por exemplo, quando um aluno tem o mesmo nome, data de nascimento e nome da mãe idêntico a de outro discente, cabendo ao diretor averiguar se é o mesmo estudante e autorizar ou não a sua inserção no sistema.
} 
escolar. Para a secretaria da escola, o sistema auxilia na organização dos dados educacionais - cadastro, matrícula, enturmação, resultado final (aprovação, reprovação, dependência, evasão, abandono), etc. Ou seja, dentro das escolas, o SIMADE pode auxiliar no melhor desempenho da função dos secretários e ATBs, agilizando a parte da escrituração e armazenamento da informação, bem como auxiliar os diretores na gestão da unidade de ensino.

Desde 2016, com o SIMADE sob a responsabilidade apenas da SEE/MG, houve uma mudança de endereço ${ }^{47}$ para acessar o sistema; a introdução da Companhia de Tecnologia da Informação do Estado de Minas Gerais (PRODEMGE) como órgão do Estado de Minas Gerais responsável pela atualização e implementação de novas funcionalidades no sistema ${ }^{48}$; criação da página SIMADE Fácil, no Facebook, com o intuito de dar informes/comunicados, disponibilizar tutoriais, vídeos, decretos, resoluções, estabelecer prazos para a realização das atividades, como, por exemplo, migração dos dados para o Censo Escolar. A mudança mais significativa, entretanto, ocorreu em 2017, quando o sistema passou a ser integrado ao Diário Escolar Digital ${ }^{49}$.

A tela inicial do sistema, bem como suas funcionalidades, manteve o layout criado pelo CAED, conforme apresentado a seguir:

\footnotetext{
${ }^{47}$ Antes era https://simade.caedufjf.net/SimadeWeb/login.faces e passou a ser http://www.simadeweb.educacao.mg.gov.br/SimadeWeb/inicio.faces

48 Até 2015, tais responsabilidades eram do Centro de Políticas Públicas e Avaliação da Educação da Universidade Federal de Juiz de Fora (CAEd/UFJF).

49 Sistema criado pela SEE/MG com intuito de possibilitar a inserção diária da frequência, lançamento de notas, conteúdos, etc. Seus usuários são os professores e supervisores escolares, além de diretores vice-diretores, ATBs e secretários escolares da rede pública estadual de Minas Gerais.
} 


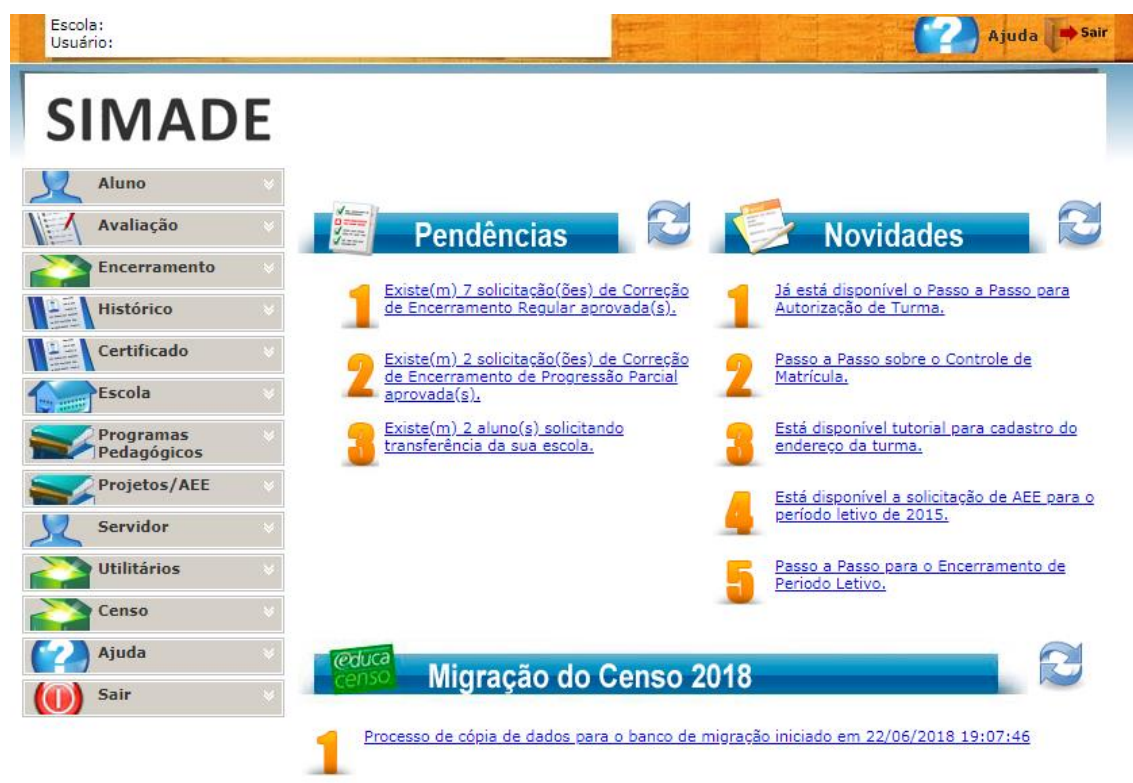

Fonte: http://www.simadeweb.educacao.mg.gov.br/SimadeWeb/inicio.faces

Em 2018 o sistema apresentava 13 menus, distribuídos em 80 submenus, independente do perfil do usuário, e a estrutura do sistema pode ser desmembrada em cinco dimensões:

(i) Configuração - são estabelecidos os parâmetros iniciais para a utilização do sistema, como, por exemplo, a criação do(s) período(s) letivo(s) ${ }^{50}$, das disciplinas (percentual para aprovação, se aceita progressão parcial, etc.), turno, horário, turma, espaços (salas de aula), etc.;

(ii) Cadastro da escola, dos alunos e dos docentes - preenchimento dos dados essenciais para escola, alunos e docentes, permitindo: inserção, alteração, consulta, exclusão e impressão de dados sobre a unidade de ensino (infraestrutura, equipamentos, dados sobre as etapas atendidas, total de funcionários e alimentação escolar); bem como identificação dos alunos e dos responsáveis (endereço, documentação) e dados de saúde do discente; dados pessoais e funcionais do docente, escolaridade e disciplina;

(iii) Acompanhamento do aluno - dados relativos à vida escolar do aluno (matrícula, enturmação, histórico, transferência, evasão,

\footnotetext{
${ }^{50}$ A escola pode criar um período letivo anual e/ou períodos letivos semestrais.
} 
abandono discente e aspectos pedagógicos - dados relacionados ao programa pedagógico, notas, frequência, parecer descritivo, rendimento bimestral/trimestral e resultados finais de alunos regulares e com progressão parcial;

(iv) Aspecto administrativo - equipamentos, legislação e documentos de criação da escola, dos discentes e docentes e contratação de profissionais da educação;

(v) Configuração das legislações nacionais e estaduais que regem o sistema de ensino mineiro - cadastro das leis para emissão do histórico escolar. Esses dados são de preenchimento obrigatório no sistema.

Assim como outros sistemas de gestão escolar já investigados em pesquisas internacionais (CUNHA, 2013; SHAH, 2014), o SIMADE pode ser utilizado de forma a enfatizar os processos administrativos, dando suporte à gestão dos principais recursos, tais como: assiduidade, horários, documentação dos discentes e docentes, distribuição das salas de aula, controle do número de alunos para contratação de professores e auxiliares de serviços gerais, entre outros (BALDUTI, 2017; MARTINS, 2014), ou seja, melhorar a realização das tarefas administrativas e burocráticas da escola.

Em contrapartida, quando o enfoque do uso é pedagógico, como também já observado em outros sistemas de gestão, em pesquisas internacionais (DEMIR, 2006), o SIMADE pode organizar os dados educacionais com o intuito de facilitar o monitoramento do desempenho, do rendimento, da aprendizagem e da frequência e evasão discente, bem como auxiliar na proposição de estratégias para melhorar a qualidade da educação e a tomada de decisões (SALGADO, 2014).

Em outras palavras, o SIMADE pode proporcionar maior agilidade nas intervenções pedagógicas a serem desenvolvidas e melhora o gerenciamento das informações estratégicas. Cabe ressaltar que as funcionalidades por si só não remetem a um determinado tipo de uso, pois são os usuários da escola que o definem e que atribuem sentido pedagógico ou administrativo à ação executada no sistema.

No contexto educacional, os dados, ao serem inseridos em um software de gestão escolar, configuram um sistema de informações, ou seja, um conjunto de componentes inter-relacionados que coleta (ou recupera), processa, armazena e 
distribui informações destinadas a apoiar a coordenação e o controle de uma organização, cabendo à escola a integração e processamento desses dados (CORREIA \& ZIVIANI, 2015, p. 104).

Todavia, em geral, as pesquisas não definem o que são os dados dos sistemas de gestão escolar. Entretanto, de maneira indireta, apresentam indícios de um entendimento que remete à perspectiva da Ciência da Informação ${ }^{51}$ e da Tecnologia da Informação ${ }^{52}$ gerando conceitos distintos que enfatizam elementos e processos distintos em relação ao dado. Na primeira, o dado é considerado um dos componentes de uma tríade, sendo compreendido como aquilo que tem existência material, como por exemplo, os documentos, os registros de conhecimento, etc.; o conhecimento se refere ao que está dentro da mente dos indivíduos; e, entre ambos, como resultado da interação, está a informação. Nessa perspectiva, a informação alterada pela incorporação de um novo dado gera conhecimento (TEIXEIRA \& VALENTIM, 2017; ARAÚJO, 2014). Dessa forma, um dado de um sistema de gestão escolar pode gerar uma nova informação para a escola (FONSECA, 2014).

$\mathrm{Na}$ Tecnologia da Informação, o dado é compreendido como um elemento da informação (um conjunto de letras ou dígitos) que, tomado isoladamente, não transmite nenhum conhecimento, ou seja, não contém um significado intrínseco (BIO, 1988). Já a informação "é um dado que foi processado de uma forma significativa pelo receptor e seu valor é real ou percebido no momento, ou em ações prospectivas nas decisões" (DAVIS \& OLSON, 1987, p. 208). Esses dados são apresentados nos mais diversos suportes e formatos, representados na forma de texto, áudio, vídeo, imagem, etc., manipulados em grandes quantidades, que permitem a aplicação de diferentes técnicas de análise, as quais facilitam a aquisição e transferência de conhecimento, além de gerar informações úteis, precisas e confiáveis (SANTOS \& FLORES, 2018; NORAMBUENA \& ZEPEDA, 2017). Nessa perspectiva, o sistema de gestão escolar é preenchido com dados que

51 "Investiga as propriedades e o comportamento informacional, as forças que governam os fluxos de informação, e os significados do processamento da informação, visando à acessibilidade e a usabilidade ótima. A Ciência da Informação está preocupada com o corpo de conhecimentos relacionados à origem, coleção, organização, armazenamento, recuperação, interpretação, transmissão, transformação, e utilização da informação" (BORKO, 1968, p. 1).

52 Trata-se de um conjunto de atividades, soluções, equipamentos e pessoas envolvidas na produção, armazenamento, segurança, gerenciamento, transmissão e acesso de informação. Através de hardwares e softwares é realizada a automação de processos com menor tempo e esforço físico. Envolve a Ciência da Computação, a Engenharia de Software, os Sistemas de Informação, etc. 
são transformados em informações, as quais respondem a diferentes questões dentro da escola (BALDUTTI, 2017).

Em âmbito educacional, segundo Luiz Antônio Cunha (1975), os dados são números que falam por meio de um sistema prévio que lhes dá sentido, permitindo que se faça um diagnóstico da realidade educacional. Para o autor, o diagnóstico faz os dados falarem, trazendo ao conhecimento dos planificadores a existência (e o dimensionamento) de problemas às vezes insuspeitos (CUNHA, 1975, p. 116). No entanto, atualmente, na área educacional, não há uma distinção nítida entre dado $^{53}$ e informação ${ }^{54}$, pois o próprio INEP, agrupando dados ${ }^{55}$ oriundos das avaliações em larga escala, como o SAEB e a Prova Brasil, e/ou de Censos, como por exemplo, o Censo Escolar, define dados como informações estatísticas disponíveis. Parra e Matus (2016) afirmam que o termo dado tem sido utilizado de forma reduzida fazendo referência apenas à informação do tipo somativa que envolve os resultados de aprendizagem dos estudantes nas avaliações externas, vez que sua compreensão está vinculada a lógica de prestação de contas das políticas públicas em relação as escolas.

No SIMADE, o dado é compreendido de uma forma mais próxima à da Tecnologia da Informação, apresentando informações significativas dos estudantes, das famílias, dos docentes e das escolas, permitindo representar diversos aspectos da instituição de ensino. Entretanto, ele agrupa dados de diferentes fontes, como os presentes nos grandes objetivos educacionais consagrados na Constituição Federal de 1988, na LDB 9394/96, dentre outros dispositivos legais, particularmente os da rede estadual de Minas Gerais, além de dados da própria escola, como o projeto político pedagógico, dados dos funcionários, resultados e até informação oral. Esses dispositivos trazem toda a orientação legal que define o funcionamento do sistema - carga horária por anos de ensino; base nacional comum e parte diversificada; percentuais para aprovação e de frequência, etc.

Primordialmente, os dados do SIMADE são os que compõem a base do Censo Escolar, com informações sobre o ensino regular, educação especial,

\footnotetext{
${ }^{53}$ Um valor, um nome, um endereço, uma classificação acadêmica são exemplos de dados.

${ }^{54}$ Os dados, após serem tratados, se transformam em informações, ou seja, a informação é o resultado do processamento do dado.

${ }^{55}$ Exame Nacional do Ensino Médio (ENEM); Exame Nacional para Certificação de Competências de Jovens e Adultos (ENCCEJA); avaliações de âmbito estadual, como, por exemplo, o SIMAVE; Pesquisa Nacional por Amostra de Domicílios (PNAD) e o Censo Populacional, que coletam, respectivamente, indicadores de acesso e rendimento e informações sobre taxa de escolarização.
} 
educação e jovens e adultos (EJA) e educação profissional das escolas de Minas Gerais, além de dados sobre: as unidades de ensino, matrículas, turmas, profissionais da educação, movimento e rendimento escolar dos alunos. Roque e Costa (2007), em artigo que destaca a importância do estudo das questões relativas à gestão da informação nas organizações escolares, apontam que há um fluxo grande de informações que circulam no contexto escolar - organizacional $^{56}$, pedagógica $^{57}$, legal ${ }^{58}$, administrativa ${ }^{59}$, científica ${ }^{60}$, diversa $^{61}$. No que concerne ao SIMADE, os dados são majoritariamente da vida escolar dos alunos englobando, portanto, dados organizacionais, pedagógicos, legais e administrativos.

Porém, apesar de haver um fluxo de dados que propicia a transformação dos dados em informações e a proposta de uso do SIMADE se dar com intuito de melhorar o funcionamento da escola (melhorar o processo de tomada de decisão e atingir os objetivos propostos) (CAEd, 2014, s/p), são os profissionais das instituições de ensino que atribuem sentido e propósito aos dados. Diretores, secretários e/ou ATBs, portanto, assumem papeis decisivos, pois são eles que recebem os dados, os organizam e os processam, transformando-os em informação, manipulando-os, consolidando-os, isto é, dando-lhes um propósito, infundindo-lhes um significado. Ou seja, são eles, em última instância, que definem quais dados serão extraídos do sistema e, posteriormente, como serão utilizados (MASSA et al., 2018; VENTURA \& NASSIF, 2016). A interpretação de cada indivíduo sobre o valor e significado do dado, bem como sobre ele integrar o seu cotidiano, pode ser a base para o exercício da discricionariedade no uso dos dados do sistema.

Soma-se a isso o fato de existirem funcionalidades específicas para a extração dos dados do sistema ${ }^{62}$, que podem ser consultadas, salvas ou impressas através do menu Utilitários, que disponibilizam relatórios sobre alunos, turmas, docentes, notas, diários, declarações, listagens, etc., conforme ilustrado na imagem a seguir:

\footnotetext{
${ }^{56}$ Exemplos: distribuição de serviço, calendário de atividades, etc.

${ }^{57}$ Exemplos: métodos de ensino/aprendizagem, currículos, etc.

${ }^{58}$ Exemplos: leis, decretos, portarias, etc.

${ }^{59}$ Exemplos: dados pessoais, resultados escolares, assiduidade, etc.

${ }^{60}$ Exemplos: livros, revistas, etc.

${ }^{61}$ Exemplos: atividades desportivas e culturais, festas, etc.

62 Os dados do Diário Digital migram para o SIMADE, mas as informações do SIMADE não são migradas para o Diário Digital. Portanto, o sistema que contém todas as informações sobre a escola e, consequentemente, sobre a rede de ensino, é o SIMADE.
} 
Figura 2: Relatórios do SIMADE
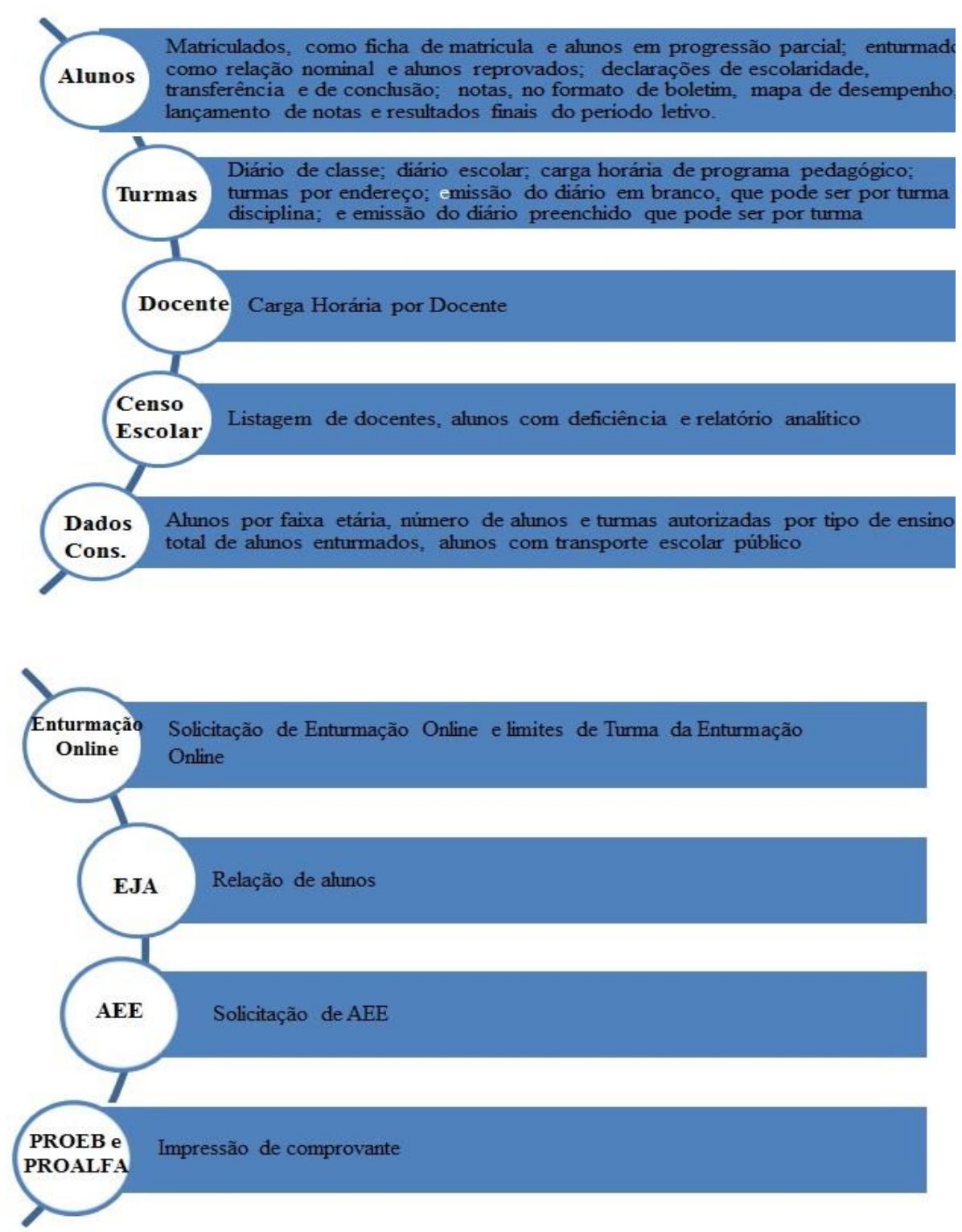

Fonte: SIMADE63

O SIMADE é constituído por uma diversidade de dados e recursos que podem ser utilizados para a obtenção e disseminação de informações, além de possibilitar o processamento de qualquer informação administrativa ou pedagógica da escola, promovendo maior proximidade entre SRE, SEE/MG e a escola.

${ }^{63} \mathrm{O}$ diário de classe e o diário escolar, respectivamente, podem ser visualizados e impressos por turma ou disciplina; ou somente por turma. Transporte público, presente em Dados Consolidados, é realizado por vans e ônibus escolares, ou por meio de vale-transporte concedido aos alunos para deslocamento até a escola em ônibus circulares. Em Enturmação Online constam as informações da solicitação de abertura de novas turmas nas escolas, ao passo que, no Limites de Turma da Enturmação Online encontram-se as turmas, juntamente com o quantitativo de alunos matriculados e enturmados, criadas a partir da autorização da SRE. Em PROEB e PROALFA, é possível imprimir o comprovante de participação nas duas avaliações em larga escala. O passo a passo, atualmente disponível junto às opções do menu Relatório, tem a função de explicar detalhadamente cada botão do referido menu. Esse relatório consta do anexo deste trabalho. 
Portanto, a escola e seus atores, apresentam a potencialidade de transformação, de construção de identidade e de modos próprios de funcionamento, os quais, em certa medida, podem se refletir no uso dos dados do SIMADE.

Diante desse panorama, proponho, neste estudo, investigar quais têm sido os usos dos dados do Sistema Mineiro de Administração Escolar (SIMADE) como ferramenta de gestão para os diretores da rede estadual de Minas Gerais. No próximo capítulo será apresentado o percurso da pesquisa desenvolvida para responder a este objetivo geral. 


\section{DELINEAMENTO DA PESQUISA: o problema, as hipóteses, as questões, os objetivos e o caminho metodológico}

O diretor desempenha um papel central na gestão da escola, organizando, mobilizando e articulando todas as condições materiais e humanas para garantir os processos educativos, como principal responsável por fazer a escola funcionar. O trabalho do diretor encontra lastro no trabalho de outras pessoas, como o secretário escolar e o ATB, e também no uso de instrumentos que podem auxiliar na gestão da escola, como o SIMADE. Considerando que o SIMADE armazena, organiza e fornece dados, principalmente sobre a trajetória acadêmica dos alunos, e que tais dados podem subsidiar ações e decisões baseadas em evidências, seu uso pode adquirir contornos administrativos ou pedagógicos, de acordo com as características do diretor e da gestão da escola. No contexto da rede estadual de ensino de Minas Gerais, cabe, então, indagar: como as unidades escolares utilizam os dados fornecidos pelo SIMADE? Em que medida a infraestrutura escolar influencia no uso dos dados do SIMADE nas escolas? Qual é a percepção de diretores e secretários em relação ao sistema? A autoeficácia do diretor pode influenciar o uso dos dados do SIMADE?

A originalidade do SIMADE reside em ter perfis (SEE/MG, SRE e escola), que permite um acompanhamento em tempo real de dados do sistema educacional ou da unidade de ensino, possibilitando também monitorar o desempenho, frequência e rendimento dos alunos matriculados em diferentes níveis e etapas da educação básica, além de ser utilizado por 3.644 escolas da rede estadual de Minas Gerais.

A partir desse cenário de pesquisa, da revisão bibliográfica apresentada, da experiência (por quase sete anos) de trabalho com o SIMADE, do diálogo com analistas do CAEd, com gestores de escolas estaduais e analistas de educação das SREs, além das incursões exploratórias nas pesquisas realizadas, definimos como objeto desta pesquisa a identificação dos usos e as percepções da utilidade dos dados do SIMADE nas escolas estaduais de Minas Gerais, e elencamos algumas hipóteses de investigação: 
- As formas de uso do SIMADE no nível da escola estão relacionadas à autoeficácia do gestor escolar.

- A usabilidade do SIMADE influencia no uso dos dados pela escola.

A partir dessas hipóteses, apresenta-se como questão central de pesquisa:

Quais têm sido os usos dos dados do Sistema Mineiro de Administração Escolar (SIMADE) como ferramenta de gestão para os gestores das escolas públicas da rede estadual de Minas Gerais?

Dessa questão central, emergem como objetivos específicos:

- Caracterizar como os gestores escolares utilizam os dados do SIMADE como um instrumento de gestão escolar;

- Analisar a influência da usabilidade do SIMADE no uso efetivo do sistema;

- Analisar as possíveis relações entre as crenças de autoeficácia de diretores escolares e o uso do SIMADE nas escolas.

No próximo tópico, será apresentada a descrição do caminho metodológico desta pesquisa.

\subsection{0 caminho metodológico}

Para a definição da metodologia, assim como observado por Santos (2009), o primeiro questionamento se relaciona ao recorte da pesquisa. Optamos por englobar todas as escolas, ou seja, as 3644 escolas de Minas Gerais, com a utilização somente dos questionários aplicados em larga escala, adotando apenas a abordagem quantitativa. A abordagem quantitativa, de acordo com Filho e Gamboa (2009, p. 42), busca explanar "as causas das mudanças nos fatos sociais, principalmente por meio de medida objetiva e análise quantitativa. Seu objetivo básico é a predição, a testagem de hipóteses e a generalização".

Para a coleta inicial de dados, foi utilizado o questionário, que pode ser definido "como a técnica de investigação composta por um número mais ou menos elevado de questões apresentadas por escrito às pessoas, tendo por objetivo o conhecimento de opiniões, crenças, sentimentos, interesses, expectativas, situações 
vivenciadas etc.” (GIL, 1999, p. 128). Para Minayo (2005), os questionários configuram-se como "dispositivos normatizados e padronizados, que captam a presença ou ausência de determinada característica ou atributo do indivíduo, permitindo medir a magnitude com que essa característica ou atributo se distribui naquele grupo" (MINAYO, 2005, p. 133).

A primeira versão dos questionários, aplicados em todas as escolas estaduais de Minas Gerais, foram validadas em uma pesquisa exploratória com quatro escolas de anos iniciais de Juiz de Fora (MG), em 2015. Esses instrumentos foram posteriormente aperfeiçoados através de um pré-teste junto a uma amostra de respondentes com características semelhantes à população-alvo de maneira a viabilizar a correção de eventuais erros de formulação (MARCONI \& LAKATOS, 1999). O pré-teste foi aplicado em escolas da rede municipal de educação de Juiz de Fora (MG) em 2017. Essa rede foi escolhida porque desde 2004 utiliza o sistema de gestão SisLAME, muito semelhante ao SIMADE, tanto em termos de funcionalidades - cadastro, matrícula, lançamento de notas de alunos, etc. - quanto por possibilitar um monitoramento dos dados educacionais pelas escolas e também por ter uma boa diversidade de etapas atendidas ${ }^{64}$.

Para as escolas municipais de Juiz de Fora, foram enviados por e-mail os links dos questionários do diretor, com 27 questões, e de um representante da secretaria da escola, com 30 perguntas. Foi necessária a realização de contato telefônico para informar sobre a pesquisa e foram feitas várias visitas às escolas para obter uma quantidade razoável de questionários preenchidos. Após o pré-teste, foram realizados ajustes nos instrumentos para que, posteriormente, eles fossem aplicados a todas as escolas estaduais de Minas Gerais ${ }^{65}$.

Com o intuito de obter a autorização para a realização da pesquisa, agendamos $^{66}$ uma reunião com a equipe da $\mathrm{SEE} / \mathrm{MG}^{67}$, realizada na sede da secretaria de educação, em julho de 2017, na cidade de Belo Horizonte. Na ocasião apresentamos a pesquisa, com maior ênfase na parte metodológica, que necessitava

\footnotetext{
${ }^{64}$ A rede municipal de ensino de Juiz de Fora é composta por 102 escolas e contabilizou 44.267 matrículas em 2017, atendendo à Creche e a Educação Infantil (22,37\%), ao Ensino Fundamental $(55,27 \%)$, à Educação de Jovens e Adultos (EJA) nas duas etapas do Ensino Fundamental $(18,15 \%)$ e Educação Especial (3,98\%) (CENSO, 2017).

${ }^{65}$ Isso será descrito no item 2.3 deste capítulo.

${ }^{66} \mathrm{~A}$ autora e orientadora desta pesquisa

${ }^{67}$ Participantes da SEE/MG: Diretora de Acompanhamento de Projetos e Resultados Educacionais (DAPE); Subsecretária de Informações e Tecnologias Educacionais; e o Superintendente de Informações Educacionais.
} 
de apoio da SEE/MG para a aplicação dos questionários de diretor e secretários em todas as escolas da rede pública estadual de Minas Gerais. O primeiro apoio da SEE/MG foi a autorização para realização da pesquisa nas escolas, concedida em outubro de 2017 68 ; o segundo foi o envio de um e-mail para todas as SREs e para as escolas, autorizando a pesquisa e apresentando como seria a sua realização (questionários enviados por e-mail para diretores e secretários); e o terceiro foi a disponibilização da listagem com os e-mails institucionais de todas as escolas estaduais.

De posse da autorização e as escolas já cientes da pesquisa, iniciamos os procedimentos, semelhantes aos adotados no pré-teste, para a aplicação dos questionários nas 3.644 escolas estaduais de Minas Gerais, no período de outubro de 2017 a janeiro de 2018. No entanto, devido à extensão geográfica do estado e à dificuldade de contato com as escolas no período de encerramento do ano letivo e férias dos servidores no mês de janeiro, a única forma de divulgação dos questionários foi o envio dos links para os e-mails institucionais. Foram criados layouts - textos, cores e imagens - e links diferentes para os e-mails dos diretores e secretários, apresentados no anexo 2 .

Obtivemos as respostas de 586 escolas em que diretores e secretários/ATB responderam aos questionários, tendo sido o convite para participar da pesquisa enviado pela SEE/MG a todas as SREs, na forma de um comunicado; e aos integrantes da equipe administrativa da escola - diretores e secretários -, como uma convocação. Acreditamos que, por serem mais sensíveis às convocações dos burocratas do nível central ${ }^{69}$, um maior número de escolas respondeu ao questionário. No entanto, tais profissionais podem ter interpretado a necessidade de responder informando o que a SEE/MG gostaria de "ouvir". Mesmo assim, o conjunto dos dados tem uma razoável variabilidade, com respostas consistentes em certa medida com o que fora mencionado nas incursões exploratórias.

Buscando analisar se os resultados fornecidos nos instrumentos eram compatíveis com a realidade da escola, foram realizadas cinco entrevistas semiestruturadas - que combinam perguntas abertas e fechadas idênticas ao

\footnotetext{
${ }^{68}$ Anexo 1

${ }^{69}$ Nesta pesquisa, o nível central se subdivide em burocratas de alto escalão - decisores com responsabilidade políticas - como a SEE/MG e burocratas de médio escalão - funcionários situados no meio da estrutura hierárquica das organizações e que são encarregados de operacionalizar as estratégias que o alto escalão da burocracia formula (LOTTA, 2014), como a SRE.
} 
questionário do diretor - com gestores de escolas da rede estadual de Minas Gerais que haviam respondido ao instrumento. $\mathrm{O}$ intuito era validar se as respostas dos questionários eram compatíveis com o que estava sendo respondido nas entrevistas.

Para tal, cinco diretores foram escolhidos devido à facilidade de acesso, já que em outubro de $2018^{70}$ eles estavam participando, presencialmente, do mestrado em Gestão e Avaliação da Educação Pública, na cidade de Juiz de Fora, que fica próxima à residência da pesquisadora. Esse grupo era composto por profissionais que atuavam em escolas de diferentes SREs, regiões de Minas Gerais e em escolas que a localização, docentes e IDEB eram bem distintos. Os resultados das entrevistas se mostraram muito semelhantes ao que havia sido respondido no questionário, indicando que o referido instrumento apresenta respostas que ilustram a realidade da escola.

Com os dados coletados das 586 escolas criamos uma base, à qual posteriormente agregamos dados do Censo Escolar de 2016, Sistema Mineiro de Avaliação e Equidade da Educação (SIMAVE) de 2016 e Prova Brasil de $2015^{71}$. Os dados do Censo Escolar nos permitiram a caracterização das escolas em que tanto o diretor como os secretários haviam respondido aos questionários, apontando a distribuição de matrículas, a localização, turnos de funcionamento, as etapas atendidas e o indicador de complexidade da gestão ${ }^{72}$. Os dados do SIMAVE e da Prova Brasil agregaram informações sobre a proficiência média dos alunos de cada escola.

O SIMAVE é uma avaliação em larga escala que, desde 2000, é aplicada anualmente com o intuito de aferir o desempenho dos alunos da rede pública estadual de Minas Gerais, visando fomentar mudanças em prol de uma educação de

\footnotetext{
70 As entrevistas ocorreram no período de 14 a 19 de outubro, semana de recesso das escolas estaduais de Minas Gerais.

${ }^{71}$ Vale destacar que esses dados eram os mais recentes disponíveis, respectivamente, no CAEd e no site do INEP).

72 Esse indicador foi criado e disponibilizado pelo MEC em 2015 para mensurar, a partir dos dados do Censo Escolar, a complexidade da gestão das escolas de educação básica brasileiras. O indicador é composto por quatro características: (i) porte da escola; (ii) número de turnos de funcionamento; (iii) complexidade das etapas ofertadas pela escola e (iv) número de etapas/modalidades oferecidas. As variáveis criadas para representar essas características são do tipo ordinal, nas quais as categorias mais elevadas indicariam maior complexidade de gestão. O cálculo do indicador "baseado na Teoria de Resposta ao Item (TRI), - considerando a existência de um único traço latente" (BRASIL, 2015, p. 2). Para mais informações pode-se consultar a Nota Técnica Indicador de Complexidade da Gestão no Portal do Instituto Nacional de Estudos e Pesquisas Educacionais Anísio Teixeira (INEP).
} 
qualidade. O SIMAVE é composto por duas avaliações ${ }^{73}$ : (i) Programa de Avaliação da Rede Pública de Educação Básica (PROEB) - avaliação censitária dos alunos do $5^{\circ}$ e $9^{\circ}$ ano do Ensino Fundamental e $3^{\circ}$ ano do Ensino Médio em Língua Portuguesa e Matemática; (ii) Programa de Avaliação da Alfabetização (PROALFA) - avaliação que possibilita a medição censitária dos níveis de alfabetização dos alunos do $3^{\circ}$ ano da rede pública de ensino de Minas Gerais em Língua Portuguesa e Matemática (FRANCO \& CALDERON, 2017).

Já a Prova Brasil é censitária e aplicada bianualmente em escolas da zona rural e urbana a alunos do $5^{\circ}$ e $9^{\circ}$ ano do Ensino Fundamental. Fornece médias de desempenho para o Brasil, regiões, unidades da federação, municípios e escolas participantes nas disciplinas de Língua Portuguesa e Matemática. Os dados de proficiência dessas duas avaliações (nos anos de 2015, Prova Brasil, e 2016, SIMAVE), permitiram realizar o cálculo do indicador de desempenho bruto das escolas a partir da média de proficiência na disciplina de Matemática.

A seguir, serão apresentados os resultados do pré-teste - procedimentos de aplicação e as necessidades de ajuste dos instrumentos -, o referencial teórico que fundamentou a criação dos novos questionários e a estrutura dos novos instrumentos.

\subsection{O pré-teste na rede pública municipal de Juiz de Fora: validação dos instrumentos}

Entre os dias 20 de março e 15 de maio de 2017, os links dos questionários elaborados na ferramenta SurveyMonkey ${ }^{74}$ foram enviados ao e-mail institucional das 98 escolas da rede municipal de Juiz de Fora com o intuito de, seguindo as considerações de alguns autores (MARCONI \& LAKATOS, 2003; GIL, 2002; BARROSO, 2012), testar os procedimentos de aplicação do questionário e assegurar-se de que as questões ou observações a serem realizadas possibilitariam analisar as variáveis que se pretende medir. Além disso, os instrumentos foram

\footnotetext{
73 Também é composto pelo Programa de Avaliação da Aprendizagem Escolar (PAAE) que visa identificar as necessidades imediatas de intervenção pedagógica por meio de geração de provas prédefinidas, que permitem identificar as necessidades imediatas de intervenção pedagógica.

${ }^{74}$ Ferramenta de criação e aplicação de questionário online.
} 
validados por quatro pareceristas ${ }^{75}$ que indicaram melhorias no enunciado das questões para torna-las mais compreensíveis para os respondentes.

Para a delimitação da amostra de respondentes foram considerados os seguintes critérios: ser usuários cadastrado no SisLAME, o que resultou na exclusão de duas escolas - um centro de formação do professor e uma escola inativa; diretores e secretários atuantes em mais de uma escola foram orientados a responder o questionário somente referente a uma delas ${ }^{76}$, e, em virtude disso, duas escolas foram eliminadas. Portanto, do total de 102 escolas pertencentes à rede pública municipal de Juiz de Fora, a amostra do pré-teste foi composta por 98 unidades escolares.

Ao final do pré-teste, foram contabilizadas 49 respostas de diretores e 51 de secretários, porém, em apenas 34 unidades de ensino os dois profissionais responderam, totalizando: quatro que atendem apenas a Educação Infantil; dez de Educação Infantil e Anos Iniciais do Ensino Fundamental; uma somente de Anos Iniciais do Ensino Fundamental; quatro de Ensino Fundamental; uma de Ensino Fundamental e Educação de Jovens e Adultos (EJA); três de Educação Infantil, Ensino Fundamental e EJA; uma somente EJA; e nove de Educação Infantil e Ensino Fundamental.

Em relação à aplicação dos questionários do pré-teste, foi possível constatar alguns procedimentos que necessitavam de ajustes, conforme descritos no quadro a seguir:

\footnotetext{
${ }^{75}$ Três pareceristas são professores do departamento de educação da PUC-Rio e uma é docente do departamento de educação da UNIRIO.

${ }^{76} \mathrm{O}$ diretor pode escolher sobre qual escola ele responderia.
} 
Quadro 1: Procedimentos realizados e ajustes necessário para a aplicação do questionário

\begin{tabular}{|l|l|}
\hline \multicolumn{1}{|c|}{ Procedimentos } & \multicolumn{1}{|c|}{ Ajuste necessário } \\
\hline $\begin{array}{l}\text { E-mail institucional das escolas bloqueava o e- } \\
\text { mail com os links dos questionários do pré- } \\
\text { teste. }\end{array}$ & $\begin{array}{l}\text { Criar um e-mail que fosse aceito pelos e-mails } \\
\text { institucionais das escolas estaduais de MG. }\end{array}$ \\
\hline $\begin{array}{l}\text { Questões iniciais idênticas nos dois } \\
\text { questionários do pré-teste, o que causou } \\
\text { dúvidas se era um único instrumento para } \\
\text { diretores e secretários. }\end{array}$ & $\begin{array}{l}\text { Cada instrumento a ser aplicado nas escolas } \\
\text { estaduais de MG precisa ter um texto de } \\
\text { apresentação claro sobre quem deve respondê- } \\
\text { los e questões iniciais distintas. Além de layout } \\
\text { textos, cores e imagens - diferentes. }\end{array}$ \\
\hline $\begin{array}{l}\text { Assunto dos e-mails enviados para os diretores } \\
\text { e secretários era SisLAME, fazendo com o que } \\
\text { o secretário achasse que o questionário era só } \\
\text { para ele, ou seja, para quem preenche o } \\
\text { sistema. }\end{array}$ & $\begin{array}{l}\text { Acrescentar no assunto do e-mail enviado para } \\
\text { as escolas estaduais de MG a palavra diretor ou } \\
\text { secretário. }\end{array}$ \\
\hline $\begin{array}{l}\text { Respostas duplicadas devido à dúvida sobre a } \\
\text { finalização do questionário. }\end{array}$ & $\begin{array}{l}\text { Inclusão de uma mensagem que confirmasse a } \\
\text { finalização dos questionários e agradecesse a } \\
\text { participação do respondente. }\end{array}$ \\
\hline $\begin{array}{l}\text { Frequentes quedas de conexão com a internet } \\
\text { interrompiam o preenchimento dos } \\
\text { instrumentos e os usuários não conseguiam } \\
\text { responder novamente, usando o mesmo código } \\
\text { da escola e o mesmo computador. }\end{array}$ & $\begin{array}{l}\text { Configurar os questionários das escolas } \\
\text { estaduais de MG para permitir mais de uma } \\
\text { resposta por escola (diretor e secretário) e do } \\
\text { mesmo computador. }\end{array}$ \\
\hline
\end{tabular}

Fonte: Questionários do pré-teste (diretor e secretário).

No que concerne às questões, durante a aplicação do pré-teste, foi possível constatar a necessidade de eliminar, modificar e incluir perguntas e alternativas de respostas, bem como alterar o formato de algumas questões. Podemos elencar oito ajustes realizados nos instrumentos: (i) exclusão de questões que poderiam ser retiradas de outras fontes de informação (exemplo etapas atendidas pela escola); (ii) exclusão de alternativas de respostas que os respondentes tiveram dificuldade de compreender (exemplo conexão banda larga); (iii) alteração de enunciados, buscando deixar mais claro o objetivo da questão; (iv) inserção de alternativas de respostas, pois verificamos que, no momento presencial, alguns respondentes escreveram algo ao invés de assinalar uma das opções de resposta; (v) não obrigatoriedade de respostas para algumas perguntas, vez que todas estavam como obrigatórias; (vi) alteração do tipo de pergunta, como exemplo pergunta fechada que passou a ser do tipo matriz ${ }^{77}$; (vii) desmembramento de questões em outras perguntas para tornar a respostas dos respondentes mais claras; (viii) junção de questões semelhantes. O quadro que ilustra as transformações que foram realizadas se encontra no anexo 3 desta tese.

\footnotetext{
77 Pergunta fechada que solicita que os respondentes avaliem um ou mais itens de linha utilizando
} o mesmo conjunto de opções de coluna. 
O pré-teste permitiu que fosse verificada a validade dos dados coletados para a pesquisa, o vocabulário, problemas e dúvidas nas questões, o procedimento de aplicação e a medição das variáveis. Ademais, também emergiram algumas lacunas, as quais indicaram a necessidade de se formular novas questões a serem inseridas nos instrumentos, buscando contemplar mais informações sobre as ações que os diretores exercem em seu cotidiano e que podem estar relacionadas ao uso do SIMADE e de seus dados.

\subsection{A elaboração dos questionários das escolas estaduais de Minas Gerais: aprofundando o referencial teórico}

Para a complementação da fundamentação teórica, buscamos artigos no período de agosto de 2018 a janeiro de 2019, principalmente nas bases de dados do Scientific Electronic Library Online (SciELO), no portal de Periódicos Eletrônicos de Psicologia (PePSIC) e no Sistema de Información Científica Redalyc Red de Revistas Científicas de América Latina y el Caribe, España y Portugal. Para tal usamos as seguintes palavras-chaves e expressões: gestão escolar, atividades/tarefas/atribuições do diretor, sistema de gestão escolar, SIMADE, administrativo pedagógico, autoeficácia do diretor. Foram também lidas referências citadas em obras consultadas a partir das bases de dados mencionadas. O intuito era selecionar artigos que tivessem as palavras-chave gestão escolar, atividades/tarefas/atribuições do diretor, sistema de gestão escolar, SIMADE, administrativo pedagógico, autoeficácia do diretor.

Encontramos 42 artigos publicados entre 2012 e 2018 que abordaram, de alguma forma, o cotidiano dos gestores escolares, embora a temática das pesquisas fosse diversa. Os artigos foram categorizados a partir de seu tema central em quatro grupos: (i) contexto histórico da gestão escolar; (ii) tarefas desenvolvidas pelos gestores escolares; (iii) estilos de gestão adotados pelos diretores das escolas; (iv) autoeficácia do diretor. Os estudos apontam, em linhas gerais, que a gestão da escola é influenciada por diversas características da instituição de ensino bem como pelas tarefas administrativas e pedagógicas que os diretores mais se dedicam em seu cotidiano. Entretanto, o foco nas tarefas pedagógicas e a percepção positiva da autoeficácia do diretor refletem tanto no trabalho do professor quanto nos resultados dos alunos. 
Além de fomentar a criação de novas questões nos questionários, principalmente sobre as tarefas desenvolvidas no cotidiano dos diretores e secretários escolares, tais artigos também contribuíram para a reflexão sobre como o trabalho do diretor pode ser um elemento diferenciador na escola, vez que alguns destacam o papel central exercido pelos diretores no contexto educacional, principalmente a partir dos anos de 1990.

Nesse contexto, Lück (2013) afirma que na primeira metade do século XX, predominava nas escolas brasileiras um modelo de administração clássico, centralizador e hierarquizado, fundamentado no autoritarismo, que envolvia, de forma racional e mecanicista, a equipe escolar e os recursos educacionais (LÜCK, 2013). O trabalho do diretor, segundo Lück (2000), consistia em "repassar informações, controlar, supervisionar, "dirigir" o fazer escolar de acordo com as normas propostas pelo sistema de ensino ou pela mantenedora" (LÜCK, 2000, p.13). Suas ações eram fragmentadas e quase inteiramente "ordenada[s] de fora para dentro e, do ponto de vista formal, era quase restrito ou inexistente o espaço de decisão da escola sobre seus objetivos, formas de organização e gestão, modelo pedagógico e, sobretudo, sobre suas equipes de trabalho" (MACHADO, 2000, p. 99).

Com o processo de democratização do ensino iniciado na década de 1980, materializado na Constituição Federal de 1988 e na Lei de Diretrizes e Bases da Educação Nacional n ${ }^{\circ}$ 9.394/96, e acompanhado da ampliação do acesso, especialmente das crianças de 7 a 14 anos ao Ensino Fundamental, emergiram diversas propostas de reforma educacional com o intuito de melhorar a qualidade da educação pública. $\mathrm{O}$ foco de tais reformas passa a ser o trabalho realizado dentro das escolas, oferecendo lugar de destaque para a gestão escolar na agenda da política educacional desde a década de 1990 (OLIVEIRA \& PAES DE CARVALHO 2018; LEITE \& LIMA, 2015; WERLE \& AUDINO, 2015).

Esse olhar está ancorado na observação, já constatada por inúmeros estudos, os quais observam que, dentre as características das escolas e de seus processos internos que favorecem o melhor desempenho dos alunos, está a gestão escolar, apontada por diversas pesquisas sobre escolas eficazes desde a década de 1970 (BONAMINO, 2012; SAMMONS, 2008) como um fator que pode contribuir para melhorar as práticas escolares. Para Piedade e Pedro (2014), em artigo descritivo que analisa o índice de utilização das tecnologias digitais nas práticas de gestão 
escolar, os diretores são "os responsáveis pela identificação e definição de estratégias que serão necessárias nos seus contextos educativos para que qualquer mudança de prática se instale" (PIEDADE \& PEDRO, 2014, p. 112).

Leite e Lima (2015), em um artigo que visa refletir sobre uma ação de formação continuada com diretores fundamentada na pesquisa de ação colaborativa, entendem que o papel dos diretores é "decidir sobre os problemas e dilemas da organização escolar, integrando os membros da equipe escolar num processo de análise e reflexão, em busca de soluções para os desafios com que se deparam em seu trabalho cotidiano" (LEITE \& LIMA, 2015, p. 46-47). Para tal, é necessário que o diretor escolar tenha o conhecimento de todas as dimensões que compõem o trabalho e a organização escolar, sendo capaz de articulá-las com o intuito de alcançar os objetivos e metas da escola.

O cotidiano da escola, no entanto, não apresenta consenso em relação às atribuições desempenhadas pelo diretor, embora diversos estudos indiquem que os diretores desempenham um papel-chave na transformação do cotidiano escolar, mesmo que o impacto de suas intervenções não seja necessariamente direto (ANDRADE et al., 2018). Como constatado por Polon (2012) e corroborado por Esquinsani e Silveira (2015), os processos de combinação e recombinação de prioridades em face das qualidades pessoais e profissionais, e até mesmo dos membros da equipe escolar (e da percepção que os indivíduos têm a respeito do ambiente no qual são inseridos), das especificidades e demandas da própria escola, dependência administrativa, financiamento, da capacidade de agenciamento individual e coletivo dos atores escolares e a dinâmica de interação dos profissionais da escola configuram várias formas de atuação, estabelecendo "perfis de escola" e, consequentemente, de "estilos de gestão" (POLON, 2012; PAES DE CARVALHO \& CANEDO, 2012; ESQUINSANI \& SILVEIRA, 2015).

Nesse sentido, inúmeras pesquisas qualitativas (FORMIGA \& BARBOSA, 2007; SANTANA et al., 2013; WERLE \& AUDINO, 2015) desenvolvidas, respetivamente, em escolas municipais e estadual, e estudos quantitativos (LEAL \& NOVAES, 2018), realizados na rede municipal, afirmam que o cotidiano dos diretores é primordialmente dividido entre pedagógico e administrativo. Em geral, as atribuições do diretor que concernem ao pedagógico abrangem três aspectos:

(i) assistir os membros da escola, visando à promoção de ações em conformidade com os objetivos e princípios educacionais propostos; (ii) liderar, visando à 
concretização desses objetivos e princípios; e (iii) estimular práticas inovadoras e a melhoria do processo de ensino-aprendizagem (LEAL \& NOVAES, 2018, p. 5).

Em outras palavras, o diretor tem como foco a aprendizagem dos alunos e, junto ao professor e ao coordenador pedagógico, faz o acompanhamento da aprendizagem, das ações e práticas pedagógicas dos docentes, do currículo e dos resultados discentes, isto é, de práticas que potencializam o desempenho discente (SANTANA et al., 2013; POLON, 2012).

Pesquisas de autores estrangeiros, como Urick e Bowers (2014), Leithwood (2009) e Marks e Printy (2003), e brasileiros, que utilizaram a abordagem quantitativa, como Soares e Teixeira (2006), Oliveira e Paes de Carvalho (2015) e Oliveira e Waldhelm (2016), alcançaram resultados semelhantes ao constatarem que a ênfase das atribuições do diretor no aspecto pedagógico influencia, de forma positiva, o desempenho discente. Polon (2012) e Pena e Soares (2014) ainda destacam que o perfil de liderança apresentado pelo diretor, quando enfatiza o aspecto pedagógico, também influencia positivamente o desempenho discente. De acordo com Datnow e Schildkamp (2019), os líderes desempenham um papel chave no desenvolvimento da visão, das normas e do objetivo relacionado ao uso dos dados e em propiciar uma cultura escolar que promova a tomada de decisões baseadas em evidências.

As atribuições administrativas exercidas pelo diretor no cotidiano da unidade de ensino se baseiam no "conhecimento das normas para o funcionamento da escola; planejamento, organização e controle dos recursos financeiros, dos materiais e da infraestrutura; supervisão e orientação de todas as pessoas às quais ele delega responsabilidades na escola" (LEAL \& NOVAES, 2018, p. 5). As ações administrativas são mais próximas das atividades delegadas pelos órgãos superiores de administração educacional e denotam o zelo pela parte física - infraestrutura, equipamentos, materiais de consumo ${ }^{78}$, permanente $^{79}$ e estrutural - relacionada aos documentos legitimadores do funcionamento e organização escolar, e as pessoas que atuam na escola (SOARES et al., 2017).

Em outras palavras, tais ações denotam o caráter típico de administração de recursos e procedimentos de controle e normatização do ambiente escolar que, apesar de "relacionadas ao processo de ensino-aprendizagem, não o fazem de

\footnotetext{
${ }^{78}$ Exemplos são folha ofício e caneta

${ }^{79}$ Armário e computadores são exemplos de materiais permanentes.
} 
maneira direta. Elas poderão viabilizar ou ser precondições para a realização direta do processo pedagógico que acontecem em sala de aula" (LEAL \& NOVAES, 2018, p. 5).

Em geral, as atribuições administrativas demandam a participação e apoio dos secretários escolares que, junto ao diretor, tornam-se uma equipe administrativa, que responde legalmente pela escola, além de ser um elo indissociável entre o administrativo e o pedagógico (ALMEIDA et. al., 2013). Na equipe administrativa, segundo Simão e Netto (2008), a coparticipação e responsabilização recriaram novas formas de organização do espaço escolar, que realinham as funções e relações de trabalho e conferem maior autonomia ao secretário escolar nas questões administrativas.

Soares (et al., 2017) ressalta que os diretores têm dificuldade para gerenciar as dimensões pedagógica e administrativa do trabalho escolar. Ribeiro (2012) alerta que são muitos os fatores que dificultam a atuação pedagógica, pois, ao tentar obter mudanças, nem sempre se consegue um resultado positivo, uma vez que o curto período de tempo para reuniões pedagógicas e dificuldades de relacionamento e coordenação do corpo docente podem dificultar as ações. Falta de pessoal e de condições de trabalho, além do excesso de tarefas da gestão, também são fatores que contribuem para que não sobre tempo para a dedicação às atribuições pedagógicas (SOARES et al., 2017). A natureza do trabalho do diretor escolar, segundo Oliveira (2015), considera os aspectos administrativos e pedagógicos, embora exista uma tendência a maior dedicação às questões administrativas do que as que se referem à aprendizagem dos alunos. Isso decorre da falta de preparo para promover intervenções pedagógicas, mesmo que reconheça a importância de fazêlo.

Segundo Guerreiro-Casanova e Azzi (2014), em um artigo que busca identificar a relação da autoeficácia dos gestores escolares com o índice de desempenho das escolas que eles administram, as ações da secretaria de educação também requerem dos diretores posturas técnico-burocráticas, distanciando-os das atividades pedagógicas. Já no aspecto administrativo, a infraestrutura precária, e o fato de a escola por vezes encontrar dificuldades de funcionar (material, recursos humanos, etc), podem obstaculizar as ações administrativas (DÖS \& SAVAS, 2015). 
Ainda assim, Oliveira (2015) destaca que a ação organizacional pode repercutir nos resultados dos alunos, pois "as tarefas de conciliar e manter um ambiente propício para a aprendizagem, compartilhar as metas entre a equipe e favorecer o desenvolvimento de um trabalho coletivo (onde os agentes escolares se sintam incluídos no processo)" (OLIVEIRA, 2015, p. 26) são estratégias de uma gestão eficaz. Entretanto, conhecimentos administrativos e pedagógicos são essenciais para o exercício da função de diretor, vez que a melhoria da qualidade da educação requer, [...] "além de novos conhecimentos técnicos, tempo para planejar, executar despesas, prestar contas, manter reuniões com a comunidade escolar e acompanhar o processo de ensino aprendizagem desenvolvido pela escola" (PAES de CARVALHO et al., 2014, 63).

Cabe ressaltar que, ao estabelecer metas para si e planejar cursos de ações, as pessoas mobilizam os recursos e regulam o nível de esforço necessário para realizá-lo, conduzindo a realização das ações pelo exercício do pensamento antecipatório (IAOCHITE, 2017). Para esse autor, parafraseando Bandura (1995, 1986 e 1997):

[...] a maioria das ações que realizamos é organizada incialmente no pensamento. Quando essas ações são propositivas, são reguladas pelos pensamentos antecipatórios que incorporam objetivos conhecidos e valorizados. É por via dos processos cognitivos que as pessoas podem definir objetivos, antecipar eventos, julgar suas capacidades pessoais e desenvolver estratégias que permitam a elas controlarem parcialmente aquilo que afeta suas vidas (IAOCHITE, 2017, p. 19).

Nesse sentido, um aspecto que é mediador e preditivo das ações realizadas pelos diretores escolares é sua autoeficácia para realizar e orientar ações dentro das unidades de ensino. Na direção da escola a autoeficácia pode ser definida "como um julgamento sobre as próprias capacidades para estruturar cursos de ação específicos, a fim de produzirem resultados desejados nas escolas por eles dirigidas, englobando tarefas pedagógicas, administrativas e de relacionamento interpessoal" (GUERREIRO-CASANOVA \& RUSSO, 2016).

Sendo prospectiva, ou seja, dando origem à expectativa futura (NEVES \& FARIA, 2009), essa crença atua como uma mediadora motivacional, que possibilita as pessoas ou grupos planejarem meios e estratégias, além de persistirem e se esforçarem em prover as medidas necessárias para tornar objetivos preestabelecidos em ações concretas (GUERREIRO-CASANOVA, 2014; BANDURA, 2003). 
Por ser um constructo dinâmico, que se modifica com a aquisição de novas informações e experiências pelos indivíduos, quatro fontes afetam a autoeficácia percebida pelo indivíduo (BANDURA, 1986; 1994): (i) experiência pessoal - "a percepção de uma pessoa sobre suas capacidades de realizar uma atividade tende a melhorar se suas experiências anteriores lhe proporcionarem informações positivas sobre as competências similares" (GUIMARÃES \& ABBAD, 2015, p. 173); (ii) observação vicária - "ao observar pessoas semelhantes a si mesmo obtendo sucesso mediante esforço pessoal, aumenta a crença dos observadores de que eles também possuem a capacidade de dominar suas habilidades necessárias para obter sucesso naquela situação" (GUIMARÃES \& ABBAD, 2015, p. 173); (iii) persuasão verbal - "as pessoas que são persuadidas verbalmente a acreditar que possuem capacidade de realizar as atividades com sucesso são suscetíveis a mobilizar um maior esforço e mantê-lo do que se abrigarem em dúvidas e se debruçarem sobre deficiências pessoais quando surgem problemas" (GUIMARÃES \& ABBAD, 2015, p. 173); (iv) foco emocional - os indivíduos têm mais possibilidade de desenvolver expectativas de sucesso "se não revelarem uma alta ansiedade referente a um determinado objeto social ou situação. [...]isso ocorre ao reduzir as reações das pessoas ao estresse e ao alterar uma interpretação negativa sobre o estado emocional ou físico do sujeito" (GUIMARÃES \& ABBAD, 2015, p. 173).

Além dessas fontes, as experiências interpessoais e contextuais vivenciadas pelo diretor também auxiliam na realização das tarefas administrativas e pedagógicas, vez que a ação é uma consequência direta do que e como eles pensam, embora também sejam influenciados por outros indivíduos (FISHER, 2011).

Guerreiro-Casanova e Russo (2016), investigam as relações preditivas entre a autoeficácia de gestores escolares e os aspectos pessoais, de atividade docente e do contexto relacionado à atividade dos gestores escolares. Os autores assinalam que o controle sobre as atribuições administrativas e pedagógicas depende da liberdade de ação percebida pelos diretores escolares, pois, ao se sentirem mais eficazes, tendem a reconhecer que as tarefas de administração geral sofrem influências externas, como das ações políticas e da comunidade em que a escola está inserida, mas que as tarefas pedagógicas podem ser controladas por eles próprios.

De acordo com Russo (2017), em pesquisa que explica como o constructo de autoeficácia ajuda a entender o engajamento de alguns indivíduos com a política, 
o nível de autoeficácia é fundamental para o "estabelecimento de metas, para a aquisição das qualidades necessárias para completar certa tarefa e, mais importante, para como alguém reagirá diante dos obstáculos na realização de tal tarefa" (RUSSO, 2017, p. 136).

Dessa forma, parece bastante razoável considerar como hipótese a investigar na pesquisa em tela a influência direta que a autoeficácia do diretor pode ter no uso dos dados do SIMADE, implicando na maior eficiência na realização das atividades rotineiras da gestão e promovendo a agregação de maior valor às práticas dos diretores.

Pode-se considerar então que as rotinas administrativas e pedagógicas, bem como a autoeficácia do diretor, envolvem tanto aspectos da escola como de seus integrantes que influenciam no planejamento e execução de ações no contexto escolar.

$\mathrm{Na}$ presente pesquisa, essa fundamentação teórica ofereceu o respaldo necessário para ajustar e criar novas questões para os instrumentos de coleta de dados junto aos atores escolares - diretores, secretários e ATBs. A seguir, será apresentada a versão final do questionário aplicado nas escolas da rede pública estadual de Minas Gerais.

\subsection{Quadro geral dos questionários aplicados nas escolas estaduais de Minas Gerais}

Após a finalização dos instrumentos, estes foram enviados por e-mail para seis pareceristas de diferentes instituições, dentre os quais dois (PUC-RIO ${ }^{80} \mathrm{e}$ $\mathrm{UNIRIO}^{81}$ ) que já haviam validado a primeira versão dos questionários aplicados no pré-teste em Juiz de Fora; dois da $\mathrm{UFJF}^{82}$; um de um IFE $^{83}$ e um do SENAC ${ }^{84}$; selecionados por terem orientado pesquisas que dialogam com o tema do estudo em

\footnotetext{
${ }^{80}$ Professora do Departamento de Educação da PUC-Rio - Gilda Helena Bernardino de Campos

${ }^{81}$ Professora do Departamento de Educação da Unirio - Ana Cristina Prado de Oliveira.

${ }^{82}$ Dois professores de programas de pós-graduação em Educação da Universidade Federal de Juiz de Fora (UFJF): um do mestrado profissional em educação do Centro de Políticas Públicas e Avaliação da Educação da Universidade Federal de Juiz de Fora (CAEd/UFJF) - Luis Antônio Fajardo Pontes; e o outro do mestrado em Educação da UFJF - Cassiano Caon Amorim.

${ }^{83}$ Uma assessora pedagógica do Instituto Federal de Educação, Ciência e Tecnologia de Minas Gerais, Campi Bambuí que ministrou cursos de formação para gestores escolares no CAEd Luciana da Silva de Oliveira.

${ }^{84}$ Assessor Técnico do SENAC/Departamento Nacional, que em sua pesquisa de doutorado aplicou um questionário sobre liderança dos gestores escolares - Anderson Córdova Pena.
} 
tela ou por suas experiências profissionais e acadêmicas relacionadas à aplicação de questionários e a gestão escolar.

Após a avaliação dos dois questionários, eles sugeriram: (i) que as perguntas sobre a etapa e a quantidade de alunos fossem retiradas das avaliações em larga escala (SIMAVE ou Prova Brasil), ao invés de se tornarem questões fechadas; (ii) que, na questão sobre as condições de uso dos recursos, seria interessante perguntar sobre computadores portáteis (principalmente tablets); (iii) mudanças no texto de apresentação dos questionários (indicar uma média de tempo para responder os instrumentos; e melhorar a forma de agradecimento ao final do questionário); (iv) ajustes gramaticais em algumas opções de respostas das perguntas; (v) nas perguntas que permitiam mais de uma resposta, a indicação dessa possibilidade no enunciado da questão; (vi) que as questões relacionadas ao tempo de atuação deveriam ser perguntas abertas. O Quadro a seguir apresenta a nova organização dos instrumentos, com as referências utilizadas na elaboração de cada dimensão e respectivas questões:

Quadro 2: Estrutura dos instrumentos aplicados na rede pública estadual mineira

\begin{tabular}{|c|c|c|c|}
\hline \multicolumn{4}{|c|}{ Questionários } \\
\hline Conceitos & $\begin{array}{l}\text { Questionário } \\
\text { do diretor }\end{array}$ & $\begin{array}{l}\text { Questionário } \\
\text { do Secretário }\end{array}$ & Referências \\
\hline Escola & Código; Nome da escola & Código; Nome da escola & Oliveira (2015) \\
\hline Infraestrutura & $\begin{array}{l}\text { *Na escola, como você } \\
\text { avalia o acesso; *Entre as } \\
\text { alternativas abaixo, informe } \\
\text { se a escola participa de } \\
\text { algum programa ou projeto? }\end{array}$ & $\begin{array}{l}\text { Quais as condições de uso dos } \\
\text { recursos de informática da escola? } \\
\text { *Entre as alternativas abaixo, } \\
\text { informe se a escola participa de } \\
\text { algum programa ou projeto? } \\
\text { *Na escola, como você avalia o } \\
\text { acesso: }\end{array}$ & $\begin{array}{l}\text { Bonamino (2012); } \\
\text { Alves e Franco } \\
\text { (2008); Martins e } \\
\text { Flores (2015); } \\
\text { Basniak \& Soares, } \\
\text { 2014; Almeida \& } \\
\text { Silva, 2011 }\end{array}$ \\
\hline $\begin{array}{l}\text { Agentes } \\
\text { escolares } \\
\text { (diretor e } \\
\text { secretário) }\end{array}$ & $\begin{array}{l}\text { Cargo; *Você pretende } \\
\text { continuar na direção desta } \\
\text { escola nos próximos anos?; } \\
\text { *Em relação a pergunta } \\
\text { anterior, registre os motivos } \\
\text { que o levam/levaram a essa } \\
\text { decisão: Sexo; Ano de } \\
\text { nascimento; Cor; } \\
\text { Trabalhou como docente; } \\
\text { tempo na função docência; } \\
\text { tempo na função de diretor } \\
\text { ou vice-diretor; tempo na } \\
\text { função desta escola; forma } \\
\text { de provimento do cargo; } \\
\text { *grau máximo de } \\
\text { escolarização concluída; } \\
\text { *curso da graduação; * } \\
\text { instituição em que cursou; } \\
\text { *curso de pós-graduação; }\end{array}$ & $\begin{array}{l}\text { Cargo; Sexo; Ano de nascimento; } \\
\text { Cor; * grau máximo de escolarização } \\
\text { concluída; *curso da graduação; * } \\
\text { instituição em que cursou; *curso de } \\
\text { pós-graduação; trabalhou como } \\
\text { docente; tempo na função docência; } \\
\text { tempo na função de secretária; } \\
\text { tempo como secretária desta escola; } \\
\text { forma de provimento do cargo; } \\
\text { Você pretende continuar na } \\
\text { secretaria desta escola nos próximos } \\
\text { anos? Informe por qual motivo } \\
\text { pretende ou não permanecer na } \\
\text { secretaria desta escola? }\end{array}$ & $\begin{array}{l}\text { Oliveira (2015); } \\
\text { Polon (2012); Leite } \\
\text { e Lima (2015) } \\
\text { SIMADE; } \\
\text { Esquisani e } \\
\text { Silveira (2015); } \\
\text { Oliveira e Paes de } \\
\text { Carvalho (2018); } \\
\text { Werle e Audino } \\
\text { (2015); Balduti } \\
\text { (2017); Abud } \\
\text { (2012); Simão e } \\
\text { Netto (2008); } \\
\text { Almeida et al } \\
\text { (2013); Oliveira e } \\
\text { Paes de Carvalho } \\
\text { (2015); Leal e } \\
\text { Novaes (2018); } \\
\text { Lessa e Teixeira } \\
\text { (2013) }\end{array}$ \\
\hline
\end{tabular}




\begin{tabular}{|c|c|c|c|}
\hline \multicolumn{4}{|c|}{ Questionários } \\
\hline Conceitos & $\begin{array}{l}\text { Questionário } \\
\text { do diretor }\end{array}$ & $\begin{array}{l}\text { Questionário } \\
\text { do Secretário }\end{array}$ & Referências \\
\hline $\begin{array}{l}\text { Fonte de } \\
\text { informação }\end{array}$ & $\begin{array}{l}\text { *Em seu cotidiano, quais são } \\
\text { as fontes de informação que } \\
\text { você utiliza para buscar } \\
\text { dados sobre a escola? }\end{array}$ & $\begin{array}{l}\text { *Em seu cotidiano, quais são as } \\
\text { fontes de informação que você } \\
\text { utiliza para buscar dados sobre a } \\
\text { escola? }\end{array}$ & $\begin{array}{l}\text { Massa et al, } \\
\text { (2018); Miranda } \\
\text { (2016); Ventura e } \\
\text { Nassif, (2016); } \\
\text { Moraes e Barbosa } \\
\text { (2015); Correia e } \\
\text { Ziviani, (2015); } \\
\text { Rodrigues \& } \\
\text { Blatimann (2014) }\end{array}$ \\
\hline TIC & $\begin{array}{l}\text { *Como você define seu nível } \\
\text { de conhecimento para } \\
\text { utilizar: }\end{array}$ & $\begin{array}{l}\text { *Como você define seu nível de } \\
\text { conhecimento para utilizar: }\end{array}$ & $\begin{array}{l}\text { Belloni (2003); } \\
\text { Vallin et al (2007) } \\
\text { Piedade e Pedro } \\
\text { (2014); Freire \& } \\
\text { Bastos Júnior } \\
\text { (2016) } \\
\end{array}$ \\
\hline $\begin{array}{l}\text { Formação } \\
\text { continuada }\end{array}$ & $\begin{array}{l}\text { *Nos últimos três anos, você } \\
\text { participou de alguma } \\
\text { atividade de formação } \\
\text { continuada? } \\
\text { * Caso tenha participado de } \\
\text { algum curso do SIMADE, } \\
\text { quais foram os assuntos } \\
\text { tratados? }\end{array}$ & $\begin{array}{l}\text { *Nos últimos três anos, você } \\
\text { participou de alguma atividade de } \\
\text { formação continuada? } * \text { Caso tenha } \\
\text { participado de algum curso do } \\
\text { SIMADE, quais foram os assuntos } \\
\text { tratados? }\end{array}$ & $\begin{array}{l}\text { Leite e Lima } \\
\text { (2015); Oliveira } \\
\text { (2015); Balduti } \\
\text { (2017) }\end{array}$ \\
\hline $\begin{array}{l}\text { Autoeficácia } \\
\text { do diretor }\end{array}$ & $\begin{array}{l}\text { Em sua função de diretor, o } \\
\text { quanto você consegue: }\end{array}$ & & $\begin{array}{l}\text { Guerreiro- } \\
\text { Casanova e Russo } \\
\text { (2016); Guerreiro- } \\
\text { Casanova (2014); } \\
\text { Guerreiro- } \\
\text { Casanova e Azzi } \\
\text { (2014); Iaochite } \\
\text { (2017); Iaochite et } \\
\text { al (2016) }\end{array}$ \\
\hline $\begin{array}{l}\text { Uso dos dados } \\
\text { do SIMADE }\end{array}$ & $\begin{array}{l}\text { *Você considera que os } \\
\text { dados do SIMADE são úteis } \\
\text { para: Indique com que } \\
\text { frequência você utiliza os } \\
\text { dados do SIMADE para: }\end{array}$ & $\begin{array}{l}\text { Quais os principais recursos } \\
\text { (funcionalidades) do SIMADE que } \\
\text { você utiliza em seu cotidiano? } \\
\text { *Você considera que os dados do } \\
\text { SIMADE são úteis para: } \\
\text { Indique com que frequência você } \\
\text { utiliza os dados do SIMADE para: }\end{array}$ & $\begin{array}{l}\text { Piedade e Pedro } \\
\text { (2014); Cruz } \\
\text { (2014); Silva et. al. } \\
\text { (2013); Fontanive } \\
\text { (2013); SIMADE; } \\
\text { Balduti (2017) }\end{array}$ \\
\hline $\begin{array}{l}\text { Uso do } \\
\text { SIMADE }\end{array}$ & $\begin{array}{l}\text { *Em seu cotidiano, você } \\
\text { utiliza o SIMADE? Se sim, } \\
\text { como?; *O SIMADE em } \\
\text { influenciado a organização } \\
\text { da escola? Se sim, como?; * } \\
\text { O SIMADE tem } \\
\text { influenciado a parte } \\
\text { pedagógica da escola? Se } \\
\text { sim, como?; *Do seu ponto } \\
\text { de vista, qual a contribuição } \\
\text { mais importante que o } \\
\text { SIMADE oferece para o seu } \\
\text { trabalho na escola? * Qual a } \\
\text { sua responsabilidade em } \\
\text { relação ao SIMADE? *Você } \\
\text { utiliza os dados do SIMADE } \\
\text { nas:; *Considerando o seu } \\
\text { trabalho na direção desta }\end{array}$ & $\begin{array}{l}\text { *Em seu cotidiano, você utiliza o } \\
\text { SIMADE? Se sim, como?; *O } \\
\text { SIMADE em influenciado a } \\
\text { organização da escola? Se sim, } \\
\text { como?; * O SIMADE tem } \\
\text { influenciado a parte pedagógica da } \\
\text { escola? Se sim, como?; } \\
\text { *Do seu ponto de vista, qual a } \\
\text { contribuição mais importante que o } \\
\text { SIMADE oferece para o seu trabalho } \\
\text { na escola? } \\
\text { *Com que frequência você acessa o } \\
\text { SIMADE? } \\
\text { Qual a sua responsabilidade em } \\
\text { relação ao SIMADE? } \\
\text { * Considerando o seu trabalho na } \\
\text { escola, marque qual é o seu nível de }\end{array}$ & $\begin{array}{l}\text { Piedade e Pedro } \\
\text { (2014); Roque e } \\
\text { Costa (2007); } \\
\text { SIMADE; Balduti } \\
\text { (2017) }\end{array}$ \\
\hline
\end{tabular}




\begin{tabular}{|c|c|c|c|}
\hline \multicolumn{4}{|c|}{ Questionários } \\
\hline Conceitos & $\begin{array}{c}\text { Questionário } \\
\text { do diretor }\end{array}$ & $\begin{array}{l}\text { Questionário } \\
\text { do Secretário }\end{array}$ & Referências \\
\hline & $\begin{array}{l}\text { escola, marque qual é o seu } \\
\text { nível de concordância com } \\
\text { cada uma das afirmativas } \\
\text { abaixo: }\end{array}$ & $\begin{array}{l}\text { concordância com cada uma das } \\
\text { afirmativas abaixo: } \\
\text { * O diretor acessa o SIMADE? * } \\
\text { Caso tenha respondido "Sim" na } \\
\text { pergunta anterior, informe para que } \\
\text { o diretor acessa ao SIMADE; *O } \\
\text { diretor solicita os dados do } \\
\text { SIMADE nas: }\end{array}$ & \\
\hline $\begin{array}{l}\text { Estilo de } \\
\text { gestão }\end{array}$ & $\begin{array}{l}\text { Em uma semana, quantas } \\
\text { horas você dedica; } \\
\text { Sobre o trabalho na direção } \\
\text { desta escola, marque qual é o } \\
\text { nível de concordância com } \\
\text { cada uma das afirmativas } \\
\text { abaixo: }\end{array}$ & $\begin{array}{l}\text { *Sobre o seu trabalho nesta escola, } \\
\text { marque qual é o seu nível de } \\
\text { concordância com cada uma das } \\
\text { afirmativas abaixo; } \\
\text { *Em uma semana, quantas horas o } \\
\text { diretor dedica para: }\end{array}$ & $\begin{array}{l}\text { Oliveira (2015); } \\
\text { Oliveira e Paes de } \\
\text { Carvalho (2015); } \\
\text { Penas e Soares } \\
\text { (2014) Pena } \\
\text { (2013); Soares e } \\
\text { Teixeira (2006); } \\
\text { Urick e Bowers } \\
\text { (2014); Marks e } \\
\text { Printy (2003) }\end{array}$ \\
\hline Clima escolar & $\begin{array}{l}\text { *Como você avalia os } \\
\text { seguintes aspectos da sua } \\
\text { escola? }\end{array}$ & $\begin{array}{l}\text { *Como você avalia os seguintes } \\
\text { aspectos da sua escola? }\end{array}$ & $\begin{array}{l}\text { Oliveira (2015); } \\
\text { Oliveira \& } \\
\text { Waldhelm (2016) }\end{array}$ \\
\hline Usabilidade & & $\begin{array}{l}\text { Marque qual é o seu nível de } \\
\text { concordância com cada uma das } \\
\text { alternativas abaixo sobre o } \\
\text { SIMADE: }\end{array}$ & $\begin{array}{l}\text { Roque e Costa } \\
\text { (2007); Iso 9126 } \\
\text { (2010) Campos e } \\
\text { Campos (2001); } \\
\text { Teixeira e } \\
\text { Valentim ( 2017); } \\
\text { Araújo, (2014); } \\
\text { Costa e Ramalho } \\
\text { (2010) }\end{array}$ \\
\hline $\begin{array}{l}\text { Atividades da } \\
\text { função }\end{array}$ & $\begin{array}{l}\text { Indique com que frequência } \\
\text { você realiza as seguintes } \\
\text { atividades no seu trabalho na } \\
\text { direção da escola; }\end{array}$ & $\begin{array}{l}\text { Indique com que frequência você } \\
\text { realiza as seguintes atividades no } \\
\text { seu trabalho na secretaria da escola: }\end{array}$ & $\begin{array}{l}\text { Oliveira (2015); } \\
\text { Polon (2012); Leal } \\
\text { e Novaes (2018) }\end{array}$ \\
\hline
\end{tabular}

Fonte: Elaboração própria.

Apenas os conceitos Autoeficácia do diretor e Estilo de gestão podem ser classificados como latentes, ou seja, "não são observados diretamente e passam por um processo de construção, que convenciona quais especificações irão compor seu conceito latente" (OLIVEIRA, 2015, p. 88), enquanto os demais, podem ser classificados como observáveis por serem medidos diretamente.

Os questionários, em sua integralidade, estão anexados ${ }^{85}$ ao final deste trabalho, bem como o quadro que apresenta os conceitos secundários e a classificação das variáveis dos questionários de diretor e secretário ${ }^{86}$. A seguir será

\footnotetext{
${ }^{85}$ Os questionários estão no anexo 4

${ }^{86}$ Anexo 5
} 
apresentado como foi realizada a seleção da amostra e a coleta de dados nas escolas públicas estaduais de Minas Gerais.

\subsection{A seleção da amostra e a coleta de dados nas escolas estaduais de Minas Gerais}

Segundo dados do Censo de 2016, a rede educacional de Minas Gerais atendeu a 4.658.750 alunos matriculados em creches, unidades de Educação Infantil, Ensino Fundamental I e II, Ensino Médio, Educação de Jovens e Adultos (EJA), nas modalidades presencial, semipresencial e educação a distância, e Educação Profissional concomitante, subsequente ou formação inicial ou continuada concomitante em relação ao Ensino Médio (FIC ${ }^{87}$ ). Em 2016, as matrículas estavam distribuídas da seguinte forma:

Tabela 2: Distribuição de matrículas nas redes públicas e privada de Minas Gerais.

\begin{tabular}{l|c|c|c|c|c|c}
\hline \multicolumn{1}{c|}{ Níveis e etapas } & \multicolumn{7}{c}{ Matrículas } \\
\hline & Estadual & Federal & Municipal & Privada & Total* & $(\mathbf{\%})$ \\
\hline $\begin{array}{l}\text { Educação Infantil (creche } \\
\text { e pré-escola) }\end{array}$ & 586 & 288 & 539.915 & 214.237 & 755.026 & $16,2 \%$ \\
\hline $\begin{array}{l}\text { Anos iniciais do Ensino } \\
\text { Fundamental }\end{array}$ & 385.770 & 1.040 & 818.290 & 182.656 & 1.387 .756 & $\mathbf{2 9 , 7 \%}$ \\
\hline $\begin{array}{l}\text { Anos finais do Ensino } \\
\text { Fundamental }\end{array}$ & $\mathbf{7 6 2 . 2 9 0}$ & 1.712 & 325.742 & 125.748 & 1.215 .492 & $26 \%$ \\
\hline $\begin{array}{l}\text { Ensino Médio (1 }{ }^{\mathbf{o}}, 2^{\mathbf{o}}, 3^{\mathbf{o}}, \\
4^{\mathbf{o}} \text { série e não seriado) }\end{array}$ & $\mathbf{7 2 9 . 5 2 4}$ & 19.946 & 6.331 & 79.288 & 835.089 & $17,9 \%$ \\
\hline EJA & 252.807 & 738 & 74.141 & 19.442 & 347.128 & $7,4 \%$ \\
\hline Educação Profissional & 6.914 & $\mathbf{4 2 . 8 0 1}$ & 1.820 & $\mathbf{6 6 . 7 2 4}$ & 118.259 & 2,5 \\
\hline Total & $\mathbf{2 . 1 3 7 . 8 9 1}$ & 66.525 & 1.766 .239 & 688.095 & 4.658 .750 & $100 \%$ \\
\hline
\end{tabular}

Fonte: Censo Escolar 2016 - Minas Gerais.

Total* representa as matrículas regulares, de Educação Especial, Educação Profissional e EJA em instituições públicas estadual, federal, municipal e também da rede privada de Minas Gerais.

Em Minas Gerais, as redes municipais concentram as matrículas da Educação Infantil e anos iniciais do Ensino Fundamental, enquanto que, nos anos finais do Ensino Fundamental e Ensino Médio, a quantidade de matrículas na rede estadual supera as demais redes. Essa é uma tendência nacional que segue a determinação da Lei de Diretrizes e Bases nº 9394/96 (título IV, artigos 10 e 11). No caso da Educação Profissional, merece destaque o número de matrículas nas redes federal e privada, que juntas respondem por $92,6 \%$ do total. Nos 853

\footnotetext{
${ }^{87}$ Cursos de qualificação profissional (formação inicial e continuada - FIC), de escolaridade mínima variada.
} 
municípios que compõem o Estado, há 16.550 unidades de ensino, sendo 74 da rede federal; 3.644 da rede estadual; 8.817 das redes municipais e 4.015 da rede privada.

No caso deste estudo, consideramos fundamental observar, dentro da escola, o posicionamento dos responsáveis pela gestão e dos usuários do sistema, secretários e ATBs, sobre o SIMADE. Nesse sentido, entre outubro de 2017 e janeiro de 2018, foram enviados, às 3644 escolas da rede pública estadual, inúmeros e-mails. Em cada envio, as escolas recebiam dois e-mails, um com o questionário a ser respondido pela equipe de gestão, ou seja, diretor ou vice-diretor, e outro pelo secretário ou Assistente Técnico de Educação Básica (ATB), responsável pelo SIMADE.

Inicialmente pretendíamos, se não fosse possível obter respostas da maior parte do universo pesquisado, alcançar pelo menos uma amostra representativa ${ }^{88}$ deste. Entretanto, após a análise do retorno dos questionários enviados em outubro e novembro de 2017, que contabilizava 370 unidades de ensino em que diretores e secretários/ATB responderam ao questionário, avaliamos que seria extremamente improvável obter um número expressivo de escolas da rede ou uma amostra estatisticamente significativa.

Realizamos novos esforços junto às escolas no mês seguinte, com o envio de e-mails se concentrando nas unidades de ensino em que somente o diretor ou secretário/ATB haviam respondido ao questionário. Ou seja, a partir de dezembro, cada escola recebeu apenas um e-mail, ou de diretor ou de secretário/ATB. Foram feitas também ligações para as escolas nos meses de dezembro e janeiro, porém, devido ao período de encerramento das atividades letivas e rodízio de funcionários, não obtivemos um retorno significativo de respostas dos questionários.

Optamos então por definir uma amostragem não probabilística ${ }^{89}$ aleatória por conveniência, - na qual os elementos da amostra são escolhidos devido à facilidade de comunicação e de colaboração, selecionando-se os membros mais acessíveis (OLIVEIRA, 2001). Como havia 216 escolas em que apenas os diretores haviam respondido o questionário e 306 em que apenas os secretários haviam

88 Numa amostragem aleatória simples, a probabilidade de um elemento da população ser selecionado é a mesma e a seleção é completamente ao acaso. Neste tipo de amostragem —cada elemento só pode ser selecionado uma vez, e a amostra é obtida aleatoriamente (OLIVEIRA, 2001). Ou seja, as 3.644 possuíam uma única chance de compor a amostra da pesquisa.

${ }^{89}$ Abordagem não probabilística aleatória: é aquela em que a seleção dos elementos da população para compor a amostra depende ao menos em parte do julgamento do pesquisador ou do entrevistador no campo. 
respondido, era necessário dedicar mais atenção a essas unidades de ensino, ao invés de buscar obter novas respostas e ampliar a situação de apenas o diretor ou secretário responder ao instrumento.

Cabe assinalar que, nesta pesquisa, o universo inicial de escolas estaduais, 3.644, foi reduzido para 3.444, o que corresponde a uma redução de 5,48\% no número de escolas, ou seja, 200 unidades de ensino foram retiradas do universo, pelas seguintes razões: (i) 14 escolas que tiveram suas atividades encerradas ${ }^{90}$ no ano de 2016 e não constavam na lista da SEE/MG disponibilizada para a pesquisa em outubro de 2017; (ii) 173 escolas que, segundo dados do Censo de 2016, não ofertam Ensino Fundamental e Ensino Médio na modalidade regular. Nesta pesquisa, só foram consideradas escolas que ofertam a educação básica na modalidade regular; (iii) 13 Postos Estaduais de Educação Continuada (PECON), isto é, postos avançados, em localidade de menor demanda, vinculados aos Centros de Educação Continuada $\left(\mathrm{CESEc}^{91}\right)$ das cidades próximas. Tanto os PECON quanto os CESEC, segundo dados do Censo de 2016, oferecem os anos finais do Ensino Fundamental e Ensino Médio na modalidade semipresencial, isto é, com aulas presenciais e a distância. Como nesta pesquisa só foram consideradas escolas que oferecem a educação básica na modalidade regular, os PECON foram retirados.

Nas escolas em que os Diretores/Secretários/ATBs responderam aos questionários, foram consideradas as respostas apenas dos instrumentos que tiveram praticamente todas as questões respondidas ${ }^{92}$. Nesse sentido, foram desconsiderados 256 questionários de diretor e 527 questionários de secretários, os quais estavam apenas com as questões iniciais respondidas (código e/ou nome da escola). Apenas 628 escolas estavam com os questionários completos. Nos casos de respostas duplicadas, seja no questionário do diretor ou no do secretário, consideramos apenas o questionário respondido primeiro ${ }^{93}$. Foram assim retiradas outras sete escolas. Das 621 restantes, a partir do nome da escola, foram desconsideradas respostas de mais 35 , pois observou-se que 18 delas eram CESEC,

\footnotetext{
${ }^{90}$ Vale destacar que, como trabalhamos com as informações presentes no Censo Escolar 2016 (dados mais recentes disponíveis no site do INEP), possivelmente, algumas dessas escolas foram fechadas ao término daquele ano e esta informação - embora já disponível na SEE-MG só constará no Censo 2017.

${ }^{91}$ Tanto o PECON como o CESEC oferecem a educação semipresencial.

${ }^{92}$ Missing aceitável foi de cerca de até $10 \%$.

${ }^{93}$ Por meio de um levantamento manual, realizado no Excel, a escola que já tinha respondido aos questionários era retirada da lista para novo envio de e-mail, então somente a resposta mais antiga era considerada.
} 
ou seja, não ofereciam ensino regular, cinco de educação especial, uma técnica industrial $^{94}$, e 11 escolas que não constavam no Censo de 2016, o que indica que foram abertas recentemente, provavelmente em 2017, e tinham, em princípio, pouca experiência de uso do SIMADE.

Dessa forma, de um total de 884 respostas do questionário do diretor e 1.155 do questionário do secretário considerando questionários completos e incompletos, obtivemos, em janeiro de 2018, 586 respostas de escolas em que os dois profissionais responderam aos instrumentos e sobre as quais possuíamos informações do Censo Escolar 2016 e da SEE-MG.

A amostra final, 586 escolas, composta pela junção do método de amostragem aleatória simples e amostragem não aleatória por conveniência não é representativa da população. Porém, representa um subconjunto da população - de 3444 unidades de ensino -, formado por elementos passíveis de obtenção de informação relevante para os propósitos da presente investigação.

${ }^{94}$ É uma instituição de ensino técnico profissional. 


\section{A AMOSTRA CONSIDERADA NESTE TRABALHO: o uso dos dados do SIMADE}

Os pontos de partida para as análises sobre o uso dos dados do SIMADE foram os dados da Prova Brasil 2015 e do Censo Escolar 2016, os quais foram utilizados para descrever as características das escolas. A base de dados da pesquisa é composta pelos dados dos 586 questionários respondidos pelos diretores e secretários das escolas estaduais mineiras, aos quais foram agregados os dados os dados do Censo Escolar 2016 e os resultados de proficiência do SIMAVE e da Prova Brasil 2015 relativos as mesmas escolas. Em seguida, apresentamos a estatística descritiva das questões relacionadas aos sujeitos, à infraestrutura e ao acesso ao SIMADE a partir da forma como os respondentes relatam utilizar o sistema em seu cotidiano.

\subsection{Características das escolas}

As escolas estaduais de Minas Gerais situadas na zona rural e nos distritos representam 26,1\% do total; e as escolas com questionários respondidos somam $22,1 \%,{ }^{95}$ indicando que, embora as respostas tenham se concentrado na zona urbana sede dos municípios, houve um percentual razoável de respostas da zona rural e dos distritos e, em particular neste último caso o percentual específico ficou bastante próximo da distribuição estadual. As cidades onde estão situadas as SRE, que são aquelas que possuem o maior número de escolas estaduais, foram também as que apresentaram o maior número de questionários respondidos.

No que tange ao porte dos municípios, foram adotadas, nesta pesquisa, as considerações propostas por Silva (2013), segundo as quais a delimitação de número de habitantes ${ }^{96}$ indica o porte da cidade. Apenas nos municípios de pequeno porte, embora concentrem um número elevado de escolas estaduais, obtivemos uma quantidade de respostas substantivamente inferior em termos percentuais $(39,2 \%)$ nas escolas com questionário respondido em comparação aos 57,9\% nas escolas estaduais de Minas Gerais. Por outro lado, nos municípios de médio e grande porte

\footnotetext{
95 Todas as tabelas referentes a características das escolas se encontram no anexo 6

${ }^{96}$ Foi considerada como cidade de pequeno porte aquela que possuía até 50.000 habitantes; de médio porte as cidades que tinham entre 50.000 e 500.000 habitantes; de grande porte aquelas com mais de 500.000 habitantes.
} 
o percentual de escolas alcançado pela pesquisa (nesta ordem, 41,6\% e 19,1\%) superou em quase $20 \%$ o percentual total de escolas da rede estadual, respectivamente, $31,5 \%$ e $10,6 \%$.

No que concerne às etapas atendidas, os segmentos ofertados nas escolas estaduais de Minas Gerais e nas escolas com questionários respondidos encontramos distintas formas de combinação desses segmentos, conforme apresentado na tabela a seguir:

Tabela 3: Segmentos atendidos pelas escolas

\begin{tabular}{l|c|c|c|c}
\hline \multirow{2}{*}{ Segmentos oferecidos } & \multicolumn{2}{|c|}{ Escolas Estaduais de MG } & \multicolumn{2}{c}{$\begin{array}{l}\text { Escolas com questionários } \\
\text { respondidos }\end{array}$} \\
\cline { 2 - 5 } & $\mathbf{N}$ & $\mathbf{\%}$ & $\mathbf{N}$ & $\mathbf{\%}$ \\
\hline Apenas Ensino Fundamental I & $\mathbf{4 0 7}$ & $\mathbf{1 1 , 8}$ & $\mathbf{8 2}$ & $\mathbf{1 4 , 0}$ \\
\hline Educação Infantil e Ensino Fundamental I & 6 & 0,2 & 0 & 0,0 \\
\hline Apenas Ensino Fundamental II & 138 &, 0 & 18 & 31 \\
\hline Ensino Fundamental I e II & $\mathbf{5 9 4}$ & $\mathbf{1 7 , 2}$ & $\mathbf{8 3}$ & $\mathbf{1 4 , 2}$ \\
\hline $\begin{array}{l}\text { Educação Infantil, Ensino Fundamental I e } \\
\text { II }\end{array}$ & 3 & 0,1 & 0 & 0,0 \\
\hline Apenas Ensino Médio & 224 & 6,5 & 48 & 8,2 \\
\hline Ensino Fundamental I e Ensino Médio & 7 & 0,2 & 2 & 0,3 \\
\hline Ensino Fundamental II e Ensino Médio & $\mathbf{1 1 1 7}$ & $\mathbf{3 2 , 4}$ & $\mathbf{1 9 6}$ & $\mathbf{3 3 , 4}$ \\
\hline $\begin{array}{l}\text { Ensino Fundamental I e II e Ensino } \\
\text { Médio }\end{array}$ & $\mathbf{9 3 9}$ & $\mathbf{2 7 , 3}$ & $\mathbf{1 5 7}$ & $\mathbf{2 6 , 8}$ \\
\hline $\begin{array}{l}\text { Educação Infantil, Ensino Fundamental I e } \\
\text { II e Ensino Médio }\end{array}$ & 9 & 0,3 & 0 & 0,0 \\
\hline Total & 3444 & 100,0 & 586 & 100,0 \\
\hline
\end{tabular}

Fonte: Elaboração própria a partir dos dados do Censo Escolar 2016.

As etapas apresentam uma grande diversidade de configurações e arranjos, embora seja menos expressivo o número de escolas que atendem a apenas um segmento, isto é, especificamente, apenas ao Ensino Fundamental II, anos finais, ou apenas ao Ensino Médio. A exceção das escolas que oferecem apenas um segmento são aquelas com apenas o Ensino Fundamental I, pois possuem os percentuais mais expressivos, com 11,8\% referente às escolas estaduais de Minas Gerais e $14 \%$ das escolas com questionários respondidos.

É relevante o percentual de escolas que oferecem dois segmentos, com destaque para o Ensino Fundamental I e II, que corresponde a 17,2\% das escolas estaduais de Minas Gerais e a 14,2\% nas unidades de ensino com questionários respondidos. Nas escolas estaduais de Minas Gerais, predominam as unidades de ensino que oferecem Ensino Fundamental II e Ensino Médio, com 32,4\%, percentual muito próximo das escolas com questionários respondidos com as mesmas características $(33,4 \%)$. Também no caso das escolas que oferecem três 
segmentos, Ensino Fundamental I e II e Ensino Médio, os percentuais encontrados no conjunto da rede estadual $(27,3 \%)$ e no conjunto das escolas que responderam aos questionários $(26,8 \%)$ se mostrou igualmente próximo.

Quanto às demais combinações, observamos que apresentam os menores percentuais tanto das escolas estaduais de Minas Gerais, quanto nas que responderam aos questionários, ressaltando que em alguns casos (escolas com Educação Infantil, Ensino Fundamental I e II e escolas com Educação Infantil, Ensino Fundamental I e II e Ensino Médio - num total de 12 em toda a rede estadual) elas sequer integram o universo de questionários respondidos.

Podemos observar que a maioria das escolas possuem dois segmentos, sendo o Ensino Fundamental II - anos finais - e o Ensino Médio as etapas que predominam. Em seguida se destacam as escolas com três segmentos, especificamente, Ensino Fundamental completo e Ensino Médio. Essa característica da rede se mantém quando observamos as matrículas por segmentos:

Tabela 4: Estatísticas descritivas de matrículas, segundo segmentos oferecidos.

\begin{tabular}{|c|c|c|c|c|c|c|c|c|c|c|}
\hline \multirow[b]{2}{*}{$\begin{array}{l}\text { Segmento } \\
\mathrm{s} \\
\text { oferecidos }\end{array}$} & \multicolumn{5}{|c|}{ Escolas Estaduais de MG } & \multicolumn{5}{|c|}{$\begin{array}{l}\text { Escolas com questionários } \\
\text { respondidos }\end{array}$} \\
\hline & $\begin{array}{l}\mathrm{N} \\
\text { Escol } \\
\text { as }\end{array}$ & $\begin{array}{l}\text { Média de } \\
\text { Matrícul } \\
\text { as p/ } \\
\text { escola }\end{array}$ & DP & $\begin{array}{l}\mathrm{Mi} \\
\mathrm{n}\end{array}$ & Max & $\begin{array}{l}\mathrm{N} \\
\text { Escol } \\
\text { as }\end{array}$ & $\begin{array}{l}\text { Média de } \\
\text { Matrícul } \\
\text { as p/ } \\
\text { escola }\end{array}$ & DP & $\begin{array}{l}\mathrm{Mi} \\
\mathrm{n}\end{array}$ & Max \\
\hline $\begin{array}{l}\text { Apenas } \\
\text { Ensino } \\
\text { Fundamen } \\
\text { tal I }\end{array}$ & 407 & 403,00 & $\begin{array}{c}198,8 \\
7\end{array}$ & 41 & $\begin{array}{c}120 \\
0\end{array}$ & 82 & 444,00 & $\begin{array}{c}196,4 \\
0\end{array}$ & 49 & $\begin{array}{c}113 \\
7\end{array}$ \\
\hline $\begin{array}{l}\text { Apenas } \\
\text { Ensino } \\
\text { Fundamen } \\
\text { tal II }\end{array}$ & 138 & 436,22 & $\begin{array}{c}239,2 \\
3\end{array}$ & 51 & $\begin{array}{c}106 \\
0\end{array}$ & 18 & 370,44 & $\begin{array}{c}203,2 \\
1\end{array}$ & 69 & 891 \\
\hline $\begin{array}{l}\text { Ensino } \\
\text { Fundamen } \\
\text { tal I e II }\end{array}$ & 594 & 453,57 & $\begin{array}{c}286,7 \\
8\end{array}$ & 37 & $\begin{array}{c}187 \\
6\end{array}$ & 83 & 454,59 & $\begin{array}{c}278,2 \\
2\end{array}$ & 90 & $\begin{array}{c}187 \\
6\end{array}$ \\
\hline $\begin{array}{l}\text { Apenas } \\
\text { Ensino } \\
\text { Médio }\end{array}$ & 224 & 546,39 & $\begin{array}{c}484,1 \\
2\end{array}$ & 35 & $\begin{array}{c}204 \\
7\end{array}$ & 48 & 683,29 & $\begin{array}{c}499,4 \\
8\end{array}$ & 67 & $\begin{array}{c}204 \\
7\end{array}$ \\
\hline $\begin{array}{l}\text { Ensino } \\
\text { Fundamen } \\
\text { tal II e } \\
\text { Ensino } \\
\text { Médio }\end{array}$ & 1117 & 789,91 & $\begin{array}{c}403,0 \\
5\end{array}$ & 41 & $\begin{array}{c}244 \\
4\end{array}$ & 196 & 809,11 & $\begin{array}{c}407,7 \\
6\end{array}$ & $\begin{array}{c}16 \\
0\end{array}$ & $\begin{array}{c}216 \\
4\end{array}$ \\
\hline $\begin{array}{l}\text { Ensino } \\
\text { Fundamen } \\
\text { tal I e II e } \\
\text { Ensino } \\
\text { Médio }\end{array}$ & 939 & 704,17 & $\begin{array}{l}445,8 \\
7\end{array}$ & 56 & $\begin{array}{l}419 \\
1\end{array}$ & 157 & 836,29 & $\begin{array}{l}464,3 \\
2\end{array}$ & $\begin{array}{l}14 \\
8\end{array}$ & $\begin{array}{l}278 \\
0\end{array}$ \\
\hline Total & 3444 & & & & & 586 & & & & \\
\hline
\end{tabular}

Fonte: Elaboração própria a partir dos dados do Censo Escolar 2016. 
As escolas que apresentam apenas um dos segmentos do Ensino Fundamental possuem as menores médias e os menores valores máximos de matrícula tanto nas escolas estaduais de Minas Gerais quanto nas unidades de ensino que responderam aos questionários. Já as escolas com Ensino Fundamental I e II têm um maior quantitativo de matrículas do que as com apenas um segmento, que pode ser percebido pela média e dispersão entre os valores mínimo e máximo. Por outro lado, estas unidades escolares com Ensino Fundamental I e II são mais encontradas tanto nas escolas estaduais de Minas Gerais quanto nas unidades de ensino com questionários respondidos, do que escolas com apenas um segmento. Novamente há destaque para as escolas que oferecem o Ensino Fundamental II e Ensino Médio, seguidas daquelas com Ensino Fundamental I e II e Ensino Médio que, como mostram os dados descritivos de matrícula da tabela 4, são as que apresentam as maiores médias de matrícula tanto nas escolas da rede estadual mineira quanto nas escolas com questionários respondidos.

No que tange à análise do número de matrículas, a partir dos dados do Censo Escolar de 2016, consideramos apenas o número de matrículas das escolas, isto é, sem levar em consideração nenhuma classificação das unidades de ensino. Nesse sentido, as escolas estaduais de Minas Gerais possuem maior dispersão entre os valores máximo, 4191, e mínimo, 9, do que as escolas com questionários respondidos, respectivamente, 2780 e 49 . Soma-se a isso a média de 630 matrículas nas escolas estaduais de Minas Gerais e 691 nas escolas com questionário respondido. Esses resultados indicam que as escolas estaduais de Minas Gerais possuem, via de regra, mais matrículas. Pode-se propor a hipótese de que essas matrículas sejam, em sua maioria, do Ensino Fundamental II e Ensino Médio e Ensino Fundamental I e II e Ensino Médio, uma vez que são essas as características dominantes em termos de atendimento nas escolas da rede.

Em relação ao funcionamento da escola, especificamente no que concerne ao funcionamento em cada turno, nas escolas estaduais de Minas Gerais, 98,6\% das escolas funcionam no turno matutino, $95,8 \%$ no vespertino e $52,3 \%$ no noturno, ao passo, que nas escolas que responderam aos questionários, $99 \%$ funcionam no turno matutino, $95,1 \%$ no vespertino e $54,3 \%$ no noturno ${ }^{97}$. Esses resultados indicam que

\footnotetext{
${ }^{97}$ No anexo 6 está a tabela que apresenta as escolas que funcionam em 1, 2 e 3 turnos tanto nas escolas estaduais de Minas Gerais quanto nas escolas com questionários respondido.
} 
predominam escolas que funcionam no turno matutino, seguida de escolas que funcionam no turno vespertino.

No que concerne ao número de professores por escola, a média nas escolas estaduais de Minas Gerais é de 34 professores, ao passo que, nas escolas com questionário respondido, é de 36 docentes. Todavia, tanto as escolas estaduais de Minas Gerais quanto as escolas com questionários respondidos apresentam significativa dispersão, vez que os valores mínimo e máximo estão demasiadamente distantes da média.

\subsubsection{As avaliações em larga escala}

No que se refere à participação na Prova Brasil de 2015, foram consideradas duas dimensões: (i) para a participação no $5^{\circ}$ ano, apenas as escolas que oferecem o primeiro segmento do Ensino Fundamental; (ii) para a participação no $9^{\circ}$ ano, apenas as escolas que oferecem o segundo segmento do Ensino Fundamental. Na Prova Brasil de 2015, 1965 escolas estaduais de Minas Gerais participaram da aplicação das provas para o $5^{\circ}$ ano e 2800 no $9^{\circ}$ ano. Já as escolas com questionário respondido, no $5^{\circ}$ ano a participação foi de 324 unidades escolares e no $9^{\circ}$ ano 454 . Esses resultados indicam que, no estado de Minas Gerais, o quantitativo de escolas que ofertam o $9^{\circ}$ ano do Ensino Fundamental tem participação mais expressiva na Prova Brasil ${ }^{98}$.

Para analisar a proficiência, foi escolhida a disciplina de Matemática devido ao caráter tipicamente escolar do conhecimento matemático, em comparação com o conhecimento da língua nativa, que, necessariamente, é desenvolvido nos diversos ambientes frequentados pelos estudantes (FRANCO et al, 2007). Pela proficiência em Matemática na Prova Brasil, tanto no $5^{\circ}$ ano (escolas de Minas Gerais 227,38 e com questionário respondido 228,35) quanto no $9^{\circ}$ ano do Ensino Fundamental (escolas de Minas Gerais 256,13 e com questionário respondido 254,43), observamos que os alunos das escolas com questionário respondido apresentam proficiência média similar aos alunos das escolas estaduais de Minas Gerais.

\footnotetext{
98 Todas as tabelas estão no anexo 6
} 
O nível de escolaridade dos pais ${ }^{99}$, utilizado como proxy de Nível Socioeconômico (NSE) para as escolas estaduais de Minas Gerais e para as escolas com questionários respondidos, considerou para o $5^{\circ}$ ano apenas as unidades de ensino que oferecem o primeiro segmento do Ensino Fundamental. Já para o $9^{\circ}$ ano, apenas escolas que oferecem o segundo segmento do Ensino Fundamental. Ou seja, as informações de percentual de pais do $5^{\circ}$ ano com alta escolaridade referem-se apenas às escolas que possuem Ensino Fundamental I e as informações de percentual de pais do $9^{\circ}$ ano com alta escolaridade dizem respeito somente às escolas que possuem Ensino Fundamental II. Além disso, nesta análise, foram considerados como referência os pais com nível de escolaridade Ensino Médio ou Ensino Superior, isto é, o resultado indica a proporção de pais com tal nível educacional.

No $5^{\circ}$ ano do Ensino Fundamental a média foi de 0,527 para as escolas estaduais de Minas Gerais e 0,545 para as unidades de ensino com questionários respondidos, ao passo que no $9^{\circ}$ ano do Ensino Fundamental foi, respectivamente, 0,437 e 0,460 . A diferença de 1,8 pontos percentuais no caso dos alunos do $5^{\circ}$ ano e de 2,3 pontos percentuais no caso do $9^{\circ}$ ano, ao observamos as médias, mostra a semelhança entre os dois grupos analisados.

Em relação aos dois grupos, quando analisamos o tempo que os diretores estão na gestão, observamos que:

Tabela 5: Tempo na direção desta escola

\begin{tabular}{|c|c|c|c|c|}
\hline \multirow{2}{*}{ 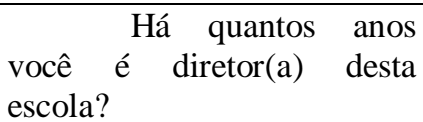 } & \multicolumn{2}{|c|}{ Escolas Estaduais de } & \multicolumn{2}{|c|}{$\begin{array}{l}\text { Escolas } \\
\text { questionários respondidos }\end{array}$} \\
\hline & $\mathrm{N}$ & $\%$ & $\mathrm{~N}$ & $\%$ \\
\hline Menos de um ano & 274 & 9,8 & 46 & 9,4 \\
\hline $1-2$ anos & 272 & 9,7 & 45 & 9,2 \\
\hline 3-5 anos & 1150 & 40,9 & 210 & 42,9 \\
\hline 6-10 anos & 543 & 19,3 & 89 & 18,2 \\
\hline 11-15 anos & 442 & 15,7 & 81 & 16,6 \\
\hline 16-20 anos & 114 & 4,1 & 17 & 3,5 \\
\hline Mais de 20 anos & 14 & 0,5 & 1 & 0,2 \\
\hline Total & 2809 & 100,0 & 489 & 100,0 \\
\hline Missing & $411 *$ & & $49 * *$ & \\
\hline
\end{tabular}

* Como 224 escolas estaduais de Minas Gerais oferecem apenas o Ensino Médio, não teriam como responder essa questão que foi extraída da Prova Brasil, de maneira que o universo de escolas que poderia responder tal pergunta é 3220.** Como 48 escolas com questionários respondidos oferecem apenas o Ensino Médio, não teriam como responder essa questão que foi extraída da Prova Brasil, de maneira que o universo de escolas que poderia responder tal pergunta é 538 .

99 Foi considerada a maior escolaridade entre o pai e a mãe da criança, declarados no questionário do aluno da Prova Brasil de 2015 
Nas escolas estaduais de Minas Gerais e nas escolas com questionário respondido, 19\% dos diretores estão a menos de dois anos na unidade de ensino e aproximadamente $40 \%$ estão entre três e cinco anos na direção da escola. Os que estão entre 6 e 10 anos na direção da escola representam cerca de $19 \%$ e os com entre 11 e 15 anos, aproximadamente $16 \%$. Os com mais de 16 anos na gestão da mesma escola são apenas cerca de $4 \%$.

Portanto, segundo os dados da Prova Brasil de 2015 e considerando a duração do mandato de quatro anos, a maioria dos diretores estava no final da primeira gestão ou no início da segunda, pois os percentuais mais significativos estão na categoria entre 3 e 5 anos. Esse dado é compatível com a legislação mineira vigente, a qual dispõe que o diretor e/ou vice-diretor atuante na função durante o processo de escolha de diretor poderá se recandidatar uma única vez.

Considerando que as características da oferta educacional de cada unidade escolar em termos de segmentos atendidos, turnos e número de matrículas e professores, impacta a gestão administrativa e pedagógica da escola, incluímos também na base de dados o indicador de complexidade de gestão ${ }^{100}$. A construção do indicador de complexidade de gestão ${ }^{101}$ está associada a quatro fatores, que podem ser mensurados a partir dos dados do Censo Escolar: (a) quantidade de turnos que a escola oferece; (b) porte da escola, a partir do número de matrículas; (c) número de etapas/modalidades ofertadas pela escola; (d) etapas ofertadas pela escola que atenderiam, teoricamente, a alunos com idade mais elevada (SOARES \& ALVES, 2013). Quanto maior o valor dessas variáveis, maior será a complexidade da gestão.

Para este estudo, a importância do indicador de complexidade da gestão se fundamenta na possibilidade de se obter uma visão mais ampla da gestão escolar, ao reduzir características do funcionamento da escola a uma forma sintética. Além disso, conforme já observado por Alves e Xavier (2016), o indicador pode ser mais eficaz na descrição da realidade, do que quando se busca encontrar tendências em

\footnotetext{
${ }^{100} \mathrm{O}$ indicador de complexidade da gestão foi criado com base no indicador já existente e divulgado pelo MEC.

${ }^{101}$ Para saber mais sobre os níveis, consulte a Nota Técnica Complexidade da Gestão. Disponível em:

http://download.inep.gov.br/informacoes_estatisticas/indicadores_educacionais/2014/escola_comp lexidade_gestao/no ta_tecnica_indicador_escola_complexidade_gestao.pdf Acesso em: $15 / 01 / 2018$.
} 
variáveis isoladas. No presente trabalho refizemos as análises para o cálculo do indicador de complexidade de gestão com base nos procedimentos descritos na nota técnica do INEP à respeito. Dessa forma, repetimos com o nosso conjunto de dados a análise fatorial para o cálculo do indicador de complexidade da gestão:

\begin{tabular}{|c|c|}
\hline Variáveis & $\begin{array}{l}\text { Cargas } \\
\text { Fatoriais }\end{array}$ \\
\hline Quantidade de turnos que a escola oferece & 0,884 \\
\hline Porte da escola, a partir do número de matrículas & 0,638 \\
\hline $\begin{array}{l}\text { Número de etapas/modalidades ofertadas pela } \\
\text { escola }\end{array}$ & 0,899 \\
\hline $\begin{array}{l}\text { Indicador de qual das etapas ofertadas pela escola } \\
\text { atenderiam, teoricamente, alunos com idade mais } \\
\text { elevada }\end{array}$ & 0,893 \\
\hline $\mathrm{KMO}^{102}$ & 0,761 \\
\hline Alpha de Cronbach ${ }^{103}$ & 0,811 \\
\hline
\end{tabular}

A partir dos valores resultantes da análise fatorial, foram formados quatro grupos de análise, considerando 1 desvio padrão abaixo e 1 desvio padrão acima da média, sendo que, quanto maior o valor, mais complexa é a gestão da escola. Os níveis são: (a) nível 1 - valores menores que 1 desvio padrão abaixo da média; (b) nível 2 - valores entre 1 desvio padrão abaixo da média e a média; (c) nível 3 valores entre a média e 1 desvio padrão acima da média; (d) nível 4 - valores maiores de 1 desvio padrão acima da média. As escolas presentes no grupo 4 são aquelas que apresentam maior complexidade na gestão. A seguir, a tabela apresenta o indicador de complexidade da gestão das escolas cujos diretores e secretários responderam ao nosso survey:

\footnotetext{
${ }^{102}$ Indica a proporção da variância dos dados que pode ser considerada comum a todas as variáveis, isto é, que pode ser atribuída a um fator. Quanto mais próximo de 1 mais adequada é a amostra à aplicação da análise fatorial.

${ }^{103}$ Estima a confiabilidade, ou seja, mede a correlação entre respostas em um questionário através da análise das respostas dadas pelos respondentes. Seus valores variam entre zero e 1 e a confiabilidade é tanto maior quanto mais perto de 1 estiver o valor da estatística.
} 
Tabela 7: Distribuição de escolas, segundo grupamento e análise de níveis de complexidade de gestão.

\begin{tabular}{l|c|c}
\hline \multirow{2}{*}{ Níveis de complexidade da gestão } & \multicolumn{2}{c}{ Escolas da amostra } \\
\cline { 2 - 3 } & $\mathbf{N}$ & $\mathbf{\%}$ \\
\hline Nível 1 & 125 & 21,3 \\
\hline Nível 2 & 152 & 25,9 \\
\hline Nível 3 & 157 & 26,8 \\
\hline Nível 4 & 152 & 25,9 \\
\hline Total & 586 & 100,0 \\
\hline Fonte: Elaboração própria a partir dos microdados do Censo Escolar 2016.
\end{tabular}

Nos dois grupos pouco mais da metade das escolas apresentam níveis mais elevados de complexidade de gestão, isto é, níveis 3 e 4 embora as escolas com questionário apresente percentual ligeiramente mais alto (52,7\%). No que se refere à distribuição das escolas por SRE, nos dois grupos os polos regionais Centro e Vale do Aço são os que se destacam em relação ao número de escolas, respectivamente, $24,3 \%$ e 23,1\% nas escolas estaduais de Minas Gerais e 37,9\% e 15,5\% nas unidades de ensino com questionário respondido.

Finalmente, cabe ressaltar que, de modo geral, as 586 unidades de ensino que responderam ao questionário se assemelham às 3.444 escolas de Minas Gerais no que se refere à localização, porte do município e distribuição por SRE, turno de funcionamento das escolas e predominância de escolas que ofertam o Ensino Fundamental II e Ensino Médio e Ensino Fundamental I, Ensino Fundamental II e Ensino Médio - embora diferenças pontuais, como o número de turmas, matrículas e complexidade da gestão se façam presentes. Como temos mais características que se assemelham do que se diferem, podemos afirmar que as 586 escolas são um "espelho" do universo de 3.444 unidades de ensino da rede estadual de Minas Gerais.

\subsubsection{Características dos sujeitos}

Ao todo, 1172 profissionais da rede pública estadual de Minas Gerais distribuídos em 586 escolas responderam aos questionários ${ }^{104}$. Dentre a equipe diretiva, 93,3\% exercem a função de diretor escolar, e apenas 6,7\% ocupam a função de vice-diretor. Na equipe da secretaria da escola, 68,6\% dos respondentes

\footnotetext{
104 Para a análise descritiva (frequência, medianas, médias, desvio padrão, valores mínimos e máximos), foram utilizadas todas as respostas válidas, aspecto que explica eventuais alterações de $\mathrm{N}$ ao longo do texto.
} 
exercem a função de secretário escolar e 31,4\% são Assistentes Técnicos de Educação Básica (ATB), sendo $80 \%$ dos secretários e ATBs concursados ${ }^{105}$.

Os diretores são os responsáveis por representar oficialmente a escola, sendo o profissional que realizada a gestão geral da unidade de ensino, executando funções predominantemente administrativas e pedagógicas (LEAL \& NOVAES, 2018). Subordinados ao diretor estão os funcionários da secretaria escolar secretário(s) e ATB(s) ${ }^{106}$ - que são os responsáveis pela documentação, escrituração, atendimento ao público, vida escolar dos alunos, dados dos funcionários, observando a legislação aplicável em cada situação. Entretanto, há diferenças na função de secretários e ATBs, vez que os últimos são subordinados aos primeiros. Isto é, enquanto os secretários realizam atividades de coordenação da secretaria, como, por exemplo, distribuir as tarefas da secretaria escolar entre os ATBs; organizar e manter atualizados a coletânea de legislação, resoluções, instruções normativas, ordens de serviço, ofícios e demais documentos; e elaborar relatórios e processos de ordem administrativa a serem encaminhados às autoridades competentes, os ATBs são responsáveis pela escrituração dos históricos escolares, boletins, etc.; classificar, protocolar e arquivar documentos e correspondências; e organizar a documentação dos alunos, etc.

Entre os respondentes, as mulheres predominam, com um percentual de 87,7\%, que corresponde a 514 secretárias e ATBs; e, na direção da escola, a participação feminina é de 72,1\% (411 diretoras e vice-diretoras). Esse dado confirma a expressiva presença feminina no campo da educação escolar, conforme apontado por vários estudos (LEITE \& LIMA, 2015; LESSA \& TEIXEIRA, 2013), o que também evidencia que as mulheres têm assumido não apenas os cargos de docência dentro das escolas.

No que diz respeito à cor, o resultado dos diretores é semelhante ao já constatado em algumas pesquisas (OLIVEIRA \& PAES DE CARVALHO, 2015), pois há predominância da cor branca $(50,5 \%)$, seguida da parda $(41,1 \%)$. Já o resultado da equipe da secretaria da escola é inverso, com a predominância da cor parda $(49,3 \%)$ seguida da branca $(40,8 \%)$. Entretanto, chama a atenção o número de diretores, secretários e ATBs da cor preta, apenas $7 \%$.

\footnotetext{
105 Todas as tabelas do item 3.1.2 Características dos sujeitos estão no anexo 7

106 O número de secretários e ATBs varia conforme o número de alunos da escola.
} 
A média de idade dos integrantes da equipe da secretaria escolar secretários e ATB - é de 46 anos, enquanto a dos diretores e vice-diretores é 48 anos, embora as faixas etárias que predominam sejam a de 41 a 50 anos $(39,9 \%$ diretor e 44,4\% secretário e ATB) e de 51 a 60 anos (38,6\% diretor e 27,8\% secretário). Os profissionais mais novos em ambos os cargos têm 22 anos e os mais antigos chegam até 72 anos. 52,2\% dos secretários e ATB e 96,7\% dos diretores já trabalharam como regentes na educação básica.

A equipe da secretaria da escolar - secretários e ATBs - possui em média mais tempo atuando na função, 13 anos, e na escola, 9 anos, do que atuando como docente, 8 anos. Embora saibamos que a aprendizagem da profissão se dê como um processo contínuo, as experiências formativas adquiridas no período da docência (NASCIMENTO \& REIS, 2017) também podem contribuir para o desenvolvimento profissional do secretário e ATB escolar, possibilitando um maior entendimento sobre o aspecto pedagógico, uma vez que, segundo Abud (2012), esse profissional é um dos que fazem a mediação entre a parte pedagógica e administrativa da escola.

Os diretores, por outro lado, possuem mais tempo de experiência como docentes, com uma média de 15 anos, ao passo que atuando na direção de escola e na direção da escola atual (em que participa do survey), a média é de menos de 2 anos. Como cada mandato dura quatro anos, esses diretores e vice-diretores estão em seu primeiro ou segundo mandato, enquanto os secretários estão há mais de dois mandatos na escola. Em outras palavras, os secretários e ATBs são mais experientes na função do que os diretores, conforme apresentado na tabela abaixo:

Tabela 8: Tempo na função.

\begin{tabular}{|c|c|c|c|c|}
\hline \multirow{2}{*}{ Tempo de atuação na função } & \multicolumn{2}{|c|}{ Diretores e Vice-diretores } & \multicolumn{2}{|c|}{ Secretários e ATBs } \\
\hline & $\mathbf{N}$ & & $\mathbf{N}$ & $\%$ \\
\hline Até 3 anos & 235 & $41,3 \%$ & 192 & $32,8 \%$ \\
\hline 3 a 10 anos & 238 & $41,8 \%$ & 173 & $29,6 \%$ \\
\hline 11 a 20 anos & 92 & $16,2 \%$ & 158 & $27,0 \%$ \\
\hline Acima de 20 anos & 4 & $0,7 \%$ & 62 & $10,6 \%$ \\
\hline Total & 569 & $100 \%$ & 585 & $100 \%$ \\
\hline
\end{tabular}

Constata-se que há uma rotatividade dos diretores na rede estadual de Minas Gerais, uma vez que os maiores percentuais estão no período que compreende dois 
mandados, entre três e dez anos. ${ }^{107} \mathrm{O}$ mesmo resultado pode ser observado em relação aos secretários e ATBs, embora os percentuais acima de onze anos na função representem cerca de $30 \%$. Tais resultados podem estar relacionados à própria legislação vigente em Minas Gerais, que permite a permanência do diretor por dois mandatos e a do secretário indefinidamente já que se trata de um cargo de confiança do diretor.

No que concerne à escolarização dos diretores, secretários e ATBs, cerca de $80 \%$ desses profissionais responderam ter concluído o curso de graduação em instituição de ensino superior privada. A tabela a seguir apresenta mais detalhes sobre a escolarização:

Tabela 9: Escolarização dos respondentes.

\begin{tabular}{lll}
\hline Escolaridade & Diretor & Secretário \\
\hline Até o Ensino Médio & - & $19,8 \%$ \\
Ensino Superior & $25,4 \%$ & $43,9 \%$ \\
Especialização & $71,1 \%$ & $35,7 \%$ \\
Mestrado & $3,2 \%$ & $0,4 \%$ \\
Doutorado & $0,4 \%$ & $0,2 \%$ \\
& $\mathrm{~N}=570$ & $\mathrm{~N}=560$ \\
& Faltante $=16$ & Faltante $=26$ \\
\hline Fonte: Questionários do diretor e secretário escolar. & \\
Questionário do diretor - Casos válidos: $570(97,2 \%)$. Missing: $16(2,9 \%)$ \\
Questionário do secretário: Casos válidos: $560(95,5 \%)$. Missing: $26(4,4 \%)$
\end{tabular}

Os resultados dos secretários e ATBs seguem uma tendência já observada por Simão e Netto (2008) ao afirmarem que esses profissionais exercem uma atividade técnica que não exigiria formação superior, explicando por que alguns secretários e ATBs possuem escolaridade até o Ensino Médio ${ }^{108}$. Dos que concluíram apenas o ensino superior ${ }^{109}$, cerca de $50 \%$, se formaram em cursos voltados para a área de educação como Pedagogia (16,3\%), Letras (10\%), Matemática $(7,5 \%)$ e Biologia $(4,6 \%)$, sendo a exceção os graduados em Administração (6,7\%). Esse resultado vai ao encontro dos critérios para ocupação

107 Durante as entrevistas para validação dos dados dos questionários, um dos entrevistados mencionou que assumiu o cargo por causa de licença de saúde da diretora e que por isso ele poderia se candidatar mais duas vezes para diretor. Ou seja, caso isso aconteça ele poderá ficar mais de dez anos na direção.

${ }^{108}$ Sendo que, 0,2\% cursaram apenas o Ensino Fundamental, 5,7\% fizeram o curso de Magistério (Normal), de nível médio, e 13, 9\% curso Médio com formação técnica, ou antigo Segundo Grau. ${ }^{109}$ A questão sobre o curso de graduação concluído foi respondida por 463 secretários/ATBs, porém, 224 estavam em branco ou com informações incompatíveis com a pergunta. Portanto, consideramos 239 respostas. 
do cargo de secretário, ou seja, ser professor ou especialista da escola, levando-nos à hipótese de que os formados em administração sejam os ATBs.

Os diretores são, majoritariamente, graduados em Pedagogia e Matemática, respectivamente cerca de $8 \%$ e 6\%, Biologia, Letras e História, cerca de 5\% cada ${ }^{110}$. Entretanto, mesmo a graduação sendo majoritariamente para a docência, o que pode contribuir para a parte pedagógica da gestão, Santana et al. (2013), alertam que, em alguns casos, isso pode refletir em uma gestão amadora nas funções básicas de organizar, direcionar e controlar uma organização, isto é, em executar tarefas administrativas inerentes ao cargo de diretor.

No que concerne à pós-graduação, entre os secretários e ATbs, apenas $38,5 \%{ }^{111}$ possuem especialização lato sensu, sendo Educação Especial $(8,8 \%)$, Gestão Escolar (4,8\%) e Inspeção Escolar (5,7\%) os cursos com os maiores percentuais. Observa-se que prevalece a formação de pós-graduação em áreas educacionais, em detrimento de uma formação mais dirigida para a atual área de atuação. De acordo com Vieira et al. (2015), a procura por pós-graduação sem relação direta com a área de atuação pode estar associada a dois fenômenos: (i) plano de cargos, carreiras e salários que preveem promoção para os que cursam pósgraduação, independentemente da área de estudo; (ii) baixa oferta de cursos de pósgraduação mais voltados para a área de atuação. Como o plano de carreira de Minas Gerais, instituído pela Lei 15293 de 05/08/2004, prevê um aumento salarial para os profissionais com curso de pós-graduação, acreditamos que se trata da primeira opção apontada por Viera et al (2015).

Entre os diretores, conforme já apontado em inúmeros estudos (OLIVEIRA \& WALDHELM, 2016; OLIVEIRA \& PAES DE CARVALHO, 2018), predominam os que cursaram pós-graduação $(77 \%)^{112}$, sendo que $6 \%$ concluíram o curso de Gestão Escolar, 5,4\% de Supervisão, 4\% de Matemática, 3,7\% de Psicopedagogia e 3,1\% de Inspeção Escolar.

A formação continuada, compreendida por Leite e Lima (2015) como um processo constante de aprender a profissão, repensar as práticas e construir novos

\footnotetext{
110 A questão sobre o curso de graduação concluído pelo diretor foi respondida por 559 diretores, porém 306 estavam em branco ou com informações incompatíveis com a pergunta. Portanto, consideramos 253 respostas. Também cabe assinalar que há grande variabilidade dos cursos informados pelos diretores, ocasionando percentuais tão baixas nas maiores respostas.

$11138 \%$ de um total de 264 secretários e ATBs com pós-graduação.

$11277 \%$ correspondem a 451 diretores com pós-graduação.
} 
conhecimentos por meio de estudo, reflexão, discussão e confrontação de diferentes experiências profissionais, parece ter mais chances de ser consolidada na formação dos diretores escolares do que na dos secretários e ATBs. Isso porque, nos últimos três anos, apenas $40 \%$ dos secretários e ATBs participaram de cursos na área de secretaria escolar, enquanto $57,2 \%$ dos diretores cursaram programas de formação continuada.

Leite e Lima (2015) ainda afirmam que o elevado número de diretores com formação em nível de pós-graduação mostra o movimento recente de incentivo à formação desses profissionais realizados pelo governo federal, como por exemplo o Programa Escolas de Gestores ${ }^{113}$, que em Minas Gerais foi executado de 2010 a 2014. O inventivo da rede estadual de Minas Gerais para a formação dos diretores ocorreu, por exemplo, por meio de parcerias com o governo federal como no Programa de Capacitação a Distância para Gestores Escolares (Progestão), até 2014, e com o CAEd permitindo que os diretores possam participar do Mestrado Profissional em Gestão e Avaliação da Educação Pública, desde 2015.

Quanto à forma de provimento do cargo, em Minas Gerais, o processo para escolha de diretor é composto por seleção e eleição. Erasto Mendonça (2001) estudou como os sistemas de ensino de estados, distrito federal e municípios se organizaram em relação ao princípio constitucional da gestão democrática e menciona que essa forma de provimento do cargo tende a promover uma escolha mais consistente pois fundamenta-se na seleção dos melhores candidatos que possuem competência técnica para o cargo para posteriormente submetê-los à apreciação da comunidade escolar, evitando, assim, a interferência política em relação aos ocupantes do cargo, historicamente tão presente no Brasil.

Essa forma de provimento, segundo Santos e Prado (2014), possibilita maior participação, "pois além dos candidatos garantirem suas habilidades e competências para atuarem nas escolas, passarão por uma eleição, que demonstrará o quanto a sociedade o respalda" (SANTOS \& PRADO, 2014, p. 44). Entre os diretores, 49,1\% afirmam que o provimento do cargo é composto pelas duas etapas - seleção e eleição -, enquanto $45,4 \%$ só consideraram a etapa da eleição. O primeiro percentual vai ao encontro do que está estabelecido no edital SEE $n^{\circ} 03 / 2015$, que

\footnotetext{
${ }^{113} \mathrm{O}$ objetivo é a formação continuada de gestores escolares, por meio de cursos de aperfeiçoamento e especialização, com intuito de desenvolver práticas de gestão que contribuam para a aprendizagem discente, favoreçam o trabalho coletivo e a transparência na gestão escolar (FNDE, 2018).
} 
dispõe sobre as normas do processo de Certificação Ocupacional de Diretor Escolar e também das recomendações legais sobre a participação democrática estabelecida na Constituição Federal de 1988 e na LDB nº 9394/96.

Para o segundo percentual, considera-se a hipótese de que o fato de o processo de escolha de diretores da rede estadual mineira ser composto de três etapas - certificação ocupacional (prova), eleição e nomeação pelo governo (indicação) - ocasione certa confusão sobre a forma de acesso ao cargo. Hipótese semelhante à encontrada nos dados dos diretores pode ser apontada em relação aos secretários e ATBs, uma vez que o provimento legalmente previsto para o cargo é indicação do diretor e posterior ratificação pela SEE/MG. Entretanto, as respostas indicam a compreensão da pergunta como solicitação da informação sobre seu acesso ao cargo que ocuparam inicialmente na rede estadual - professor, supervisor escolar, ATB, etc. - que se deu por meio de concurso público $(52,2 \%)$ ou contrato (15,5\%). Outra hipótese em relação aos dados dos secretários/ATBs é o fato de estarem há mais tempo na função, como mencionado anteriormente, o que pode se justificar por serem funcionários efetivos, ou seja, aprovados em concurso público e por várias gestões reconduzidos ao cargo de secretário.

De acordo com Oliveira e Paes de Carvalho (2018, p. 5), cabe aos diretores "administrar o projeto pedagógico da escola, as pessoas que constituem a comunidade escolar e os aspectos físicos e financeiros da organização escolar”. Em relação ao cotidiano, os diretores e vice-diretores que trabalham, respectivamente, 40h e 30h semanais, são os responsáveis por representar oficialmente a escola por meio de diversas ações, tais como: adotar medidas para elevar a qualidade do ensino; fortalecer a autonomia; ter compromisso com a aprendizagem dos alunos; estimular o desenvolvimento profissional da equipe escolar; promover uma gestão participativa; fortalecer a comunicação entre a comunidade e a escola; etc. (MINAS GERAIS, 2008).

Dessa forma, esses profissionais dedicam seu tempo a diferentes tipos de atribuições sendo, conforme já apontado em algumas pesquisas (WERLE \& AUDINO, 2015; FORMIGA \& BARBOSA, 2007; SANTANA et al., 2013; LEAL \& NOVAES, 2018), marcadamente divididas entre pedagógico e administrativo. Nesta pesquisa, compreendemos que a dimensão administrativa engloba atribuições como prestação de contas, coleta de orçamentos, organização de horários e controles financeiros. Já a dimensão pedagógica se refere a atribuições como 
discussões sobre o currículo, avaliação, metodologia de ensino, análise de desempenho, disciplina e comportamento dos alunos.

A tabela a seguir apresenta as horas trabalhadas pelos diretores e vicediretores em relação à sua dedicação às dimensões administrativas e pedagógicas:

Tabela 10: Dedicação dos diretores e vice-diretores aos tipos de gestão.

\begin{tabular}{lcc}
\hline & Gestão administrativa & Aspectos pedagógicos \\
\hline Entre 1 e 5h & $8,2 \%$ & $8,9 \%$ \\
De 11 a 20h & $62,1 \%$ & $60,9 \%$ \\
De 21 a 30h & $13,5 \%$ & $15,7 \%$ \\
Mais de 30h & $15,4 \%$ & $13,8 \%$ \\
Não se aplica & $0,9 \%$ & $0,7 \%$ \\
Total & $100 \%$ & $100 \%$ \\
\hline
\end{tabular}

Fonte: Questionário do diretor.

Casos válidos: 586 (100\%)

Apesar dos diretores afirmarem que dedicam metade de sua carga horária semanal, representada pela opção de $11 \mathrm{~h}$ a 20h, para a gestão pedagógica e gestão administrativa, essa última apresenta um percentual ligeiramente maior. Esse resultado é semelhante ao encontrado por Leal e Novaes (2018) quando analisam como os diretores identificam as atribuições pedagógicas que lhes são demandadas para desenvolver a gestão das escolas. Leal e Novaes (2018) afirmam que esses profissionais são os instrumentos balizadores para o desenvolvimento educacional, pois dedicam considerável parte do seu tempo à dimensão administrativa, devido à grande demanda das atividades burocráticas dentro da escola, em razão das consequências geralmente pelos resultados imediatos dessa dimensão e seu grande impacto no funcionamento cotidiano da unidade de ensino. Por outro lado, é bastante comum o repasse da responsabilidade pedagógica para outros profissionais, como, por exemplo, o supervisor ou coordenador escolar. Ogawa e Filipak (2013) afirmam que a priorização da dimensão administrativa pode estar eventualmente também relacionada à capacitação prévia ou em serviço desses profissionais, que pode privilegiar conteúdos relacionados à legislação, questões administrativas e financeiras.

Fica a hipótese de que a própria estrutura organizacional das escolas da rede estadual de Minas Gerais (diretor, vice-diretor e supervisor escolar) pode estar contribuindo para esse resultado, vez que o este último se dedica integralmente aos aspectos pedagógicos, possibilitando que os diretores e vice-diretores fiquem por conta das questões administrativas. 
Mesmo assim, segundo Leal e Novaes (2018), a dimensão pedagógica requer sensibilidade dos diretores no processo de construção do conhecimento (ensino e aprendizagem). Ribeiro (2012) destaca a tensão presente no desenvolvimento das atribuições dos diretores nessa dimensão uma vez que a intervenção pedagógica pode ou não afetar positivamente o ensino e a aprendizagem. Do que pudemos apreender das respostas obtidas nesta investigação, talvez possamos afirmar que, em Minas Gerais, o cotidiano dos diretores é marcadamente dividido entre as duas dimensões.

Já os secretários e ATBs, por outro lado, realizam frequentemente a leitura das legislações e orientações educacionais da SEE/MG (73,4\%); asseguram que os dados dos alunos estejam corretos para migração para o Censo Escolar (Educacenso) (91,3\%). Cabe apenas aos secretários a leitura dos e-mails da escola (94,3\%); a distribuição do serviço da secretaria entre a equipe de ATBs (72,3\%); e a tomada de decisões em relação ao funcionamento da secretaria junto com o diretor(a) (77,1\%). Apesar de suas funções serem um elo entre os aspectos administrativo e pedagógico (ALMEIDA et al. 2013), nota-se uma maior dedicação às tarefas relacionadas ao aspecto administrativo, consoante com o perfil de suas atribuições legais. Esse resultado corrobora o que afirmam Almeida et al (2013), pois esses profissionais visam ordenar a estrutura administrativa da escola com vistas à realização das atividades de organização, controle de pessoal, recursos materiais e financeiros, auxiliando, indiretamente, nas atividades da área pedagógica.

Cabe ressaltar que os secretários e ATBs não são apenas executores de atividades burocráticas - arquivar documentos, responder ofícios, atender ao público, digitação de documentos, etc. - pois em suas mãos passam dados essenciais para pensar estrategicamente o processo pedagógico da escola, tais como notas, frequência, resultados finais. Em sua carga horária, de 30h semanais, esses profissionais estão em relação direta com diretores, supervisores, professores e alunos dentro da unidade de ensino, porém, apenas o secretário, com autorização do diretor, pode tomar decisões decisivas dentro da escola ${ }^{114}$, como por exemplo, contratar funcionários (ABUD, 2012).

\footnotetext{
${ }^{114}$ Como por exemplo realizar todo o procedimento para contratar profissionais da limpeza (Auxiliar de Serviço de Educação Básica - ASB) e professores.
} 
Cerca de $60 \%$ dos diretores, secretários e ATBs consideram que possuem uma boa relação de trabalho, sendo esta fundamental para o funcionamento da escola, vez que tanto a legislação (MINAS GERAIS, 2014), por meios das responsabilidades atribuídas aos ATBs e secretários, bem como a indicação das tarefas que esses profissionais realizam em seu cotidiano, apontam um vínculo entre o trabalho do diretor e dos secretários e ATBs.

Esse bom relacionamento também pode se refletir na permanência no cargo, vez que $93,8 \%$ dos secretários e ATBs afirmam desejar continuar na função e $84 \%$ dos diretores responderam que querem continuar na gestão da escola. Portanto, a avaliação positiva das relações entre secretários, ATBs e diretores pode estar indicando a qualidade dos relacionamentos, valores e atitudes partilhados entre os profissionais da escola (VINHA et. al., 2016). Oliveira e Waldhelm (2016) desenvolveram um estudo sobre a possível relação existente entre liderança do diretor, clima escolar - a partir da percepção dos professores - e o desempenho dos alunos da rede municipal e estadual do Rio de Janeiro. As autoras observaram que a "atmosfera" percebida pelos atores escolares está significativamente associada ao comportamento e a qualidade do trabalho (OLIVEIRA \& WALDHELM, 2016).

Dessa forma, a relação entre diretores e equipe da secretaria pode ser um aspecto que contribui positivamente para o desenvolvimento do trabalho desses atores em torno do SIMADE ao se referir a um forte alinhamento desses profissionais em relação à missão e à visão que compartilham sobre a unidade de ensino e ao tipo de uso que fazem do sistema. Nesta perspectiva, a equipe diretiva pode também desenvolver a colaboração para o uso dos dados, com vistas a construir de forma coletiva conhecimentos e hipóteses a respeito dos problemas que afetam a organização da escola e, indiretamente, a aprendizagem discente.

Analisamos, na próxima seção, a infraestrutura e a usabilidade do SIMADE a partir da perspectiva dos sujeitos da pesquisa.

\subsection{A infraestrutura tecnológica do SIMADE}

Inúmeras pesquisas têm realçado os benefícios que os sistemas de gestão escolar podem proporcionar para as unidades de ensino na organização dos dados acadêmicos, no gerenciamento das informações, (FREIRE \& BASTOS JÚNIOR, 2013; CALVANCANTE et al., 2016; SPECK et al., 2018) bem como para a gestão 
da escola como um todo ao promover maior agilidade nos procedimentos pedagógicos e administrativos e no processo de tomada de decisões (BALDUTTI, 2017; FONSECA, 2014).

Entretanto, para que isso realmente aconteça, é necessário que a infraestrutura física da escola seja adequada - prédio e instalações - o que, além de contribuir para melhorar o desempenho dos alunos (BONAMINO, 2012; ALVES \& FRANCO, 2008) também viabiliza o uso dos sistemas de gestão (SPECK et al., 2018). É necessário ainda ter uma boa estrutura tecnológica que compreenda a parte física - equipamentos e conexões de internet (VELANDIA et al., 2010; SANCHÉZ, 2017; MARTINS \& FLORES, 2015; BASNIAK \& SOARES, 2014), além de indivíduos que saibam usufruir das possibilidades dessa infraestrutura tecnológica. No suvey que aplicamos para coletar informações para esta tese, indagamos sobre os equipamentos e os acessos à internet e ao SIMADE e sobre a percepção dos profissionais de ensino em relação à infraestrutura e ao sistema.

\subsubsection{Os equipamentos e os acessos à internet e ao SIMADE}

Quanto à estrutura física, analisamos apenas a percepção dos secretários e ATBs $^{115}$ sobre o estado de conservação dos computadores da sala de direção e da secretaria da escola, vez que essas variáveis estavam presentes apenas no questionário do secretário. Mais de $80 \%$ dos respondentes indicaram que os equipamentos em ambos os casos estavam em bom estado de conservação e entre 13,8\% (no caso dos computadores de uso exclusivo da direção) e 15,1\% (no caso daquelas da secretaria) considerou que necessitavam de um pequeno reparo ${ }^{116}$. Tal resultado vai ao encontro das considerações de Baldutti (2017) e Tomaz (2015), que concluíram em suas pesquisas que o estado de conservação dos computadores não constitui um elemento crítico que impossibilita o uso do SIMADE.

No que diz respeito à percepção dos diretores, secretários e ATBs em relação ao acesso ao sistema:

\footnotetext{
${ }^{115}$ Essa questão constou apenas no questionário do secretário por serem eles os profissionais que dependem dos computadores e internet para executar suas atividades diárias.

${ }^{116}$ Todas as tabelas referentes ao item 3.2.1. Os equipamentos e os acessos à internet e ao SIMADE estão no anexo 8
} 
Tabela 11: Acesso ao SIMADE.

\begin{tabular}{ccc}
\hline & Secretário/ATB & Diretor \\
\hline Precário & $7,7 \%$ & $3,9 \%$ \\
Razoável & $28,6 \%$ & $24,2 \%$ \\
Bom & $12,9 \%$ & $56,6 \%$ \\
Excelente & $50,8 \%$ & $13,6 \%$ \\
\hline
\end{tabular}

Fonte: Questionário do Secretário - Casos válidos: 586 (100\%). Faltantes: $0(0 \%)$

Fonte: Questionário do diretor - Casos válidos: 577 (99, 4\%).

Faltantes: $9(1,5 \%)$

Entre $63,7 \%$ e 70,2\% dos secretários e diretores consideram o acesso excelente ou bom, embora os diretores apresentem um percentual menos elevado de avaliação (apenas 13,6\% considera excelente e 56,6\% considera bom) do que os secretários e ATBs (50,8\% consideram excelente e 12,9\% bom). Esse resultado é totalmente diferente do constatado por Tomaz (2015) e Fonseca (2014) em que cerca de $50 \%$ dos participantes das pesquisas (diretores e secretários), realizadas respectivamente em quatro e em trinta escolas estaduais de Minas Gerais, avaliavam a internet como regular, ruim ou péssima, sendo, segundo eles, um elemento dificultador do acesso e uso do SIMADE.

Em relação à frequência de acesso ao sistema, verificamos que 72,5\% dos diretores, segundo a equipe da secretaria, acessam o sistema. Esse resultado é corroborado pela questão "Em seu cotidiano, você utiliza o SIMADE? Se sim, como", a partir da qual se constatou que apenas 7,84\% dos diretores afirmaram não usar o sistema e cerca de $20 \%$ afirmam que o uso ocorre através dos funcionários da secretaria, ou seja, eles não o acessam diretamente. Em seu estudo, Balduti (2017) constata que apenas 40\% dos diretores acessam o sistema diariamente ou uma vez na semana.

O resultado que encontramos parece se coadunar com as respostas dadas pelos diretores sobre sua responsabilidade em relação ao uso do SIMADE ${ }^{117}$. Selecionamos algumas respostas ${ }^{118}$ para ilustrar a percepção dos diretores: (i) grupo de respostas 1 - "manter atualizado e os dados corretos para uma análise verdadeira e concreta"; "designar e supervisionar a ATB responsável e realizar algumas ações mais específicas quando necessário"; "acompanhar a inserção de dados fidedignos e sua constante atualização"; "fazer cumprir todas as ações inerentes ao mesmo,

\footnotetext{
${ }^{117}$ Questão número 35 do questionário do diretor e 36 do questionário do secretário.

${ }^{118}$ Essa questão possui como casos válidos 552 respostas $(94,1 \%)$ e missing de $34(5,8 \%)$.
} 
fiscalizando o acesso pelos ATBs e pontualidade na alimentação dos dados; "supervisionar, o serviço é realizado pela secretaria"; (ii) grupo de respostas 2 "abrir semanalmente juntamente com a equipe pedagógica para conferir frequência, evasão, desempenho pedagógico"; "monitorar os índices de evasão, abandono e desempenho discente e elaborar planos de metas e ações para intervenção com o apoio da supervisora escolar"; "verificar, junto à equipe pedagógica, as estratégias que devem ser feitas para melhor rendimento dos alunos e diminuir a evasão escolar".

Constatamos que os diretores percebem sua responsabilidade a partir de duas dimensões. A primeira, grupo de respostas 1, se refere à gestão do uso do sistema, na medida em que assumem um papel de supervisão, acompanhamento e fiscalização das ações, bem como da execução das tarefas realizadas pelos profissionais da secretaria da escola. A responsabilidade do diretor é técnica, visando apenas o cumprimento das atividades que devem ser realizadas no SIMADE. Pode-se afirmar que esta seria uma das facetas de uso do sistema enquanto instrumento de gestão administrativa.

Na segunda dimensão, grupo de respostas dois, o uso do sistema é voltado para a utilização dos dados inseridos no SIMADE, sendo o foco as informações que podem ser extraídas sobre os discentes. A responsabilidade do diretor é pedagógica, buscando, a partir dos dados sobre rendimento, desempenho, frequência, etc., melhorar a qualidade da educação. Tal resultado é semelhante ao observado nas pesquisas internacionais (DEMIR, 2006; BLAU \& PRESSER, 2013; CUNHA, 2013) em que os dados contribuem para a tomada de decisões no contexto escolar e o sistema é considerado como um instrumento de gestão pedagógica.

Portanto, em grande parte das escolas, ou seja, nas 525 unidades de ensino que compõem a dimensão $1^{119}$, há uma valorização do controle dos subordinados da secretaria para que esses executem as principais tarefas do sistema (inserção, alteração, etc.). No restante das unidades de ensino, isto é, em 27 unidades de ensino $^{120}$ que constituem a dimensão 2 a responsabilidade do diretor escolar abrange, além da verificação da realização das tarefas pelos secretários e ATBs, um "olhar" mais pedagógico em relação ao SIMADE e ao uso de seus dados. Na dimensão 2, o diretor parece monitor, a partir dos dados do SIMADE, os resultados

\footnotetext{
${ }^{119}$ Representa $89,4 \%$ das 586 escolas que compõem a amostra da pesquisa.

${ }^{120}$ Representa 4,6\% das 586 escolas que compõem a amostra da pesquisa.
} 
e frequência dos discentes que podem auxiliá-lo a melhorar a qualidade do ensino. E, pelos constatado nas respostas dos diretores, o SIMADE é um instrumento de gestão.

Em cerca de 5\% das escolas (27 unidade de ensino), portanto, parece que os diretores produzem uma nova regra que não se limita ao cumprimento sistemático e integral da resolução SEE n⿳ 1.180 de 28 de agosto de 2008 - que define sua responsabilidade na entrada e atualização periódica dos dados e na designação de servidor para utilizar o sistema - usando o SIMADE apenas para inserção e atualização de informações, mas também para usar seus dados para monitorar e tomar decisões dentro das unidades de ensino.

Outra questão sobre o acesso ao SIMADE ("Com que frequência você acessa o SIMADE?" ${ }^{121}$ ) nos permitiu verificar as respostas dos secretários, distribuída da seguinte forma:

\begin{tabular}{|c|c|}
\hline Frequência & \\
\hline Nunca & $0,3 \%$ \\
\hline Entre 1 e 3 vezes por mês & $2,7 \%$ \\
\hline Um vez por semana & $1,7 \%$ \\
\hline Duas vezes por semana & $2,0 \%$ \\
\hline Três vezes por semana & $2,5 \%$ \\
\hline Quatro vezes por semana & $4,6 \%$ \\
\hline Todos os dias & $79,6 \%$ \\
\hline Total & $100 \%$ \\
\hline
\end{tabular}

Esse resultado vai ao encontro do que já foi constatado anteriormente nas incursões exploratórias, nas quais secretário e/ou ATBs foram identificados como os principais usuários do sistema. Tal resultado se justifica pelas atribuições do próprio cargo, voltadas para a escrituração, registro e organização das informações (SANTANA, 2013). As respostas ${ }^{122}$ desses profissionais no que tange à sua responsabilidade em relação ao SIMADE, com respostas como: "acompanhar diariamente a alimentação do sistema"; "alimentar o sistema e gerar dados confiáveis"; "conferir e manter dados atualizados"; "digitação, acompanhamento

${ }^{121}$ Questão presente apenas no questionário do secretário porque nas incursões exploratórias da pesquisa foi constatado que a frequência de acesso do secretário é bem mais significativa do que a do diretor.

${ }^{122}$ Essa questão possui como casos válidos 549 respostas $(93,6 \%)$ e missing de $37(6,3 \%)$. 
de lançamentos. Cobranças de documentos"; "inserir corretamente e em tempo hábil os dados da escola"; "total, sou a responsável por fazer as inclusões/alterações necessárias"; e "todos os dias eu assino as documentações. [...] Portanto, a minha responsabilidade muitas vezes é de intermediar e reestruturar o trabalho do dia-adia".

Os secretários e ATBs percebem sua responsabilidade de forma bem diferente do diretor, uma vez que o foco é a realização de atividades voltadas para inserção, atualização, documentação condizente com a realidade da escola e com a legislação da SEE/MG, ou seja, não percebem sua responsabilidade voltada para a parte pedagógico da unidade de ensino. Dessa forma, as respostas só podem ser alocadas em um único grupo, denominado grupo de respostas da equipe da secretaria. O sistema é usado, portanto, para as tarefas do cotidiano que possibilitam o fornecimento de informações sobre alunos, professores, rendimento e desempenho escolar. Claramente o secretário ou ATB é o operador que executa as atividades do sistema para o diretor da escola.

Com a questão "Marque qual é o seu nível de concordância com cada uma das alternativas abaixo sobre o SIMADE" buscamos conhecer a avaliação do sistema do ponto de vista desses profissionais, considerando as categorias (já apresentadas no capítulo dois): usabilidade, eficiência, funcionalidade e confiabilidade. A tabela apresentada a seguir registra as respostas para todas as categorias: 
Tabela 13: Categorias - usabilidade, eficiência, funcionalidade e confiabilidade.

\begin{tabular}{|c|c|c|c|}
\hline Categoria & Variáveis & $\begin{array}{l}\text { Discordo em } \\
\text { parte ou } \\
\text { totalmente }\end{array}$ & $\begin{array}{l}\text { Concordo em } \\
\text { parte ou } \\
\text { totalmente }\end{array}$ \\
\hline \multirow{8}{*}{ Usabilidade } & $\begin{array}{l}\text { O SIMADE tem uma apresentação } \\
\text { agradável }\end{array}$ & $4,6 \%$ & $89 \%$ \\
\hline & $\begin{array}{l}\text { A forma e o tamanho das letras são } \\
\text { adequados }\end{array}$ & $5,9 \%$ & $87,7 \%$ \\
\hline & Os ícones/botões são fáceis de utilizar & $6,4 \%$ & $87,2 \%$ \\
\hline & $\begin{array}{l}\text { Encontro as informações com } \\
\text { facilidade }\end{array}$ & $12,1 \%$ & $81,5 \%$ \\
\hline & $\begin{array}{l}\text { Os textos do SIMADE são claros e } \\
\text { objetivos }\end{array}$ & $8,3 \%$ & $85,3 \%$ \\
\hline & $\begin{array}{l}\text { A interface do sistema (menus) } \\
\text { permite que alcance meus objetivos } \\
\text { facilmente }\end{array}$ & $12,4 \%$ & $81,2 \%$ \\
\hline & $\begin{array}{l}\text { É fácil aprender como funciona o } \\
\text { SIMADE }\end{array}$ & $10,4 \%$ & $83,2 \%$ \\
\hline & $\begin{array}{l}\text { Em geral, o SIMADE executa as } \\
\text { tarefas rapidamente }\end{array}$ & $34,3 \%$ & $59,3 \%$ \\
\hline \multirow{3}{*}{ Eficiência } & Confio no SIMADE & $8,5 \%$ & $85,1 \%$ \\
\hline & $\begin{array}{l}\text { As funcionalidades do } \\
\text { satisfazem totalmente } \\
\text { necessidades profissionais }\end{array}$ & $17,4 \%$ & $76,2 \%$ \\
\hline & $\begin{array}{l}\text { Estou satisfeito com o funcionamento } \\
\text { do SIMADE }\end{array}$ & $16 \%$ & $77,6 \%$ \\
\hline \multirow[t]{2}{*}{ Funcionalidade } & $\begin{array}{l}\text { Tenho dificuldade de salvar } \\
\text { informações no SIMADE }\end{array}$ & $49,8 \%$ & $43,8 \%$ \\
\hline & $\begin{array}{l}\text { As mensagens de erro do SIMADE } \\
\text { são claras }\end{array}$ & $37,8 \%$ & $55,8 \%$ \\
\hline \multirow[t]{2}{*}{ Confiança } & $\begin{array}{l}\text { As mensagens de erro do SIMADE } \\
\text { ajudam a solucionar os problemas }\end{array}$ & $36,6 \%$ & $57 \%$ \\
\hline & $\begin{array}{l}\text { O sistema não apresenta erros nem } \\
\text { interrupções na sua execução }\end{array}$ & $63,1 \%$ & 30,5 \\
\hline
\end{tabular}

Em relação à usabilidade, constatamos que a percepção dos usuários em relação ao SIMADE é positiva, vez que todos os itens apresentam os maiores percentuais para a resposta concordo em parte ou totalmente. Entretanto, em alguns itens - Encontro as informações com facilidade, A interface do sistema (menus) permite que alcance meus objetivos facilmente e É fácil aprender como funciona o SIMADE - apresentam percentuais mais elevados no percentual concordo em parte (cerca de 50\%) do que no concordo totalmente (cerca de 30\%). Esse resultado pode indicar a necessidade de se aprimorar a interface do sistema para que seu uso se torne mais fácil e intuitivo para o usuário.

Medeiros e Cybis (2000) alertam que "produtos com baixa usabilidade são, geralmente, responsáveis por frustrações, ansiedades, baixa produtividade e, em 
casos extremos, por abandono do software" (MEDEIROS \& CYBIS, 2000, s/p). Corrobora essa constatação a variável Tenho dificuldade de salvar informações no SIMADE, pertencente a categoria funcionalidade, na qual $34,1 \%$ dos respondentes concordam em parte com a afirmação e $9,7 \%$ concordam totalmente, indicando um problema na em relação a funcionalidade.

Em relação à categoria confiabilidade, o resultado é positivo, pois mesmo apresentando erros e interrupções na execução, na percepção dos secretários $(63,1 \%)$ as mensagens de erro ajudam a solucionar os problemas (57\%) e são claras $(55,8 \%)$. Como os equipamentos e a internet, na opinião dos secretários e ATBs, estão funcionando adequadamente nas escolas, emerge a hipótese de que existe algum problema na interface e/ou no funcionamento do sistema que está refletindo na usabilidade, funcionalidade, eficiência e confiabilidade do sistema. Vale lembrar, conforme observado por Roque e Costa (2007) que um sistema é considerado consistente quando todos os seus elementos respondem da forma que se espera.

Cabe ressaltar que a questão "Marque qual é o seu nível de concordância com cada uma das alternativas abaixo sobre o SIMADE" também evidenciou uma lacuna no questionário, vez que, conforme mencionado anteriormente, as respostas às quatro categorias indicaram necessidade de melhoria no sistema. Porém, o questionário não indagava ou deixa espaço para que os respondentes informassem quais seriam essas necessidades de melhorias.

No próximo tópico, analisamos se esses resultados têm influenciado a utilização do SIMADE pelos profissionais da escola.

\subsubsection{A formação dos recursos humanos para a utilização do SIMADE}

No que concerne à participação em cursos sobre o SIMADE, apenas 39,5\% dos diretores e 55,8\% dos secretários e ATBs afirmaram ter participado de algum curso nos últimos três anos ${ }^{123}$. Parece que nem todas as SREs de Minas Gerais, responsáveis pelos cursos do SIMADE, têm oferecido formação para os profissionais das escolas em relação ao SIMADE. Martins (2014) também assinala

\footnotetext{
${ }^{123}$ Todas as tabelas referentes ao item 3.2.2 A formação dos recursos humanos para a utilização do SIMADE está no anexo 8.
} 
essa lacuna em relação à formação dos profissionais para o uso do SIMADE, para o autor, as capacitações acontecem de forma esporádica para sanar dúvidas pontuais e são realizadas com uma carga horária insuficiente em relação à quantidade de informações a serem transmitidas.

Os cursos que foram ministrados pelas SREs versaram sobre os seguintes assuntos: cadastro, matrícula, enturmação, avaliação, frequência e histórico; dados de preenchimento obrigatório para migração para o Censo Escolar; emissão de declarações, boletins, atas e mapas de desempenho; criar pacote, programa pedagógico, cadastro de turma e encerramento do período letivo.

Embora somente os diretores, secretários e ATBs possam dar sentido às funcionalidades ensinadas no curso, indicando se seu uso será mais administrativo ou pedagógico no cotidiano da escola, todas as funcionalidades apresentadas nos cursos podem remeter ao acompanhamento do aluno em sua trajetória escolar. O curso com maior percentual de frequência de diretores e secretários ou ATBs (32,7\% e 47,9\% respectivamente) - cadastro, matrícula, enturmação, avaliação, frequência e histórico - ensinar a manter atualizados os dados básicos em relação à trajetória do aluno, como também a realizar o diagnóstico da escola a partir de informações extraídas da matrícula (aprovação ou reprovação), enturmação (turmas homogêneas ou heterogêneas), avaliação (notas, conceitos, parecer descritivo), frequência (evasão) e histórico (trajetória do discente ao longo dos anos), utilizando tais dados para elaborar ações pedagógicas preventivas ou de intervenção.

$\mathrm{O}$ curso sobre dados de preenchimento obrigatório de migração para o Censo Escolar parece ter se destacado ${ }^{124}$ porque é a partir dos dados sobre o número de alunos cadastrados no SIMADE que são realizados os repasses financeiros para a compra de merenda escolar, é definido o quantitativo de material e para a aplicação das provas dos SIMAVE, é feita a solicitação de transporte escolar, etc. Os demais cursos parecem ser oferecidos com menor frequência, provavelmente porque as atividades neles apresentadas são mais esporádicas, como a emissão de boletins, por exemplo, feita ao final do bimestre e a criação do programa pedagógico que ocorre, geralmente, no início do ano letivo.

A participação em cursos sobre o SIMADE pode também repercutir na percepção que os indivíduos têm sobre sua capacidade de executar tarefas usando

\footnotetext{
${ }^{124}$ Apresenta o maior número de respostas, 32,7\% dos diretores e 47,9\% dos secretários e ATBs.
} 
essa ferramenta e os recursos a ela associados. Nesse sentido, analisou-se o SIMADE na percepção dos diretores, secretários e ATBs, buscando identificar os níveis de conhecimento que esses profissionais apresentam para utilizar o sistema.

Gráfico 1: Nível de conhecimento para utilizar o SIMADE.

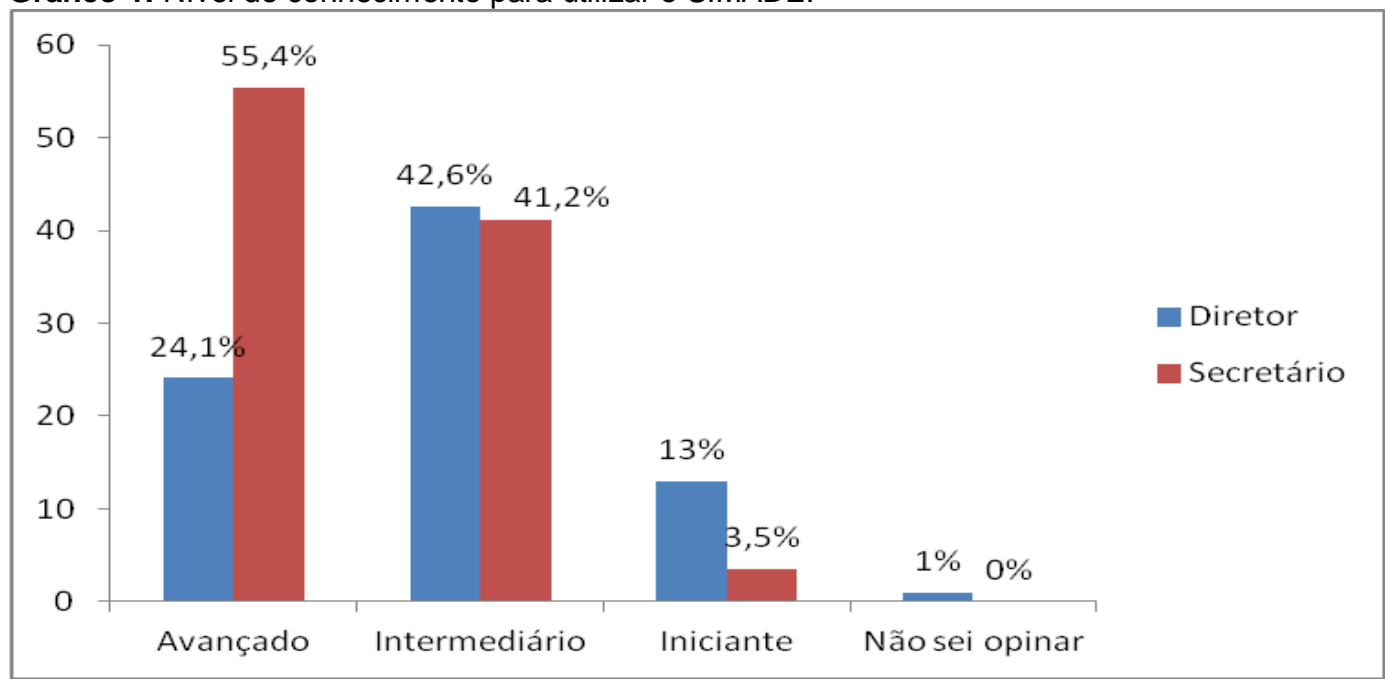

Fonte: Questionário do Secretário Escolar - Casos válidos: 549 (93,7\%). Faltantes: 37 (6,3\%). Fonte: Questionário do Diretor - Casos válidos: 577 (98,4\%). Faltantes: 9 (1,5\%).

O fato de os secretários e ATBs possuírem um nível mais elevado de conhecimento que os diretores em relação ao SIMADE, parece indicar que a equipe da secretaria da escola tem mais proficiência no uso do sistema, possivelmente porque inserir dados e preparar relatórios a partir do sistema esteja entre suas principais atribuições enquanto operadores na esfera administrativa da unidade escolar. Por outro lado, a relativa proximidade e a responsabilidade dos diretores com o SIMADE, expressa num nível intermediário de conhecimento poderia também ser considerada de maneira positiva, pois abrange as responsabilidades do diretor na escola.

Esse resultado deixa a hipótese, já observado por Guimarães e Abbad (2015), Alvarenga e Azzi (2010) e Filho \& Bellini (2014), sobre a possível correlação entre a formação para o uso do SIMADE e a autoeficácia computacional desses profissionais. De acordo com Guimarães e Abbad (2015), inspirados por Compeau e Higgins (1995), a autoeficácia computacional se refere à:

crença de um indivíduo quanto à sua própria capacidade de manipular os softwares e as tarefas inerentes ao manuseio do computador. Refere-se à autopercepção do indivíduo sobre a própria capacidade para organizar e implementar ações necessárias ao desempenho desejável, a fim de ter sucesso nessas tarefas específicas (GUIMARÃES \& ABBAD, 2015, p. 174). 
Indivíduos com maior nível de autoeficácia computacional trabalham de forma mais determinada e prolongada e percebem que a tecnologia é de fácil utilização, devido ao seu esforço, persistência e conhecimento (FILHO \& BELLINI, 2014). Também deixa a hipótese de que a frequência de acesso ao sistema pode estar influenciando a percepção que os profissionais têm em relação ao uso do SIMADE.

As análises descritivas apresentadas evidenciaram o perfil dos diretores, secretários e ATBs que atuam nas escolas estaduais de Minas, além de distinções em relação ao acesso e percepção de responsabilidade quanto ao SIMADE. A avaliação do sistema, aferida por meio das categorias funcionalidade, confiabilidade, usabilidade e eficiência, indica a necessidade de ajustes do SIMADE para que se alcance um reconhecimento totalmente positivo pelos usuários em relação à interface, execução, funcionalidades disponíveis e confiança no sistema.

Compreendendo que os diretores escolares podem ser mediadores do uso do SIMADE e, consequentemente, de seus dados em cada escola, cabe observar mais detidamente a atuação desses profissionais, especificamente as ações, atividades, motivações e significados que eles atribuem ao sistema. Nesse contexto, destacaremos o conhecimento e as experiências prévias desses atores, que podem influenciar tanto no uso do sistema como na utilização de seus dados. Além disso, onde há valores individuais existe exercício da discricionariedade por parte dos indivíduos, pois os treinamentos que receberam, o local onde estão inseridos e as relações estabelecidas são fatores que podem ampliar, limitar, direcionar, influenciar e até moldar as escolhas e ações dos sujeitos (LOTTA, 2015).

Nessa direção, pesquisas como a de Parra e Malta (2016) chamam a atenção para as crenças dos indivíduos, que também adquirem papel relevante no uso que este faz dos dados, em particular a autoeficácia, como já assinalamos dentre as hipóteses consideradas nesta pesquisa. No próximo tópico nos deteremos em analisar a autoeficácia do diretor e sua relação com os tipos de uso do SIMADE. 


\section{A AUTOEFICÁCIA DOS DIRETORES ESCOLARES}

De acordo com Iaochite (2017), parafraseando Bandura (1995), as novas realidades promovidas pela era da informação exigem do indivíduo "competências cognitivas avançadas e de autogerenciamento para dar conta da complexidade dos diferentes papéis da vida contemporânea" (IAOCHITE, 2017, p. 13). Essa aceleração do conhecimento e das mudanças tecnológicas, imersas em um ambiente abundante de informação em que o indivíduo deve ser capaz de entendê-las, interpretá-las e usá-las, requer que o sujeito se torne protagonista, isto é, um agente que age intencionalmente sobre as circunstâncias, elaborando planos de ação e estratégias na condução das diferentes esferas da própria vida (IAOCHITE, 2017).

No contexto escolar, os diretores são os responsáveis por um número significativo de atribuições, que correspondem às atividades de mobilizar e articular os requisitos materiais e humanos; e organizar, coordenar e acompanhar as ações dos funcionários administrativos, de apoio e, principalmente, do corpo docente, com o intuito de assegurar o avanço dos processos educativos das escolas, focalizando, simultaneamente nos direitos dos usuários finais do serviço (alunos e famílias) e nas necessidades dos diferentes atores escolares para agir de forma complementar e comprometida com o sucesso escolar de todos os alunos. Sua função é interativa, ou seja, está a serviço das pessoas e da organização (LEAL \& NOVAES, 2018), sendo esperado que ele seja um protagonista capaz de influenciar e mobilizar toda a comunidade escolar em torno de um projeto organizacional que atenda os direitos dos usuários do serviço de forma equânime.

Nesse contexto desafiador, segundo Iaochite e Costa Filho (2017) parafraseando Bandura (1997), a autoeficácia pode ser considerada como um elemento central para a motivação para a ação, pois "se as pessoas não acreditam que podem produzir os efeitos que desejam por meio de suas próprias ações, elas terão pouco incentivo para agir diante das dificuldades" (IAOCHITE \& COSTA FILHO, 2017, p. 98).

Enquanto construto derivado da Teoria Social Cognitiva, a crença ou julgamento da autoeficácia do diretor também influencia "a capacidade de desempenhar as funções cognitivas e comportamentais necessárias para orientar o processo grupal em direção à realização dos objetivos" (CASANOVA \& AZZI, 
2012, p. 2) e se constitui pela percepção do diretor em relação à própria capacidade de realizar as tarefas administrativas e pedagógicas que integram seu cotidiano na escola.

No que concerne à mensuração da autoeficácia do diretor escolar, a pesquisa de Tschannen-Moran e Gareis (2004) apresentou uma medida de autoeficácia válida e confiável usando uma escala de dezoito itens, que permitiu, através de análise fatorial, capturar o senso de autoeficácia de 544 diretores escolares a partir de um estudo quantitativo realizado em escolas de ensino fundamental e médio da Virgínia (EUA). O instrumento foi composto por uma escala no formato Likert de nove pontos com questões que versavam sobre: (i) a capacidade de gerenciamento, relacionada às demandas diárias do diretor escolar referentes aos procedimentos e tarefas administrativas e a organização de seu trabalho como gestor; (ii) capacidade de gerenciamento de aspectos instrucionais, voltados para aprendizagem e desempenho discente, ou seja, tarefas pedagógica; (iii) e liderança moral, relacionado à capacidade de promover apoio aos docentes e demais funcionários, por meio de estimulação intelectual, articulando e estabelecendo altas expectativas de desempenho (FISHER, 2011; (MCCORMICK, 2001).

Esse trabalho inspirou pesquisas no Brasil, as quais, com a permissão de Tschannen-Moran e Gareis (2004), adaptaram semântica e culturalmente o instrumento para a realidade brasileira. Casanova (2013), por exemplo, adaptou um instrumento composto de dezoito variáveis, com resposta em formato Likert de 10 pontos, pois na adaptação da escala seguiram-se as recomendações apontadas por Bandura (1997; 2006; 2007) que indicaram a necessidade de incluir mais um ponto na escala Likert para mensurar as percepções de autoeficácia. Esse instrumento foi utilizado para investigar as relações explicativas da autoeficácia de gestores a partir de variáveis pessoais, contextuais e as atividades desempenhadas (GUERREIROCASANOVA-RUSSO, 2016; GUERREIRO-CASANOVA \& AZZI, 2012).

Iaochite et al. (2016) afirmam que, metodologicamente, grande parte das pesquisas internacionais e nacionais adotam a abordagem quantitativa de corte transversal, que elegem instrumentos e formas de análise compatíveis com este tipo de estudo. Pesquisas internacionais como a de McCormick et al. (2001), que apresentam uma reflexão sobre a associação entre autoeficácia e liderança, utilizaram análises descritivas - média, desvio-padrão -, correlações e testes de significância para medir e interpretar as variáveis do estudo. 
Em âmbito nacional, Guerreiro-Casanova e Azzi (2012), realizaram um estudo sobre as relações entre a autoeficácia e a eficácia coletiva dos gestores e o índice de vulnerabilidade social (IPVS) da escola em que os diretores atuavam. O estudo envolveu uma análise descritiva (média, desvio-padrão, valor mínimo e máximo) das variáveis, além de uma análise da correlação (teste de Spearman ${ }^{125}$ ), a fim de verificar a relação entre a autoeficácia de gestores escolares, a eficácia coletiva e a vulnerabilidade social - IPVS da escola. As autoras concluem que quanto mais autoeficaz o diretor se percebe, mais ele visualiza o coletivo escolar como eficaz e que há uma relação positiva entre a autoeficácia dos diretores escolares e o IPVS, pois os que se percebiam mais autoeficazes atuavam em contextos com maior vulnerabilidade social e interpretavam essa condição como vantajosa. Isso porque a maior percepção de autoeficácia pode auxiliá-los a liderar com as adversidades que o contexto mais vulnerável pode proporcioná-los.

Guerreiro-Casanova e Russo (2016) estudaram as relações preditivas da autoeficácia dos gestores, considerando os aspectos pessoais, de atividade docente e de contexto. Semelhante ao estudo anterior as análises estatísticas realizadas foram a análise descritiva e a correlação de (Spearman) entre a variável de autoeficácia e variáveis intervalares ${ }^{126}$. Testes de Mann-Whitney (para comparação entre dois grupos ${ }^{127}$ ) e Kruskal-Wallis (para comparação entre três ou mais grupos $^{128}$ ) foram utilizados na análise comparativa, enquanto para as variáveis preditivas de autoeficácia foi realizada a regressão linear univariada e multivariada. Os resultados apresentaram evidência de que as variáveis níveis de ensino, quantidade de alunos por turma, formação, concordância com o Índice de Desenvolvimento da Educação do Estado de São Paulo (IDESP) e satisfação com o trabalho docente estão significativamente associadas à autoeficácia dos gestores escolares, sendo que as duas últimas variáveis formam as maiores contribuições para a construção da autoeficácia dos diretores escolares.

Adotamos, nesta pesquisa, uma análise semelhante à encontrada nos estudos nacionais e internacionais citados acima. Inicialmente, elaboramos um indicador de

\footnotetext{
125 Teste que permite estimar o coeficiente de correlação para variáveis aleatórias x e y relacionadas monotonicamente entre si, mas não necessariamente de maneira linear

${ }^{126}$ Variáveis idade, tempo de exercício, tempo de atuação na escola, duração da jornada de trabalho e número de alunos por turma.

127 Variável Gênero.

${ }^{128}$ Variável nível de ensino da escola (etapas atendidas).
} 
autoeficácia a partir de análise fatorial de três variáveis da questão "Em sua função de diretor, o quanto você consegue:", quais sejam: Planejar e cumprir as atividades de seu trabalho; Resolver os problemas burocráticos inerentes à função; e Apoiar o trabalho pedagógico dos professores. As outras três variáveis (Elevar o desempenho dos alunos no SIMAVE; Usar o SIMADE em aspectos pedagógicos (analisar o desempenho dos alunos); e Usar o SIMADE em aspectos administrativos (organizar horários)) foram desconsideradas porque a primeira não está totalmente inserida no assunto da tese, vez que elevar o desempenho dos alunos no SIMAVE (ou em qualquer avaliação em larga escala) pode estar associado a inúmeros fatores (liderança do diretor, protagonismos docente, etc.), que não necessariamente estão relacionados ao SIMADE e à autoeficácia; as outras duas variáveis também podem não ser associadas à autoeficácia, pois o uso pode ser apenas para atender as exigências da SEE/MG, fazendo com que os respondentes assinalassem como resposta algo que não corresponda à realidade e que poderia equivocadamente indicar a autoeficácia.

As variáveis que compuseram a questão foram inspiradas no instrumento de Guerreiro-Casanova (2014; 2015) e Guerreiro-Casanova e Russo (2016), adaptado do contexto norte americano apresentado por Tschannen-Moran e Gareis, 2004, para a realidade brasileira. Porém, mesmo sabendo que as variáveis e a escala likert já haviam sido testadas e utilizadas em outras pesquisas (GUERREIROCASAVANOVA, 2013; GUERREIRO-CASAVANOVA \& RUSSO, 2016), as adaptamos semanticamente com o intuito de deixá-las mais compreensíveis para o usuário. As duas primeiras variáveis, assim como nos estudos mencionados anteriormente, pertencem à autoeficácia para o gerenciamento e a última para aspectos instrucionais.

Dessa forma, foi possível identificar o padrão de correlação ou de covariância entre as variáveis e gerar um número menor de novas variáveis latentes (não observáveis). Segundo Figueiredo Filho e Silva Júnior, a análise fatorial reduz uma grande quantidade de variáveis observadas a um número reduzido de fatores que representam as dimensões latentes (construtos), que por sua vez resumem ou explicam o conjunto de variáveis observadas (FIGUEIREDO FILHO \& SILVA JÚNIOR, 2010). Assim sintetizamos, através da análise fatorial, as percepções dos 
diretores sobre sua capacidade de realizar as atividades ${ }^{129}$ correspondentes a sua função e uma escala de concordância (nada, muito pouco, médio, muito e completamente).

O resultado do teste Kaiser-Meyer-Olkin (KMO) foi de 0,674, indicando que a análise fatorial é apropriada, na medida em que são considerados como valores aceitáveis entre 0,5 e $1,0^{130}$. Quanto ao coeficiente alfa de Cronbach, temos uma medida de 0,747, indicando também se tratar de um valor aceitável. Tais resultados, portanto, confirmam a seleção das questões para a construção do indicador de autoeficácia do diretor ${ }^{131}$.

Os resultados da estatística descritiva do indicador de autoeficácia usando as três variáveis mencionadas anteriormente encontram-se na tabela a seguir:

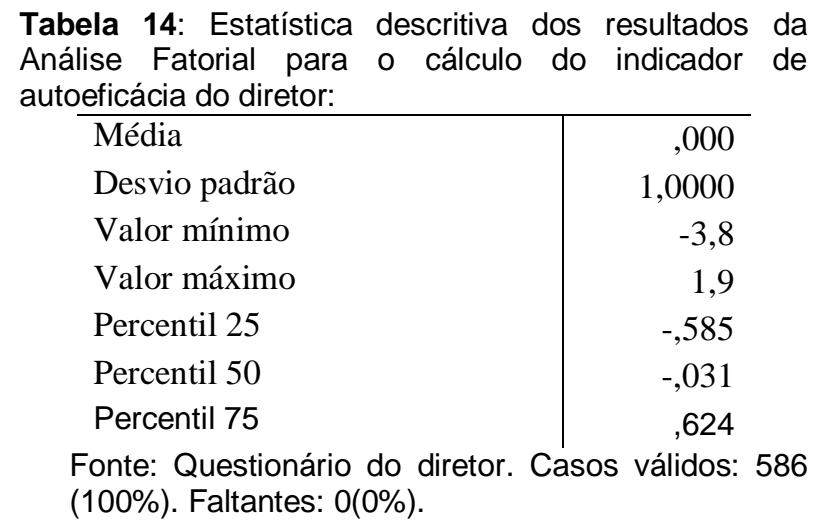

A tabela acima apresenta um grau significativo de variabilidade no índice de autoeficácia do diretor, indicando uma distribuição heterogênea, uma vez que a média é zero e as extremidades se estendem de $-3,8$ até 1,9.

O gráfico a seguir ilustra a distribuição dos valores no índice de autoeficácia:

\footnotetext{
${ }^{129}$ Questão 7 do questionário do diretor: Planejar e cumprir as atividades de seu trabalho; resolver os problemas burocráticos inerentes à sua função; apoiar o trabalho pedagógico dos professores; elevar o desempenho dos alunos no SIMAVE; usar o SIMADE em aspectos pedagógicos (analisar o desempenho dos alunos); usar o SIMADE em aspectos administrativos (organizar horários).

${ }^{130}$ É uma estatística que indica a proporção da variância dos dados que pode ser considerada comum a todas as variáveis, ou seja, que pode ser atribuída a um fator comum, então, quanto mais próximo de 1 (unidade), melhor o resultado, ou seja, mais adequada é a amostra à aplicação da análise fatorial. ${ }^{131}$ Todas as tabelas que apresentam a construção do indicador de autoeficácia e as demais análises deste capítulo estão no anexo 9.
} 
Gráfico 2: Distribuição do indicador de autoeficácia dos diretores.

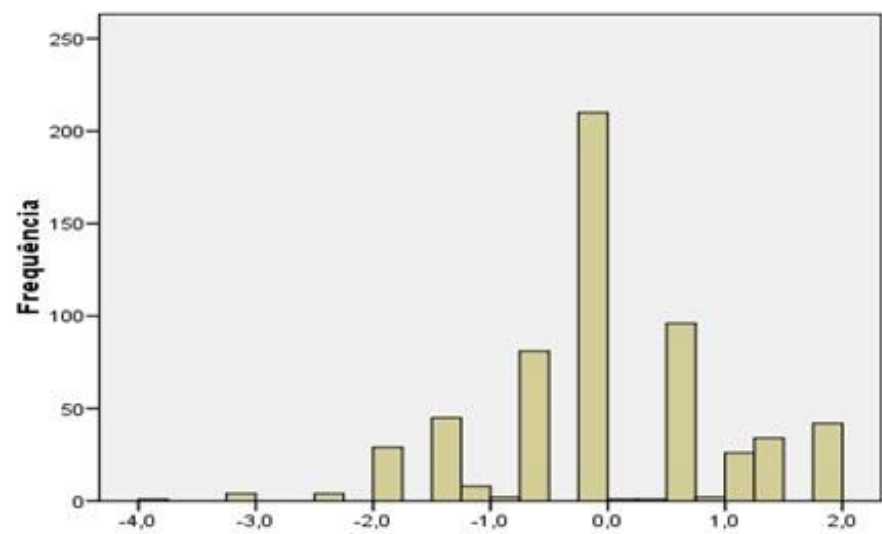

Fonte: Questionário do diretor.

O indicador de autoeficácia, nesta pesquisa, é uma medida avaliativa em que os resultados devem ser comparados uns com os outros e não com um critério externo, como, por exemplo, um ou mais pontos de corte que determinariam certos perfis de gestão escolar. A distribuição dos valores do indicador de autoeficácia está agrupada em três níveis: (i) baixa autoeficácia - valores menores que -1; (ii) autoeficácia adaptativa $^{132}$ - valores entre -1 e 1 ; e alta autoeficácia - valores acima de 1. A opção de se utilizar como pontos de corte os valores de -1 e 1 para o indicador de autoeficácia do diretor se deve a vantagem de produzir grupos mais contrastados do que ocorreria caso tivéssemos utilizado os percentis apresentados na tabela 14 .

A maioria (67\%) dos 586 diretores está no nível de autoeficácia adaptativa, 15,5\% no nível de baixa autoeficácia e 17,4\% no nível de alta autoeficácia. Rodrigues e Barreira (2007), ao analisarem a relação entre autoeficácia e desempenho escolar em alunos do ensino fundamental, apresentam alguns traços de indivíduos que possuem alta autoeficácia: têm percepções mais favoráveis em relação as suas capacidades; antecipam resultados positivos; lidam positivamente com os desafios; e possuem grande persistência para o cumprimento de tarefas (RODRIGUES \& BARREIRA, 2007). Para Iaochite (2017), esses indivíduos acreditam fortemente em suas "capacidades para realizar ações em um dado

\footnotetext{
${ }^{132}$ Este nível foi denominado de adaptativo seguindo a premissa de Bandura (1997) que afirmou que
} níveis intermediários de autoeficácia são, no geral, mais adaptativos. 
domínio, avaliam situações de fracasso como resultado de pouco investimento de esforço pessoal ou das condições adversas do contexto. Isto é, atribuem a causalidade mais a si próprios" (IAOCHITE, 2017, p. 20).

Em contrapartida, os indivíduos que apresentam baixa autoeficácia têm como principais traços: dúvidas sobre suas reais capacidades; não acreditam ser capazes de lidar com situações ameaçadoras, pois se sentem debilitados frente aos esforços necessários; e desistem facilmente de suas tarefas (RODRIGUES \& BARREIRA, 2007). Tais indivíduos se julgam pouco capazes e acabam atribuindo o fracasso ao seu baixo nível de capacidade (IAOCHITE, 2017).

Os indivíduos que têm nível adaptativo de autoeficácia:

não geram a evitação da atividade (como no caso de níveis muito baixos de autoeficácia, em que a pessoa tende a prever o fracasso) nem tampouco um baixo envolvimento com a mesma (quando há percepção de alta autoeficácia), o que também pode gerar um desempenho ruim (LIMA et al., 2016, p. 203).

Iaochite (2017), parafraseando Bandura (1995;1997), faz duas observações que podem esclarecer um pouco mais sobre os níveis de autoeficácia: (i) o sucesso em uma determinada tarefa pode não ocorrer apenas pelo indivíduo acreditar em sua capacidade, pois também é necessário possuir habilidades e conhecimentos necessários para tal ${ }^{133}$; (ii) quanto maior for a expectativa de que um determinado comportamento trará resultados - e sendo esse extremamente valorizado pelo indivíduo - maior será a motivação em tentar realizar esse comportamento. $\mathrm{O}$ autor conclui afirmando que a autoeficácia "determina as metas que as pessoas escolhem para si próprias, o quanto de esforço elas despenderão para realizá-las, o quanto serão perseverantes diante dos desafios e o quanto serão resilientes diante dos fracassos" (IAOCHITE, 2017, p. 17).

Buscando verificar se esses níveis de autoeficácia se associavam a características dos diretores e das escolas, selecionamos as variáveis idade do diretor e desempenho discente, já amplamente analisadas em pesquisas sobre autoeficácia (GUERREIRO-CASANOVA \& RUSSO, 2016) e variáveis referentes às fontes de informação utilizadas dentro das escolas e às atribuições diárias dos diretores para buscar possíveis associações.

133 Podemos citar como exemplo um diretor que no início de seu primeiro mandato julga não estar capacitado para exercer sua função e, ao iniciar a gestão, infere que não tem habilidade ou conhecimento para lidar com os desafios da gestão. Diante disso, ele visualizará a si próprio tendo muitos problemas. 


\subsection{Possíveis associações entre o indicador de autoeficácia, a idade do diretor, o desempenho da escola, as fontes de informação e as tarefas da direção da unidade de ensino}

Neste item analisamos características do diretor, da escola em que atua e aspectos de sua rotina de trabalho com o intuito de compreender se havia alguma associação significativa entre elas e o indicador de autoeficácia. Para tal, utilizamos o teste de variância ou ANOVA, que é um teste paramétrico - que possui estimativas de parâmetros -, utilizado quando se deseja verificar se existem diferenças entre as médias de uma determinada variável (variável resposta) em relação a um tratamento com dois ou mais níveis categóricos (variável preditora). Nesta pesquisa, a ANOVA será utilizada para comparar idade, resultados escolares, fontes de informação e atividades diárias realizadas pelo diretor e o indicador de autoeficácia, buscando avaliar se existem diferenças consideráveis entre os grupos investigados em relação a essas variáveis ${ }^{134}$.

Inicialmente testamos a possível associação entre o indicador de autoeficácia e a idade do diretor (em três faixas: até 40 anos, de 41 a 55 anos, 56 anos ou mais). O teste de variância indicou que a variação não é estatisticamente significativa, ou seja, o nível de autoeficácia do diretor não é afetado pela idade de forma estatisticamente relevante nesta amostra. Portanto, os diretores tendem a ter opiniões sobre a sua autoeficácia de modo mais ou menos homogêneo independente da variação da idade.

Esse resultado é semelhante ao observado por Guerreiro-Casanova e Russo (2016), em que não se encontraram relações significativas entre a autoeficácia dos gestores escolares e a idade. Cabe observar, porém, que mesmo não tendo sido encontradas diferenças estatisticamente significativas, os diretores com faixa etária até 40 anos e acima de 56 anos (os dois extremos) apesentaram autoeficácia mais elevada do que aqueles que possuem idade entre 41 e 55 anos, como se observa no gráfico a seguir.

${ }^{134}$ Todas as tabelas e gráficos do item Possíveis associações entre o indicador de autoeficácia, a idade do diretor, o desempenho da escola, as fontes de informação da escola e as tarefas da direção da unidade de ensino estão no anexo 9 
Gráfico 3: Indicador de autoeficácia e faixa etária dos diretores.

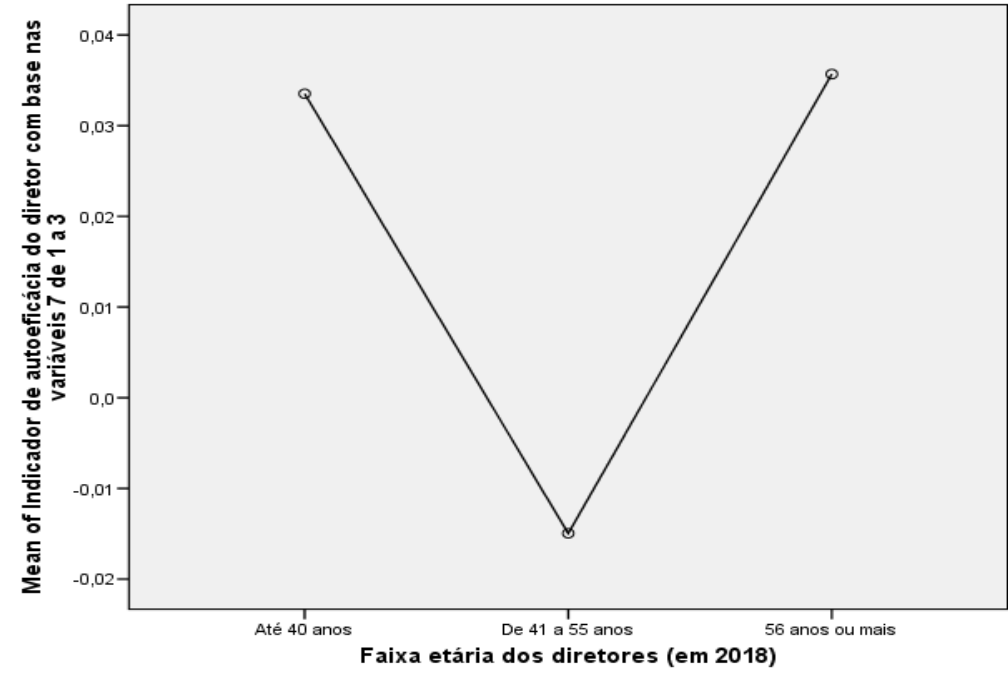

Fonte: Questionário do diretor.

Como, segundo Iaochite (2017) e Iaochite et al. (2016) a autoeficácia se constitui pela interpretação e avaliação (processamento cognitivo e pensamento reflexivo) das informações advindas de quatro fontes de informação, podemos levantar a hipótese de que os resultados encontrados para os dois extremos da distribuição etária dos diretores (os mais jovens e os mais experientes) possam ser compreendidos em função de sua trajetória profissional. Nessa perspectiva, supõese que o percurso pessoal e profissional, como mencionado no item $2.3 \mathrm{~A}$ elaboração dos questionários das escolas estaduais de Minas Gerais: aprofundando o referencial teórico, poderia comportar mais experiências diretas (realização de tarefas semelhantes ou que se repetem na direção escolar); experiências vicárias (observação de outros diretores ou de sua forma de gestão); persuasão social (expressa nas formas de orientação, avaliação, opinião, elogios e críticas sobre sua atuação); e o equilíbrio dos estados fisiológicos e afetivos (exemplo: medo, ansiedade, alteração de frequência cardíaca, que ocorrem na preparação ou realização de uma tarefa) que lhes auxiliaram a criar um senso mais forte sobre autoeficácia.

Em seguida analisamos a correlação entre o nível de autoeficácia dos diretores e os resultados escolares. $\mathrm{O}$ indicador de desempenho bruto das escolas da amostra foi calculado a partir dos resultados de Matemática dos $5^{\circ}$ e $9^{\circ}$ anos do Ensino Fundamental referentes a dois anos consecutivos de avaliação externa: a 
Prova Brasil em 2015 e o SIMAVE em 2016. A utilização de uma série temporal (dois anos ou mais) fornece mais subsídios acerca da qualidade da escola, pois quando se calcula os resultados médios, os extremos que podem aparecer (causados por flutuações aleatórias na amostra) tendem a se cancelar, fazendo com que o valor médio obtido se aproxime mais do valor real.

Cabe mencionar que todas essas quatro provas tiveram seus resultados originalmente expressos numa mesma escala: a de proficiência de Matemática nacionalmente utilizada pelo SAEB. Isso foi obtido no próprio processo de construção desses testes, por meio da inserção, em sua composição, de itens questões - comuns a dois ou mais desses testes, cujos parâmetros, mantidos constantes, possibilitaram a equalização entre as diferentes provas. Dessa forma, um meio natural de se obter o indicador médio de desempenho de cada escola seria calcular a sua média a partir de todos esses resultados.

Foi então realizada uma padronização das quatro distribuições de médias escolares de matemática: $5^{\circ}$ e $9^{\circ}$ anos do Ensino Fundamental na Prova Brasil de 2015 e também no SIMAVE de 2016. Cada uma dessas quatro medidas passou a ser expressa segundo uma distribuição aproximadamente normal e padronizada, de média 0 e desvio-padrão 1 . A partir daí, calculou-se a média das quatro medidas e se chegou ao indicador geral de desempenho de cada escola da amostra ${ }^{135}$.

Ao mesmo tempo, ao se elaborar o indicador de desempenho bruto, também houve um interesse em verificar o desempenho relativo das escolas, ou seja, ver como umas estavam se comportando em relação às outras. Porém, para evitar problemas relacionados ao fato de que nem todas as escolas fizeram os mesmos testes, vez que algumas participaram das avaliações em larga escala apenas com os alunos do $5^{\circ}$ ano ou do $9^{\circ}$ ano, pois só oferecem ensino nos anos iniciais ou finais do Ensino Fundamental, foi realizada uma padronização das quatro distribuições de médias escolares de matemática. Cada uma dessas quatro medidas passou a ser expressa segundo uma distribuição aproximadamente normal e padronizada, de

135 No caso específico das escolas que só apresentaram resultados para um dos anos do Ensino Fundamental $\left(5^{\circ}\right.$ ou $\left.9^{\circ}\right)$, ou para apenas uma das edições do teste (2015 ou 2016), houve, naturalmente, menos dados para o cálculo da média. Porém, o possível desequilíbrio decorrente dessa falta de dados, cobrindo diferentes regiões da escala de proficiência, foi evitado com o procedimento de padronização acima mencionado 
média 0 e desvio-padrão 1. Em seguida, calculou-se então a média dessas quatro medidas, para se chegar ao indicador geral de desempenho ${ }^{136}$.

A seguir, apresentamos um histograma da distribuição da média geral de Matemática:

Gráfico 4: Média dos quatro escores em matemática (média geral de Matemática)

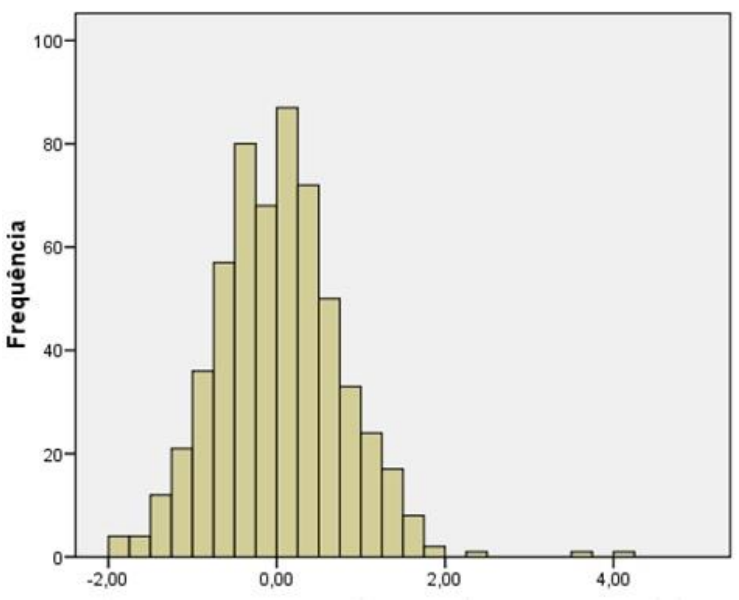

Média $=0,02$

$\mathrm{DP}=0,74$

Fonte: Prova Brasil 2015 e SIMAVE 2016

Com esses resultados realizou-se uma regressão linear clássica ${ }^{137}$. De modo semelhante ao resultado com a idade, os resultados não se mostraram significativos. O nível de autoeficácia do diretor explica menos de $1 \%$ da variação da média do desempenho em matemática das escolas da amostra, o que não é estatisticamente significativo $^{138}$.

Em seguida verificamos se os 586 diretores consideravam o SIMADE, SIMAVE, IDEB, avaliações externas, site e dados da escola fontes de informação e se havia alguma diferença em relação ao uso dessas informações por diretores com distintos níveis de autoeficácia. Para tanto, analisamos a questão fechada " $E m$ seu cotidiano, quais são as fontes de informação que você utiliza para buscar dados sobre a escola? Em que os diretores podiam selecionar uma ou mais respostas de uma lista definida de opções ${ }^{139}$. Essas variáveis (alternativas de respostas) foram

\footnotetext{
${ }^{136} \mathrm{O}$ anexo 10 tem a descrição detalhada da construção do indicador geral de desempenho,

${ }^{137}$ Uma regressão linear simples analisa a relação entre uma variável dependente e outras variáveis independentes. A relação entre elas é representada por um modelo matemático, que associa a variável dependente às variáveis independentes.

${ }^{138}$ Uma das possibilidades de explicação seria o fato da influência da autoeficácia do diretor ser uma característica demasiado indireta no que toca ao desempenho dos alunos, portanto difícil de medir, particularmente considerando os limites da amostra, bem como da ferramenta de pesquisa, e da disponibilidade de informações sobre o desempenho acadêmico das escolas. De qualquer forma, certamente esta questão merecerá no futuro novos estudos.

${ }^{139}$ SIMAVE (resultado do PROALFA e/ou PROEB); Censo Escolar (Educacenso); SIMADE; INEP (Plataforma Devolutivas Pedagógicas, resultados do SAEB e/ou Prova Brasil); Índice de
} 
organizadas em quatro grupos, com novas variáveis, construídas de acordo com o órgão oficial responsável pela fonte de informação: (i) MG: o(a) diretor(a) usa SIMAVE e/ou SIMADE; (ii) MEC: o(a) diretor(a) usa Censo, plataformas do INEP, IDEB; (ii) Sites: o(a) diretor(a) usa Qedu, Todos Pela Educação, etc.; e Escola: o(a) diretor(a) usa dados da própria escola. A seguir a tabela 15 apresenta a estatística descritiva das quatro variáveis:

Tabela 15: Fontes de informação usadas pelo Diretor.

\begin{tabular}{|c|c|c|c|c|c|c|}
\hline \multirow{2}{*}{ Fonte de Informação } & \multicolumn{2}{|c|}{ Sim } & \multicolumn{2}{|c|}{ Não } & \multicolumn{2}{|c|}{ Total } \\
\hline & $\mathbf{N}$ & $\%$ & $\mathbf{N}$ & $\%$ & $\mathbf{N}$ & $\%$ \\
\hline $\begin{array}{l}\text { Estado de Minas Gerais (SIMADE e } \\
\text { SIMAVE) }\end{array}$ & 574 & 98,0 & 12 & 2,0 & 586 & 100,0 \\
\hline $\begin{array}{l}\text { Ministério da Educação (Educacenso e/ou } \\
\text { plataformas do INEP e/ou IDEB }\end{array}$ & 527 & 89,9 & 59 & 10,1 & 586 & 100,0 \\
\hline Sites (Todos pela Educação, QEdu, etc.) & 114 & 19,5 & 472 & 80,5 & 586 & 100,0 \\
\hline Escola (diários, etc.) & 476 & 81,2 & 110 & 18,8 & 586 & 100,0 \\
\hline
\end{tabular}

Observa-se que as fontes de informação mais utilizadas nas 586 escolas da amostra são o SIMAVE e o SIMADE, fontes essas produzidas pela SEE/MG, seguidas pelas fontes do MEC e as da própria escola. Os sites são as fontes de informação menos utilizadas. Esse resultado é semelhante ao observado por Parra e Malta (2016), pois os dados que têm maior relevância para as escolas são aqueles gerados em seu interior, que permitem (res)significar, de forma contextualizada, as práticas adotadas pela instituição de ensino, configurando-se como uma ferramenta importante para a melhora dos processos de gestão. Fica a hipótese de que o SIMAVE e o SIMADE sejam as principais fontes por oferecerem, respectivamente, informações detalhadas sobre o desempenho dos discentes em Língua Portuguesa e Matemática anualmente na(s) avaliação(ões) em larga escala estadual; e por disponibilizar informações, em tempo real, que abrangem o rendimento discente, aprendizagem dos alunos, a organização curricular da escola e os dados de funcionários.

Entretanto, todas as fontes de informação podem agregar valor às práticas de gestão. SIMADE e SIMAVE podem, por um lado, auxiliar na eficiência para a realização das tarefas, já que tais ferramentas fornecem evidências necessárias para melhorar a parte pedagógica (processo de ensino aprendizagem, rever a 
metodologia de ensino, etc.) e administrativa (agilidade nos procedimentos básicos da escola, como por exemplo matrícula, lançamento de notas e frequência, etc.), que contribuem para a tomada de decisões (BALDUTI, 2017; CALDERÓN, 2017). Por outro lado, podem reforçar as estratégias de controle exercidas pela SEE/MG ao definir quais as informações são mais importantes de serem acatadas pelos diretores para melhorar o desempenho discente, com intuito de buscar o cumprimento das metas educacionais em relação ao SIMAVE e o melhor rendimento escolar a partir dos dados do SIMADE.

No entanto, esse resultado vai de encontro às inúmeras pesquisas (BROOKE \& CUNHA, 2011; CALDERÓN, 2017; CERDEIRA et al., 2017; BAUER et al, 2015; SILVA et. al., 2013) que observaram que os agentes escolares têm dificuldade em compreender os dados das avaliações em larga escala e, consequentemente, não os utilizam em seu cotidiano e não tomam decisões fundamentadas em evidências fornecidas por esses dados. Diante disso, aventamos a hipótese de que o resultado em relação ao uso das fontes de informação tenha sido potencializado devido ao uso do SIMADE e também pela disponibilização anual dos resultados do SIMAVE, ou seja, pelas ferramentas disponibilizadas pela SEE/MG.

As fontes de informação oriundas do MEC (IDEB, Censo Escolar (Educacenso), e INEP (Plataforma Devolutivas Pedagógicas, resultados do SAEB e/ou Prova Brasil) agrupam dados encontrados em outros instrumentos de gestão ou que estão dispersos dentro da escola. Contribuem para o desenvolvimento de ações e políticas públicas no sistema de ensino (CERDEIRA et al, 2017; FONTANIVE, 2013), ao mesmo tempo que possibilitam que a gestão tenha acesso a informações de uma forma sintetizada, como, por exemplo, em índices ${ }^{140}$, indicadores ${ }^{141}$, e $\operatorname{taxas}^{142}$ das escolas e do sistema de ensino, oportunizando um aprimoramento dos processo de trabalho visando a melhor condução das atividades e a criação de novos conhecimentos que gerem ações dentro da unidade de ensino (ARAÚJO, 2014; MASSA et al., 2018; PONTES, 2015). Todavia, o caráter bianual

\footnotetext{
140 "São medidas que numericamente combinam, ou sintetizam, as informações contidas em dois ou mais indicadores relevantes para um dado objeto de estudo" (PONTES, 2012, p.68).

141 "São medidas específicas que têm por objetivo transmitir uma informação referente a uma dimensão particular e relevante da educação, expressando-se através de números que sintetizam essa dimensão" (PONTES, 2012, p. 67).

142 Taxas são a proporção de (algo) em um conjunto, geralmente expresso em porcentagem.
} 
da divulgação dos resultados das avaliações em larga escala, e anual em relação ao Censo Escolar, conforme já mencionado no primeiro capítulo, remete o diretor a uma realidade que não mais diz respeito à atual configuração do contexto escolar, o que explicaria seu uso menos difundido do que o SIMADE.

Cabe ressaltar que mesmo com a divulgação anual dos resultados do SIMAVE, dos instrumentos do MEC (Censo Escolar) e bianual (IDEB, e INEP (Plataforma Devolutivas Pedagógicas, resultados do SAEB e/ou Prova Brasil) e os dados em tempo real do SIMADE, os materiais da própria escola ainda são uma fonte de informação primária, pois “(...)contêm informações originais ou, pelo menos, novas interpretações de fatos ou ideias já conhecidas (GOMES \& DUMONT, 2015, p. 135)", que ainda tem relevância dentro da unidade de ensino vez que mais de $80 \%$ dos diretores assinalaram essa fonte de informação dentre as que eles mais usam.

Quanto ao uso das fontes de informação de Sites, apesar de compilarem as informações de diferentes fontes oficiais (IDEB, Censo Escolar, etc), seu caráter mais informal pode estar refletindo em seu uso pelos diretores escolares da amostra desta pesquisa. No entanto, esse tipo de fonte exige que o diretor esteja mais informado para tomar conhecimento desses sites e consultá-los, além de ter uma postura mais engajada, no sentido de se manter informado sobre os resultados de sua escola.

De forma análoga ao encontrado nas fontes de informações de MG, do MEC (IDEB, Censo Escolar (Educacenso), e INEP (Plataforma Devolutivas Pedagógicas, resultados do SAEB e/ou Prova Brasil), sites (QEdu e Todos pela Educação) e materiais impressos, os resultados da Anova não foram estatisticamente significativos em relação a essas fontes e o indicador de autoeficácia $^{143}$. Portanto, não há diferença de uso dessas fontes de informação por diretores em distintos níveis de autoeficácia.

Por último, examinamos a possível relação entre a autoeficácia do diretor e a frequência com que ele realiza algumas atividades na escola que expressam em certa medida as ênfases do trabalho da gestão na rotina organizacional. Segundo Datnow e Schildkamp (2019) uma rotina organizacional pode definir-se "como um conjunto de ações interdependentes e recorrentes que envolvem múltiplos atores e

\footnotetext{
${ }^{143}$ Para visualizar as tabelas da ANOVA para cada uma das fontes de informação consulte o anexo
} 9 
que estruturam as práticas cotidianas das escolas, respaldando e focalizando as interações entre os membros da equipe escolar" (DATNOW \& SCHILDKAMP, 2019, p. 80). Para tal, usamos análise de variância para as onze variáveis da questão "Indique com que frequência você realiza as seguintes atividades no seu trabalho na direção escolar ${ }^{144}$ ", expressa por uma escala de Likert (nunca, raramente, algumas vezes e frequentemente).

Cada variável foi considerada como dependente e o indicador de autoeficácia como a variável independente. Observamos que houve uma diferença considerável e estatisticamente significativa entre os níveis de autoeficácia e algumas das variáveis ${ }^{145}$, conforme apresentada na tabela a seguir:

Tabela 16: Indique com que frequência você realiza as seguintes atividades no seu trabalho na direção escolar

\begin{tabular}{lccc}
\multicolumn{1}{c}{ Variáveis } & \multicolumn{3}{c}{ Níveis do indicador de autoeficácia do diretor } \\
\hline Acompanhar a entrada e saída dos alunos & Baixa & Adaptativa & Alta \\
Atender aos pais & $\mathrm{x}$ & $\mathrm{x}$ & $\mathrm{x}$ \\
Assistir às aulas (ou parte delas) & $\mathrm{x}$ & $\mathrm{x}$ & $\mathrm{x}$ \\
$\begin{array}{l}\text { Elaborar relatórios e mapas de notas } \\
\text { Orientar o planejamento escolar (conteúdos a }\end{array}$ & $\mathrm{x}$ & $\mathrm{x}$ & $\mathrm{x}$ \\
priorizar, estratégias de ensino e formas de & & & $\mathrm{x}$ \\
avaliação) & & & \\
Fonte: Questionário do diretor.
\end{tabular}

Esses resultados colocam em evidência que os diretores do nível baixa autoeficácia realizam atividades que exigem sua presença física na escola com foco nas interações e nos relacionamentos estabelecidos com os discentes e pais. Fica a hipótese de que tais atividades possam estar relacionadas, assim como observado em estudo de Polon e Bonamino (2011) e Polon (2012) a um "estilo de gestão" (PAES DE CARVALHO \& CANEDO, 2012) mais relacional, ou seja, "as tarefas associadas à sua presença no cotidiano escolar e que privilegiem o atendimento aos alunos e pais" (POLON \& BONAMINO, 2011, p. 9).

Os diretores do nível adaptativo de autoeficácia realizam as atividades que remetem a sua presença no cotidiano, mas que também se voltam para atividades

\footnotetext{
${ }^{144}$ Acompanhar a entrada e saída dos alunos; atender aos pedidos dos professores (equipamentos e materiais); assistir às aulas (ou parte delas); elaborar relatórios ou mapas de notas; orientar o planejamento escolar (conteúdos a priorizar, estratégias de ensino e formas de avaliação); conversar com os professores sobre o desempenho de seus alunos nas avaliações; atender aos pais; organizar festas e eventos da escola; dar aulas quando algum professor falta; acompanhar reuniões e/ou conversas entre o supervisor e o professor sobre alunos; acompanhar os passeios pedagógicos.

145 As tabelas estão no anexo 9.
} 
que visam o monitoramento do processo de ensino aprendizagem, resultados dos discentes e o planejamento escolar. Ou seja, esses diretores possuem um "estilo de gestão" que têm nuances relacionais, mas sua ênfase são as tarefas que denotam, respectivamente, "estilo de gestão" organizacional (Elaborar relatórios e mapas de notas), que pode - indiretamente - se reverter em "suporte ao trabalho do professor em suas necessidades cotidianas, ou controlar resultados através da produção de mapas, planilhas" (POLON \& BONAMINO, 2011, p. 9) e um "estilo de gestão" também focado nos aspectos pedagógicos.

Esses diretores, assim como os de nível alta autoeficácia, ao realizarem tais tarefas (Assistir às aulas (ou parte delas) e Orientar o planejamento escolar (conteúdos a priorizar, estratégias de ensino e formas de avaliação), exerceriam assim, na concepção de Polon e Bonamino (2011) e Polon (2012), "estilo de gestão" que "expressam especial atenção à atividade de orientação e acompanhamento do planejamento escolar" (POLON \& BONAMINO, 2011, p. 9). Portanto, podemos constatar que quanto maior a autoeficácia mais os diretores se dedicam a tarefas de monitoramento do processo de ensino aprendizagem, do rendimento discente, bem como do planejamento com intuito de propor ações que podem melhorar o desempenho dos estudantes.

Esse resultado corrobora a afirmação de Bandura (1986) de que a autoeficácia é uma importante variável preditiva do desempenho de tarefas. Somase a isso o fato de os três atributos da autoeficácia, segundo Bandura (1986): (i) a magnitude, "associada ao nível de dificuldade de tarefas específicas que as pessoas acreditam que podem realizar" (GUIMARÃES \& ABBAD, 2015, p. 173); (ii) a força, "ou nível de confiança (ou convicção), apresentado pelo indivíduo sobre as próprias capacidades de executar determinadas tarefas" (GUIMARÃES \& ABBAD, 2015, p. 173); (iii) a generalização, “a expectativa que o indivíduo possui de poder generalizar suas capacidades, aplicando-as com êxito em situações similares" (GUIMARÃES \& ABBAD, 2015, p. 173); também poderem estar influenciando na percepção dos diretores sobre a sua autoeficácia para realizar as tarefas do cotidiano.

No próximo tópico, vamos analisar o SIMADE, especificamente quanto à sua utilização pelos diretores nos aspectos administrativos e pedagógicos da gestão, em relação à autoeficácia dos diretores. 


\subsection{A autoeficácia e o SIMADE: o uso dos dados na gestão da escola}

Buscando compreender se e de que forma os diretores de escolas usam o SIMADE, o questionário de diretor incluiu também questões abertas - "Em seu cotidiano, você utiliza o SIMADE? Se sim, como?" possibilitando um espaço de expressão menos guiada do respondente sobre o tema. As respostas a esssa questão foram analisadas com o auxílio da metodologia de análise de conteúdo que, segundo Carlomagno e Rocha (2016, p. 175) "se destina a classificar e categorizar qualquer tipo de conteúdo, reduzindo suas características a elementos-chave, de modo com que sejam comparáveis a uma série de outros elementos”.

Dos 586 diretores, 137 responderam apenas a primeira parte da pergunta (46 Não e $91 \mathrm{Sim}$ ), fazendo com que suas respostas fossem desconsideradas por não usarem o SIMADE ou por não explicitarem a forma de uso do sistema. Outros 50 diretores não responderam à questão. As 399 escolas restantes foram agrupadas em categorias, mutuamente excludentes, com o intuito de captar o uso pelos diretores, uma vez que suas atribuições diárias podem estar refletindo o uso do sistema.

Segundo Carlomagno e Rocha (2016, p. 178), a definição das categorias ocorre a partir de regras que especificam os sinais que devem ser classificados em cada uma delas. As referências para a definição das categorias foram as atribuições diárias do diretor já apresentadas pela literatura em gestão escolar (LEAL \& NOVAES, 2018; WERLE \& AUDINO, 2015; FORMIGA \& BARBOSA, 2007), descritas no capítulo 2 e as normas legais da rede pública estadual de Minas Gerais, que definem a atuação dos diretores escolares (Resolução SEE n 03/2015; Resolução SEE nº 1.812 de 15/04/2011) e o uso do SIMADE ( Resolução SEE n ${ }^{a}$ $1.180 / 2008)$.

Inicialmente, agrupamos as 399 escolas em cinco categorias: (i) aluno respostas voltadas para a vida escolar dos alunos (notas, frequência, aprovação, reprovação); (ii) técnica - respostas que remetiam as funcionalidades do sistema; (iii) aspectos gerais - respostas que mencionavam o uso do sistema; (iv) planejamento - respostas que remetiam ao uso do sistema para planejar ações e estratégias para melhorar o rendimento e desempenho da escola; e (v) enturmação - respostas que associavam o uso dos dados do sistema para definir a enturamção 
dos discentes. No entanto, percebemos que as categorias alunos, planejamento e enturmação remetiam, basicamente, aos aspectos pedagógicos, ao passo que as categorias técnica e aspectos gerais estavam voltadas para questões administrativas.

Tendo em vista as duas categorias encontradas, e também as considerações das pesquisas sobre gestão escolar, as normas legais da rede pública estadual de Minas Gerais e a necessidade de caracterizar o uso do sistema, foram adotadas duas categorias:

- Respostas administrativas - diretores que utilizam o sistema considerando apenas o previsto na resolução que regulamenta o SIMADE, ou seja, inserir e atualizar as informações no sistema. O uso parece ocorrer apenas para atender à legislação vigente (cumprir prazos e informar as instâncias superiores sobre o que ocorre na escola). Exemplos: respostas que mencionavam a necessidade, vantagem ou relevância de agilizar o trabalho da secretaria da escola; o lançamento de notas e frequência; a coleta de dados; a emissão de relatórios e declarações; menção à obtenção de informações em geral; menção à rapidez para fornecer documentos; menção à otimização do acesso aos dados e informações. Esse grupo é composto de 261 diretores.

- Respostas pedagógicas - diretores que usam o sistema considerando o previsto na legislação sem perder de vista as especificidades de rendimento e desempenho discente. $\mathrm{O}$ uso parece contemplar a possibilidade de maior autonomia do diretor para intervir no funcionamento e nos resultados da escola. Exemplos: menção aos alunos (acompanhamento do rendimento, verificação da vida do aluno, histórico dos alunos, situações de progressão parcial (dependência), etc.); além de respostas que indicam desempenho, planejamento ou atividades e ações com a finalidade de planejar (diagnóstico, melhoria, resultado, estratégia, aprendizagem e pedagógico) e melhoria nos resultados das avaliações externas e da aprendizagem discente. Esse grupo é composto de 138 diretores.

$\mathrm{Na}$ primeira categoria, a legislação parece ser o fator determinante do uso do SIMADE, indicando uma utilização preocupada com o cumprimento de uma norma e com o controle da unidade escolar. Cabe ressaltar que a permanente 
atualização dos dados do sistema (que, como já discutido, é em boa medida também do interesse da escola, pois lhe garante recursos para o funcionamento), viabiliza fácil acesso para atender não só a escola, como também as SREs e a SEE/MG, e assim contribui para uma execução dos serviços escolares de forma mais padronizada. Particularmente, este tipo de uso propõe uma nova forma de regulamentação - centrada na definição e controle a priori dos procedimentos (BARROSO, 2005) -, vez que as regras do uso estão codificadas em regulamentos, que acabam por ter um valor em si mesmas, independentemente do uso. O intuito é assegurar a coerência, o equilíbrio e a reprodução idêntica do uso do sistema por todas as escolas, por meio de práticas que permitam o controle e o registro do que ocorre nas unidades de ensino.

Já na segunda categoria, pode-se considerar que o aluno parece ser o foco e que o uso do SIMADE facilitaria o monitoramento do desempenho do aluno. Há uma vasta literatura que aponta fatores bastante aceitos como associados à eficácia escolar, sendo um deles o monitoramento do progresso, cuja ênfase é no monitoramento do desempenho dos alunos e na avaliação do desempenho da escola (SAMMONS, 2008; BONAMINO, 2012). O monitoramento é característica importante, pois monitorar o desempenho discente e da escola pode assegurar informações que permitam diagnósticar e propor estratégias para melhoar a qualidade do ensino. Considerando o caráter mais genérico da resolução do SIMADE, o fato desses profissionais expressarem a preocupação com o desempenho do aluno vinculada ao uso do sistema, parece indicar que há valorização de uma gestão pedagógica da escola lastreada em dados fornecidos pelo sistema.

No aspecto pedagógico o termo eficiência, aplicado aos sistemas de ensino, está relacionado à ordem de recursos e custos, significando alcançar os resultados pretendidos com os menores custos possíveis (AUGUSTO, 2010), enquanto a eficácia denota o grau em que a unidade de ensino cumpre suas funções mediante a satisfação dos objetivos e metas fixados (BROOKE, 2010). A utilização do sistema, portanto, se volta para a otimização da função da escola enquanto espaço por excelência de ensino-aprendizagem, uma vez que o SIMADE é compreendido como um recurso para desenvolver o trabalho pedagógico, que gera pouco custo para a escola. 
Esse resultado corrobora a afirmação de Lotta (2014), pois a diversidade de contexto de implementação pode fazer com que uma mesma regulamentação produza resultados inteiramente diversos em realidades diferentes. Ou seja, o contexto da escola pode estar impactando pelo tipo de uso do sistema, embora as ações, valores e referências dos diretores também influenciem e transformem o modo como a política foi concebida.

Parte dessa diferença é explicada pela própria legislação, que não explicita o que se "espera" dos usuários do SIMADE em relação ao uso dos de seus dados. Explica-se também pela interpretação e adaptação da política realizada pelos diretores, que lhes permite construir um contexto específico para sua atuação no uso dos dados do sistema podendo, por sua vez, ampliar o exercício da discricionariedade.

A discricionariedade que os diretores empregam no uso do sistema pode elevar o comprometimento dos diretores com os resultados educacionais, melhorando as condições de ensino e estimulando o acompanhamento da aprendizagem dos alunos, caso o SIMADE seja utilizado para o pedagógico. Há, portanto, uma preocupação com os fins, as metas a atingir.

O resultado da divisão das respostas indicou que 261 diretores estão na categoria Administrativo e 138 na categoria Pedagógico no que se refere ao uso do SIMADE. Esse resultado corrobora o que já havia sido constatado por Soares el al. (2017), que afirmam ser comum, na prática da gestão escolar, os diretores se dedicarem mais à gestão administrativa do que à pedagógica, e também o já constatado nesta pesquisa, a qual conclui que os diretores dedicam mais do seu tempo à gestão adminsitrativa.

Embora o administrativo e o pedagógico sejam dimensões que não podem ser colocadas em posições antagônicas, os resultados encontrados podem ser compreendidos a partir de duas hipóteses: (i) a SEE/MG e as SREs exigem das escolas um uso muito mais administrativo do que pedagógico do sistema, já que as demandas que poderiam ser pedagógicas são tratadas como meramente informativas (quantitativo de alunos aprovados, reprovados, em progressão parcial, projetos extraturnos, etc.); (ii) como o diretor não é o principal usuário do sistema e parece não participar de muitos cursos sobre o SIMADE, conforme mencionado nas características dos sujeitos - item 3.1.2 características dos sujeitos, ele pode ter dificulade em usar o sistema de forma pedagógica, ou seja, usando os dados para 
traçar um diagnóstico da escola com informações úteis para a definição de estratégias de ação capazes de responder adequadamente aos problemas ou desafios identificados.

Observamos também que, em algumas escolas (133 das 399), as respostas de diretores, secretários e ATBs eram compatíveis, ou seja, os dois indicavam um uso mais administrativo ou pedagógico do sistema. Em 70 escolas tanto diretores como secretários indicaram um uso administrativo do sistema, enquanto em 63, uns e outros indicaram usos considerados pedagógicos. Pode-se levantar a hipótese de que nesses casos haveria um considerável alinhamento entre diretores, secretários e ATBs, que partilhariam percepções similares sobre os usos do sistema, possivelmente numa relação produtiva de colaboração, que pode repercutir favoravelmente no clima escolar.

Nas análises das questões "O SIMADE influencia na organização da escola? Se sim, como?" e "O SIMADE influencia na parte pedagógica da escola? Se sim, como? também consideramos o mesmo universo de 399 escolas, porém em cada questão, respectivamente, $50^{146}$ e $67^{147}$ diretores reponderam apenas Sim ou Não. Novamente constatamos, a partir dos mesmos critérios de análise das categorias, que a maioria dos diretores usam o SIMADE para a parte administrativa - 270 respostas foram classificadas nesta categoria na primeira questão e 190 na segunda questão.

Com base na análise dessas respostas abertas às três perguntas e também nos achados da literatura de referência (LEAL \& NOVAES, 2018; WERLE \& AUDINO, 2015; FORMIGA \& BARBOSA, 2007; GUERREIRO-CASANOVA \& RUSSO, 2016; GUERREIRO-CASANOVA \& AZZI, 2012; BALDUTI, 2017), podemos afirmar que existem dois tipos de uso do SIMADE: (i) o uso administrativo; (ii) o uso pedagógico. A tabela a seguir apresenta a distribuição desses tipos de uso por nível de autoeficácia dos diretores:

Tabela 17: Distribuição das categorias administrativa e pedagógica por autoeficácia.

\begin{tabular}{lcccccc}
\hline Tipos de uso do SIMADE & \multicolumn{2}{c}{ Níveis do indicador de autoeficácia do diretor } \\
& & Baixa & \multicolumn{2}{c}{ Adaptativa } & \multicolumn{2}{c}{ Alta } \\
\hline \multirow{3}{*}{ Administrativo } & $\mathrm{N}$ & $\%$ & $\mathrm{~N}$ & $\%$ & $\mathrm{~N}$ & $\%$ \\
Pedagógico & 31 & $60,7 \%$ & 180 & $64,5 \%$ & 50 & $72,5 \%$ \\
Total & 20 & $39,3 \%$ & 99 & $35,5 \%$ & 19 & $27,5 \%$ \\
\hline
\end{tabular}

Fonte: Questionário do diretor

14610 escolas responderam apenas Não e 40 escolas responderam apenas Sim.

14741 escolas responderam apenas Não e 26 escolas responderam apenas Sim. 
Constata-se que, em todos os níveis de autoeficácia, predomina o tipo de uso do SIMADE voltado para o aspecto administrativo, sendo que, no nível de alta autoeficácia, o quantitativo é mais que o dobro do número de escolas que usam o sistema voltado para o pedagógico. É perceptível que, no nível baixo, mesmo com o pequeno número de escolas, há praticamente um equilíbrio na quantidade de escolas em cada tipo de uso.

As escolas que compõem os grupos que indicam os tipos de uso do SIMADE - administrativo e pedagógico - possuem características semelhantes em a relação à escolarização dos diretores (mais de $70 \%$ com pós-graduação), faixa etária predominante de 41 a 60 anos (cerca de $70 \%$ dos diretores), tempo na direção (aproximadamente $50 \%$ está em seu primeiro mandato) e não há diferença em relação ao conhecimento que os diretores têm sobre o SIMADE, vez que nos dois grupos o nível que sobressai é o intermediário.

No que concerne as características das escolas também há semelhança na localização (cerca de 90\% na zona urbana), infraestrutura (cerca de 90\% tem sala de diretor e sala de secretaria), embora nas unidades de ensino em que o tipo de uso é pedagógico a internet é considerada melhor (91,3\%) do que naquelas em que foi indicado o uso administrativo $(86,6 \%)$, bem como a quantidade de computadores de uso exclusivo para a parte administrativa é ligeramente maior do que naquelas em que foi indicado o uso pedagógico, pois a média a primeira é $7,4^{148}$ e a do segundo é $6,9^{149}$. O desempenho em Matemática, verificado por meio do indicador de desempenho apresentado no item 4. 1, mostra que a média das escolas que usam o sistema para o administrativo, $-0,0257^{150}$, é menor do que a das escolas que usam para o pedagógico, $0,0529^{151}$.

Portanto, as escolas que fazem uso pedagógico do SIMADE alcançam melhor desempenho em Matemática, dentro desse subgrupo. No entanto, não podemos afirmar que exista uma associação positiva entre o uso pedagógico do SIMADE e o desempenho dos discentes, pois outros fatores amplamente discutidos pela literatura, como por exemplo, a liderança do diretor, características do professor e suas ações didático-pedagógicas, origem social dos discentes,

\footnotetext{
148 Desvio padrão 4,596; mínimo 0 e máximo 27.

149 Desvio padrão 3,546; mínimo 0 e máximo 19.

${ }^{150}$ Desvio padrão 0,71477; mínimo -1,92 e máximo -1,82.

${ }^{151}$ Desvio padrão 0,73548; mínimo -1, 82 e máximo 2.
} 
infraestrutura física da escola, etc (OLIVEIRA \& PAES DE CARVALHO, 2018; BONAMINO, 2012; ALVES \& SOARES, 2008) podem ter um peso bem maior nesse resultado. Ainda assim, registramos como hipótese para futuros estudos que as escolas que usam o SIMADE para o pedagógico possam estar buscando assegurar a qualidade, associada a procura de sucesso educativo via aumento do desempenho discente, e a equidade intraescolar, uma vez que um mesmo conjunto de práticas escolares pode atuar, concomitantemente, aumentando o desempenho médio das escolas e promovendo a equidade entre os discentes (FRANCO et al., 2007).

O nível socioeconômico das escolas apresenta distribuição semelhante nos dois grupos. O grupo cujo tipo de uso do SIMADE é pedagógico apresenta um número de escolas com nível socioeconômico ligeiramente maior, o que poderia justificar seu melhor desempenho em matemática, vez que o nível socieconômico é uma variável que influencia no desempenho acadêmico dos discentes, conforme observado por Soares e Andrade (2006).

Finalmente, concluimos que, no contexto das escolas participantes dessa pesquisa, o SIMADE é considerado uma ferramenta de gestão, já que é uma das fontes de informação mais utilizadas dentro da escola, sendo que seu uso é predominantemente administrativo ou pedagógico. Entretanto, cabe observar, no tópico seguinte, a subjetividade dos diretores em relação ao uso dos dados do SIMADE, a partir dos níveis de autoeficácia.

\subsection{A autoeficácia do diretor e o uso dos dados do SIMADE}

Buscando observar quais têm sido os usos dos dados do SIMADE pelos diretores escolares, analisamos a questão" 152 "Você considera que os dados do SIMADE são úteis para:", composta de onze variáveis. O intuito desta análise foi observar o comportamento das respostas sobre o uso do SIMADE na percepção dos diretores e sua associação com os níveis de autoeficácia. A tabela a seguir apresenta a quantidade de respostas positivas por variável, ou seja, o número de diretores que assinalaram determinada variável dessa questão:

\footnotetext{
152 Perguntas fechadas que permitem aos respondentes selecionarem uma ou mais respostas em uma lista definida de opções.
} 
Tabela 18: Quantidade de respostas positivas por variável sobre uso dos dados e nível de autoeficácia.

\begin{tabular}{|c|c|c|c|c|c|c|}
\hline \multirow{3}{*}{ Variáveis } & \multicolumn{6}{|c|}{ Respostas por Nível de autoeficácia } \\
\hline & \multicolumn{2}{|c|}{1} & \multicolumn{2}{|c|}{2} & \multicolumn{2}{|c|}{3} \\
\hline & $\mathrm{N}$ & $\%$ & $\mathrm{~N}$ & $\%$ & $\mathrm{~N}$ & $\%$ \\
\hline $\begin{array}{l}\text { Planejar as metas e os objetivos da } \\
\text { escola }\end{array}$ & 47 & $\mathbf{5 1 , 6}$ & 262 & 66,7 & 69 & 67,6 \\
\hline $\begin{array}{l}\text { Orientar a distribuição de alunos } \\
\text { entre as turmas }\end{array}$ & 69 & $\mathbf{7 5 , 8}$ & 328 & 83,5 & 87 & 85,3 \\
\hline $\begin{array}{l}\text { Orientar a distribuição de professores } \\
\text { entre as turmas }\end{array}$ & 44 & 48,4 & 234 & 59,5 & 69 & 67,6 \\
\hline $\begin{array}{l}\text { Orientar a organização dos horários } \\
\text { escolares }\end{array}$ & 21 & 23,1 & 130 & 33,1 & 48 & 47,1 \\
\hline $\begin{array}{l}\text { Planejar atividades extracurriculares } \\
\text { na escola }\end{array}$ & 15 & 16,5 & 101 & 25,7 & 48 & 47,1 \\
\hline Melhorar o desempenho dos alunos & 34 & 37,4 & 227 & $\mathbf{5 7 , 8}$ & 69 & 67,6 \\
\hline $\begin{array}{l}\text { Organizar as reuniões pedagógicas } \\
\text { com os professores }\end{array}$ & 31 & 34,1 & 176 & 44,8 & 56 & 54,9 \\
\hline $\begin{array}{l}\text { Conversar com os professores sobre o } \\
\text { desempenho dos alunos }\end{array}$ & 53 & 58,2 & 302 & 76,8 & 80 & 78,4 \\
\hline $\begin{array}{l}\text { Criar estratégias para diminuir } \\
\text { a evasão escolar }\end{array}$ & 48 & 52,7 & 256 & 65,1 & 71 & 69,6 \\
\hline $\begin{array}{l}\text { Criar estratégias para diminuir a } \\
\text { reprovação }\end{array}$ & 48 & 52,7 & 250 & 63,6 & 70 & 68,6 \\
\hline $\begin{array}{l}\text { Criar estratégias de reforço para } \\
\text { alunos com dificuldades }\end{array}$ & 34 & 37,4 & 206 & 52,4 & 67 & 65,7 \\
\hline $\begin{array}{l}\text { Total de diretores por nível de } \\
\text { autoeficácia }\end{array}$ & 91 & - & 393 & - & 102 & - \\
\hline
\end{tabular}

Fonte: Questionário do diretor.

Essa questão se relaciona às atividades dos gestores escolares que podem ser realizadas com o auxílio de dados e/ou evidências fornecidas pelo SIMADE. Observa-se que o uso do SIMADE apresentado nas onze afirmativas é proporcional ao nível de autoeficácia, ou seja, aumenta-se gradativamente o total e o percentual de respostas que indicam o uso dos dados conforme o nível de autoeficácia. Além disso, as variáveis que aparecem com maior porcentagem no nível 1 (baixa autoeficácia) se mantêm até o nível 3 (alta autoeficácia), embora os níveis 2 e 3 (autoeficácia adaptativa e alta) possuam praticamente as mesmas variáveis como as mais assinaladas pelos diretores.

Mesmo assim, é possível perceber certos usos dos dados do SIMADE mais presentes no cotidiano dos diretores escolares, quais sejam: (i) "Orientar a distribuição de alunos entre as turmas", que possui o maior percentual nos três níveis; (ii) conversar com os professores sobre o desempenho dos alunos, com percentuais próximos nos níveis dois e três; (iii) e criar estratégias para diminuir a evasão escolar e criar estratégias para diminuir a reprovação. 
Embora não possamos afirmar que essas respostas ilustram o uso administrativo ou pedagógico do SIMADE, pois isso depende da forma como os diretores interpretam e compreendem cada ação, difícil de captar pelo survey, essas respostas parecem indicar uma perspectiva de planejamento estratégico, ou seja, o desenvolvimento de "um plano de ação que define as estratégias de curto, médio e longo prazo, para garantir a melhoria da aprendizagem dos alunos e de outros indicadores de desempenho" (NEUBAUER; SILVEIRA, 2009, p.104).

$\mathrm{Na}$ direção escolar, o planejamento estratégico pode ser compreendido como "a capacidade do gestor de pensar a realidade, as necessidades e as ações da organização de forma articulada com os condicionantes internos e externos da organização e com os objetivos de curto, médio e longo prazo" (MIRANDA; MACHADO, 2013, p.5). Este planejamento permite identificar as necessidades de mudanças, as prioridades e os meios para efetivá-las. Soma-se a isso o fato do planejamento envolver a capacidade de organização da escola e das pessoas que integram a instituição de ensino, com vistas a desenvolver ações estratégicas pautadas no currículo, Projeto Político Pedagógico (PPP), etc. (PARRA \& MATUS, 2016). Para as autoras "contar con una definición clara y compartida de los sentidos y objetivos, le permite a la escuela crear una visión y normas en torno al uso de datos que promueva el desarrollo tanto de la escuela como de los actores que la conforman" (PARRA \& MATUS, 2016, p. 230).

Dessa forma, o planejamento permite ter clareza sobre os sentidos e propósitos que devem orientar o uso dos dados para o cumprimento dos instrumentos - currículo e PPP - com vistas a melhorar o rendimento e desempenho discente. Entretanto, além do planejamento das ações cabe ao diretor desenvolver uma rotina de uso dos dados, pois conforme observado por Datnow e Schildkamp (2019) a rotina ajuda a promover ações coordenadas com eficiência, além de definir quem é responsável por determinada tarefa e como ela deve ser executada.

Torna-se relevante o fato de os diretores informarem (na questão "Indique com que frequência você utiliza os dados do SIMADE para...”) que atividades relativas às variáveis Criar estratégias para diminuir a evasão escolar, Criar estratégias para diminuir a reprovação e Planejar as metas e os objetivos da escola são as mais registradas como de periodicidade mensal, sinalizando para uma atenção regular para estas questões. 
Compreendendo que o ser humano não é apenas um produto de relações de troca com o ambiente, segundo Iaochite (2017), parafraseando Bandura (2001), eles têm entre suas capacidades a de antecipar - "planejamento de linhas de ação, estabelecimento de objetivos e antecipação de possíveis consequências das ações planejadas" (IAOCHITE, 2017, p. 14); simbolizar - "armazenar informações para orientar comportamentos futuros e modelar comportamentos observados" (IAOCHITE, 2017, p. 14); e a capacidade de refletir sobre si mesmo - "atribuir sentido às próprias experiências, crenças, valores pessoais, autoavaliando a si próprio e criando oportunidades de alterar (ou não) o curso do comportamento realizado" (IAOCHITE, 2017, p. 14), ou seja, eles têm comportamentos que modificam o ambiente, como, por exemplo, planejar algo, conversar para decidir ou compartilhar uma ação ou buscar melhorias no desempenho discente.

$\mathrm{Na}$ esteira desse raciocínio, conversar com os professores sobre o desempenho dos alunos e melhorar o desempenho dos alunos pode estar indicando que esses diretores tomam decisões compartilhadas, ou seja, que "pressupõem o envolvimento dos atores sociais no processo de tomada de decisão acerca das diversas demandas atribuídas à escola, sobretudo daquelas voltadas para a formação dos educandos" (LEAL \& NOVAES, 2018, p. 4).

Cabe ressaltar que os diretores que estão no nível baixo de autoeficácia, podem não compreender totalmente a utilização dos dados do SIMADE. Parra e Matus (2016) apontam resultado semelhante em relação ao uso dos dados de avaliação externa no Chile e elencam aspectos, que também se enquadram nessa pesquisa, que podem dificultar esse entendimento e a identificação de que: os dados são adequados e necessários; é preciso analisar e dar sentido aos dados de maneira pertinente e contextualizada; é necessário avaliar a eficácia das ações implementadas a partir dos dados (PARRA \& MATUS, 2016).

A seguir, a tabela que apresenta a frequência de uso dos dados do SIMADE pelos diretores escolares: 
Tabela 19: Indique com que frequência você utiliza os dados do SIMADE para:

\begin{tabular}{|c|c|c|c|c|c|c|}
\hline & Nunca & $\begin{array}{l}\text { Uma vez } \\
\text { por ano }\end{array}$ & $\begin{array}{c}\text { De } 3 \text { a } 4 \\
\text { vezes ao } \\
\text { ano }\end{array}$ & $\begin{array}{l}\text { Mensalm } \\
\text { ente }\end{array}$ & $\begin{array}{l}\text { Semanal } \\
\text { mente }\end{array}$ & Total \\
\hline $\begin{array}{l}\text { Elaborar relatórios e ofícios } \\
\text { para a SER }\end{array}$ & $13,6 \%$ & $10,5 \%$ & $33,3 \%$ & $28,6 \%$ & $13,9 \%$ & $100 \%$ \\
\hline $\begin{array}{l}\text { Contratar funcionário para } \\
\text { atendimento de aluno de AEE }\end{array}$ & $11,6 \%$ & $43,3 \%$ & $30,4 \%$ & $9,2 \%$ & $5,4 \%$ & $100 \%$ \\
\hline $\begin{array}{l}\text { Verificar alunos que } \\
\text { necessitam de condução } \\
\text { escolar }\end{array}$ & $27 \%$ & $27,5 \%$ & $21 \%$ & $18,3 \%$ & $6,2 \%$ & $100 \%$ \\
\hline $\begin{array}{l}\text { Verificar evasão e abandono } \\
\text { discente }\end{array}$ & $4,2 \%$ & $5,1 \%$ & $15,9 \%$ & $43,7 \%$ & $31,2 \%$ & $100 \%$ \\
\hline $\begin{array}{l}\text { Investigar as causas do baixo } \\
\text { desempenho discente }\end{array}$ & $12,5 \%$ & $4,9 \%$ & $29,3 \%$ & $40,4 \%$ & $12,9 \%$ & $100 \%$ \\
\hline $\begin{array}{l}\text { Elaborar um plano de metas e } \\
\text { ações para intervenções } \\
\text { pedagógicas }\end{array}$ & $12,1 \%$ & $10,9 \%$ & $36,8 \%$ & $31,5 \%$ & $8,7 \%$ & $100 \%$ \\
\hline
\end{tabular}

Constata-se que o uso dos dados do SIMADE em atividades que parecem ter um caráter mais administrativo - Elaborar relatórios e ofícios para a SRE, Contratar funcionários para atendimento de alunos de AEE e Verificar alunos que necessitam de condução escolar - é realizado em momentos pontuais do ano, pois seus maiores percentuais estão na opção de resposta de 3 a 4 vezes ao ano ou uma vez por ano. Verificar evasão e abandono discente e Investigar as causas do baixo desempenho discente, apesar de se remeterem a atividades de caráter administrativo, possuem os maiores percentuais na opção de resposta mensalmente, deixando a hipótese de que os diretores compreendem essas duas variáveis como um aspecto pedagógico. Já Elaborar um plano de metas e ações para intervenções pedagógicas, caracterizaria um uso mais pedagógico, embora apresente um percentual inferior do que as duas variáveis mencionadas anteriormente.

Portanto, embora não possamos afirmar como os diretores interpretam esses dados, parece que, no cotidiano escolar, há uma volatilidade na indicação do que é administrativo e pedagógico. Soma-se a isso o fato dos dados do SIMADE serem utilizados ao longo do ano escolar, pois há uma variabilidade de ações desempenhadas pelo diretor que podem ser executadas em momentos específicos do ano escolar ${ }^{153}$, como por exemplo, início do ano letivo, e outras com mais frequência, isto é, mensalmente ou diariamente, dependendo do trabalho que se pretende desenvolver usando esses dados ou a partir deles.

\footnotetext{
${ }^{153}$ A diferença entre ano escolar e ano letivo e que o primeiro se inicia com o planejamento das atividades e reuniões pedagógicas enquanto o segundo se inicia com o início das aulas.
} 
Cada variável da questão "Considerando o seu trabalho na direção desta escola, marque qual é o seu nível de concordância com cada uma das afirmativas abaixo", composta por quatro variáveis e respostas apresentadas em escala Likert (discordo totalmente até concordo totalmente), foi utilizada como variável dependente e o indicador de autoeficácia como variável independente. Constatouse que há diferença nas médias de respostas entre os três níveis de autoeficácia ${ }^{154}$, indicando que há associação entre o indicador de autoeficácia e as variáveis Considero a utilização do SIMADE bastante fácil, Estou bastante confiante na minha capacidade para utilizar o SIMADE e O SIMADE me ajuda a poupar tempo na realização de minhas atividades, nos níveis 2 e 3 (autoeficácia adaptativa e alta). A exceção foi a variável "Utilizar o SIMADE é algo que raramente gosto"

Isto indica que, nessas variáveis e nos referidos níveis, existe um grau mais elevado de confiança dos diretores em sua capacidade para usar o sistema e que eles o reconhecem como um instrumento que pode auxiliar a poupar tempo nas atribuições da gestão. Dessa forma, podemos concordar com Piedade e Pedro (2014) que as crenças pessoais dos diretores podem promover melhores práticas de utilização das tecnologias na gestão escolar. Por fim, apresentamos graficamente as médias de cada um dos três grupos de diretores para as variáveis dependentes que se mostraram significativas na associação entre autoeficácia e o uso do SIMADE no cotidiano:

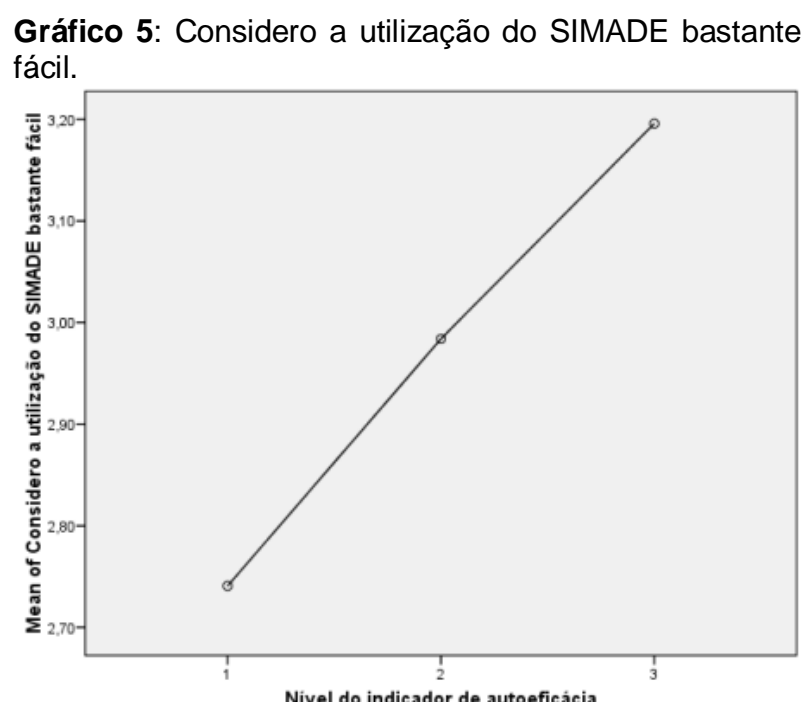

Fonte: Questionário do diretor.

${ }^{154}$ Ver mais detalhes no anexo 9.

${ }^{155}$ A tabela e o gráfico que apresentam esses resultados estão no anexo 9. 
Gráfico 6: Estou bastante confiante na minha capacidade para utilizar o SIMADE

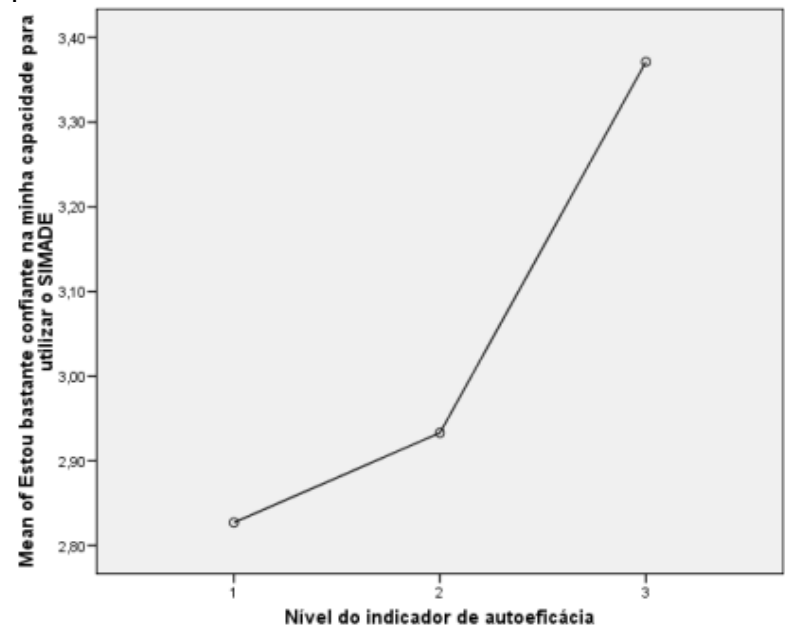

Fonte: Questionário do diretor

Gráfico 7: O SIMADE me ajuda a poupar tempo na realização de minhas atividades

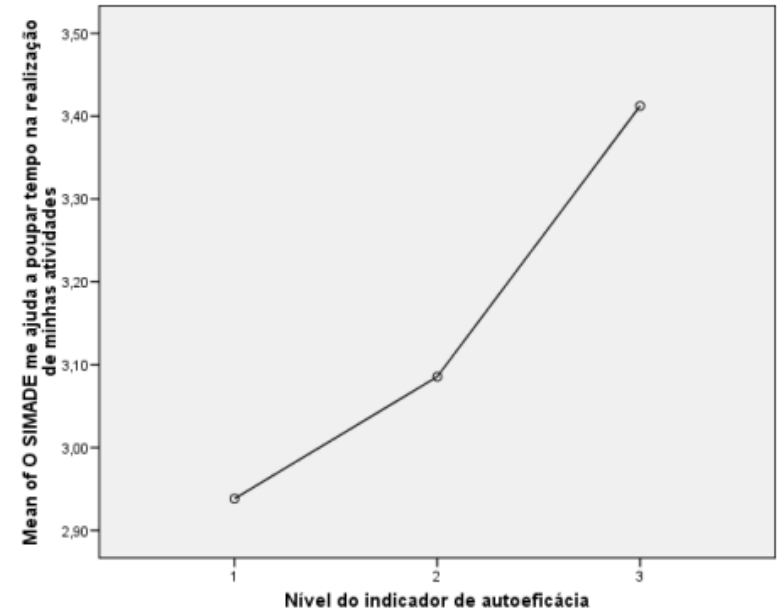

Fonte: Questionário do diretor

Observamos, em cada um dos três últimos gráficos, um padrão ascendente, indicando que, quanto maior o nível de autoeficácia, mais o diretor se sente confiante em utilizar o SIMADE.

Portanto, o indicador de autoeficácia nos permitiu verificar a percepção dos diretores sobre os seus níveis de autoeficácia, bem como sua relação com as atividades diárias do diretor e o uso do SIMADE. Além disso, constatou-se que o tipo de uso do SIMADE nas escolas é administrativo ou pedagógico e que isso reflete na forma como os diretores percebem e usam os dados do sistema, embora 
as unidades de ensino tenham características semelhantes (como, por exemplo, localização) e diferentes (como desempenho em matemática e nível socioeconômico dos alunos). As escolas em que os diretores se percebem mais autoeficazes também são aquelas que os gestores mais usam os dados do SIMADE e consideram o sistema fácil de usar. 


\section{CONSIDERAÇÕES FINAIS}

Quais têm sido os usos dos dados como ferramenta de gestão pelos diretores de escolas públicas/ Em particular quais têm sido os usos do Sistema Mineiro de Administração Escolar (SIMADE) como ferramenta de gestão para os diretores das escolas públicas da rede estadual de Minas Gerais? A partir dessa questão central, buscou-se ampliar a compreensão em relação ao uso dos dados do SIMADE, com enfoque diferente do predominante nas pesquisas nacionais e internacionais sobre sistema de gestão escolar, inclusive nos estudos sobre o SIMADE, ao utilizar apenas a abordagem quantitativa para investigar um sistema de gestão escolar público implementado em escolas de uma rede estadual.

Os estudos internacionais (DEMIR, 2006; IRVING \& GAN, 2012; BLAU \& PRESSER, 2013; CUNHA, 2013; SHAH, 2014; STARKEY \& EPPEL, 2017) e nacionais (FREIRE \& BASTOS JÚNIOR, 2013, CAVALCANTE et al., 2016; GONZAGA \& HANSEN, 2016; COSTA JÚNIOR, 2012; ; SPECK et al., 2018) afirmam que os sistemas de gestão escolar facilitam a busca e análise das informações sobre rendimento e desempenho discente, facilitando a busca e a análise das informações educacionais, padronizando as tarefas e otimizando os processos administrativos e o monitoramento da aprendizagem. O sistema é compreendido como um recurso, uma ferramenta essencial para o processo de tomada de decisão e para a organização da unidade de ensino.

As pesquisas sobre o SIMADE (BALDUTI, 2017; TOMAZ, 2015; FONSECA, 2014; SALGADO, 2014; MARTINS, 2014) reconhecem, a partir da percepção dos sujeitos das pesquisas (diretores, secretários escolares e profisssionais das SREs), o avanço no tratamento dos dados educacionais, a otimização do tempo no preenchimento dos dados e a importância dos relatórios e documentos extraídos pelo sistema. Porém, não apresentam efetivamente o uso dos dados por parte dos agentes escolares, observando apenas algumas funcionalidades do sistema que são utilizadas nas escolas.

Aplicamos um survey ao conjunto das escolas públicas da rede estadual de ensino de Minas Gerais, tendo obtido respostas de diretores e secretários (ou ATBs) de 586 escolas. Analisando as características (quanto à localização, matrículas, etapas de ensino ofertadas, etc.) das escolas em que obtivemos respostas tanto dos diretores, como dos secretários (ou ATBs) e as características do conjunto das 
escolas da rede estadual mineira observamos que a amostra de 586 escolas da pesquisa foi muito similar ao conjunto das 3.444 escolas estaduais mineiras. Constatou-se que entre as escolas que compõem a amostra da pesquisa predominavam escolas localizadas na zona urbana, situadas em municípios de médio e pequeno porte, que funcionam nos turnos da manhã e tarde para atender aos alunos do Ensino Fundamental II e Ensino Médio ou Ensino Fundamental I e II e Ensino Médio. Embora não seja uma amostra representativa das escolas de Minas Gerais, representa um subconjunto da população que possui características semelhantes com as demais escolas de Minas Gerais, o que nos conduziu a assumir a provável generalidade dos achados da pesquisa.

As análises descritivas, realizadas a partir dos resultados dos 586 questionários dos diretores e secretários escolares e também de dados da Prova Brasil de 2015, do SIMAVE $2016^{156}$ e do Censo Escolar de 2016, possibilitaram caracterizar as escolas, os sujeitos da pesquisa e a infraestrutura tecnológica. A análise descritiva também apresentou algumas características dos sujeitos da pesquisa - diretores, secretários e ATBs - como a predominância de mulheres, da cor branca ou parda, com média de idade de 40 anos e que consideram que existe uma boa relação entre a direção e a equipe da secretaria da escola. A análise também descortinou algumas diferenças entre esses profissionais como a forma de provimento do cargo, o tempo de atuação na docência e na atual função, escolarização e funções dentro da escola. Constatamos também que, embora no cotidiano os diretores dediquem considerável parte de seu tempo à gestão administrativa, têm um nível de conhecimento para utilizar o SIMADE inferior quando comparado ao dos secretários e ATBs

A análise descritiva de questões sobre o SIMADE constatou uma percepção positiva da infraestrutura tecnológica disponível nas escolas - computadores, internet e acesso ao sistema. Por outro lado, as respostas de diretores e equipe da secretaria indicaram diferentes compreensões sobre a sua responsabilidade em relação ao sistema, sendo os secretários e ATBs os responsáveis pelo preenchimento e atualização do sistema dentro da instituição de ensino

\footnotetext{
${ }^{156}$ A média dos resultados dos dois anos busca contornar um possível viés dos resultados de um dos anos (uma turma de determinado ano que teve resultados excepcionais que não refletiriam a proficiência média da escola, por exemplo). Assim a média se aproximaria mais do resultado médio (real) da escola.
} 
(contrariando o estabelecido na Resolução 1.180 de 28 de agosto de 2008 que atribui ao diretor essa responsabilidade). Estas respostas parecem apontar uma repartição pragmática de atribuições no plano das escolas, em que a secretaria assume praticamente a integralidade da responsabilidade pela alimentação do sistema e a direção assumiria uma postura de supervisão do processo, possivelmente expressando uma percepção hegemônica do mesmo enquanto atividade fundamentalmente administrativa.

Secretários e ATBs possuem uma percepção positiva do sistema em relação a usabilidade, funcionalidade, confiabilidade e eficiência, embora as respostas aos questionários tenham apresentado alguns indicativos para melhorar estes aspectos no SIMADE. No que concerne a formação apenas 39,5\% dos diretores e 55,8\% dos secretários e ATBs afirmaram ter participado de cursos sobre o SIMADE, nos quais foi abordada a atualização do cadastro dos alunos, das matrículas, a alocação dos alunos nas turmas (enturmação), a inserção dos dados das avaliações, da frequência e do histórico escolar. A participação em cursos do SIMADE pode ter influenciado na capacidade de realizar tarefa usando o SIMADE.

No que concerne à autoeficácia o primeiro passo foi a criação de um indicador que permitisse "medir" a percepção de autoeficácia do diretor. O objetivo era trabalhar com uma única medida sintética que permitisse realizar outras análises empíricas sobre o uso dos dados do SIMADE. Para isso foram selecionadas - com base na literatura de referência pesquisas (GUERREIRO-CASANOVA, 2014; 2015; GUERREIRO-CASANOVA \& RUSSO (2016); TSCHANNEN-MORAN \& GAREIS, 2004) - três variáveis (Planejar e cumprir as atividades de seu trabalho; Resolver os problemas burocráticos de seu trabalho; e Apoiar o trabalho pedagógico dos professores) da questão "Em sua função de diretor, o quanto você consegue...", que julgamos mais pertinentes de serem utilizadas nesta pesquisa. A estatística descritiva da análise fatorial para o cálculo do indicador de autoeficácia do diretor resultou em três níveis/grupos, Baixo (com 91 diretores ou 15,5\% do total de respondentes), Adaptativo (393 respostas ou 67\% do total) e Alto (102 respostas ou $17,4 \%$ do total de diretores).

Segundo Iaochite (2017), a autoeficácia influencia na escolha das "metas que as pessoas escolhem para si próprias, o quanto de esforço elas despenderão para realizá-las, o quanto serão perseverantes diante dos desafios e o quanto serão resilientes diante dos fracassos" (p. 17). Na pesquisa buscamos associações entre a 
autoeficácia e características pessoais, como a idade; resultados escolares, como o desempenho dos discentes em matemática; uso de fontes de informação e tarefas realizadas pelos diretores em seu cotidiano. Com exceção da última característica (tarefas realizadas pelos diretores da escola no cotidiano) os resultados se mostraram não significativos para uma associação com o nível de autoeficácia do diretor. Em relação as tarefas realizadas pelos diretores em seu cotidiano percebemos que a realização e consequentemente, uma provável maior valorização, das tarefas pedagógicas como as atividades voltadas para a promoção da aprendizagem, a preocupação com o rendimento e o desempenho discentes são executadas por diretores que possuem níveis adaptativo ou alto de autoeficácia.

No que se refere aos usos do SIMADE, as respostas dos diretores às perguntas abertas sobre o tema no survey mostraram que 261 deles $(65,4 \%)$ usam o sistema para as tarefas administrativas como inserir e atualizar informações, enquanto que $138(34,5 \%)$ o utilizam para o pedagógico ${ }^{157}$. O primeiro tipo de uso indicado mostra uma ênfase no cumprimento da resolução da SEE/MG (1180/2008) que impõe esse uso do SIMADE como parte do monitoramento da gestão (escolar e central) sobre a unidade de ensino, na medida em que possibilita a padronização dos processos administrativos e viabiliza o controle (central e regionalizado) do que ocorre (em termos de fluxo de alunos, necessidades de professores, etc.) nas unidades escolares da rede.

Já o uso que caracterizamos como pedagógico estaria voltado para otimizar a função da escola enquanto espaço de garantia do direito à educação, buscando assegurar o acesso ao conhecimento. Nesse tipo de uso, as informações disponibilizadas pelo sistema seriam compreendidas como um recurso para desenvolver o trabalho pedagógico, influenciando a distribuição dos alunos entre as turmas, subsidiando discussões com o corpo docente ou ainda a definição de ações escolares de combate ao abandono e à repetência, por exemplo.

Cabe ressaltar que, embora em todos os níveis de autoeficácia predomine o tipo de uso do SIMADE voltado para o trabalho administrativo, as escolas em que os diretores afirmam fazer uso pedagógico do sistema alcançam melhor desempenho médio em Matemática e possuem nível socioeconômico ligeiramente maior do que as escolas que usam o sistema para o administrativo. A associação

\footnotetext{
157 O total de respostas é 399, pois 137 diretores responderam Sim (96) ou Não(41) não informando o uso do SIMADE e outros 50 não responderam a questão.
} 
entre o uso pedagógico do SIMADE, os resultados de desempenho e o nível socioeconômico médio, deve remeter, necessariamente, a novas investigações a fim de isolar estes fatores ou ao menos compreender melhor estas interações.

Ainda no que concerne aos tipos de uso do SIMADE, constatamos que quanto maior o nível de autoeficácia mais os diretores usam os dados do SIMADE para planejar ações, ou seja, as diferenças encontradas entre os níveis de autoeficácia em relação ao uso dos dados do SIMADE parecem estar relacionadas também ao planejamento escolar ou a percepção dos diretores sobre ele em termos da necessidade de informações objetivas para sustentar o diagnóstico da realidade escolar e o desenho estratégico e consistente de ações na escola.

Os resultados do estudo também nos permitiram constatar que as hipóteses “As formas de uso do SIMADE no nível da escola estão relacionadas a autoeficácia do gestor escolar" e "A usabilidade do SIMADE influencia no uso dos dados pela escola" são verdadeiras; e que a pesquisa apresenta alguns limites na investigação realizada, bem como questões que deverão, no futuro, merecer aprofundamento e outros estudos.

Um primeiro aspecto que nos chamou a atenção foi a possibilidade de um viés nas respostas obtidas no survey em razão da estratégia escolhida para a aplicação do instrumento. Adotamos uma pesquisa do tipo survey que "se refere a um tipo particular de pesquisa social e empírica" (BABBIE, 2001, p. 65), que permite a verificação de traços e atributos a uma determinada população, a fim de realizar afirmações explicativas sobre o fenômeno pesquisado. Frequentemente os surveys são empreendidos para compreender aspectos de uma população maior do que a amostra selecionada, possibilitando a generalização dos resultados.

Os questionários foram elaborados buscando "transformar conceitos teóricos geralmente abstratos e complexos em indicadores concretos e verificáveis na realidade constitui uma condição necessária para a construção de qualquer questionário" (LINHARES \& ALVES, 2014, p. 28). Como já relatado no capítulo 2, foi realizado um extenso estudo envolvendo o pré-teste das questões antes de chegarmos ao formato final que foi então enviado a toda a rede pública estadual de educação, com a autorização da SEE-MG. Esta colaboração da SEE/MG para a realização da pesquisa, enviando às SREs e escolas uma autorização bem descritiva sobre o estudo e o instrumento a ser aplicado nas unidades de ensino pode ter influenciado as respostas obtidas e poderia explicar, ao menos em parte, a pouca 
variabilidade de algumas respostas. A participação da SEE/MG pode ter induzido os respondentes a registrar aquilo que acreditavam que a SEE/MG "gostaria de ouvir". Ou seja, pode ter ocorrido um viés, definido por Almeida e Goulart (2017) "como qualquer processo, em qualquer etapa da pesquisa, em que a metodologia incorreta durante o curso da investigação distorce o resultado. Viés inclui toda e qualquer distorção durante o processo de investigação, que pode ocorrer em qualquer tipo de delineamento" ( p. 553).

Esse viés pode ter ultrapassado o grau de concordância entre as respostas dos diretores, secretários e ATBs, refletindo-se também no número de questionários respondidos, uma vez que algumas escolas podem ter ficado "inibidas" de expor suas reais opiniões em relação ao SIMADE, preferindo não responder ao instrumento ou respondê-lo de forma incompleta. Como agentes das escolas, diretores, secretários e ATBs podem ter descrito o SIMADE, privilegiando seus pontos positivos, assim como enaltecendo sua percepção sobre a autoeficácia.

No entanto, não podemos precisar a magnitude do viés, vez que, nas entrevistas para validar os questionários, as respostas dos diretores foram semelhantes às informadas nos instrumentos, podendo ser, portanto, um indício de que nem todos os respondentes se sentiram intimidados em expor suas opiniões em relação ao uso dos dados do SIMADE.

Por estas razões, em que pese o tamanho da amostra, bem como a semelhança das características das escolas que a compuseram com o conjunto da rede estadual mineira, os resultados podem não representar completamente todas as diferentes formas de usar e conceituar os tipos de uso do SIMADE. Estudos adicionais devem ser realizados para examinar com mais profundidade a variação desse uso. Além disso, é importante ressaltar que tais resultados não podem ser generalizados para outros softwares de gestão escolar, devido às especificidades do SIMADE - aplicado em uma rede estadual; utilizado por diretores, secretários e ATBs, seguir as legislações nacionais e de Minas Gerais, etc.

As aplicações dos questionários ocorreram sem intercorrências ou comunicações, via e-mail, que relatassem dúvidas por parte dos respondentes ou estabelecessem explicitamente alguma resistência em responder aos questionários. Ainda assim, após os três meses de aplicação dos instrumentos (tempo que, em pesquisas futuras, poderia ser reavaliado), obtivemos respostas de $17 \%$ das escolas públicas estaduais de Minas Gerais. 
Levantamos a hipótese de que se tivéssemos podido adotar a triangulação de métodos conforme utilizado por outras pesquisas sobre o SIMADE (BALDUTI, 2017; TOMAZ, 2015; FONSECA, 2014), talvez tivesse sido possível aprofundar a análise de algumas questões de interesse já identificadas na pesquisa quantitativa, como a possível associação entre o SIMADE e a qualidade e equidade no contexto escolar.

Reconhece-se também que uma das limitações deste estudo foi não ter encontrado mais variáveis positivamente associadas ao nível de autoeficácia dos diretores. Supomos que novas pesquisas, de cunho qualitativo possam contribuir nessa direção, assim como subsidiar programas de formação em serviço para o uso do sistema. No nível macro, por outro lado, acreditamos que este esforço de pesquisa pode ajudar aos órgãos superiores - SREs e SEE/MG - a melhor definir as características dos usuários do sistema - diretor, secretário e ATB -, que informem a proposição de melhorias no sistema a partir das variáveis de contexto e de atividades que indiquem baixa ou adaptativa autoeficácia desses profissionais.

Para as pesquisas futuras propomos a inserção de novas questões no questionário que possibilitem captar a relação entre a liderança do diretor e a autoeficácia. Este aspecto se mostra especialmente relevante na medida em que inúmeras pesquisas internacionais ${ }^{158}$ e nacionais ${ }^{159}$ sobre eficácia escolar - usando abordagens quantitativas e qualitativas - identificaram a liderança do diretor como uma das características dos estabelecimentos de ensino que promoviam o sucesso e o progresso escolar (OLIVEIRA \& PAES DE CARVALHO, 2015; BONAMINO, 2012; SAMMONS, 2008). De fato, a literatura especializada, especialmente a internacional, tem reconhecido a liderança do diretor e sua dedicação como características cruciais à eficácia escolar.

Quase todos os estudos de eficácia escolar mostram a liderança como fator chave, tanto na escola primária quanto na secundária. Gray (1990) diz que a importância da liderança dos diretores é uma das mensagens mais claras da pesquisa em eficácia escolar. [...] o estudo da literatura revela que três características foram encontradas frequentemente associadas à liderança de sucesso: propósito forte, envolvimento de outros funcionários no processo decisório, e autoridade profissional nos processos de ensino e aprendizagem (SAMMONS, 2008, pp. 351-352).

\footnotetext{
${ }^{158}$ Para saber sobre as outras dez características das escolas eficazes, consulte Sammons (2008).

159 Para saber sobre as outras quatro características das escolas eficazes no contexto brasileiro, consulte Alves e Franco (2008).
} 
A liderança do diretor da escola voltada para o trabalho pedagógico e os resultados escolares é considerada fator determinante para o sucesso escolar, já que a questão pedagógica é destacada como abrangendo "práticas de gestão que têm como objetivo a melhoria do processo de ensino e aprendizagem, enfatizando a aquisição de conhecimento pelos alunos e respectiva monitorização, dando particular atenção à supervisão do currículo e a eficácia das práticas dos professores" (COSTA; CASTANHEIRA, 2015, p. 34).

Um diretor que confia em sua capacidade para produzir os resultados desejados na escola em que atua exerce sua liderança de modo a possibilitar um ambiente que promova estimulação intelectual e estabeleça altas expectativas de desempenho (GUERREIRO-CASANOVA \& RUSSO, 2016). Nessa perspectiva, pode-se supor que a autoeficácia do gestor deva ser positivamente associada à promoção de ações no âmbito da escola que busquem promover alterações voltadas para elevar o desempenho discente nas avaliações em larga escala (GUERREIROCASANOVA \& AZZI, 2012). Nessa direção, novas pesquisas, em particular de cunho mais qualitativo, poderiam sustentar de forma mais consistente e contextualizada a elaboração de itens para a composição do índice de autoeficácia, inclusive considerando as diferentes dimensões da gestão escolar, como os aspectos instrucionais e a liderança moral, por exemplo.

Soma-se a isso a necessidade de aperfeiçoar o olhar sobre as condições de trabalho da direção da escola e ao conteúdo de sua formação e experiência profissional anterior ao cargo, que podem influenciar sua autoeficácia. Ainda nesta perspectiva, seria provavelmente importante considerar também as relações entre diretores e os agentes educacionais que lhe são imediatamente superiores hierarquicamente (SREs no caso de Minas Gerais) e os que atuam com eles no nível das escolas (professores, secretários e ATBs). Como, desde 2017, professores e supervisores escolares são usuários do SIMADE, podendo acessar alguns módulos do sistema, eles teriam condições tanto de opinar sobre o uso dos dados do SIMADE como também sobre a atuação do diretor exerce e suas relações de colaboração com a equipe administrativa da escola. A introdução de novos atores no âmbito de uma pesquisa sobre este sistema e sobre o uso dos dados como ferramenta de gestão poderá trazer um novo olhar sobre a questão investigada nesse estudo, bem como outras descobertas sobre o tema. 
Finalmente, cabe assinalar a possibilidade de outras pesquisas que discutam mais diretamente a qualidade da educação a partir dos dados fornecidos pelo SIMADE. Compreendendo que o sistema possui um grande banco de dados do sistema educacional mineiro, o acesso a tais informações possibilitaria observar, principalmente, os fatores intraescolares das unidades de ensino que compõem a amostra da pesquisa em tela. Nesse sentido, podemos observar a quantidade de aulas efetivamente ministradas; projetos extracurriculares; corpo docente; direção escolar, frequência; rendimento escolar; repetência; distorção idade-série, desempenho discente, raça e gênero dos estudantes, etc.

Outro dado relevante que pode ser observado é a composição das turmas (enturmação), que além de refletir aspectos demográficos da comunidade do entorno da escola é também influenciado pela forte segmentação dos filtros socioeconômicos e culturais que produzem um efeito de seleção da escola. Alves e Soares (2007) em artigo que discute a relação entre escolas e estratificação social, concluem que "dependendo do critério de formação das turmas, as pequenas diferenças são acirradas e contribuem para a estratificação interna nas escolas" (ALVES \& SOARES, 2007, p. 43). Como o SIMADE oferece quatro opções de enturmação (alfabética, por código, masculino primeiro e feminino primeiro) podem-se verificar as diferenças nas turmas e mesmo analisar se a escola utiliza algum outro critério de enturmação.

Concluímos, portanto, que a pesquisa trouxe avanços importantes, possibilitando ao apresentar os tipos de uso do SIMADE, relacionar o uso dos dados do SIMADE com a autoeficácia do gestor escolar e verificar que a usabilidade do SIMADE influencia no uso dos dados pela escola. Além disso, ofereceu hipóteses instigantes para novos estudos sobre a complexidade da gestão escolar e os fatores que podem sustentar sua eficácia na busca do sucesso escolar como um direito de todos os estudantes. 


\section{Referências bibliográficas}

ABUD, C. de C. R. A função do secretário escolar na contemporaneidade: entre memórias e arquivos escolares. Mato Grosso do Sul. Revista Linguagem Educação e Memória. v. 3, n. 3 (2012). Disponível em: $<$ https://periodicosonline.uems.br/index.php/WRLEM/article/download/2084/pdf. $>$ Acesso em: 08 jul 2018.

ALMEIDA, M. E. B. de; SILVA, M. da G. M. da. Currículo, tecnologia e cultura digital: espaços e tempos de web currículo. Revista e-curriculum, São Paulo, v.7 n.1 abril/2011.

ALMEIDA, M. E. B. de. Gestão de tecnologias na escola: possibilidades de uma prática democrática. Integração de tecnologias, linguagens e representações. Brasil, boletim 5, maio, 2005, p 15-24. Disponível em:

$\langle$ http://tvbrasil.org.br/fotos/salto/series/145723integracaotec.pdf $>$ Acesso em: 10 nov 2014.

ALMEIDA, C. P. B. de ; GOULART, B. N. G. de. Como minimizar vieses em revisões sistemáticas de estudos observacionais. Rev. CEFAC. 2017 Jul-Ago; 19(4):551-555 . Disponível em: <http://www.scielo.br/pdf/rcefac/v19n4/pt 19820216-rcefac-19-04-00551.pdf >Acesso em: 04 jan 2019.

ALMEIDA, V. L.da F.a; SOUZA, A. M. de; OLIVEIRA, P. N. O. A profissão e atuação do secretário escolar no ensino público e privado em escolas de São Sebastião-DF. Revista de Gestão e Secretariado - GeSec, São Paulo, v. 4, n. 3, p 83-109, dez. 2013. Disponível em: $\leq$ https://www.revistagesec.org.br/secretariado/article/view/195/pdf 46> Acesso em: 13 jun 2018.

ALMEIDA, J. G.; NHOQUE, J. R. Avaliação em larga escala na escola: repercussões e desdobramentos no trabalho escolar. REAe - Revista de Estudos Aplicados em Educação, v. 2, n. 4, jul./dez. 2017. Disponível em:< http://seer.uscs.edu.br/index.php/revista_estudos_aplicados/article/view/4781/234 0> Acesso em: 18 jan 2019.

ALONSO. M.. Formação de Gestores Escolares: Um campo de Pesquisa a ser Explorado. In: ALMEIDA, Maria Elizabeth Bianconcini de; ALONSO, Myrtes. (Orgs.). Tecnologias na Formação e na Gestão Escolar. São Paulo: Avercamp, 2007.

ALVARENGA, C. A.; AZZI, R. G.. Autoeficácia computacional docente e o uso didático de tecnologias de informática. Conference: Actas do I Encontro Internacional TIC e Educação. Inovação curricular com TIC, At Lisboa - Portugal. Disponível

em:

$<$ https://www.researchgate.net/publication/256325790 Autoeficacia computacion al_docente_e_o_uso_didatico_de_tecnologias_de_informatica/>Acesso em: 18 jul 2017. 
ALVES, M. T. G.; SOARES, J. F.. As Pesquisas sobre o Efeito das Escolas: contribuições metodológicas para a Sociologia da Educação. Sociedade e Estado, Brasília, v. 22, n. 2, pp. 435-473, mai/ago 2007.

O efeito das escolas no aprendizado dos alunos: um estudo com dados longitudinais no Ensino Fundamental. Educação e Pesquisa, São Paulo, v.34, n.3, p. 527-544, set./dez. 2008. Disponível em: <http://www.scielo.br/pdf/ep/v34n3/v34n3a08.pdf> Acesso em: 12 dez 2018

ALVES, M. T. G.; FRANCO, C. A pesquisa em eficácia no Brasil: evidências sobre o efeito das escolas e fatores associados à eficácia escolar. In: BROOKE, Nigel; SOARES, José Francisco (Ogs.). Pesquisa em eficácia escolar: origem e trajetória. Belo Horizonte: Editora UFMG, 2008.

ALVES, M. T. G.; XAVIER, F. P.. Construção de indicadores para descrever desigualdades de aprendizado na Prova Brasil. Estudos em Avaliação Educacional. São Paulo, v. 27, n. 66, p. 782-815, set/dez 2016.

ANDRADE, F. M. de; KOSLINSKI, M. C.; CENEVIDA, R. Fatores associados à rotatividade de diretores no município do Rio de Janeiro. Educação em Revista|Belo Horizonte|n.34|e182446|2018. Disponível em: $<$ http://www.scielo.br/pdf/edur/v34/1982-6621-edur-34-e182446.pdf > Acesso em: 25 dez 2018.

ARAÚJO, C. A. O que é Ciência da Informação? Inf. Inf., Londrina, v. 19, n. 1, p. $01 \quad-\quad 30, \quad$ jan/abr. 2014. Disponível em: <http://www.uel.br/revistas/uel/index.php/informacao/article/view/15958/14205> Acesso em: 30 abr 2018.

AUGUSTO, M. H.. Os últimos dez anos de governo em Minas Gerais: a política de resultados e o trabalho docente. Educação \& Sociedade, Campinas - SP, v. 34, n. 125, pp. 1269-1285, out /dez 2013.

Regulação educativa e trabalho docente em Minas Gerais: a obrigação de resultados. Educação e Pesquisa, São Paulo, v. 38, n. 03, p. 695-709, jul./set. 2012. Disponível em: $<$ http://www.scielo.br/pdf/ep/v38n3/11.pdf $>$ Acesso em: 26 dez 2018.

AZZI, R. G.. Mídias, transformações sociais e contribuições da teoria social cognitiva. Psico, Porto Alegre, PUCRS, v. 41, n. 2, pp. 252-258, abr./jun. 2010. Disponível em: $\quad$ http://teoriasocialcognitiva.net.br/wpcontent/uploads/2014/09/AZZI_2010b.pdf> Acesso em: 11 jan 2019

BABBIE, E.. Métodos de Pesquisas de Survey. Belo Horizonte: Editora UFMG, 2001.

BALDUTI, C. F.; SANTOS, Gilmar José dos (orientador). Possibilidades de aperfeiçoamento do Sistema Mineiro de Administração Escolar (SIMADE). Juiz de Fora, 2017. 164 p. Dissertação de mestrado profissional - Programa de Pós- 
Graduação em Gestão e Avaliação da Educação Pública - Faculdade de Educação/CAEd. Universidade Federal de Juiz de Fora. Disponível em: $<$ http://www.mestrado.caedufjf.net/possibilidades-de-aperfeicoamento-dosistema-mineiro-de-administracao-escolar-simade/> Acesso em: 10 fev 2018.

BANDURA, A. Self-efficacy, the exercise of control. New York: Freeman and Company, 1997.

BANDURA, A. Guide for constructing self-efficacy scales. In: PAJARES, F.; URDAN, T. Selfefficay beliefs ofadolescentes. USA: Information Age Publishing, 2006. p. 307-337.

BANDURA, A. Much ado over a faulty conception of perceived self-efficacy grounded in faulty experimentation. Journal of social and clinical psychology, v. 26, n. 6, p. 641-658, 2007. Disponível em: <https://www.uky.edu/ eushe2/Bandura/Bandura2007JSCP.pdf > Acesso em: 01 $\operatorname{dez} 2018$.

BANDURA, A., \& LOCKE, E. (2003). Negative self-efficacy and goal effects revisited. Journal of Applied Psychology, 88, 87-99. Disponível em: $<$ https://www.researchgate.net/publication/10822958 Negative SelfEfficacy_and_Goal_Effects_Revisited> Acesso em: 27 nov 2018.

BASNIAK, M I; SOARES, M T C. O ProInfo e a disseminação da Tecnologia Educacional no Brasil. Educação Unisinos, vol. 20, núm. 2, 2016. Disponível em: $<$ https://www.redalyc.org/jatsRepo/4496/449646791007/html/index.html > Acesso em: 05 nov 2018

BARROSO, J. O Estado, a educação e a regulação das políticas públicas. Educ. Soc., Campinas, vol. 26, n. 92, p. 725-751, Especial - Out. 2005.

O Estado e a educação: a regulação internacional, a regulação nacional e a regulação local. In: João Barroso, org. A regulação das políticas públicas de educação: espaços, dinâmicas e actores. Lisboa: EDUCA e Unidade de I\&D em Ciências da Educação, pp. 41-70. Disponível em: <http://hdl.handle.net/10451/5761> Acesso em: 11/01/2019

BARROSO, A. Instrumentos de pesquisa científica qualitativa: vantagens, limitações, fidedignidade e confiabilidade. EFDeportes.com, Revista Digital. Buenos Aires, Año 17, $N^{\circ}$ 172, Septiembre de 2012. Disponível em: $<$ http://www.efdeportes.com/efd172/instrumentos-de-pesquisa-cientificaqualitativa.htm> Acesso em: 05 jun 2018.

BAUER, A.; ALAVARSE, O. M.; OLIVEIRA, R. P.Avaliações em larga escala: uma sistematização do debate. Educ. Pesquisa, São Paulo, v. 41, n. especial, p. 1367-1382, dez., 2015 Disponível em: http://www.scielo.br/scielo.php?script=sci arttext\&pid=S151797022015001001367\&lng=pt\&tlng=pt> Acesso em: 29 abr. 2018 
BELLONI, M. L. Educação a Distância. Campinas, SP: Autores Associados, 2003.

BIO, B. F. Sistemas de Informação: um enfoque gerencial. São Paulo: Atlas, 1988.

BLAU, Ina; PRESSER, Ofer. e-Leadership of school principals: Increasing school effectiveness by a school data management system. British Journal of Educational Technology. 04 July 2013Disponível em: <https://onlinelibrary.wiley.com/doi/abs/10.1111/bjet.12088> Acesso em: 01 jul. 2018

BONAMINO, A. M. C. de. Características da gestão escolar promotoras de sucesso. Coleção Gestão do Currículo e Gestão e Liderança - Volume III Gestão do Currículo e Gestão e Liderança - 2012 - pp. 117-132.

BONAMINO, A.M. C. de et al. Os efeitos das diferentes formas de capital no desempenho escolar: um estudo à luz de Bourdieu e de Coleman. Revista Brasileira de Educação, Rio de Janeiro, v. 15, n. 45, pp. 487-594, set./dez. 2010.

BONAMINO, A. M. C.; SOUSA, S. Z. Três gerações de avaliação da educação básica no Brasil: interfaces com o currículo da/na escola. Educação e Pesquisa, São Paulo, v. 38, n. 2, pp. 373-388, abr./jun. 2012.

BRASIL. LDB - Lei de Diretrizes e Bases da Educação Nacional no 9.394/96. Brasília: 1996.

BRASIL. Constituição Federal. Brasília, 1988. Versão atualizada disponível em: http://www.planalto.gov.br. Acesso em: 12 junho de 2018

BRASIL. Plano Diretor Plano Diretor da Reforma da Reforma do Aparelho do Estado. Presidência da República. Brasília, 1995 (Seções 1 a 5).

Ministério da Educação (MEC). Programa Nacional de Informática na Educação - Proinfo. Portaria $n^{0}$ 522, de 09 de abril de 1997. Diário Oficial da União, Brasília, DF, 11 abr. 1997. Seção 1, p. 7.189. Disponível em: $<$ http://portal.mec.gov.br/index.php?option=com content $\& v i e w=a r t i c l e \& i d=236$ \&Itemid=471> Acesso em: 16 maio de 2016.

Decreto 6.300, de 12 de dezembro de 2007. Dispõe sobre o Programa Nacional de Tecnologia Educacional - Proinfo. Disponível em: $<$ https://planalto.gov.br/ccivil_03/_atos2007-2010/2007/decreto/d6300.htm> Acesso em: 16 ago 2012.

FNDE. Programa Banda Larga nas Escolas (PBLE). Decreto 6424. Altera que altera o Plano Geral de Metas para a Universalização do Serviço Telefônico Fixo Comutado Prestado no Regime Público (PGMU). 2014. Disponível em: <http://www.fnde.gov.br/programas/programa-nacional-de- 
tecnologia-educacionalproinfo/proinfo-programa-banda-larga-nas-escolas-pble> Acesso em 10 nov 2016.

Cidades@.Minas Gerais. Disponível em: <http://cidades.ibge.gov.br/xtras/uf.php?lang=\&coduf=31\&search=minas-gerais $>$. Acesso em: 04 ago 2016.

INEP - IDEB. Disponível em: <http://portal.inep.gov.br/ideb> Acesso em: 01 jun. 2017.

INEP - Censo Escolar. 2016. Disponível em: <http://inep.gov.br/censoescolar> Acesso em: 17 maio. 2018

IBGE. 2017 - Minas Gerais. Disponível em: 〈https://www.educacao.mg.gov.br/images/documentos/Educacenso\%202016.pdf $>$

Acesso em: 25 jan. 2018.

Lei $\mathrm{N}^{\circ}$ 12.249, de 11 de junho de 2010. Cria o Programa Um Computador por Aluno - PROUCA e institui o Regime Especial de Aquisição de Computadores para Uso Educacional - RECOMPE. Diário Oficial da União. 14 jun. Disponível em: <http://www.planalto.gov.br/ccivil_03/_ato20072010/2010/lei/112249.htm> Acesso em: 27 jun. 2018.

, Minas Gerais. Censo Escolar. Disponível em <https://www.educacao.mg.gov.br/images/documentos/Educacenso\%202016.pdf $>$ Acesso em: 25 jan. 2018.

Nota Técnica $\mathrm{N}^{\mathrm{o}}$ 040/2014. Indicador para mensurar a complexidade da gestão nas escolas a partir dos dados do Censo Escolar da Educação Básica. Disponível em: $<$ http://download.inep.gov.br/informacoes estatisticas/indicadores educacionais/ 2014/escola_complexidade_gestao/nota_tecnica_indicador_escola_complexidade gestao.pdf $>$. Acesso em: $17 \mathrm{dez} .2017$.

Ranking IDHM Municípios 2010. Disponível em: <http://www.br.undp.org/content/brazil/pt/home/idh0/rankings/idhm-municipios2010.html > Acesso em: 05 maio 2018.

b . Aberto prazo para retificação de dados do censo escolar. 2016. Disponível em: <http://portal.mec.gov.br/component/tags/tag/32125> Acesso em: 16 abr. 2018.

d. Censo Escolar da Educação Básica 2016: notas estatísticas. BrasíliaDF | Fevereiro de 2017. Disponível em:< http://download.inep.gov.br/educacao basica/censo escolar/notas estatisticas/201 
7/notas_estatisticas_censo_escolar_da_educacao_basica_2016.pdf $>$ Acesso em: 07 maio 2018.

BROOKE, N.; SOARES, J. F. (Orgs.). Pesquisa em eficácia escolar: origem e trajetórias. Belo Horizonte: Editora UFMG, 2008.

BROOKE, N.; CUNHA, M. A. de A. A avaliação externa como instrumento da gestão educacional nos estados. Estudos \& pesquisas educacionais, São Paulo: Fundação Victor Civita, 2011.

BROOKE, N. Eficácia escolar. In:OLIVEIRA, D.A.; DUARTE, A.M.C.; VIEIRA, L.M.F. DICIONÁRIO: trabalho, profissão e condição docente. Belo Horizonte: UFMG/Faculdade de Educação, 2010. CDROM

CAEd. Revista Simade. Juiz de Fora - MG: Centro de Políticas Públicas e Avaliação da Educação, 2008.

. O que fazemos. 2015b. Disponível em: <http://www.gestao.caedufjf.net/o-que-fazemos/>. Acesso em: 03 out. 2015.

Portal do Sistema Mineiro de Administração Escolar. Disponível em: $\langle$ http://www.gestao.caedufjf.net/sistemas-de-gestao/simade> Acesso em: $19 \mathrm{dez}$. 2014.

- Sistema Mineiro de Administração Escolar. Disponível em: http://simadeweb.educacao.mg.gov.br/SimadeWeb/inicio.faces Acessado em: 20/10/2019

CALDERÓN, A. I. Usos e apropriações das avaliações em larga escala: tensões e desafios. In: Séries Diálogos e Proposições: planos de ação para a Rede Estadual de Ensino de Minas Gerais. Orgs: QUIOSSA, Amanda Sangy; BERTOLOTTI, Diovana Paula de Jesus; NEUBERT, LUIZ Flávio; CUNHA, Priscila Campos. ${ }^{\text {a }}$ ed. Juiz de fora: Projeto CAEd-FADEPE/JF, 2017. Volume II. p.31-45.

CAMPOS, G. B de; CAMPOS, F. C. A. Qualidade de software educacional. In: ROCHA, Ana Regina i; MALDONADO, José Carlos; WEBER, Kival Chaves. Qualidade de Software: teoria e prática. São Paulo: Prentice Hall, 2001.

CARLOMAGNO, M. C.; ROCHA, L. C. da. Como criar e classificar categorias para fazer análise de conteúdo: uma questão metodológica. Revista Eletrônica de Ciência Política, vol. 7, n. 1, 2016. Disponível em: <https://revistas.ufpr.br/politica/article/view/45771/28756> Acesso em: 27 nov 2018.

CARVALHO, E. J. Reestruturação produtiva, reforma administrativa do estado e gestão da educação. Educ. Soc., Campinas, vol. 30, n. 109, p. 1139-1166, set./dez. 2009.

CAVALCANTE, K. de S.; SOUSA, M. S. de; OLIVEIRA, L.R. P. de; OLIVEIRA, I. S. M. de. Análise de Softwares de Gestão Escolar Open Source para uma Escola Privada do Ensino Básico. Nuevas Ideas en Informática Educativa, v. 12, 
2016. p. 157 - 166. Santiago de Chile. Disponível em: <http://www.tise.cl/volumen12/TISE2016/157-166.pdf> Acesso em: 12 maio 2018.

CERDEIRA, D. G. da PRADO, A. P. do; ROSISTOLATO, R. P. da ; TAVARES, M. de O.; COSTA, M. da. Conhecimento e uso de indicadores educacionais no município do Rio de Janeiro. Est. Aval. Educ., São Paulo, v. 28, n. 69, p. 926968, set./dez. 2017.

CONDÉ, E. S. Políticas: aprendendo a leitura dos sinais. Coleção Gestão e Avaliação da Educação Pública - Volume I - Políticas Educacionais e Avaliação de Programas. Juiz de Fora - MG: FADEPE, 2011.

CORREA, F.; ZIVIANI, F. A gestão do conhecimento aplicada ao setor de Tecnologia da Informação. Inf. \& Soc.:Est., João Pessoa, v.25, n.1, p. 101-122, jan./abr. 2015.

COSTA, J. A.; CASTANHEIRA, P. A liderança na gestão das escolas: contributos de análise organizacional. Revista Brasileira de Política e Administração da Educação (RBPAE), Goiânia, v. 31, n. 1, pp. 13-44, jan./abr. 2015.

COSTA JÚNIOR, A. A. da; SCHMITZ, H.; COSTA NETO, A.. Adaptação, melhoramento e gerenciamento de um software de gestão educacional e sua influência na gestão democrático-participativa. VI Colóquio Internacional "Educação e Contemporaneidade". São Cristovão -SE/Brasil. 20 a 22 de setembro de 2012.2 Disponível em: $\langle$ https://ri.ufs.br/bitstream/riufs/687/1/SoftwareGestaoComputacao.pdf $>$ Acesso em: 23 out 2018.

COSTA, L. F. da; RAMALHO, F. A. A usabilidade nos estudos de uso da informação: em cena usuários e sistemas interativos de informação. Perspectiva em Ciência da Informação, v. 15, n. 1, p. 92 -117, jan./abr.2010 Disponível em: $<$ http://www.scielo.br/pdf/pci/v15n1/06.pdf: Acesso em: 20 jun 2018.

CUNHA, L. A. A escolarização Desigual. In: Educação e Desenvolvimento Social no Brasil p. 112 -150. Rio de Janeiro. 1975.

CUNHA, V. A. F. (2013). Impacto da aplicação Place na gestão administrativa das Escolas da Região Autónoma da Madeira: estudo de caso. Dissertação para obtenção do grau de Mestre em Administração Pública - Especialização em Administração da Educação. Lisboa. Disponível em: <https://www.repository.utl.pt/bitstream/10400.5/6553/1/Dissertacao_VascoCunh a_Place_2013_ARDITI_29012014.pdf> Acesso em: 05 fev. 2017.

CRUZ, L. F. R. Avaliação externa e qualidade de ensino: apropriações e usos dos dados em escolas públicas municipais de Macaé/RJ. 2014. 176f. Tese (Doutorado em Educação) - Faculdade de Educação, Pontifícia Universidade Católica do Rio de Janeiro, Rio de Janeiro, 2014. 
DATNOW, A.; SCHILDKAMP, K. Uso de datos en la promoción de la mejora. Revista Eletrônica de Educação, v. 13, n. 1, p. 66-86, jan./abr. 2019. Disponível em: $\quad$ http://www.reveduc.ufscar.br/index.php/reveduc/article/view/3076/786> Acesso em: 20 jan 2019.

DAVIS, G. B.; OLSON, M. H. Sistemas de Información Gerencial. Bogotá: McGraw-Hill. 1987.

DEMIR, K.. School management information systems in primary schools. The Turkish Online Journal of Educational Technology - TOJET April 2006 ISSN: 1303-6521 volume 5 Issue 2 Article 6. Disponível em: <https://files.eric.ed.gov/fulltext/EJ1102477.pdf> Acesso em: 21 mar. 2018.

DÖS, I.; SAVAS, A. C. Elementary School Administrators and Their Roles in the Context of Effective Schools. Disponível em: $\langle$ https://journals.sagepub.com/doi/pdf/10.1177/2158244014567400> Acesso em: 19 nov 2018.

DRABACH, N.P.; SOUZA, A. R. de. Leituras sobre a gestão democrática e o "gerencialismo" na/da educação no Brasil. Revista Pedagógica, Chapecó - SC, v.16, n.33, pp. 221-248, jul./dez. 2014. Disponível em: $<$ https://bell.unochapeco.edu.br/revistas/index.php/pedagogica/article/view/2851/ 1655> Acesso em: 18 maio 2016.

DUARTE, A.; AUGUSTO, M. H.; JORGE, T.. Gestão escolar e o trabalho dos diretores em Minas Gerais. Poiésis, Tubarão. v.10, n.17, p.199 -214, Jan/Jun 2016 Disponível em: $<$ http://www.portaldeperiodicos.unisul.br/index.php/Poiesis/index $>$ Acesdo em: 01 dez. 2016.

ESQUINSANI, R. S. S.; SILVEIRA, C. L. A. da. Agendas da educação básica: gestão escolar e qualidade da educação. RBPAE - v. 31, n. 1, p. 145 - 157 jan./abr. 2015.

FERREIRA, D. D.; LOTTA, G. S. Burocratas: atores entre as fronteiras do Estado e da sociedade. $40^{\circ}$ Encontro Anual da Anpocs. ST13 Entre as ruas e os gabinetes: institucionalização e contestação nos movimentos sociais. Disponível em: <https://www.anpocs.com/index.php/papers-40-encontro/st-10/st13-7/10267burocratas-atores-entre-as-fronteiras-do-estado-e-da-sociedade/file > Acesso em: 05 jul. 2018.

FIGUEIREDO FILHO, D. B.; SILVA JÚNIOR, J. A. da. Visão além do alcance: uma introdução à análise fatorial. Opinião Pública, Campinas, vol. 16, $\mathrm{n}^{\circ} 1$, Junho, 2010, p. 160-185. Disponível em: <http://www.scielo.br/pdf/op/v16n1/a07v16n1.pdf> Acesso em: 12 jan 2019

FILHO, J. C. dos S.; GAMBOA, S. S. Pesquisa Educacional: quantidadequalidade. $7^{\text {a }}$ Ed São Paulo, Cortez, 2009. 
FILHO, M. M. Isoni; BELLINI, C. G. Porto. Relação entre Autoeficácia e Ansiedade Computacional: Uma Revisão Sistemática da Literatura. EnANPAD. XXXVIII Encontro da ANPAD. Rio de Janeiro/RJ - 13 a 17 de setembro de 2014. Disponível em: <http://www.anpad.org.br/admin/pdf/2014 EnANPAD ADI2045.pdf> Acesso em: 07 jun. 2008.

FISHER, Y.. The sense of self-efficacy of aspiring principals: exploration in a dynamic concept. Social Psychology of Education: An International Journal, v. 14, n. 1, p. 93-117, mar. 2011. Disponível em: https://link.springer.com/article/10.1007/s11218-010-9136-9 Acesso em: $15 \mathrm{dez}$ 2018

FONSECA, J. F. da. SANTOS, G. J. dos (orientador). Gestão Escolar em Rede: estudo de caso de proposta de melhorias do Sistema Mineiro de Administração Escolar na Superintendência Regional de Ensino de Ouro Preto. Juiz de Fora, 2014. 144 p. Dissertação de mestrado profissional - Programa de Pós Graduação em Gestão e Avaliação da Educação Pública - Faculdade de Educação/CAEd. Universidade Federal de Juiz de Fora. Disponível em: $<$ http://www.mestrado.caedufjf.net/gestao-escolar-em-rede-estudo-de-caso-eproposta-de-melhorias-do-sistema-mineiro-de-administracao-escolar-nasuperintendencia-regional-de-ensino-de-ouro-preto> Acesso em: 05 abr 2018.

FONTANIVE, N. S. A divulgação dos resultados das avaliações dos sistemas escolares: limitações e perspectivas. Ensaio: Avaliação e Políticas Públicas em Educação, Rio de Janeiro, v.21, n.78, p.83-100, jan/mar 2013.

FORMIGA, M. das G. F.; BARBOSA, J. G. O administrativo e o pedagógico na gestão escolar: um olhar sobre sua relação. 2007. Disponível em: <http://www.anpae.org.br/congressos_antigos/simposio2007/284.pdf > Acesso em: 10 jul 2018.

FRANCO, C.; ORTIGÃO, I.; ALBERNAZ, A.; BONAMINO, A.; AGUIAR, G.; ALVES, F.; SATYRO, N. Qualidade e equidade em educação: reconsiderando o significado de "fatores intra-escolares". Ensaio: aval. pol. públ. Educ., Rio de Janeiro, v.15, n.55, p. 277-298, abr./jun. 2007.

FRANCO, K. O.; CALDERÓN, A. I. O SIMAVE à luz das três gerações de avaliação da educação básica. Est. Aval. Educ., São Paulo, v. 28, n. 67, p. 132159, jan./abr. 2017. Disponível em: <http://publicacoes.fcc.org.br/ojs/index.php/eae/article/viewFile/3826/3345>

Acesso em: $22 \mathrm{dez} 2018$.

FREIRE, T. H. F. BASTOS JÚNIOR, M. S. F. Revista Expressão Católica 2013 jul./dez.; 2(2): A Importância dos sistemas de informação na gestão de escolas privadas no município de Quixadá. Revista Expressão Católica 2013 jul./dez.; 2(2): $\quad 67 \quad-\quad 82 . \quad$ Disponível em: <http://publicacoesacademicas.fcrs.edu.br/index.php/rec/article/view/1323/1086> Acesso em: 08 maio 2018. 
FREITAS, L. C. de. Políticas de responsabilização: entre a falta de evidência e a ética. Cadernos de Pesquisa v.43 n.148 p.348-365 jan./abr. 2013. Disponível em: http://www.scielo.br/pdf/cp/v43n148/18.pdf Acesso em: 05/05/2015

GIL, A. C. Métodos e técnicas de pesquisa social. 5. ed. São Paulo: Atlas, 1999.

Como elaborar projetos de pesquisa. 4. ed. São Paulo: Atlas, 2002.

GUERREIRO-CASANOVA, D. C. Eficácia coletiva escolar: contribuições das crenças de eficácia de docentes e gestores escolares. Psicologia: Ensino \& Formação, 2014.

GUERREIRO-CASANOVA, D. C.; AZZI， R. G. Percepções de Gestores Escolares sobre Autoeficácia e IDESP. 2012. Disponível em: $<$ http://www.anpae.org.br/iberoamericano2012/Trabalhos/DanielaCoutoGuerreiro int GT8.pdf>. Acesso em: 31 jul. 2016.

GUERREIRO-CASANOVA, D. C.; RUSSO, M. H.. Crenças de autoeficácia de gestores escolares: variáveis relacionadas. Psic. da Ed., São Paulo, 42, $1^{\circ} \mathrm{sem}$. de 2016, pp. 1-11. Disponível em: 〈http://pepsic.bvsalud.org/pdf/psie/n42/n42a01.pdf> Acesso em: 06 nov. 2016.

GUERREIRO-CASANOVA, D. C.; AZZI， R. G. Análise sobre variáveis explicativas da autoeficácia docente. Educar em Revista, Curitiba, Brasil, n. 58, p. 237-252, out./dez. 2015. Disponível em: <http://www.scielo.br/pdf/er/n58/19840411-er-58-00237.pdf> Acesso em: 05 jul. 2016.

GUERREIRO-CASANOVA, D. C.; AZZI, R. G (orientador). Crenças de eficácia de gestores escolares e de docentes no ensino médio paulista. Campinas, 2013. 199 p. Tese de doutorado - Departamento de Educação, Universidade Estadual de Campinas. Disponível em: $<$ http://taurus.unicamp.br/bitstream/REPOSIP/250823/1/Casanova DanielaCouto Guerreiro_D.pdf> Acesso em: 06 jun. 2016.

GUERREIRO-CASANOVA, D. C.; AZZI, R. G Lidar com as adversidades do contexto escolar: discussão a partir das crenças de eficácia de gestores escolares. Disponível em: <http://www.anpae.org.br/IBERO_AMERICANO_IV/GT4/GT4_Comunicacao/D anielaGuerreiroCasanova GT4 integral.pdf $>$ Acesso em: $30 \mathrm{dez} 2018$.

GUERREIRO-CASANOVA, D. C.; AZZI，R. G. Autoeficácia de gestores escolares: algumas percepções. Conferência IX Simpósio do laboratório de gestão educacional, volume: governança democrática na educação: sistema, rede e escola. Abril de 2013. Disponível em: <https://www.researchgate.net/publication/246044536_AUTOEFICACIA_DE_G ESTORES ESCOLARES ALGUMAS PERCEPCOES> Acesso em: 06 jan 2019. 
GUIMARÃES, V.da F.; ABBAD, G. da S.. Autoeficácia no uso do computador em situações de aprendizagem: uma análise da literatura internacional. Psicol., Organ. Trab., abr-jun 2015, vol. 15 num. 2 Disponível em: <http://pepsic.bvsalud.org/pdf/rpot/v15n2/v15n2a07.pdf> Acesso em: 01 jul 2018.

GOMES, N da S. Qualidade de Software - uma necessidade. 2013. Disponível em: 〈http://www.unisalesiano.edu.br/salaEstudo/materiais/pd6952/materiall.pdf > Acesso em: 15 mar. 2018.

GOMES, M. A.; DUMONT, L. M. M. Possíveis relações entre o uso de fontes de informação e a competência em informação. TransInformação, Campinas, 27(2):133-143, maio/ago., 2015 Disponível em: $\langle$ http://www.scielo.br/pdf/tinf/v27n2/0103-3786-tinf-27-02-00133.pdf > Acesso em: 08 fev. 2018.

GONZAGA, D. de A.; HANSEN, A. de O.. Sistema de gestão Nota 10: como a escolas tem se apropriado dos sistemas de informação? Revista Profissão Docente Uberaba, v. 16, n. 34, p. 72-90, Fev.-Jul., 2016. Disponível em: <http://www.revistas.uniube.br/index.php/rpd/article/viewFile/981/1271> Acesso em: 02 jul. $/ 2018$.

GUSMÃO, J. B. de. A construção da noção de qualidade da educação. Ensaio: aval. pol. públ. Educ., Rio de Janeiro, v. 21, n. 79, p. 299-322, abr./jun. 2013 Disponível em: http://www.scielo.br/pdf/ensaio/v21n79/07.pdf Acessado em: 22 jan 2019

HÖFLING, E. de M. Estado e Políticas (Públicas) Sociais. Cadernos Cedes, ano $\mathrm{XXI}, \mathrm{n}^{\mathrm{o}}$ 55, novembro/2001 - pág. 30 - 41. Disponível em: <http://www.scielo.br/pdf/ccedes/v21n55/5539> Acesso: 29 jun. 2018.

IAOCHITE, R. T. Crenças de Autoeficácia: considerações teóricas. In: Autoeficácia em contextos de saúde, educação e política. Orgs: IAOCHITE, Roberto Tadeu; AZZI, Roberta Gurgel. Porto Alegre: Letra 1, 2017. - (Coleção TSC em Debate; 1) 13 - 28.

I.AOCHITE, R. T.; COSTA FILHO, R. A. da; M.ATOS, M. da M.; SACHIMBOMBO, K. M. C. Autoeficácia no campo educacional: revisão das publicações em periódicos brasileiros. Psicologia Escolar e Educacional, SP. Volume 20, Número 1, Janeiro/Abril de 2016: 45-54. Disponível: <http://www.scielo.br/pdf/pee/v20n1/2175-3539-pee-20-01-00045.pdf> Acesso em: 30 dez 2018.

IAOCHITE, R. T.; COSTA FILHO, R. A. da. Crença de autoeficácia para prática de atividade física e variáveis de contexto de uma Escola Pública Paulista. Orgs: IAOCHITE, Roberto Tadeu; AZZI, Roberta Gurgel. Porto Alegre: Letra 1, 2017. - (Coleção TSC em Debate; 1) 95 - 110.

IRVING, E., \& Gan, M. Data systems in secondary schools: The state of play. Computers in New Zealand Schools, Vol.24, No. 2, pp.108-136, (2012). Disponível em: <https://www.otago.ac.nz/cdelt/otago063723.pdf> Acesso em: 21 maio 2018. 
ISO 9126. 2010. Norma. Disponível em: $<$ http://usabilideiros.com.br/index.php/qualidade-desoftware/ item/5-norma-iso9126>. Acesso em: 20 jun. 2016.

KORNELIS, M.; OCK, Y. S. Design of School Management Information System Based on the Indonesian National Education Standard. International Journal of Contents. 2014. Jun, 10(2): 67-73. Disponível em: http://www.kpubs.org/article/articleMain.kpubs?articleANo=E1CTBR_2014_v10 n2 67 Acesso em: 21 jan 2019.

LEAL, I. O. J.; NOVAES, I. L. O diretor de escola pública municipal frente às atribuições da gestão administrativa. Regae: Rev. Gest. Aval. Educ. Santa Maria v. 7 n. 14 Jan./abr. 2018 p. 63-77. Disponível em: $<$ https://periodicos.ufsm.br/regae/article/viewFile/30020/pdf $>$ Acesso em: 08 jul 2018.

LEITE, Y. U. F.; LIMA, V. M. M. Formação continuada de diretores escolares: uma experiência fundamentada na pesquisa ação colaborativa. RBPAE, n. 31, p. 45-64, jan 2015.

LEITHWOOD, K. ¿Cómo liderar nuestras escuelas? Aportes desde la investigación. Santiago: Salesianos Impresores, 2009.

LESSA, P. B.; TEIXEIRA, B. de B.. Diretores de escola em Minas Gerais querem currículo unificado? Cadernos CENPEC | São Paulo | v.3 | n.2 | p.99-119 | jun. $2013 . \quad$ Disponível em: <http://cadernos.cenpec.org.br/cadernos/index.php/cadernos/article/view/262/260 $>$ Acesso em: 15 jun 2018.

LIMA, L. C. A escola como organização educativa: uma abordagem sociológica. 4 ed. São Paulo: Cortez, 2011.

LIMA, L; D'ASCENZI, L. Implementação de políticas públicas: perspectivas analíticas. Revista de Sociologia e Política. v. 21, n. 48, p. 101-110, dez. 2013.

LIMA, T. H. de; MARTINS, M. R.; SANTOS, A. A. A. dos; NUNES, M. F. O. Autoeficácia para Atividades Ocupacionais: Uma Comparação entre as Gerações X e Y. Revista Brasileira de Orientação Profissional jul.-dez. 2016, Vol. 17, No. 2, 201-210 . Disponível em: 〈http://pepsic.bvsalud.org/pdf/rbop/v17n2/08.pdf> Acesso em: $02 \mathrm{dez} 2018$.

LINHARES, B. de F.; ALVES, D. S. Metodologia de ensino em pesquisa social quantitativa. Pelotas [14]: 23 - 39; janeiro-junho 2014. Disponível em: $<$ https://periodicos.ufpel.edu.br/ojs2/index.php/pensamentoplural/article/viewFile/ 3782/3412> Acesso em: 04 jan 2019.

LOTTA, G. S.. Agentes de implementação: uma forma de análise de políticas públicas. Cadernos Gestão Pública e Cidadania. São Paulo, v.19, n.65, jul./dez. 2014. 
Burocracia e implementação de políticas de saúde: os agentes comunitários na estratégia Saúde da Família. Rio de Janeiro: Editora Fiocruz, 2015.

LÜCK, Heloisa. Gestão escolar e formação de gestores. Em Aberto, v. 17, n.72, p. 1-195, fev./jun. 2000.

Ação integrada: administração, supervisão e orientação educacional. 29. ed. Petrópolis: Vozes, 2013.

MACHADO, M. A. de M.. Desafios a serem enfrentados na capacitação de gestores escolares. Em Aberto, Brasília, v. 17, n. 72, p. 97 -112, fev./jun., 2000.

MANDINACH, E. B.; GUMMER, E. S. A Systemic View of Implementing Data Literacy in Educator Preparation. 2012. Disponível em: $\langle$ http://edr.sagepub.com/content/42/1/30 $>$. Acesso em: 18 nov. 2015.

MARCONI, M. de A..; LAKATOS, Eva Maria. Técnicas de pesquisa. São Paulo: Atlas, 1999.

Atlas 2003.

Fundamentos da Metodologia Científica. - 5. ed. - São Paulo :

MCCORMICK, M. J. Self-efficacy and leadership effectiveness: applying social cognitive theory to leadership. The Journal of Leadership studies, v. 8, n. 1, p. 22-33, 2001.

MARKS, H. M.; PRINTY, S. M. Principal leadership and school performance: An integration of transformational and instructional leadership. Educational Administration Quarterly, New York-NY, v. 39, n. 3, pp. 370-397, ago. 2003.

MARSH, J.; MCCOMBS, J.; MARTORELL, F.. How Instructional Coaches Support Data-Driven Decision Making: Policy Implementation and Effects in Florida Middle Schools. Educational Policy, Boulder - CO, v. 24, n. 6, pp. 872907, nov. 2010.

MARTINS, M. A. dos A. L. SANTOS, G. J. dos (orientador). Estudo comparativo da utilização do Sistema Mineiro de Administração Escolar (SIMADE) por duas escolas estaduais da SRE Coronel Fabriciano. Juiz de Fora, 2014. 122 p. Dissertação de mestrado profissional - Programa de Pós Graduação em Gestão e Avaliação da Educação Pública - Faculdade de Educação/CAEd. Universidade Federal de Juiz de Fora. Disponível em: <http://www.mestrado.caedufjf.net/estudocomparativo-da-utilizacao-do-sistema-mineiro-de-administracao-escolar-simadepor-duas-escolas-estaduais-da-sre-coronel-fabriciano/> Acesso em: 10 fev. 2018.

MARTINS, R. X.; FLORES, V. de F. A implementação do Programa Nacional de Tecnologia Educacional (Proinfo): revelações de pesquisas realizadas no Brasil entre 2007 e 2011. Revista Brasileira Estudos Pedagógicos. (Online). Brasília, v. 96, n.242. p. 112-128, jan./abr. 2015. Disponível em: 
〈http://www.scielo.br/pdf/rbeped/v96n242/2176-6681-rbeped-96-242-00112.pdf > Acesso em: 16 jun. 2018

MASSA, H. C. O. D.; DAMIAN, I. P. M.; VALENTIM, M. L. P. Competência em informação no apoio à Gestão do Conhecimento. Inf. \& Soc.:Est., João Pessoa, v.28, n.1, p. 257-267, jan./abr. 2018. Disponível: <http://www.periodicos.ufpb.br/ojs2/index.php/ies/article/view/32569/pdf> Acesso em: 30 maio 2018.

MEDEIROS, M. A.; CYBIS, W. de A.. Método de avaliação de usabilidade de software a partir da satisfação de usuários e da aplicação de quesitos da norma ISO 9241. 2000. Disponível em: <http://www.lbd.dcc.ufmg.br/colecoes/ihc/2000/0002.pdf > Acesso em: 16 jun 2018.

MEJIA, J.; URIBE, G. Extracción del Conocimiento tácito como base para el establecimiento de mejora de procesos de software en las Organizaciones de desarrollo de Software. RISTI, N. ${ }^{\circ}$ E3, 03/2015 Disponível em:< http://www.scielo.mec.pt/pdf/rist/nspe3/nspe3a03.pdf> Acesso em: 28 abr. 2018.

MENDONÇA, E. F.. Estado Patrimonial e Gestão Democrática do Ensino Público no Brasil. Educação \& Sociedade, Campinas - SP, v. 22, n. 75, pp. 84108, ago. 2001.

MENDONÇA, T. C.; VARVAKIS, G. Análise do uso da informação para tomada de decisão gerencial em gestão de pessoas: estudo de caso em uma instituição bancária. Perspectivas em Ciência da Informação, v.23, n.1, p.104-119, jan./mar. 2018.

MINAS GERAIS. Resolução SEE $\mathbf{n}^{\circ}$. 1.180, de 28 agosto de 2008. Disponível em <https://www.educacao.mg.gov.br/index.php?option=com gmg\&controller=docu ment

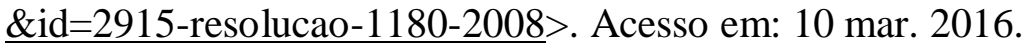

. Decreto $\mathrm{n}^{\mathrm{o}} 45.849$, de 27 de dezembro de 2011. Dispõe sobre a organização da Secretaria de Estado de Educação. Disponível em: $<$ http://magistra.educacao.mg.gov.br/images/stories/editais/decreto-no-45849-de27-dedezembro- de-2011.pdf $\rangle$. Acesso em: 9 ago. 2016.

Lei $n^{\circ} .17 .600$, de $1^{\circ}$ de julho de 2008. Disciplina o Acordo de Resultados e o Prêmio por Produtividade no âmbito do Poder Executivo e dá outras providências. Disponível em:

〈http://www.ipsm.mg.gov.br/arquivos/legislacoes/legislacao/leis/lei_17600.pdf $>$. Acesso em: 15 nov. 2015.

Edital SEE no 03/2015 - Certificação Ocupacional de Diretor de Escola Estadual. Disponível em: $<$ https://www.educacao.mg.gov.br/images/stories/certificacao_diretorEE/Edital\% 203\%20-\%20Certificao\%20Ocupacional.pdf> Acesso em: 24 jan. 2018. 
Decreto $\mathrm{N}^{\mathrm{o}} 44.871$, de 7 de agosto de 2008. Regulamenta a Certificação Ocupacional no âmbito do Poder Executivo. Disponível em: $<$ http://www.ipsm.mg.gov.br/arquivos/legislacoes/legislacao/decretos/decreto_44 871.pdf $>$ Aceso em: 31/01/2018.

Resolução SEE N. ${ }^{\circ}$ 1812, de 22 de março de 2011. Estabelece critérios e condições para a indicação de candidatos ao cargo de Diretor e à função de Vice-diretor de Escola Estadual de Minas Gerais e trata de outros dispositivos correlatos. Disponível em: <https://www.educacao.mg.gov.br/images/stories/noticias/resolucao-see-n.o1812.pdf $>$ Acesso em: 31 jan 2018.

Profissionais de Educação Básica do Estado Disponível em $<$ https://www.almg.gov.br/consulte/legislacao/completa/completa-novamin.html?tipo=Lei\&num $=15293 \&$ comp $=\& a n o=2004 \&$ texto $=$ original $>\quad$ Acesso em: 10 jun 2018.

Edital SEPLAG/see n'. 04/2014, de 24 de novembro de 2014. Concurso público para provimento de cargos das carreiras de assistente técnico de educação básica, especialista em educação básica e professor de educação básica do quadro de pessoal da secretaria de estado de educação. Disponível em: <https://www.educacao.mg.gov.br/images/documentos/Edital Ensino\%20Regular 24.11_Final_18\%20horas.pdf $>$ Acesso em: 10 jun 2018.

Escola $\quad$ Estadual.
<https://www.educacao.mg.gov.br/images/stories/certificacao_diretorEE/Edital\%
203\%20-\%20Certificao\%20Ocupacional.pdf> Aceso em: 24 jan 2018.

Decreto $\mathrm{N}^{\mathrm{o}}$ 44.871, de 7 de agosto de 2008. Regulamenta a Certificação Ocupacional no âmbito do Poder Executivo de Minas Gerais. Disponível em: <http://www.ipsm.mg.gov.br/arquivos/legislacoes/legislacao/decretos/decreto_44 871.pdf> Acesso em: 31 jan. 2018.

MINAYO, M. C. de S.; ASSIS, S. G. de; SOUZA, E. R. de. Avaliação por Triangulação de métodos: abordagem de programas sociais. Editora Fiocruz, 2005. 244 p.

MIRANDA, J. B.; MACHADO, M. C. da S. Gestão estratégica e participativa: uma alternativa para a rede pública municipal de ensino de Juiz de Fora. 2013. MG. Disponível em: <http://www.anpae.org.br/iberoamericano2012/Trabalhos/JoseliaBarbosaMiranda _res_int_GT8.pdf $>$. Acesso em: 26. nov. 2017.

MIRANDA, R. C. da R.. Conhecimento estratégico. Ci.Inf., Brasília, DF, v.45 n.3, p.119-135, set./dez. 2016 Disponível em: <http://revista.ibict.br/ciinf/article/view/4053/3571> Acesso em: 27 abr. 2018. 
MORAES, L. B. de; BARBOSA, R. R.. Cultura Informacional: uma proposta de modelo com foco organizacional. Inf. \& Soc.:Est., João Pessoa, v.25, n.3, p. 131146, set./dez. 2015.

MORAN, J. Gestão inovadora da escola com tecnologias. São Paulo, Avercamp, 2003. Páginas 151-164. Disponível em: http://www.eca.usp.br/prof/moran/site/textos/tecnologias_eduacacao/gestao.pdf Acesso em: 03 dez 2018.

NASCIMENTO, M. das G. C. de A.; REIS, R. F. dos. Formação docente: percepções de professores ingressantes na rede municipal de ensino do Rio de Janeiro. Educ. Pesqui., São Paulo, v. 43, n. 1, p. 49-64, jan./mar. 2017 Disponível em: <http://www.scielo.br/pdf/ep/v43n1/1517-9702-ep-43-1-0049.pdf> Acesso em: 29 jun 2018.

NEVES, S. P.; FARIA, L.. Auto-conceito e Autoe-eficácia: semelhanças, diferenças, inter-relação e influência no rendimento escolar. Revista da Faculdade de Ciências Humanas e Saúde. Porto: Edições Universidade Fernando Pessoa. ISSN 1646-0502.

NEUBAUER, R.; SILVEIRA, G. T. Gestão dos sistemas escolares: quais caminhos seguir? In: SCHWARTZMAN, Simon; COX, Cristián (Eds.). Políticas 67 Educacionais e Coesão Social: uma Agenda Latino-Americana. Rio de Janeiro: Campus, 2009.

NOGUEIRA, M. A.. A Sociologia da Educação do Final dos Anos 60/Início dos Anos 70: o nascimento do paradigma da reprodução. Em Aberto, Brasília, ano 9, n. 46, pp. 49-58, abr./jun. 1990.

A Sociologia da Educação do Imediato Pós-Guerra: orientações teórico-metodológicas. Caderno Ciência Social, Belo Horizonte, v. 4, n. 6, pp. 4366, dez. 1995.

NORAMBUENA, B. K.; ZEPEDA, V. V.. Minería de procesos de software: una revisión de experiencias de aplicación. RISTI, N. ${ }^{\circ}$ 21, 03/2017. Disponível em: <http://www.scielo.mec.pt/pdf/rist/n21/n21a05.pdf> Acesso: 24 abr 2018.

OGAWA, M. N.; FILIPAK, S. T. A formação do gestor escolar. In: SEMINÁRIO INTERNACIONAL SOBRE PROFISSIONALIZAÇÃO DOCENTE, 4., 2013, Curitiba. Anais... Curitiba: Pontifícia Universidade Católica do Paraná, 2013. p. 94108.

OLIVEIRA, A. C. P. de; PAES DE CARVALHO, C.. Gestão escolar, liderança do diretor e resultados educacionais no Brasil. Revista Brasileira de Educação v. 23 e230015. 2018. 18p. Disponível em: <http://www.scielo.br/pdf/rbedu/v23/1809449X-rbedu-23-e230015.pdf $>$ Acesso em: 08 jul 2018. 


\section{Gestão Escolar, Liderança do Diretor e Resultados}

Educacionais no Brasil. 2015. Disponível em:

$\leq 37$ reuniao.anped.org.br/wp-content/uploads/2015/02/Trabalho-GT14-4213.pdf $>$.

Acesso em: 29 set. 2015.

Política pública e gestão escolar: um estudo de caso no Rio de Janeiro. Jornal de Políticas Educacionais. $N^{\circ} 14$ | Julho - Dezembro de 2013 | pp 29 - 37. Disponível em: https://revistas.ufpr.br/jpe/article/download/31530/23326 Acesso em: 08 jul 2018.

OLIVEIRA, A. C. P. de; WALDHELM, A. P. S. Liderança do diretor, clima escolar e desempenho dos alunos: qual a relação? Ensaio: aval. pol. públ. Educ., Rio de Janeiro, v.24, n. 93, p. 824-844, out./dez. 2016 Disponível em: 〈http://www.scielo.br/pdf/ensaio/v24n93/1809-4465-ensaio-24-93-0824.pdf > Acesso em: 13 mar 2018.

OLIVEIRA, A. C. P. de; PAES DE CARVLAHO, C. (orintador). As relações entre Direção, Liderança e Clima Escolar em escolas municipais do Rio de Janeiro. Rio de Janeiro, 2015. 284 p. Tese de Doutorado - Departamento de Educação, Pontifícia Universidade Católica do Rio de Janeiro. Disponível em: <https://www.capes.gov.br/images/stories/download/pct/2016/MencoesHonrosas/Educacao-Ana-Cristina-Prado-Oliveira.PDF> Acesso em: 16 jan 2016.

OLIVEIRA, T. M. V. Amostragem não probabilística: adequação de situações para uso e limitações de amostras por conveniência, julgamento e quotas. FECAP. São Paulo, 2001. Disponível em: <http://www.fecap.br/adm_online/art23/tania2.htm>. Acesso em: 05 jun 2018.

OLIVEIRA, D. A. Nova Gestão Pública e governos democrático-populares: contradições entre a busca da eficiência e a ampliação do direito à educação. Educ. Soc., Campinas, v. 36, nº 132, p. 625-646, jul.-set., 2015. Disponível em: http://www.scielo.br/pdf/es/v36n132/1678-4626-es-36-132-00625.pdf Acesso em: 18 jan 2019.

PAES DE CARVALHO, C.; OLIVEIRA, A. C. P. de; LIMA, M. de F. M. de. Avaliações externas: tensões e desafios para a gestão escolar. Est. Aval. Educ., São Paulo, v. 25, n. 59, p. 50-76, set./dez. 2014. Disponível em: http://publicacoes.fcc.org.br/ojs/index.php/eae/article/view/2856/2849 Acesso em: 01 jul 2018.

PAES DE CARVALHO, C..; CANEDO, M. L. Estilos de Gestão, Cultura Organizacional e Qualidade de Ensino. Revista Educação e Cultura Contemporânea, v. 9, p. 78-98, 2012.

PARRA, V.; MATUS, G. (2018). Usos de datos y mejora escolar: Una aproximación a los sentidos y prácticas educativas subyacentes a los procesos de toma de decisiones. Calidad en la Educación, (45), 207-250. Disponível em: https://calidadenlaeducacion.cl/index.php/rce/article/view/25 Acesso em: $23 / 01 / 2019$ 
PENA, A. C.; SOARES, T. M.. Fatores de liderança escolar e sua relação com o desempenho: um estudo com diretores de escolas da rede pública de Minas Gerais/Brasil. Revista Iberoamericana sobre Calidad, Eficacia y Cambio em Educácion (REICE), Madrid, v. 12, n. 5, pp. 43-59, 2014.

PENA, A. C.; SOARES, T. M. (orientador). Um conceito para liderança escolar: estudo realizado com diretores de escolas da rede pública estadual de Minas Gerais. Juiz de Fora, 2013. 185 p. Tese de Doutorado - Departamento de Educação, Universidade Federal de Juiz de Fora. Disponível em: <http://www.ufjf.br/ppge/files/2013/07/Anderson-C\%C3\%B3rdova-Pena.pdf > Acesso em: 09 set 2015.

PIEDADE, J.; PEDRO, N. Tecnologias digitais na gestão escolar: práticas, proficiência e necessidades de formação dos diretores escolares em Portugal. CIED - Universidade do Minho Revista Portuguesa de Educação, 2014, 27(2), pp. 109133.

PIERCE, R.. A statistical literacy hierarchy for interpreting educational system data. Australian Journal of Education, Sydney, v. 58, n. 2, pp.195-217, 2014.

POLON, T. L. P. Perfis de liderança e característica relacionadas à gestão em escolas eficazes. Coleção gestão e avaliação da educação pública - v. 3. 2012.

POLON, T. L. P.; BONAMINO, Alicia Maria Catalano de. Identificação dos perfis de liderança e características relacionadas à gestão pedagógica em escolas eficazes. 2011. Disponível em:

<www.anpae.org.br/simposio2011/cdrom2011/PDFs/trabalhosCompletos/.../0521. pdf>. Acesso em: 21 fev. 2016.

PONTES, L. A. F. Medidas de eficácia escolar no contexto das políticas brasileiras de responsabilização educacional: o caso do Índice de Desenvolvimento da Educação Básica, o IDEB, em Minas Gerais. 2015. 243f. Tese (Doutorado em Educação) - Faculdade de Educação, Universidade Federal de Juiz de Fora, Juiz de Fora, 2015.

Indicadores Educacionais no Brasil e no Mundo: as diversas faces da educação. (Coleção Gestão e Avaliação da Educação Pública, v.1. Avaliação e Indicadores Educacionais e Políticas Públicas e Escola). Juiz de Fora - MG: FADEPE, 2012.

REYNOLDS, D.; TEDDLIE, C. Os processos da eficácia escolar. In: BROOKE, Nigel; SOARES, José Francisco (Orgs). Pesquisa em eficácia escolar: origem e trajetórias. Belo Horizonte: Editora UFMG, 2008. p. 297 - 334.

RIBEIRO, H. C. Diretor escolar: novos desafios, novas funções. 2012. Dissertação (Mestrado em Educação) - Universidade Federal de Juiz de Fora, Juiz de Fora, 2012.

RODRIGUES, C.; BLATTMANN, U. Gestão da informação e a importância do uso de fontes de informação para geração de conhecimento. Perspectivas em 
Ciência da Informação, v.19, n.3, p.4-29, jul./set. 2014 Disponível em: <http://www.scielo.br/pdf/pci/v19n3/a02v19n3.pdf> Acesso em: 21 jun 2018.

RODRIGUES, L. C.; BARRERA, S. D. Auto-eficácia e desempenho escolar em alunos do Ensino Fundamental. Psicologia em Pesquisa | UFJF | 1(02) | 41 - 53 | julho - dezembro de 2007. Disponível em: $\langle$ http://pepsic.bvsalud.org/pdf/psipesq/v1n2/v1n2a06.pdf> Acesso em: $02 \mathrm{dez}$ 2018.

ROQUE, A.; COSTA, J. A. A gestão da informação no contexto da gestão escolar. $2007 . \quad$ Disponível em: <www.revistas.udesc.br/index.php/linhas/article/view/1332> Acesso em 09 fev 2017.

RUSSO, M. H.; AZZI, R. G. . Crenças de eficácia de agentes escolares para a implementação de políticas educacionais. REVISTA DE ESTUDIOS E INVESTIGACIÓN EN PSICOLOGÍA Y EDUCACIÓN, 2017, Vol. Extr., No. 06, A6-066. Disponível em: 〈http://revistas.udc.es/index.php/reipe/article/view/reipe.2017.0.06.2248/pdf> Acesso em: 03 dez 2018.

RUSSO, G. A.. Autoeficácia e participação política. In: Autoeficácia em contexto de saúde, educação e política. Orgs: IAOCHITE, Roberto Tadeu. AZZI, Roberta Gurgel. Porto Alegre: Letral, 2017. - (Coleção TSC em Debate; 1) 142 p.

SALGADO, A. de F. C.; MELO, M. F. P. da C. e (orientador). Análise da gestão da informação no Sistema Mineiro de Administração Escolar (SIMADE) pelas superintendências regionais de ensino. Juiz de Fora, 2014. 108 p. Dissertação de mestrado profissional - Programa de Pós-Graduação em Gestão e Avaliação da Educação Pública - Faculdade de Educação/CAEd, Universidade Federal de Juiz de Fora. Disponível em: <http://www.mestrado.caedufjf.net/analise-da-gestao-dainformacao-no-sistema-mineiro-de-administracao-escolar-simade-pelassuperintendencias-regionais-de-ensino/> Acesso em: 16 jan. 2018.

SAMMONS, P. As características-chave das escolas eficazes. In: BROOKE, Nigel; SOARES, José Francisco (Orgs). Pesquisa em eficácia escolar: origem e trajetórias. Belo Horizonte: Editora UFMG, 2008.

SAMMONS, P; HILLMAN, J; MORTIMORE, P. Key Characteristics of Effective Schools. Key Characteristics of Effective Schools: A Review of School Effectiveness Research. London: Office for Standards in Education [OFSTED], 1955 .

SANCHÉZ, L.; R.,. M.; ORTIZ, D.; OLARTE, Fredy. El rol de la infraestructura tecnológica en relación con la brecha digital y la alfabetización digital en 100 instituciones educativas de colombia. CALIDAD EN LA EDUCACIÓN no 47, diciembre 2017. pp. 112-144. Disponível em: https://scielo.conicyt.cl/pdf/caledu/n47/0718-4565-caledu-47-00112.pdf Acesso em: 29 dez 2018. 
SANTANA, V. C. N.; FERREIRA, P. A.; LOURENÇO, C. D. da. Competências Gerenciais de Diretores de Escolas Estaduais de um município mineiro: um estudo comparativo entre a legislação e a percepção dos gestores escolares. IV Encontro de Gestão de Pessoas e Relações de Trabalho. Brasília/DF - 3 a 5 de novembro de 2013. Disponível em: http://www.anpad.org.br/admin/pdf/EnGPR138.pdf Acesso em: $18 \mathrm{dez} 2018$

SANTOS, T. S. dos. Do Artesanato Intelectual ao Contexto Virtual: ferramentas metodológicas para a pesquisa social. Sociologias, Porto Alegre, ano 11, n. 21, pp. 120- 156, jan./jun. 2009.

SANTOS, I. M. dos; PRADO, E. C. do. Formas de provimento do cargo de gestor escolar em Alagoas: tendências e configurações atuais na rede de educação pública municipal. Cadernos do Tempo Presente, n. 16, mai./jul. 2014, p. 40-49 Disponível em: <www.getempo.org> Acesso em: 04 fev. 2017.

SANTOS, H. M. dos; FLORES, D.. Novos rumos da preservação digital: das estratégias aos sistemas informatizados. Revista Biblios - Revista de Bibliotecología y Ciências de la Información. No 70 (2018). Disponível em: $\langle$ http://biblios.pitt.edu/ojs/index.php/biblios/article/view/326> Acesso: 24 abr 2018.

SANTOS, J. B. dos. Avaliação em larga escala na educação básica: uma discussão sobre o uso dos resultados para melhorar a educação. Revista Temas em Educação, João Pessoa, v.26, n. 1, p. 9-27, jan.-jun. 2017. Disponível em: http://www.periodicos.ufpb.br/index.php/rteo/article/viewFile/25931/20250

Acesso em: 03 jan 2019.

SETIAWAN, W.; NUGROHO, E. P.; MUNIR, M.; WIHARDI, Yaya. An Integrated High School Management System Architecture in Indonesia. Conference: International Seminar on Mathematics, Science, and Computer Science Education, At Bandung, Indonesia, Volume: 2, October 2015. Disponível em:

<https://www.researchgate.net/publication/290086630_An_Integrated_High_Scho ol_Management_System_Architecture_in_Indonesia> Acesso em: 21 mai 2018.

SHAH, M.. Impact of Management Information Systems (MIS) on School Administration: What the Literature Says. Procedia - Social and Behavioral Sciences 116 ( 2014 ) 2799 - 2804. Disponível em: https://www.sciencedirect.com/science/article/pii/S1877042814006764 Acesso em: 21 maio 2018.

SILVA, A. L. da. Breve discussão sobre o conceito de cidade média. Geoingá: Revista do Programa de Pós-Graduação em Geografia Maringá, v. 5, n. 1 , p. 5876, 2013. Disponível em: <http://eduem.uem.br/laboratorio/ojs/index.php/Geoinga/article/download/19983/ 11588> Acesso em: 09 jan. 2018 
SILVA, J. L. Ca.; GOMES, H. F. conceitos de informação na ciência da informação: percepções analíticas, proposições e categorizações. Inf. \& Soc.:Est., João Pessoa, v.25, n.1, p. 145-157, jan./abr. 2015.

SILVA, V. G. da; GIMENES, N. A. S; MARICONI, G. M. Uso da avaliação externa por equipes gestoras e profissionais docentes: um estudo em quatro redes de ensino público. São Paulo: FCC/SEP, 2013. Disponível em: <http://publicacoes.fcc.org.br/ojs/index.php/textosfcc/issue/view/292> Acesso em: 20 nov. 2015.

SILVA, V. G. da; PAES DE CARVALHO, C. Usos e efeitos das avaliações externas como objeto de pesquisa. Est. Aval. Educ., São Paulo, v. 25, n. 59, p. 12 21, set./dez. 2014.

SIMÃO, M. L.; NETTO, F. F.. Gestão escolar sob novos paradigmas: o papel do secretário escolar como agente ativo no processo de transformação das escolas. Ed.5 - 2008 UNICENTRO - Revista Eletrônica Lato Sensu. Disponível em: $<$ http://www.escoladegestao.pr.gov.br/arquivos/File/artigos/educacao/gestao_esco lar sob.pdf $>$ Acesso em: 21 jun. 2018.

SOARES, T. M.; TEIXEIRA, L. H. G. Efeito do Perfil do Diretor na Gestão Escolar sobre a proficiência do aluno. Estudos em Avaliação Educacional, São Paulo, v. 17, n. 34, pp.155-186, mai./ago. 2006.

SOARES, J. F.; ALVES, M. T. G. Escuelas de enseñanza fundamental Contextualización de los resultados. Revista Retratos de la Escuela, Brasília, v. 7, n. 12, p. 145-158, ene./jun. 2013. Disponível em: $\langle$ http://retratosdaescola.emnuvens.com.br/rde/article/viewFile/290/464〉 Acesso em: 27 jan. 2018.

SOARES, J. F. Melhora do desempenho cognitivo dos alunos do ensino fundamental. Cadernos de Pesquisa, v. 37, n. 130, p. 135-160, jan./abr. 2007. Disponível em: <http://www.scielo.br/pdf/cp/v37n130/07.pdf> Acesso em: 13 abr. 2018.

SOARES, J. F; ANDRADE, R. J. de. Nível socioeconômico, qualidade e eqüidade das escolas de Belo Horizonte. Ensaio: aval. pol. públ. Educ., Rio de Janeiro, v.14, n.50, p. 107-126, jan./mar. 2006. Disponível em: http://www.scielo.br/pdf/ensaio/v14n50/30410 Acesso em: $28 \mathrm{dez} 2018$

SOARES, S. C. A.; ASSIS, L; MACHADO, M. C. da. O equilíbrio entre asdimensões administrativa e pedagógica da gestão escolar como um desafio para diretores de escola:o caso da Superintendência Regional de Ensino de Pirapora/MG. p. 459-468. In: QUIOSSA, Amanda Sangy; BERTOLOTTI, Diovana Paula de Jesus; NEUBERT, Luiz Flávio; CUNHA, Priscila Campos. Diálogos e Proposições. Volume II: plano de ação para a rede estadual de ensino de Minas Gerais. $1^{\mathrm{a}}$ edição - Juiz de Fora - Projeto CAEd - FADEPE/JF - 2017. 
SOUZA, A. R. de; GOUVEIA, . Barbosa. Diretores de escolas públicas: aspectos do trabalho docente. Educar em Revista, Curitiba, Brasil, n. especial 1, p. 173-190, 2010..

SOUZA, C.. Estado do campo da pesquisa em políticas públicas no Brasil. Revista Brasileira de Ciências Sociais - RBCS, São Paulo, v. 18, n. 51, pp. 15-20, fev. 2003.

SUPOVITZ, J. A. Getting at student understanding - the key to teachers' use of test data. Teachers College Record, New York, v. 114, nov. 2012.

STARKEY, L.; EPPEL, E.. Digital data in New Zealand schools. SAGE JOURNALS. Disponível em: <http://journals.sagepub.com/doi/pdf/10.1177/1741143217745881> Acesso em: 20 maio 2015.

SPECK, R. A.; SCHREINER, M. A.; SOARES, J. P. R. dos S.; SILVA, L. B. da; LENHART, Gabriel Augusto. A gestão educacional com o i-Educar: análise da viabilidade de implantação no município de Palotina - Paraná. Semina: Ciências Sociais e Humanas, Londrina, v. 39, n. 1, p. 65-74, jan./jun. 2018. Disponível em: www.uel.br/revistas/uel/index.php/seminasoc/article/download/31090/23808 Acesso em: 15 jan 2019.

TAROUCO, L. M. R. Desafios da gestão e uso da TIC na escola. In: Formação de Gestores escolares para a educação básica: avanços, retrocessos e desafios frente aos 20 anos de normatização Da gestão democrática na LDBEN. Ogs: BATISTA, Neusa Chaves; FLORES, Maria Luiza Rodrigues. PortoAlegre: Evangraf: Escola de Gestores da Educação Básica 2016. p. 203 -226

TEIXEIRA, T. M. C.; VAlENTIM, Marta Lígia Pomim. Processo de busca e recuperação de informação em ambientes organizacionais: uma reflexão teórica sobre a subjetividade da informação. Perspectivas em Ciência da Informação, v.22, n.4, p.82-97, out./dez. 2017. Disponível em: <http://portaldeperiodicos.eci.ufmg.br/index.php/pci/article/view/2938/1983> Acesso em: 10 abr 2018.

TOMAZ, P. A.; SANTOS, G. J. dos (orientador). Possibilidades de usos das informações do Sistema Mineiro de Administração Escolar na gestão das escolas. Juiz de fora, 2015. 137 p. Dissertação de mestrado profissional - Programa de Pós Graduação em Gestão e Avaliação da Educação Pública - Faculdade de Educação/CAEd. Universidade Federal de Juiz de Fora. Disponível em: $<$ http://www.mestrado.caedufjf.net/possibilidades-de-uso-das-informacoes-dosistema-mineiro-de-administracao-escolar-na-gestao-das-escolas/> Acesso em: 08 fev 2018.

TRIPODI, M. do R. F. O estado contratual e a nova agenda da educação: o caso de Minas Gerais. Revista @ mbienteeducação. 5(1): 32-50, jan/jun, 2012. 
A Instituição da Agenda Contratual na Educação Mineira: Arquitetura de uma Reforma. Tese (Doutorado em Educação), Faculdade de Educação, Universidade de São Paulo, São Paulo, 2014.

TSCHANNEN-MORAN, M.; GAREIS, C. Principals' sense of efficacy: Assessing a promising constructo. Journal of Educational Administration - October 2004. Disponível em: <https://www.researchgate.net/publication/235281078< Acesso em: 21 nov 2018.

URICK, A.; BOWERS, A. J. What are the Different Types of Principals Across the United States? A Latent Class Analysis of Principal Perception of Leadership. Disponível em: <http://eaq.sagepub.com/content/50/1/96.full.pdf $>$. Acesso em: 03 out. 2015 .

VALLIN, C.; RUBIM, L. C. B. In: ALMEIDA, Maria Elizabeth Bianconcini de; ALONSO, Myrtes. (Orgs.). Tecnologias na Formação e na Gestão Escolar. São Paulo: Avercamp, 2007.

VELANDIA, S. A. T.; RÍOS, C. B.; LEÓN, O. G. P. de. Infraestructura tecnológica y apropiación de las TIC en la Universidad Autónoma del Estado de Morelos. Estudio de caso. Perfiles Educativos | vol. XXXII, núm. 127, 2010 | IISUE-UNAM. Disponível em: $<$ http://www.scielo.org.mx/pdf/peredu/v32n127/v32n127a6.pdf :Acesso em: 09 jul 2018.

VENTURA, R. de C. M. de O.; NASSIF, M. E.. Gestão de pessoas e suas relações com o compartilhamento da informação no contexto organizacional. Inf. \& Soc.:Est., João Pessoa, v.26, n.3, p. 221-234, set./dez. 2016 Disponível em: <http://www.periodicos.ufpb.br/index.php/ies/article/viewFile/30797/16881< Acesso em: 25 abr 2018.

VIEIRA, S. L.. Política(s) e Gestão da Educação Básica: revisitando conceitos simples. RBPAE - v.23, n.1, p. 53-69, jan./abr. 2007.

VINHA, T. P.; MORAIS, A. de; TOGNETTA, L. R. P.; AZZI, R. G.; ARAGÃO, A. M. F. de; MARQUES, C. de A. E.; SILVA, L. M. F. da; MORO, A.;

VIVALD, F. M. de C; RAMOS, A. de M.; OLIVEIRA, M. T. A.; BOZZA, T. C. L. O clima escolar e a convivência respeitosa nas instituições educativa. Est. Aval. Educ., São Paulo, v. 27, n. 64, p. 96-127, jan./abr. 2016. Disponível em: $<$ http://publicacoes.fcc.org.br/ojs/index.php/eae/article/view/3747/3157> Acesso em: 15 jun 2018.

WERLE, F. O. C.; AUDINO, J. F.. Desafios na gestão escolar. RBPAE - v. 31, n. 1 , p. $125 \quad$ - 144 jan./abr. 2015. Disponível em: <http://seer.ufrgs.br/index.php/rbpae/article/view/58921/35198> Acesso em: 10 jun 2018. 


\section{Anexos}

\section{Anexo 1:}

ESTADO DE MINAS GERAIS

SECRETARIA DE ESTADO DE EDUCAÇ̃̃o

SUBSECRETARIA DE INFORMACÕES E TECNOLOGGIAS EDUCACIONAIS

\section{AUTORIZAÇÃ̃O}

Autorizamos a realização da pesquisa "O Sistema Mineiro de Administração Escotar (SIMADE): uso dos dados pelos gestores das escolas públicas da rede estadual e pela équipe da Secretaria de Estado de Educaçcão de Minas Gerais". a ser conduzida pela doutoranda Carla da Conceição de Lima, pós-graduanda pela Pontifícia Universidade Católica do Rio de Janeiro (PUC-RIO), sob a orientação da Professora Dr $r^{\text {2}}$ Cynthia Paes de Carvalho (PUC-Rio). Esta investigação integra a pesquisa "Liderança. colaboração docente e qualidade da educação em diferentes contextos organizacionais" do grupo Gestão e Qualidade da Educação - GESQ, apoiada pela $\mathrm{CNPq}$.

O estudo foi autorizado pela Comissão de Ética em Pesquisa da PUC-Rio e tem como objetivo investigar o Sistema Mineiro de Administração Escolar (SIMADE) como ferramenta de gestão para os diretores das escolas da rede estadual e para a equipe da Secretaria de Estado da Educação de Minas Gerais (SEE/MG). A proposta de trabalho foi apresentada e discutida, com alguns integrantes da equipe do setor Subsecretaria de Informações e Tecnologias Educacionais. A pesquisa será realizada a partir da análise dos dados obtidos com a aplicação de dois questionários a serem enviados por e-mail para as escolas contendo:

(i) O link (endereço) do questionário a ser respondido pelo diretor(a) ou vice-diretor(a) escolar:

(ii) O link (endereço) do questionário a ser respondido pelo secretário escolar ou ATB responsável pela inserção de dados no SIMADE.

Não se descarta, entretanto, a utilização de cartas e teléfonemas para as escolas estaduais com intuito de informar sobre a pesquisa e solicitar a participaçã̀o de diretores e secretários.

A pesquisadora em tela, Carla da Conceição de Lima, juntamente com sua orientadora. Prof ${ }^{\mathrm{a}}$ $\mathrm{Dr}^{\mathrm{n}}$. Cynthia Paes de Carvalho se comprometem a resguardar a confiabilidade. o sigilo. a privacidade, a proteção da imagem e a não estigmatizar os participantes da pesquisa. garantindo a não utilização de informações em prejuizo das pessoas. inclusive no que tange sua autoestima, prestígio econômico ou financeiro. $A^{\prime}$ pesquisadora deve. ainda. apresentar os resultados do estudo à equipe da Secretaria de Educação quando da entrega do trabalho à instituição de ensino (PUC-Rion) ou quando solicitado.

Belo Horizonte. 24 de outubro de 2017

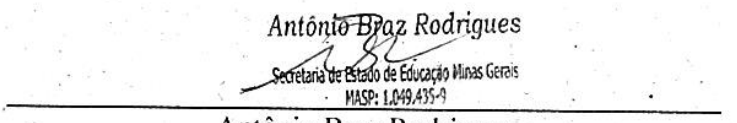

Antônio Braz Rodrigues

Superintendente de Informações Educacionais

Subsecretaria de Informações e Tecnologias Educacionais Secretária de Estado de Educação de Minas Gerais 


\section{Anexo 2: Cartas de apresentação dos questionários (MG)}
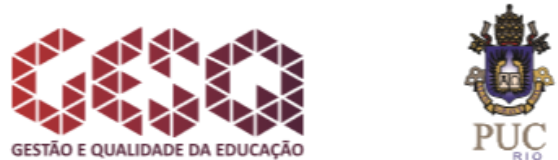

Carta de Apresentação

Carta de apresentação da pesquisa $O$ Sistema Mineiro de Administração Escolar (SIMADE): uso dos dados pelos gestores das escolas públicas da rede estadual e pela equipe da Secretaria de Estado de Educação de Minas Gerais

Caro(a) Diretor(a) da SRE

O grupo de pesquisa Gestão e Qualidade da Educação - GESQ - da Pontifícia Universidade Católica do Rio de Janeiro (PUC-Rio), sob a coordenação da professora $\mathrm{Dr}^{\mathrm{a}}$. Cynthia Paes de Carvalho, vem realizando, desde 2010, estudos sobre a gestão escolar nas redes públicas de educação básica. Dentre esses estudos, está a pesquisa " $O$ Sistema Mineiro de Administração Escolar (SIMADE): uso dos dados pelos gestores das escolas públicas da rede estadual e pela equipe da Secretaria de Estado de Educação de Minas Gerais", que pretende investigar o SIMADE como ferramenta de gestão para os diretores da rede estadual e para as equipes da Secretaria de Estado da Educação de Minas Gerais (SEE/MG). A pesquisa em tela é de autoria de Carla da Conceição de Lima, doutoranda em Educação pela PUC-Rio.

O estudo foi autorizado pela Comissão de Ética em Pesquisa da PUC-Rio, bem como apresentado e autorizado pela SEE/MG. Contamos com o imprescindível apoio do(a) diretor(a) da SRE e demais integrantes da equipe pedagógica da SRE para assegurar o contato e a participação dos diretores e secretários/ATBs das escolas estaduais mineiras, que é vital para o sucesso do trabalho e para que cheguemos a um cenário fidedigno sobre o uso dos dados do SIMADE. Todos os dados serão tratados com total sigilo, confiabilidade e apresentados de forma global, ou seja, sem qualquer possibilidade de identificação de informações específicas de cada participante da pesquisa.

Para a sua realização, serão enviados dois e-mails para a escola: (i) com o link (endereço) do questionário a ser respondido pelo diretor(a) ou vice-diretor(a) escolar; (ii) com o link (endereço) do questionário a ser respondido pelo secretário escolar ou ATB que seja responsável pela inserção de dados no SIMADE. Entretanto, não se descarta a utilização de cartas e telefonemas para as escolas estaduais mineiras com intuito de informar sobre a pesquisa e solicitar a participação de diretores e secretários. Os links dos questionários são:

Diretor(a)/ Vice-diretor da escola: https://pt.surveymonkey.com/r/Y2QVTSN

Secretário(a)/ATB: https://pt.surveymonkey.com/r/T89KGCT

Qualquer dúvida quanto aos questionários ou outras informações, estamos à disposição pelo e-mail contato@pesquisadegestao.com.br ou pelo telefone (32) 98892-6304.

Desde já agradecemos a sua colaboração.

Atenciosamente,

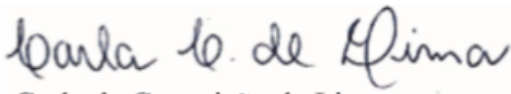

Carla da Conceição de Lima

Doutoranda

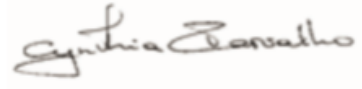

Cynthia Paes de Carvalho Orientadora 


\section{Carta de Apresentação}

Carta de apresentação da pesquisa $O$ Sistema Mineiro de Administração Escolar (SIMADE): uso dos dados pelos gestores das escolas públicas da rede estadual e pela equipe da Secretaria de Estado de Educação de Minas Gerais

Caro(a) Diretor(a) da SRE

O grupo de pesquisa Gestão e Qualidade da Educação - GESQ - da Pontificia Universidade Católica do Rio de Janeiro (PUC-Rio), sob a coordenação da professora $\mathrm{Dr}^{2}$. Cynthia Paes de Carvalho, vem realizando, desde 2010, estudos sobre a gestão escolar nas redes públicas de educação básica. Dentre esses estudos, está a pesquisa " $O$ Sistema Mineiro de Administração Escolar (SIMADE): uso dos dados pelos gestores das escolas públicas da rede estadual e pela equipe da Secretaria de Estado de Educação de Minas Gerais", que pretende investigar o SIMADE como ferramenta de gestão para os diretores da rede estadual e para as equipes da Secretaria de Estado da Educação de Minas Gerais (SEE/MG). A pesquisa em tela é de autoria de Carla da Conceição de Lima, doutoranda em Educação pela PUC-Rio.

O estudo foi autorizado pela Comissão de Ética em Pesquisa da PUC-Rio, bem como apresentado e autorizado pela SEE/MG. Contamos com o imprescindível apoio do(a) diretor(a) da SRE e demais integrantes da equipe pedagógica da SRE para assegurar o contato e a participação dos diretores e secretários/ATBs das escolas estaduais mineiras, que é vital para o sucesso do trabalho e para que cheguemos a um cenário fidedigno sobre o uso dos dados do SIMADE. Todos os dados serão tratados com total sigilo, confiabilidade e apresentados de forma global, ou seja, sem qualquer possibilidade de identificação de informações específicas de cada participante da pesquisa.

Para a sua realização, será enviado e-mail para a escola com o link (endereço) de dois questionários: (i) link (endereço) do questionário a ser respondido pelo diretor(a) ou vice-diretor(a) escolar; (ii) link (endereço) do questionário a ser respondido pelo secretário escolar ou ATB que seja responsável pela inserção de dados no SIMADE. Entretanto, não se descarta a utilização de cartas e telefonemas para as escolas estaduais mineiras com intuito de informar sobre a pesquisa e solicitar a participação de diretores e secretários. Os links dos questionários são:

Diretor(a)/ Vice-diretor da escola: https://pt.surveymonkey.com/r/Y2QVTSN

Secretário(a)/ATB: https://pt.surveymonkey.com/r/T89KGCT

Qualquer dúvida quanto aos questionários ou outras informações, estamos à disposição pelo e-mailcontato@pesquisadegestao.com.br ou pelo telefone (32) 98892-6304.

Desde já agradecemos a sua colaboração.

Atenciosamente,

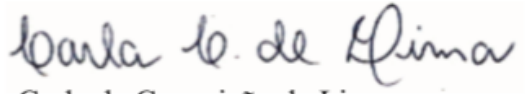

Carla da Conceição de Lima Doutoranda

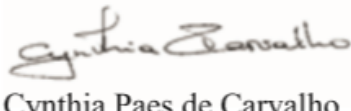

Orientadora 
Carta de apresentação que foi enviada por email aos diretores escolares

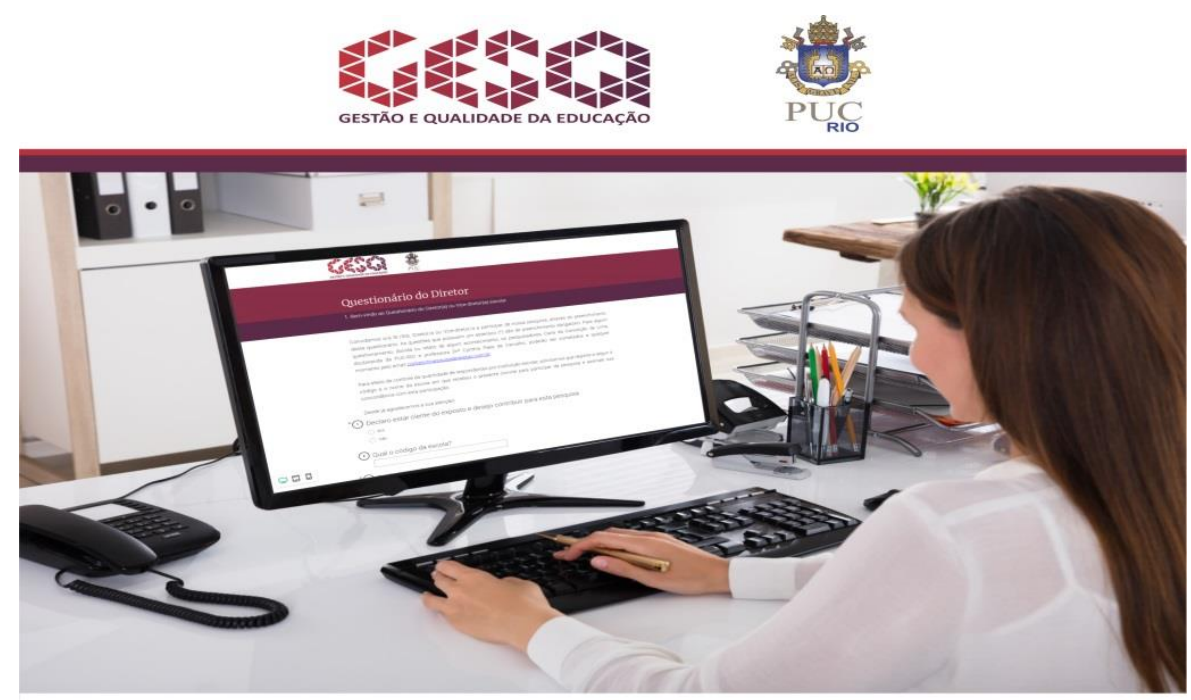

\section{SIMADE - Carta Convite}

Caro(a) diretor(a) ou Vice-diretor(a),

Pedimos a sua colaboração para responder ao questionário da pesquisa O Sistema Mineiro de Administração Escolar (SIMADE): uso dos dados pelos gestores das escolas públicas da rede estadual e pela equipe da Secretaria de Estado de Educação de Minas Gerais. O estudo foi autorizado pela Comissão de Ética em Pesquisa da PUC-Rio, bem como autorizado pela SEE/MG.

Esse questionário tem como objetivo coletar informaçōes sobre o SIMADE como ferramenta de gestão para os diretores da rede estadual. As informações obtidas a partir deste estudo podem contribuir para que cheguemos a um cenário fidedigno sobre o uso dos dados do SIMADE pelas escolas da rede estadual mineira. Portanto, sua participação é fundamental para o sucesso do estudo.

Você gastará apenas 15 minutos para responder ao questionário

Os dados produzidos não serão tratados de forma individual, ou seja, sem qualquer possibilidade de identificação de informações específicas de cada participante da pesquisa

Para começar a responder utilize o botão a seguir:

\section{Pesquisa SIMADE}

Muito obrigado pela sua colaboração

Carla da Conceição de Lima

Doutoranda - Currículo

Cynthia Paes de Carvalho

Orientadora - Curriculo

Qualquer dúvida quanto aos questionários ou outras informações, estamos à disposição:

E-mail: contato@pesquisadegestao.com.br

Telefone: (32) $98892-6304$

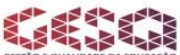

$$
\begin{aligned}
& \text { PU⿴囗十 } \\
& \text { MINAS AGERAIS } \\
& \text { Autorizaçẫo }
\end{aligned}
$$


Carta de apresentação que foi enviada por e-mail aos secretários escolares

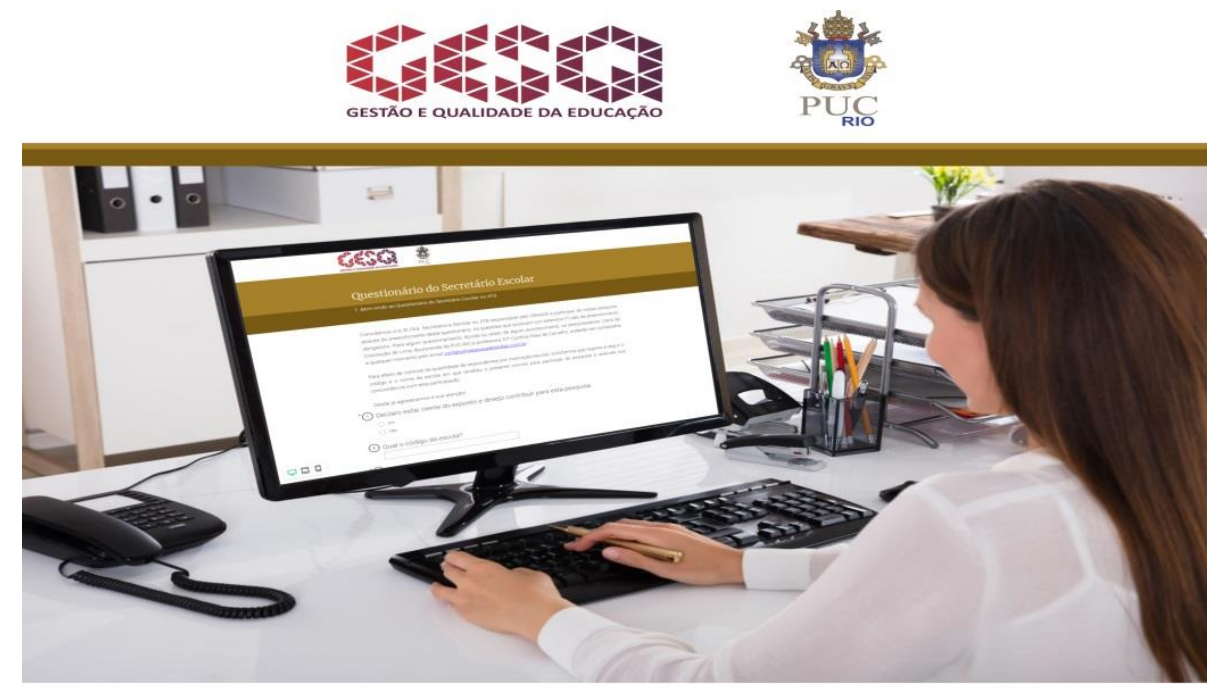

\section{SIMADE - Carta Convite}

Caro(a) Secretário(a) escolar ou ATB,

Pedimos a sua colaboração para responder ao questionário da pesquisa O Sistema Mineiro de Administração Escolar (SIMADE): uso dos dados pelos gestores das escolas públicas da rede estadual e pela equipe da Secretaria de Estado de Educação de Minas Gerais. O estudo foi autorizado pela Comissão de Ética em Pesquisa da PUC-Rio, bem como autorizado pela SEE/MG.

Esse questionário tem como objetivo coletar informações sobre o SIMADE como ferramenta para os secretários ou ATBs responsáveis pela inserção de dados no SIMADE. As informações obtidas a partir deste estudo podem contribuir para que cheguemos a um cenário fidedigno sobre o uso dos dados do SIMADE pelas escolas da rede estadual mineira. Portanto, sua participação é fundamental para o sucesso do estudo.

Você gastará apenas 15 minutos para responder ao questionário.

Os dados produzidos não serão tratados de forma individual, ou seja, sem qualquer possibilidade de identificação de informações específicas de cada participante da pesquisa.

Para começar a responder utilize o botão a seguir:

\section{Pesquisa SIMADE}

Muito obrigado pela sua colaboração.

Carla da Conceição de Lima

Doutoranda - Currículo

Cynthia Paes de Carvalho

Orientadora - Curriculo

Qualquer dúvida quanto aos questionários ou outras informações, estamos à disposiçẫo

E-mail: contato@pesquisadegestao.com.br

Telefone: (32) 9 8892-6304 


\section{Anexo 3}

Ajustes necessários aos questionários do pré-teste

\begin{tabular}{|c|c|c|c|}
\hline Questão & Situação & Motivo & Substituída por \\
\hline $\begin{array}{l}\text { Etapa(s) atendida(s) } \\
\text { pela escola: }\end{array}$ & $\begin{array}{l}\text { Questão } \\
\text { Excluída. }\end{array}$ & $\begin{array}{l}\text { Essa informação será } \\
\text { retirada do Censo } \\
\text { Escolar. }\end{array}$ & \\
\hline $\begin{array}{l}\text { Como você aprendeu a } \\
\text { usar o SisLAME? }\end{array}$ & $\begin{array}{l}\text { Questão } \\
\text { Alterada. }\end{array}$ & $\begin{array}{l}\text { O importante não era } \\
\text { saber como aprendeu mas } \\
\text { o que aprendeu. }\end{array}$ & $\begin{array}{l}\text { Caso tenha participado de } \\
\text { algum curso do SIMADE, } \\
\text { quais foram os assunto } \\
\text { tratados? }\end{array}$ \\
\hline $\begin{array}{l}\text { Quais as condições de } \\
\text { uso dos recursos: } \\
\text { computadores com } \\
\text { internet com conexão } \\
\text { banda larga: }\end{array}$ & $\begin{array}{l}\text { Alternativa } \\
\text { Excluída. }\end{array}$ & $\begin{array}{l}\text { Respondentes não sabiam } \\
\text { o que significava o termo } \\
\text { banda larga. }\end{array}$ & $\begin{array}{l}\text { Na escola, como você avalia o } \\
\text { acesso? }\end{array}$ \\
\hline $\begin{array}{l}\text { Quais as condições de } \\
\text { uso dos recursos: }\end{array}$ & $\begin{array}{l}\text { Questão } \\
\text { Alterada. }\end{array}$ & $\begin{array}{l}\text { Alguns computadores } \\
\text { ficavam fora da sala de } \\
\text { direção e da secretaria } \\
\text { escolar. }\end{array}$ & $\begin{array}{l}\text { Inserção das variáveis sala de } \\
\text { professor, sala de supervisão e } \\
\text { computadores portáteis. }\end{array}$ \\
\hline $\begin{array}{l}\text { Indique com que } \\
\text { frequência } \\
\text { diretor/você utiliza os } \\
\text { dados do } \\
\text { para: }\end{array}$ & $\begin{array}{lr}\text { (i)inserção } & \text { de } \\
\text { alternativa } & \text { de } \\
\text { resposta; } & \text { (ii) } \\
\text { alteração } & \text { do } \\
\text { formato } & \end{array}$ & $\begin{array}{l}\text { (i)Alternativas } \\
\text { rendimento sobre } \\
\text { desempenho não se } \\
\text { enquadravam em escolas } \\
\text { que atendiam a Educação } \\
\text { Infantil } \\
\text { (ii) facilitar } \quad \text { o } \\
\text { entendimento da questão. }\end{array}$ & $\begin{array}{l}\text { Inserção da alternativa de } \\
\text { resposta Nunca, } \\
\text { (ii) questão do tipo caixa de } \\
\text { seleção }{ }^{160} \text {. }\end{array}$ \\
\hline $\begin{array}{l}\text { Com que frequência } \\
\text { o(a) diretor(a) acessa o } \\
\text { SisLAME? }\end{array}$ & $\begin{array}{l}\text { Questão } \\
\text { alterada. }\end{array}$ & $\begin{array}{l}\text { Não apresenta quais } \\
\text { dados têm sido utilizados } \\
\text { pelos gestores. }\end{array}$ & $\begin{array}{l}\text { Gerou outras duas questões: O } \\
\text { diretor acessa o SIMADE?; } \\
\text { Caso tenha respondido sim na } \\
\text { pergunta anterior, informe para } \\
\text { que o diretor acessa o } \\
\text { SIMADE? }\end{array}$ \\
\hline Código da Escola. & $\begin{array}{l}\text { Alteração de } \\
\text { formato. }\end{array}$ & $\begin{array}{l}\text { Respondentes não sabiam } \\
\text { se era o código do INEP } \\
\text { ou do SisLAME. }\end{array}$ & $\begin{array}{l}\text { Tornou-se uma pergunta de } \\
\text { resposta não obrigatória. }\end{array}$ \\
\hline $\begin{array}{l}\text { Data } \\
\text { preenchimento. }\end{array}$ & $\begin{array}{l}\text { Questão } \\
\text { Excluída. }\end{array}$ & $\begin{array}{lr}\text { O Survey } & \text { Monkey } \\
\text { apresenta } & \text { essa } \\
\text { informação. } & \\
\end{array}$ & - \\
\hline $\begin{array}{l}\text { Entre os aspectos } \\
\text { abaixo, com qual deles } \\
\text { o diretor /você gasta a } \\
\text { maior parte do tempo } \\
\text { de trabalho na escola? }\end{array}$ & $\begin{array}{l}\text { (i)alteração de } \\
\text { formato; (ii) } \\
\text { alteração do } \\
\text { enunciado; } \\
\text { (iii) opções de } \\
\text { resposta. }\end{array}$ & $\begin{array}{l}\text { (i) respondentes } \\
\text { selecionavam mais de } \\
\text { uma resposta; } \\
\text { (ii) deixar mais clara a } \\
\text { questão; } \\
\text { (iii) para permitir } \\
\text { responder mais de uma } \\
\text { alternativa. }\end{array}$ & $\begin{array}{l}\text { (i) formato matriz/escala de } \\
\text { avaliação }{ }^{161} \text {; } \\
\text { (ii) Enunciado passou a ser Em } \\
\text { uma semana, quantas horas } \\
\text { você/o diretor dedica? } \\
\text { (iii) as opções de respostas } \\
\text { passaram a contemplar a } \\
\text { quantidade de horas dedicas a } \\
\text { cada aspecto da gestão. }\end{array}$ \\
\hline $\begin{array}{l}\text { Por quanto tempo você } \\
\text { trabalhou como } \\
\text { professor antes de } \\
\text { exercer uma função na }\end{array}$ & $\begin{array}{l}\text { (i) alteração no } \\
\text { formato da } \\
\text { questão. }\end{array}$ & $\begin{array}{lr}\text { (i) as alternativas } & \text { de } \\
\text { respostas } & \text { não } \\
\text { contemplavam } & \text { a } \\
\text { realidade. } & \\
\end{array}$ & $\begin{array}{l}\text { (i) tornou-se uma questão } \\
\text { aberta }\end{array}$ \\
\hline
\end{tabular}

${ }^{160}$ É um tipo de questão fechada que possibilita que os respondentes selecionem várias respostas em uma lista definida de opções.

${ }^{161}$ Uma pergunta do tipo Matriz/escala de avaliação é uma questão fechada que solicita que os respondentes avaliem um ou mais itens de linha utilizando o mesmo conjunto de opções de coluna, permitindo atribuir pesos a cada opção de resposta. 


\begin{tabular}{|c|c|c|c|}
\hline Questão & Situação & Motivo & Substituída por \\
\hline $\begin{array}{l}\text { secretaria da escola/ } \\
\text { antes de se tornar } \\
\text { diretor(a)/vice- } \\
\text { diretor(a)/coordenador( } \\
\text { a)? }\end{array}$ & & & \\
\hline $\begin{array}{l}\text { Tempo de atuação na } \\
\text { função e tempo de } \\
\text { atuação na escola. }\end{array}$ & $\begin{array}{l}\text { (i) alteração no } \\
\text { formato da } \\
\text { questão. }\end{array}$ & $\begin{array}{lr}\text { i) as alternativas } & \text { de } \\
\text { respostas } & \text { não } \\
\text { contemplavam } & \mathrm{a} \\
\text { realidade. } & \end{array}$ & $\begin{array}{l}\text { (i) tornaram-se questões } \\
\text { abertas. }\end{array}$ \\
\hline $\begin{array}{l}\text { Todas que tinham no } \\
\text { enunciado ou como } \\
\text { variáveis a palavra } \\
\text { coordenador(a). }\end{array}$ & $\begin{array}{l}\text { (i)a palavra } \\
\text { coordenador(a } \\
\text { ) foi excluída. }\end{array}$ & $\begin{array}{l}\text { (ii) não eram autorizados } \\
\text { pelo equipe diretiva a } \\
\text { responder o questionário; } \\
\text { nem sempre tinham } \\
\text { acesso ao sistema. }\end{array}$ & - \\
\hline $\begin{array}{ll}\text { Questões } & \text { sobre } \\
\text { escolaridade. } & \end{array}$ & $\begin{array}{l}\text { (i)desmembra } \\
\text { da em quatro } \\
\text { questões. }\end{array}$ & $\begin{array}{l}\text { (i) entender um pouco } \\
\text { mais sobre a formação } \\
\text { dos respondentes. }\end{array}$ & $\begin{array}{l}\text { Titulação; nome do curso na } \\
\text { graduação; tipo de instituição } \\
\text { que se graduou e qual o curso } \\
\text { de pós-graduação. }\end{array}$ \\
\hline $\begin{array}{l}\text { Indique com que } \\
\text { frequência você realiza } \\
\text { as seguintes atividades } \\
\text { no seu trabalho na } \\
\text { direção escolar: }\end{array}$ & $\begin{array}{l}\text { (i) Exclusão de } \\
\text { variáveis } \\
\text { (ii) Inserção de } \\
\text { variáveis }\end{array}$ & $\begin{array}{l}\text { (i) e (ii) objetivo foi } \\
\text { deixar e inserir variáveis } \\
\text { mais próximas das } \\
\text { atividades realizadas no } \\
\text { cotidiano de diretores e } \\
\text { secretários }\end{array}$ & $\begin{array}{l}\text { (i) e (ii) as questão incluídas a } \\
\text { satisfação em relação ao } \\
\text { trabalho, volume de trabalho e } \\
\text { as relações entre secretário e } \\
\text { diretor; recurso financeiros e } \\
\text { projetos encaminhados pela } \\
\text { SRE e SEE/MG }\end{array}$ \\
\hline $\begin{array}{lll}\text { Questões sobre } & \mathrm{o} \\
\text { conhecimento } & \mathrm{e} \\
\text { percepção sobre } & \mathrm{o} \\
\text { SisLAME } & & \end{array}$ & $\begin{array}{l}\text { (i)junção das } \\
\text { questões }\end{array}$ & $\begin{array}{l}\text { (i)Similaridade das } \\
\text { variáveis e das respostas } \\
\text { de diretores e secretários; } \\
\text { (ii) Foram eliminadas } \\
\text { duas variáveis de cada } \\
\text { questão }\end{array}$ & 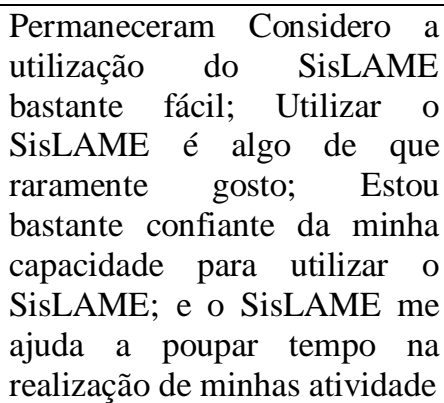 \\
\hline $\begin{array}{llr}\text { Indique } & \text { a } & \text { sua } \\
\text { percepção } & \text { sobre } & \text { a } \\
\text { usabilidade } & & \end{array}$ & $\begin{array}{l}\text { (i)inserção de } \\
\text { mais variáveis }\end{array}$ & $\begin{array}{l}\text { Alternativas estavam só } \\
\text { voltadas para a interface } \\
\text { do sistema }\end{array}$ & $\begin{array}{l}\text { Inserção de variáveis sobre a } \\
\text { confiança em relação ao } \\
\text { sistema; necessidades eram } \\
\text { atendidas; facilidade de } \\
\text { aprendizagem e se o sistema } \\
\text { funciona sem erros e } \\
\text { interrupções. }\end{array}$ \\
\hline $\begin{array}{lr}\text { Cite exemplos } & \text { de } \\
\text { situações em } & \text { que o } \\
\text { diretor } & \text { solicita } \\
\text { informações } & \\
\text { disponibilizadas } & \text { pelo } \\
\text { SisLAME. } & \\
\end{array}$ & $\begin{array}{l}\text { (i) Alteração } \\
\text { do formato da } \\
\text { questão. }\end{array}$ & $\begin{array}{l}\text { Como questão aberta as } \\
\text { respostas não estavam } \\
\text { condizentes com a } \\
\text { pergunta. }\end{array}$ & $\begin{array}{l}\text { Como questão fechada o } \\
\text { respondente pode apenas } \\
\text { escolher uma ou mais opções. }\end{array}$ \\
\hline $\begin{array}{lr}\text { Cite exemplos de } \\
\text { situações em que você } \\
\text { utiliza os dados } \\
\text { disponibilizados pelo } \\
\text { SisLAME. }\end{array}$ & $\begin{array}{l}\text { (i)Alteração } \\
\text { do formato da } \\
\text { questão. }\end{array}$ & $\begin{array}{l}\text { Como questão aberta as } \\
\text { respostas não estavam } \\
\text { condizentes com a } \\
\text { pergunta. }\end{array}$ & $\begin{array}{l}\text { Como questão fechada o } \\
\text { respondente pode apenas } \\
\text { escolher uma ou mais opções. }\end{array}$ \\
\hline
\end{tabular}

Fonte: Questionário do pré-teste (diretor e secretário). 


\section{Anexo 4 - Questionários alicados nas escolas de MG}

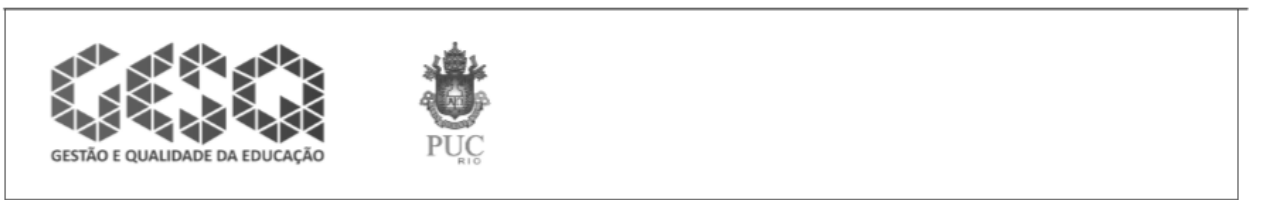

Questionário do Diretor

1. Bem-vindo ao Questionário do Diretor(a) ou Vice-diretor(a) escolar

Convidamos ola Sr./Sra. Diretorla ou Vice-diretorla a participar de nossa pesquisa, através do preenchimento deste questionário. As questões que possuem um asterisco (*) são de preenchimento obrigatório. Para algum questionamento, dúvida ou relato de algum acontecimento, os pesquisadores, Carla da Conceição de Lima, doutoranda da PUC-RIO e professora Dra Cynthia Paes de Carvalho, poderão ser contatados a qualquer momento pelo email contato@pesquisadegestao.com.br

Para efeito de controle da quantidade de respondentes por instituição escolar, solicitamos que registre a seguir o código e o nome da escola em que recebeu o presente convite para participar da pesquisa e assinale sua concordância com esta participação.

Desde já agradecemos a sua atenção!

* 1. Declaro estar ciente do exposto e desejo contribuir para esta pesquisa

$\bigcirc \operatorname{Sim}$

Não

2. Qual o código da escola?

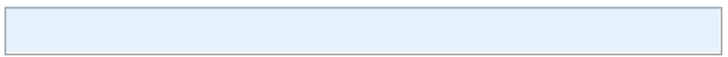

* 3. Qual o nome da escola

* 4. Qual o seu cargo?

Diretor(a)

Vice-diretor(a)

* 5. Você pretende continuar na direção desta escola nos próximos anos?

Não

Sim

6. Em relação a pergunta anterior, registro os motivos que o levam/levaram a essa decisão: 
* 7. Em sua função de diretor, o quanto você consegue:

Planejar e cumprir as
atividades de seu
trabalho
Resolver os problemas
burocráticos inerentes à
função
Apoiar o trabalho
pedagógico dos
professores
Elevar o desempenho
dos alunos no SIMAVE
Usar o SIMADE em
aspectos pedagógicos
(analisar o desempenho
dos alunos)
Usar o SIMADE em
aspectos
administrativos
(organizar horários)

* 8. Em uma semana, quantas horas você dedica:

\begin{tabular}{|c|c|c|c|c|c|c|}
\hline & $\begin{array}{c}\text { Entre } 1 \text { e } 5 \\
\text { horas }\end{array}$ & De 6 a 10 horas & $\begin{array}{c}\text { De } 11 \text { a } 20 \\
\text { horas }\end{array}$ & $\begin{array}{c}\text { De } 21 \text { a } 30 \\
\text { horas }\end{array}$ & $\begin{array}{c}\text { Mais de } 30 \\
\text { horas }\end{array}$ & Não se aplica \\
\hline \multicolumn{7}{|l|}{$\begin{array}{l}\text { À Gestão de pessoal } \\
\text { (administração das relações } \\
\text { entre professores e entre } \\
\text { funcionários, controle de } \\
\text { faltas e licenças) }\end{array}$} \\
\hline \multicolumn{7}{|l|}{$\begin{array}{l}\text { À Gestão administrativa } \\
\text { (prestação de contas, } \\
\text { coleta de orçamentos, } \\
\text { organização de horários, } \\
\text { controles financeiros) }\end{array}$} \\
\hline \multicolumn{7}{|l|}{$\begin{array}{l}\text { A aspectos pedagógicos } \\
\text { (discussões sobre o } \\
\text { currículo, metodologia de } \\
\text { ensino, análise de } \\
\text { desempenho e disciplina e } \\
\text { comportamento dos alunos) }\end{array}$} \\
\hline $\begin{array}{l}\text { A relações externas } \\
\text { (atendimento aos pais, } \\
\text { reuniões na SRE, } \\
\text { organização/monitoramento } \\
\text { de parcerias) }\end{array}$ & & & & & & \\
\hline
\end{tabular}




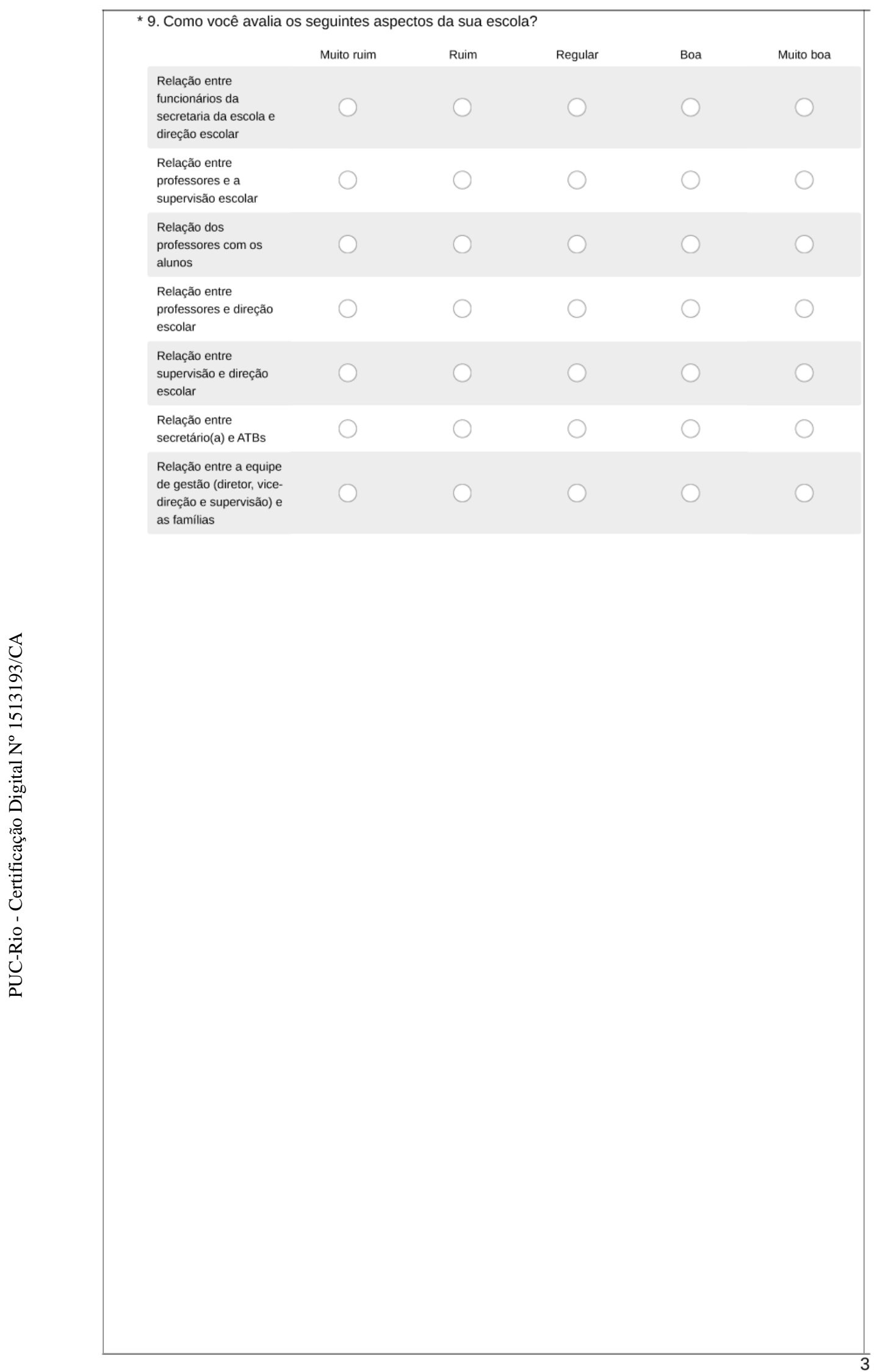




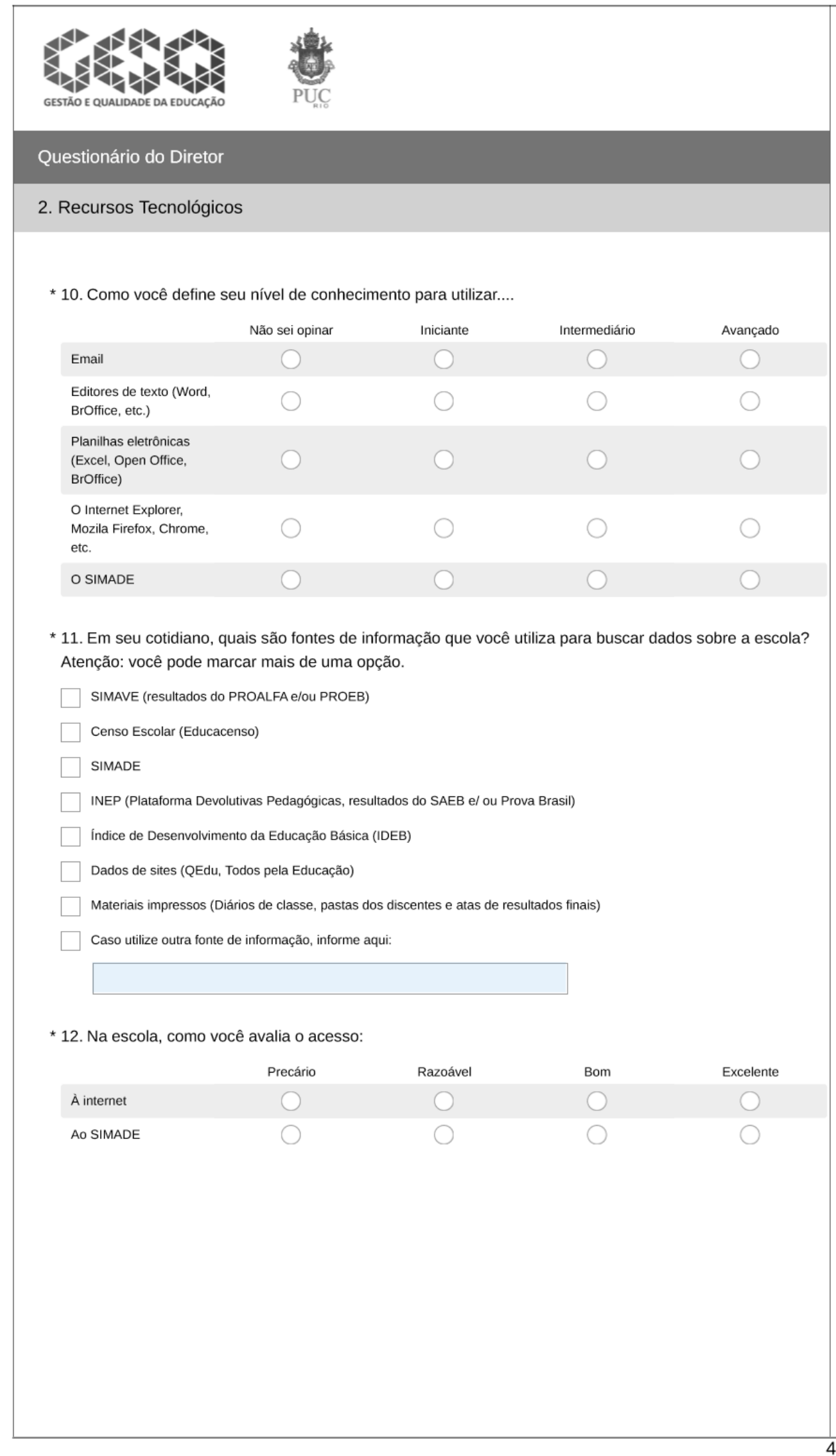




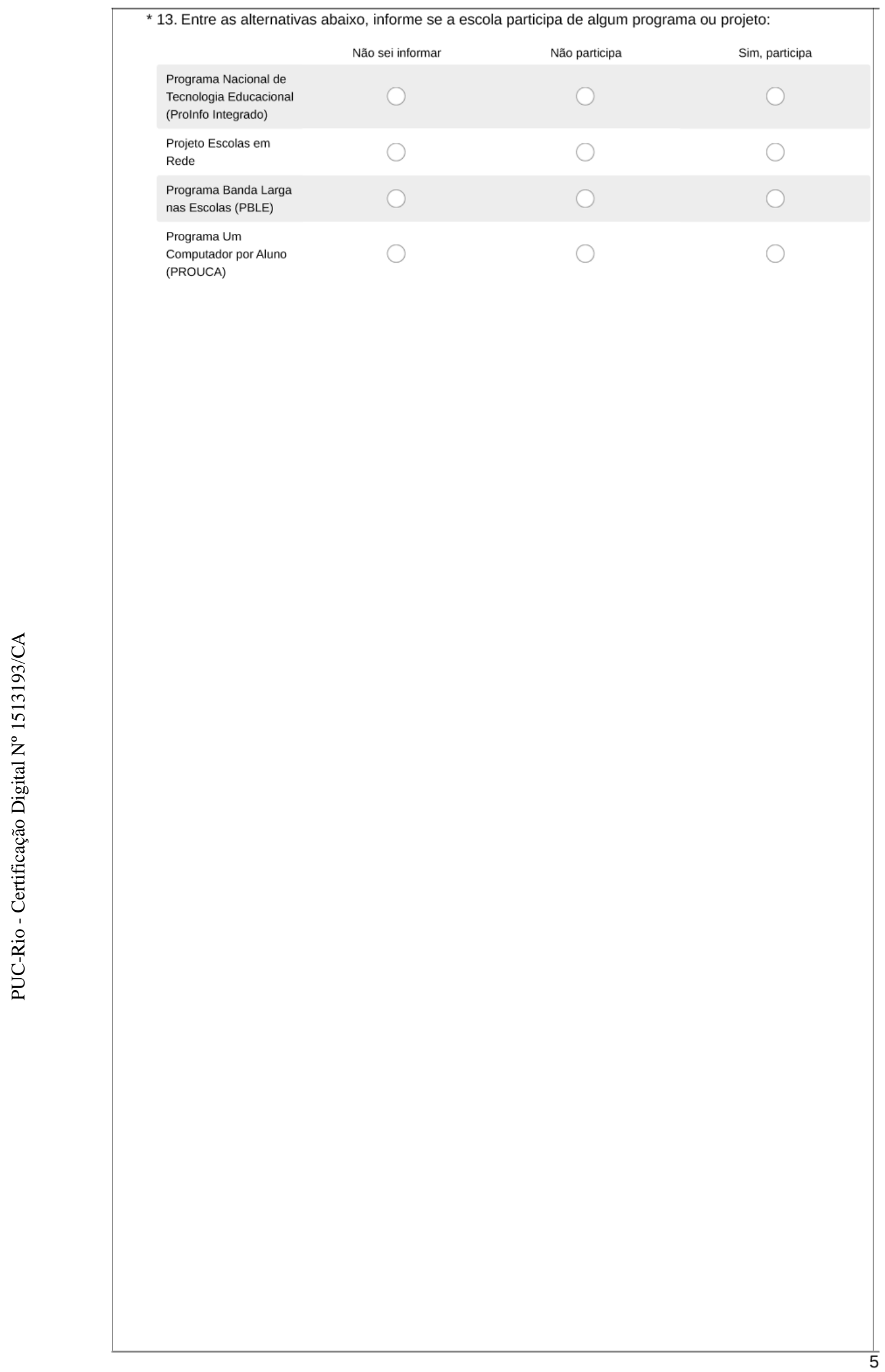




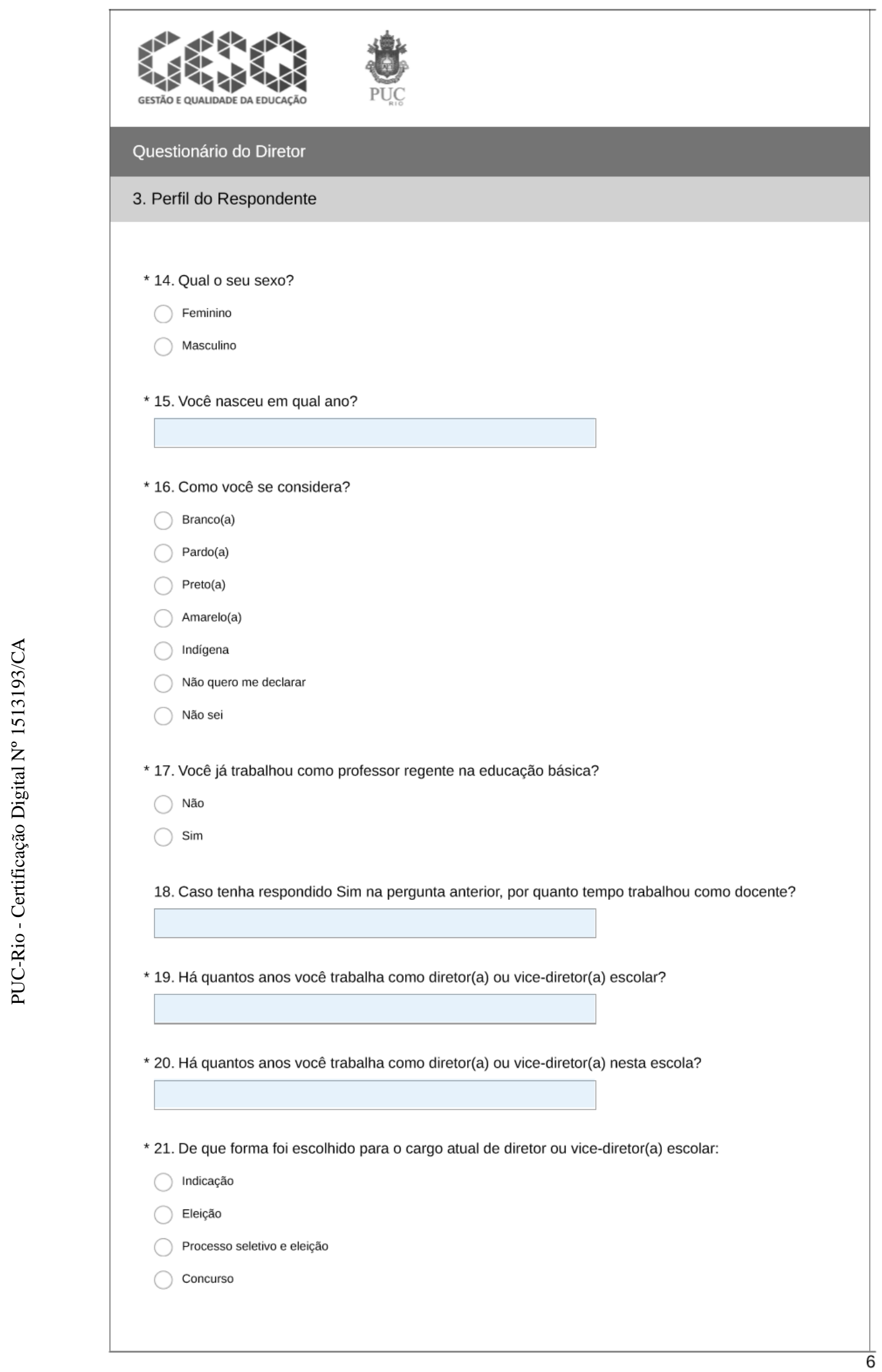


* 22. Qual o seu grau máximo de escolarização concluída?

Ensino Fundamental

Curso Normal de Nível Médio

Ensino Médio Técnico ou antigo $2^{\circ} \mathrm{grau}$

Ensino Superior

Especialização

Mestrado

Doutorado

23. Caso você tenha feito ensino superior, especifique o curso:

24. Caso tenha feito ensino superior, em que tipo de instituição se graduou?

Pública

Privada

25. Caso você tenha feito pós-graduação, especifique o curso:

* 26. Nos últimos três anos, você participou de alguma atividade de formação continuada?

Não

$\operatorname{Sim}$

Curso de qualificação

na área de gestão

escolar/educacional

SIMADE

Apropriação de

resultados (PROEB e/ou

PROALFA)

* 27. Caso tenha participado de algum curso sobre o SIMADE, quais foram os assuntos tratados? Atenção: você pode marcar mais de uma resposta.

Não participei de nenhum curso sobre o SIMADE

Cadastro, Matrícula, Enturmação, Avaliação, Frequência e Histórico

Dados de preenchimento obrigatório para migração para o Censo Escolar

Emissão de declarações, boletins, atas e mapa de desempenho

Criar Pacote, Programa Pedagógico, Cadastro de Turma e Encerramento do Período Letivo

Caso o(s) assunto(s) tenha(m) sido outro(s), informe abaixo: 


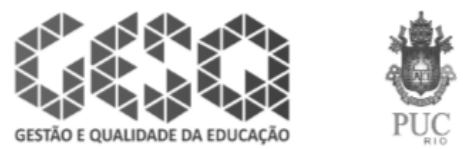

Questionário do Diretor

4. Gestão da Escola

* 28. Sobre o seu trabalho na direção desta escola, marque qual é o seu nível de concordância com cada uma das afirmativas abaixo:

\begin{tabular}{|c|c|c|c|c|}
\hline & Discordo totalmente & Discordo em parte & Concordo em parte & Concordo totalmente \\
\hline \multicolumn{5}{|l|}{$\begin{array}{l}\text { Sinto-me satisfeito com } \\
\text { as relações } \\
\text { estabelecidas no meu } \\
\text { local de trabalho }\end{array}$} \\
\hline \multicolumn{5}{|l|}{$\begin{array}{l}\text { Sinto-me estressado (a) } \\
\text { com o volume de } \\
\text { demandas que o } \\
\text { trabalho da direção } \\
\text { escolar me exige }\end{array}$} \\
\hline \multicolumn{5}{|l|}{$\begin{array}{l}\text { Sinto-me pouco } \\
\text { apoiado(a) em relação } \\
\text { aos recursos financeiros } \\
\text { e pessoais necessários } \\
\text { para manter o pleno } \\
\text { funcionamento da escola }\end{array}$} \\
\hline $\begin{array}{l}\text { Sinto-me frustrado(a) } \\
\text { pelo pouco controle e } \\
\text { baixa interferência que } \\
\text { tenho sobre os projetos } \\
\text { encaminhados pela SRE } \\
\text { e pela SEE para a escola }\end{array}$ & & & & \\
\hline \multicolumn{5}{|l|}{$\begin{array}{l}\text { Divido responsabilidades } \\
\text { do SIMADE com a } \\
\text { equipe da secretaria da } \\
\text { escola }\end{array}$} \\
\hline \multicolumn{5}{|l|}{$\begin{array}{l}\text { O planejamento anual } \\
\text { das atividades é } \\
\text { elaborado com a } \\
\text { participação dos } \\
\text { professores e demais } \\
\text { profissionais da escola }\end{array}$} \\
\hline $\begin{array}{l}\text { Para tomar decisões, } \\
\text { ouço os profissionais da } \\
\text { escola }\end{array}$ & & & & \\
\hline
\end{tabular}




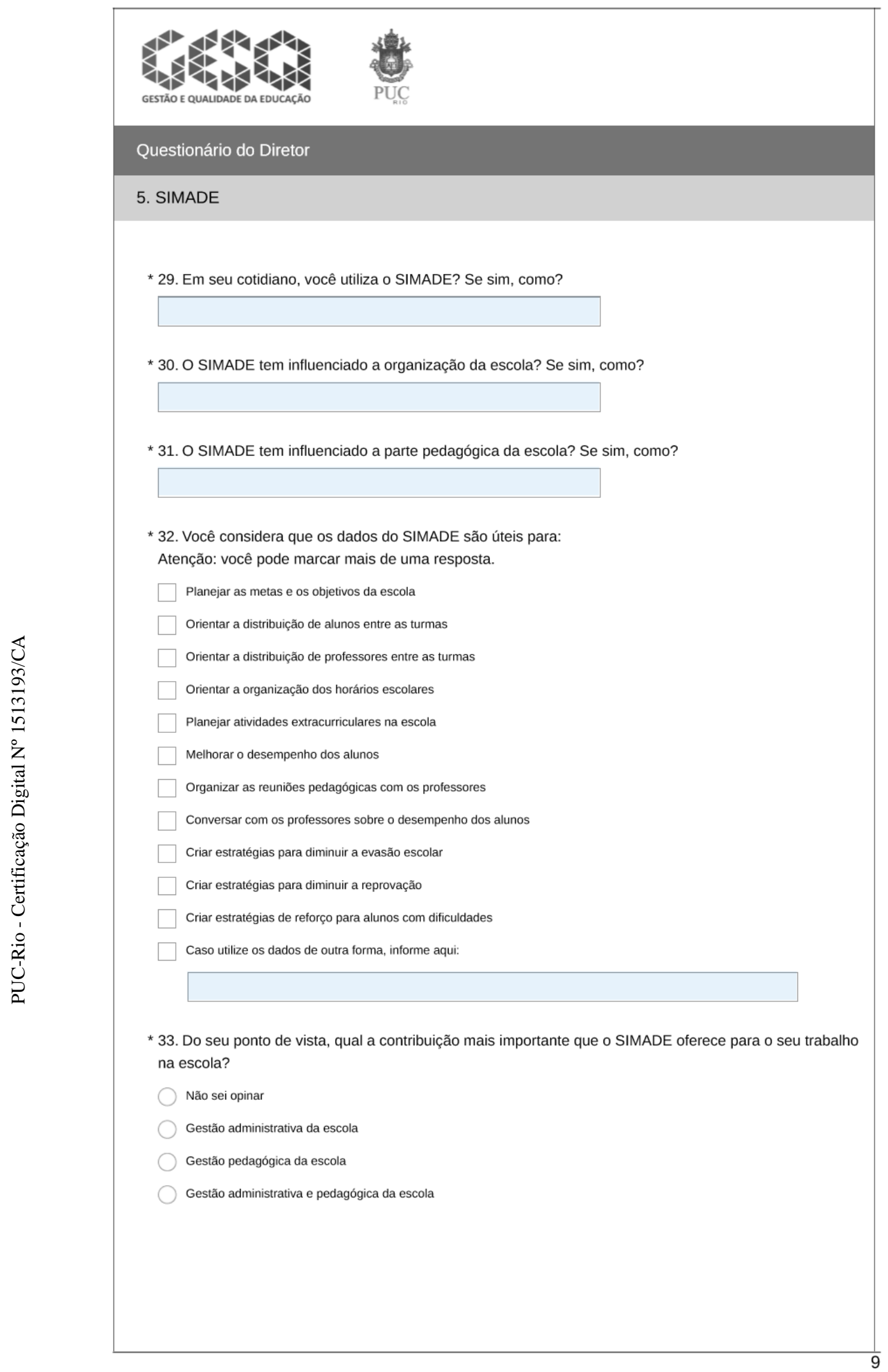




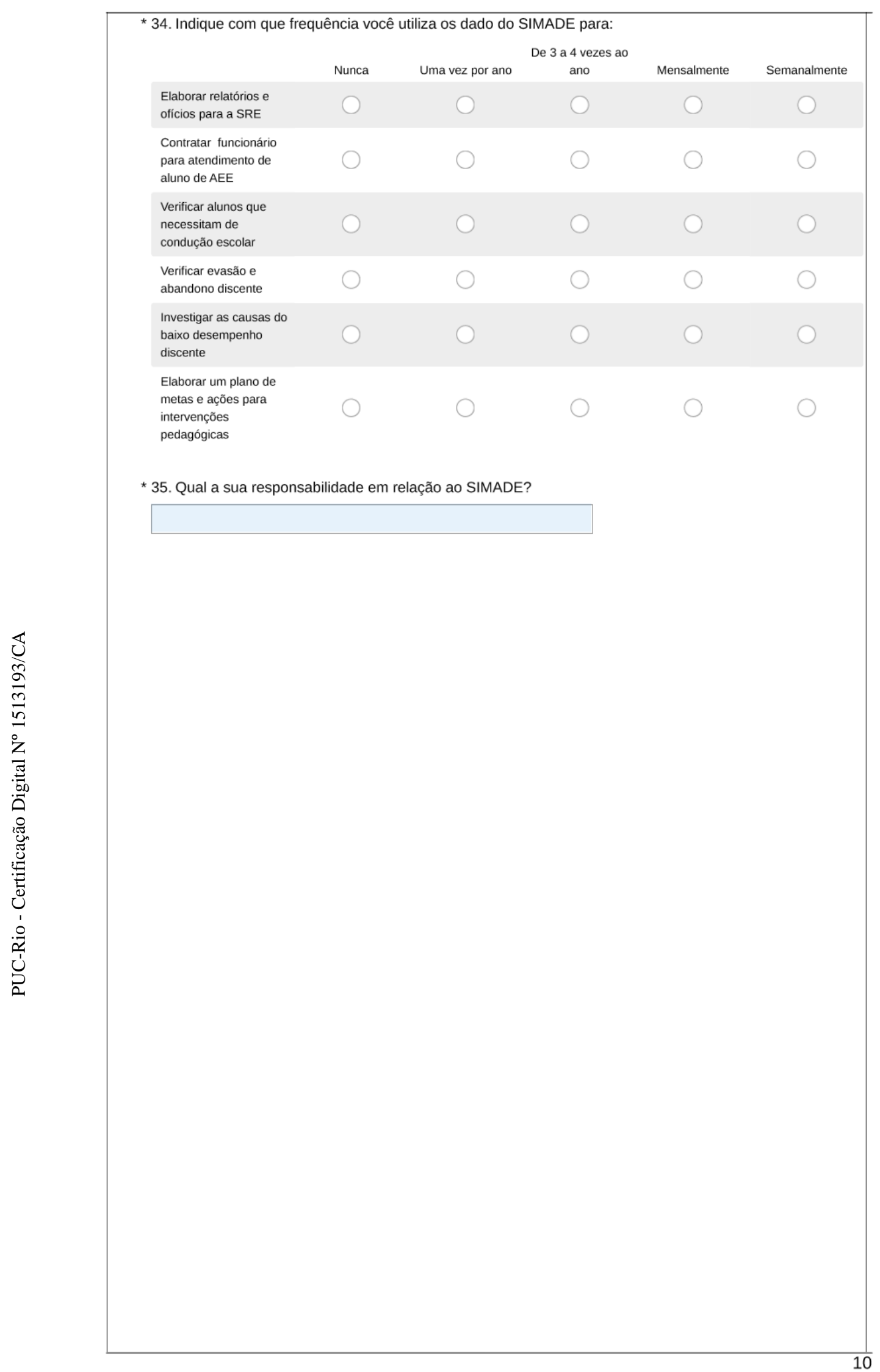




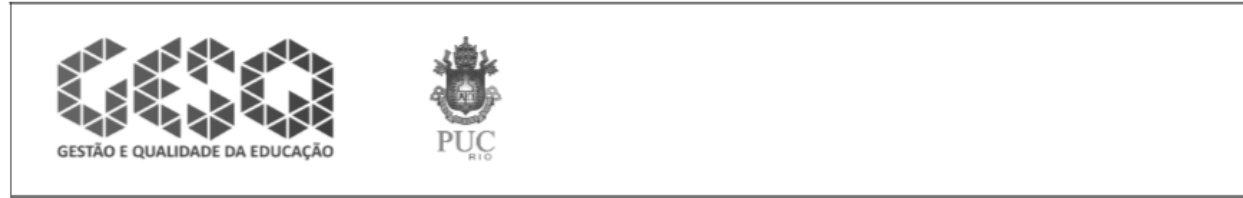

Questionário do Diretor

6. SIMADE

* 36 . Você utiliza os dados do SIMADE nas:

Reuniões pedagógicas
Conversas com os pais
Transmissões de
informações para a SRE
Visitas das inspetoras
escolares

* 37. Considerando o seu trabalho na direção desta escola, marque qual é o seu nível de concordância com cada uma das afirmativas abaixo:

\begin{tabular}{|c|c|c|c|c|}
\hline & Discordo totalmente & Discordo em parte & Concordo em parte & Concordo totalmente \\
\hline \multicolumn{5}{|l|}{$\begin{array}{l}\text { Considero a utilização } \\
\text { do SIMADE bastante } \\
\text { fácil }\end{array}$} \\
\hline \multicolumn{5}{|l|}{$\begin{array}{l}\text { Utilizar o SIMADE é algo } \\
\text { que raramente gosto }\end{array}$} \\
\hline \multicolumn{5}{|l|}{$\begin{array}{l}\text { Estou bastante } \\
\text { confiante na minha } \\
\text { capacidade para utilizar } \\
\text { o SIMADE }\end{array}$} \\
\hline $\begin{array}{l}\text { O SIMADE me ajuda a } \\
\text { poupar tempo na } \\
\text { realização de minhas } \\
\text { atividades }\end{array}$ & & & & \\
\hline
\end{tabular}




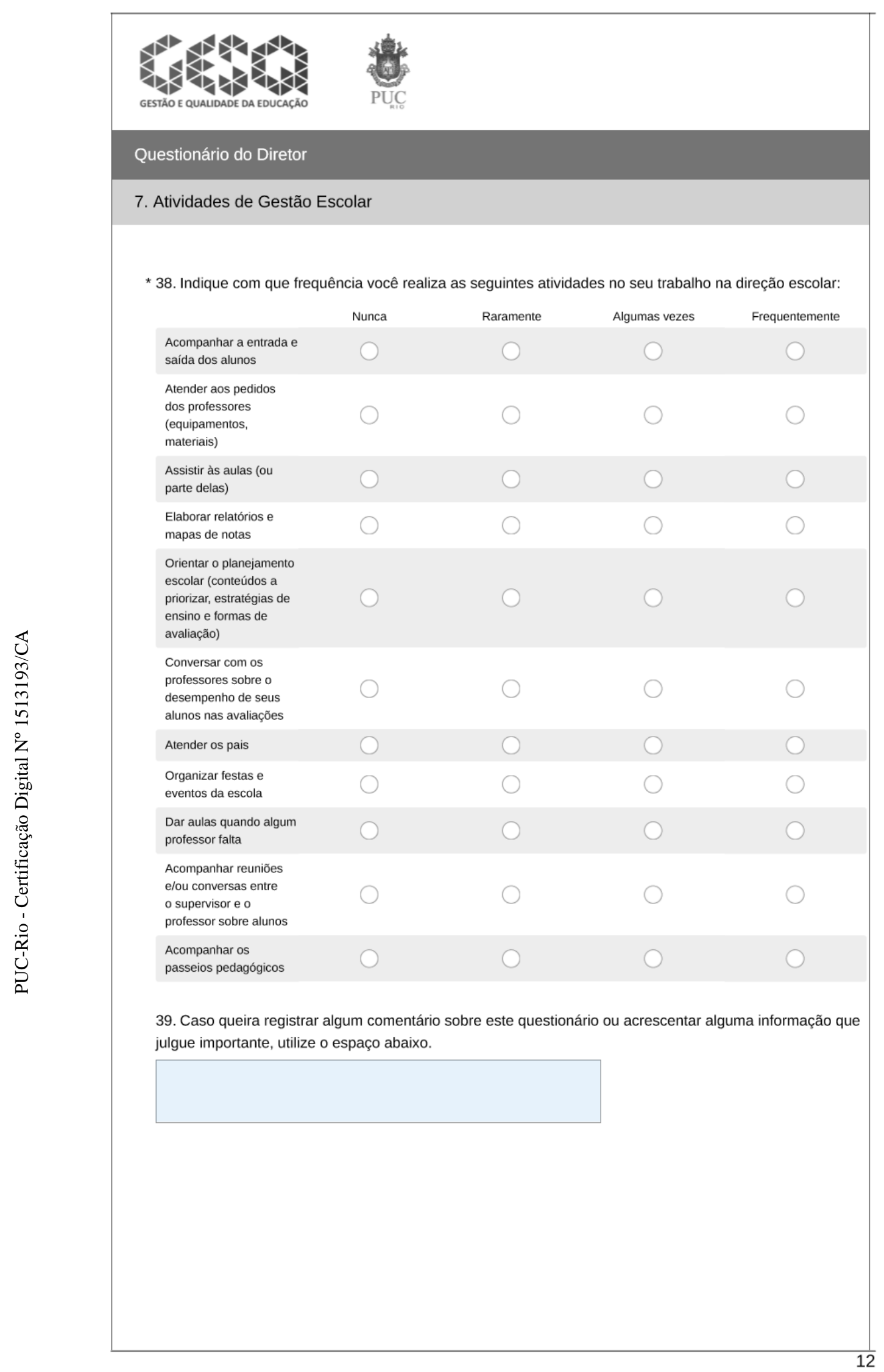




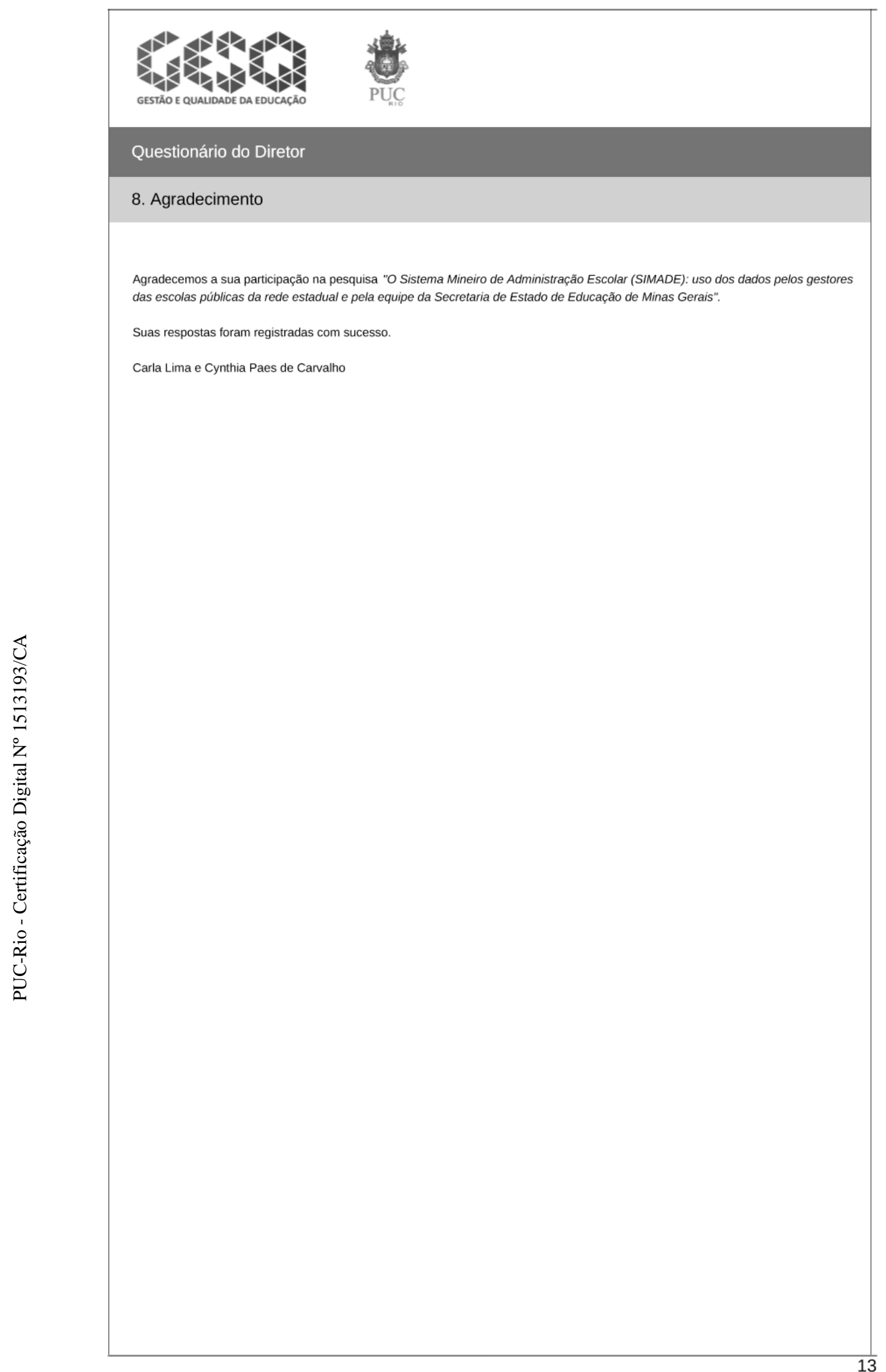


Questionário do secretário (MG)

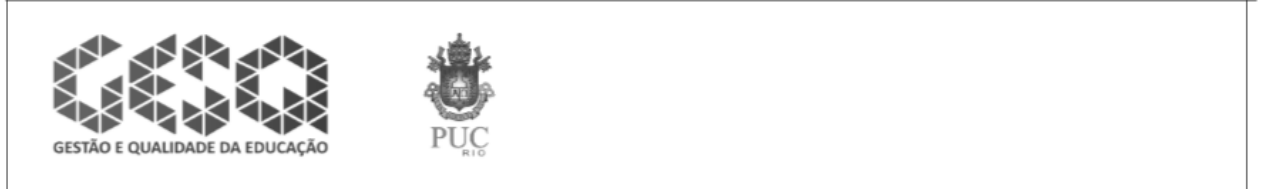

Questionário do Secretário Escolar

1. Bem-vindo ao Questionário do Secretário Escolar ou ATB

Convidamos ola Sr./Sra. Secretáriola Escolar ou ATB responsável pelo SIMADE a participar de nossa pesquisa, através do preenchimento deste questionário. As questões que possuem um asterisco (*) são de preenchimento obrigatório. Para algum questionamento, dúvida ou relato de algum acontecimento, os pesquisadores, Carla da Conceição de Lima, doutoranda da PUC-RIO e professora Dra Cynthia Paes de Carvalho, poderão ser contatados a qualquer momento pelo email contato@pesquisadegestao.com.br

Para efeito de controle da quantidade de respondentes por instituição escolar, solicitamos que registre a seguir o código e o nome da escola em que recebeu o presente convite para participar da pesquisa e assinale sua concordância com esta participação.

Desde já agradecemos a sua atenção!

* 1. Declaro estar ciente do exposto e desejo contribuir para esta pesquisa

Sim

Não

2. Qual o código da escola?

3. Qual o nome da escola?

* 4. Qual o seu cargo?

Secretário(a)

ATB

* 5. Qual o ano em que você nasceu?

*6. Qual o seu sexo?

Feminino

Masculino 


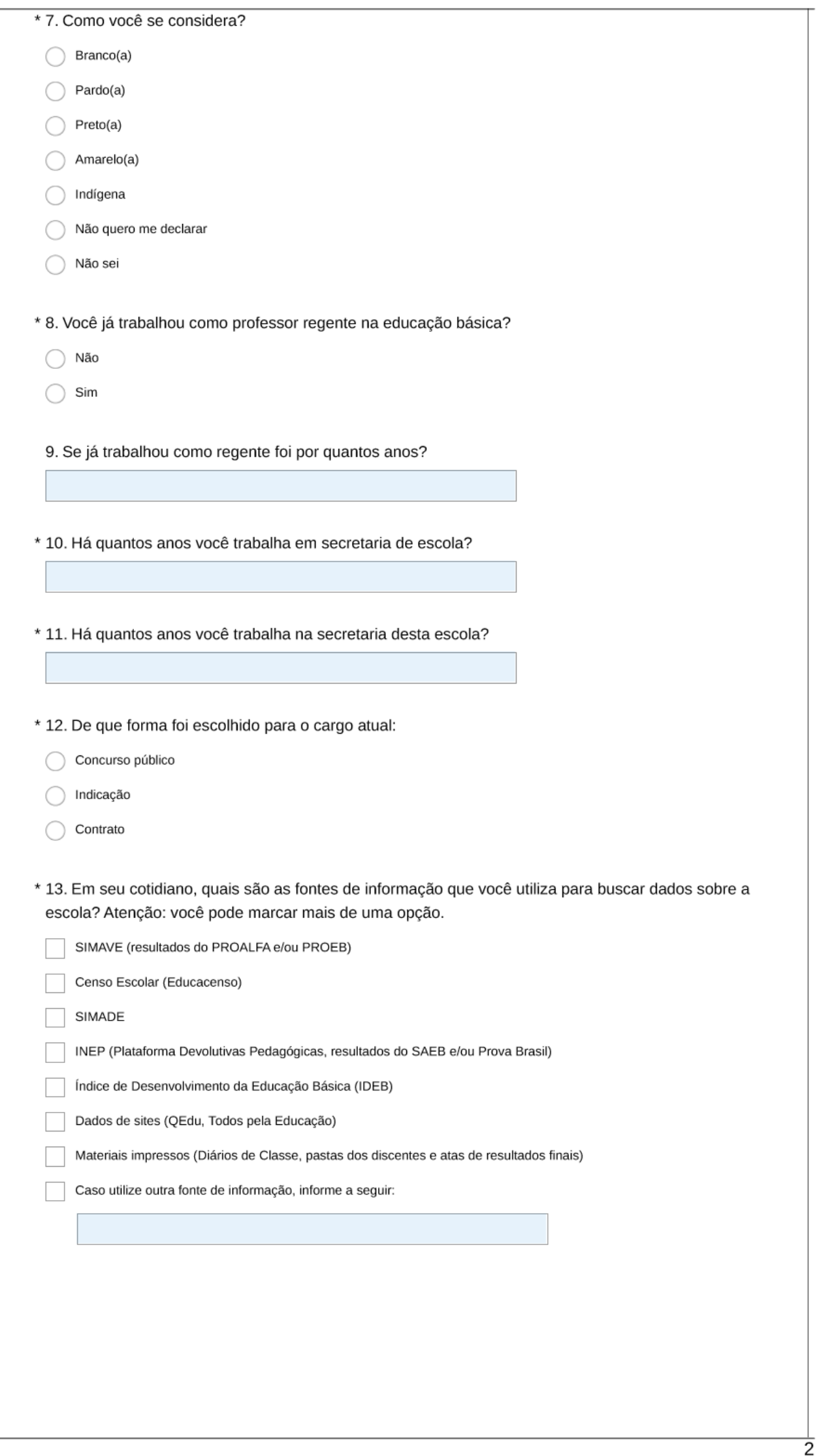


* 14. Quais são as condições de uso dos recursos de informática da escola?

$\begin{gathered}\text { Bom estado de } \\ \text { conservação }\end{gathered}$
$\begin{aligned} & \text { Computadores para uso } \\ & \text { exclusivo da equipe de } \\ & \text { gestão (diretor e vice- } \\ & \text { diretor) }\end{aligned}$
$\begin{aligned} & \text { Computadores para uso } \\ & \text { exclusivo da equipe da } \\ & \text { secretaria da escola }\end{aligned}$
$\begin{aligned} & \text { Computadores para uso } \\ & \text { exclusivo da Sala dos } \\ & \text { professores }\end{aligned}$
$\begin{aligned} & \text { Computadores para uso } \\ & \text { exclusivo da Sala da } \\ & \text { supervisão }\end{aligned}$
Computador portátil
(notebook, laptop,
netbook, tablet)

* 15. Entre as alternativas abaixo, informe se a escola participa de algum programa ou projeto:

Programa Nacional de
Tecnologia Educacional
(Prolnfo Integrado)
Projeto Escolas em
Rede
Programa Banda Larga
nas Escolas (PBLE)
Programa Um
Computador por Aluno
(PROUCA)

* 16. Como você define seu nível de conhecimento para utilizar....

\begin{tabular}{|c|c|c|c|c|}
\hline & Não sei opinar & Iniciante & Intermediário & Avançado \\
\hline \multicolumn{5}{|l|}{ Email } \\
\hline \multicolumn{5}{|c|}{$\begin{array}{l}\text { Editores de texto (Word, } \\
\text { BrOffice, etc.) }\end{array}$} \\
\hline \multicolumn{5}{|c|}{$\begin{array}{l}\text { Planilhas eletrônicas } \\
\text { (Excel, Open Office, } \\
\text { BrOffice) }\end{array}$} \\
\hline \multicolumn{5}{|c|}{$\begin{array}{l}\text { O Internet Explorer, } \\
\text { Mozila Firefox, Chrome, } \\
\text { etc. }\end{array}$} \\
\hline O SIMADE & & & & \\
\hline
\end{tabular}




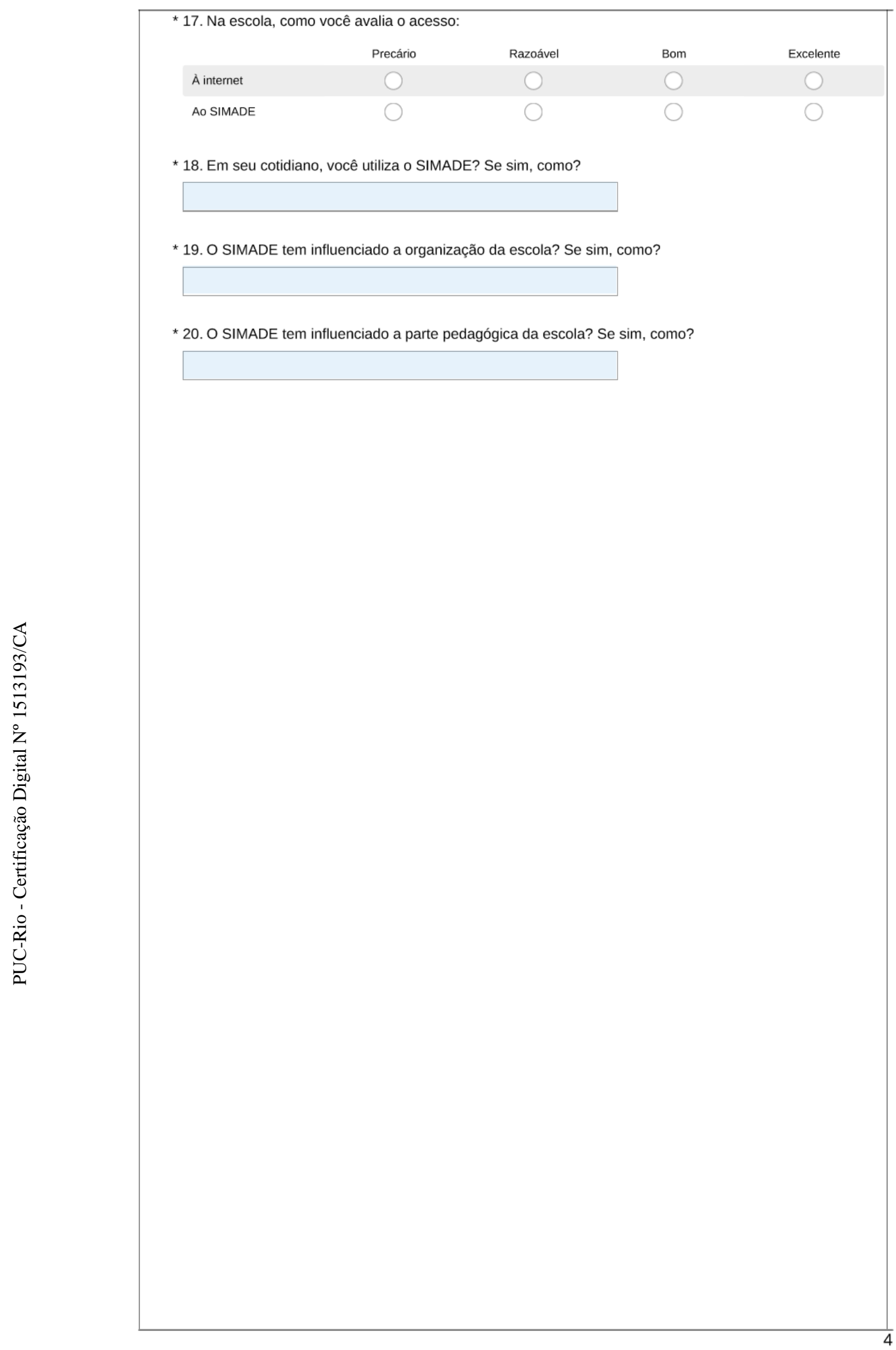




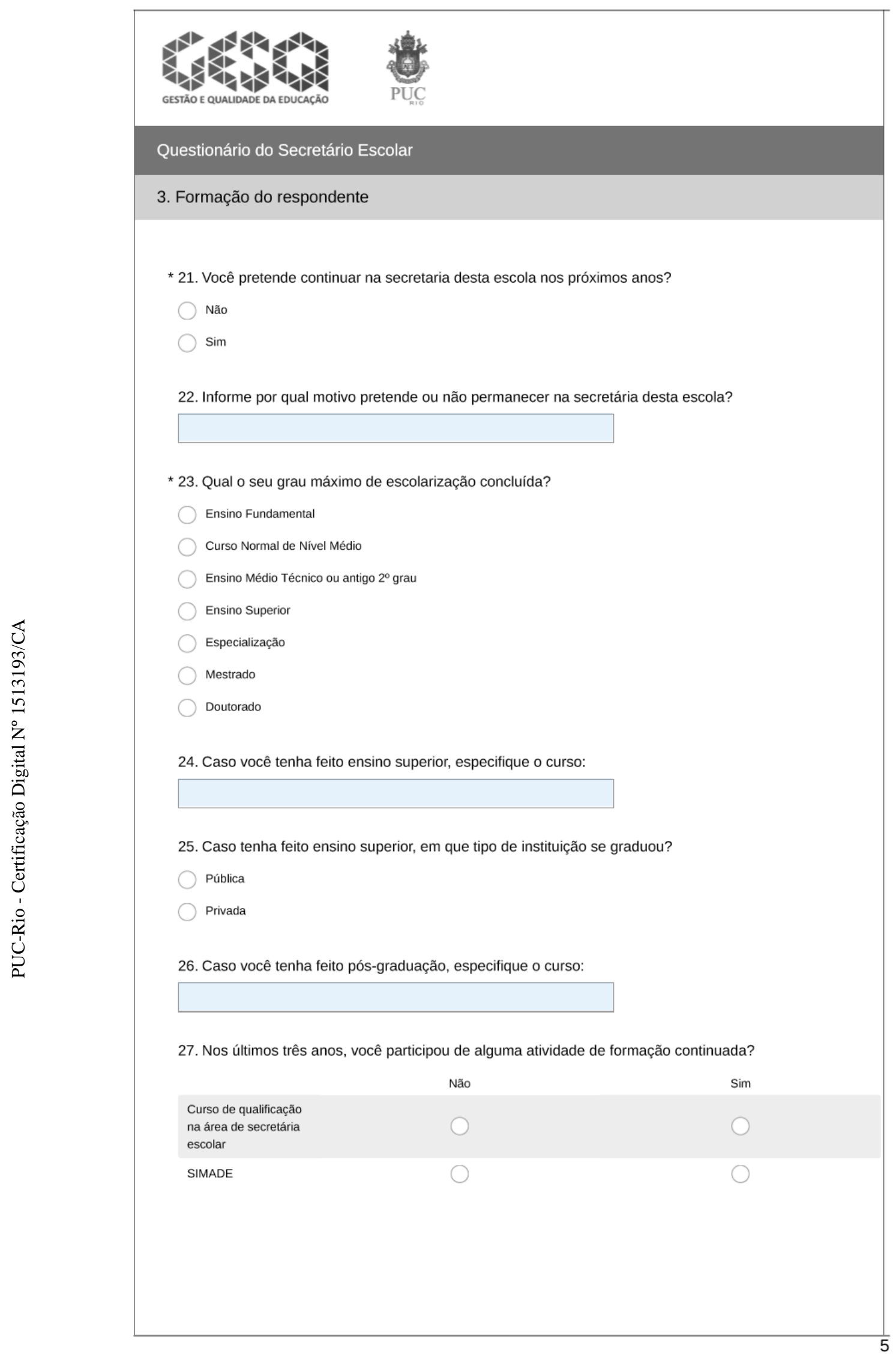




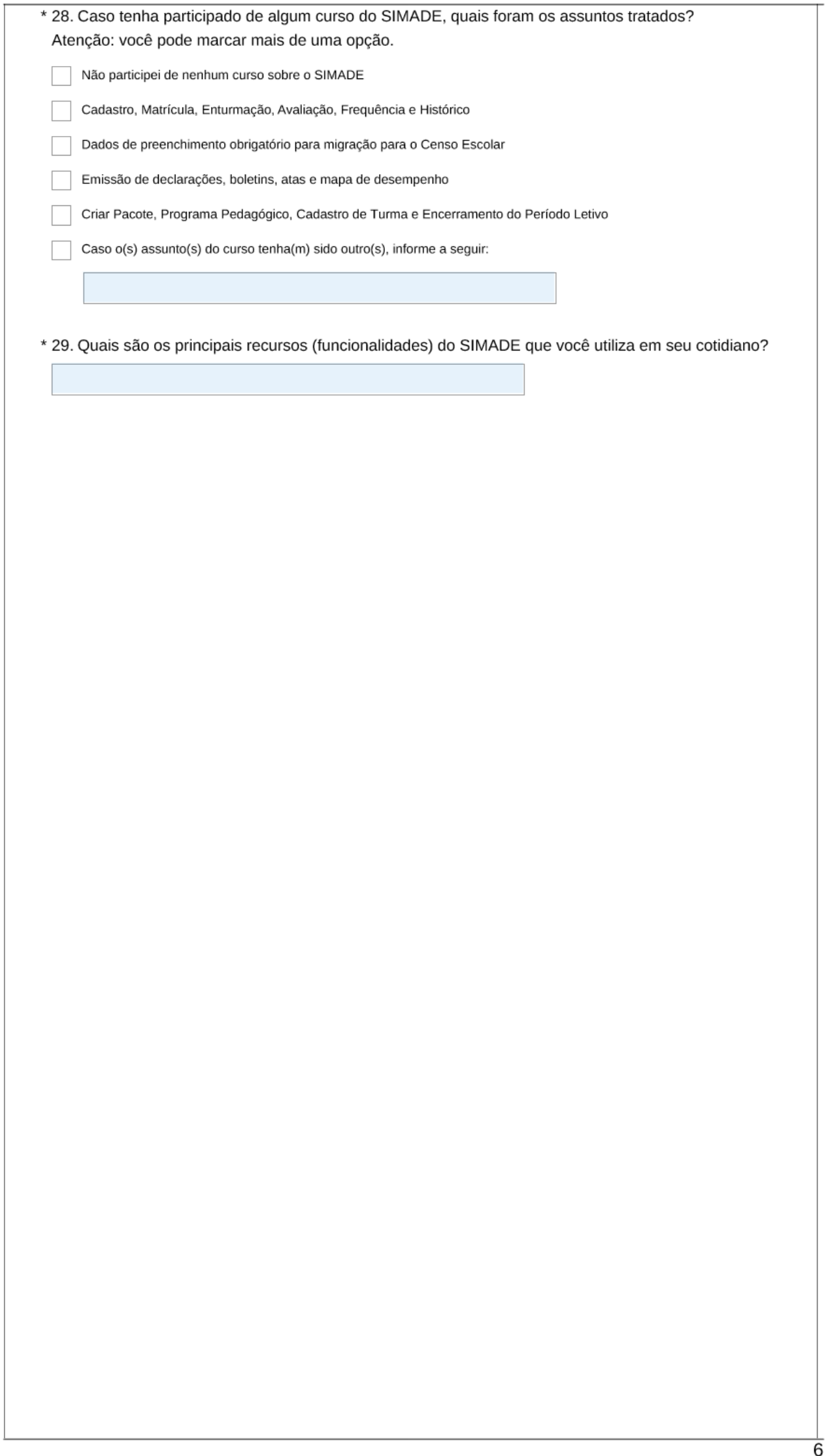


* 30. Sobre o seu trabalho nesta escola, marque qual é o seu nível de concordância com cada uma das afirmativas abaixo:

\begin{tabular}{|c|c|c|c|c|}
\hline & Discordo totalmente & Discordo em parte & Concordo em parte & Concordo totalmente \\
\hline \multicolumn{5}{|l|}{$\begin{array}{l}\text { Sinto-me satisfeito com } \\
\text { as relaçб̃es } \\
\text { estabelecidas no meu } \\
\text { local de trabalho }\end{array}$} \\
\hline \multicolumn{5}{|l|}{$\begin{array}{l}\text { Sinto-me estressado (a) } \\
\text { com o volume de } \\
\text { demandas que o } \\
\text { trabalho da secretaria } \\
\text { escolar me exige }\end{array}$} \\
\hline \multicolumn{5}{|l|}{$\begin{array}{l}\text { Divido responsabilidades } \\
\text { do SIMADE com a } \\
\text { direção da escola }\end{array}$} \\
\hline \multicolumn{5}{|l|}{$\begin{array}{l}\text { O planejamento anual } \\
\text { das atividades é } \\
\text { elaborado com a } \\
\text { participação dos } \\
\text { professores e demais } \\
\text { profissionais da escola }\end{array}$} \\
\hline \multicolumn{5}{|l|}{$\begin{array}{l}\text { Para tomar decisões o } \\
\text { diretor ouve os } \\
\text { profissionais da escola }\end{array}$} \\
\hline \multicolumn{5}{|l|}{$\begin{array}{l}\text { Sinto-me respeitado(a) } \\
\text { pelo diretor }\end{array}$} \\
\hline \multicolumn{5}{|l|}{$\begin{array}{l}\text { Participo das decisões } \\
\text { relacionadas ao meu } \\
\text { trabalho }\end{array}$} \\
\hline \multicolumn{5}{|l|}{$\begin{array}{l}\text { Tenho confiança no } \\
\text { diretor(a) como } \\
\text { profissional }\end{array}$} \\
\hline $\begin{array}{l}\text { A direção leva em } \\
\text { consideração minhas } \\
\text { ideias }\end{array}$ & & & & \\
\hline $\begin{array}{l}\text { O diretor é exigente no } \\
\text { cumprimento das tarefas }\end{array}$ & & & & \\
\hline
\end{tabular}




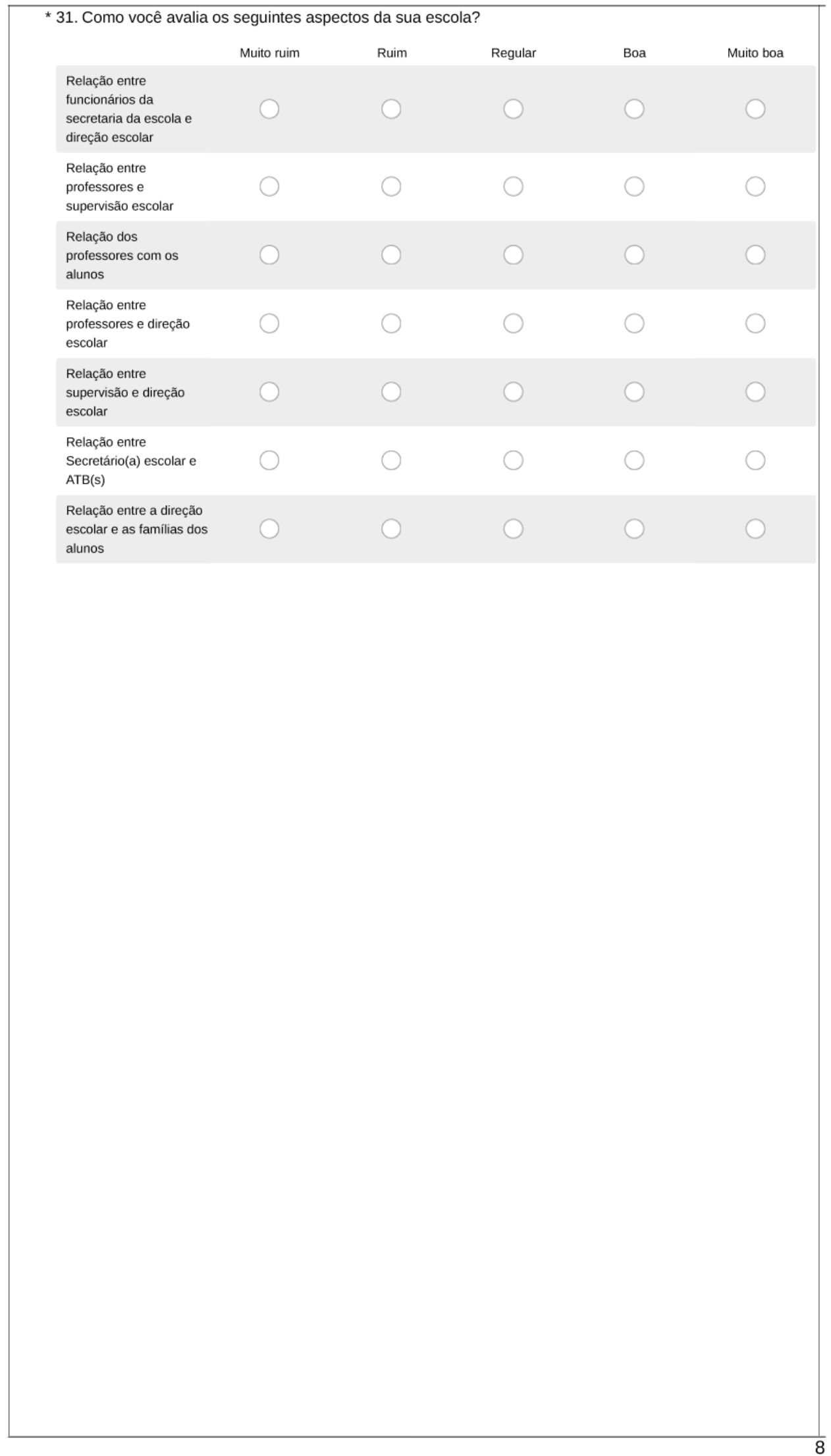




\section{0 \\ GESTÃO E QUALIDADE DA EDUCAC̆̃̃́}

GESTAOO E QUALD

Questionário do Secretário Escolar

5. SIMADE na secretaria da escola

* 32. Você considera que os dados do SIMADE são úteis para: Atenção: você pode marcar mais de uma resposta.

Planejar as metas e os objetivos da escola

Orientar a distribuição de alunos entre as turmas

Orientar a distribuição de professores entre as turmas

Orientar a organização dos horários escolares

Planejar atividades extracurriculares na escola

Melhorar o desempenho dos alunos

Organizar as reuniões pedagógicas com os professores

Conversar com os professores sobre o desempenho dos alunos

Criar estratégias para diminuir a evasão escolar

Criar estratégias para diminuir a reprovação

Criar estratégias de reforço para alunos com dificuldades

Caso considere os dados do SIMADE úteis para outra ação/atividade, informe a seguir:

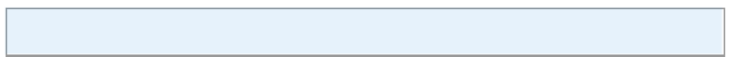

* 33. Do seu ponto de vista, qual a contribuição mais importante que o SIMADE oferece para o seu trabalho na escola?

Não sei opinar

Gestão administrativa da escola

Gestão pedagógica da escola

Gestão administrativa e pedagógica da escola 
* 34. Indique com que frequência você utiliza os dado do SIMADE para:

\begin{tabular}{|c|c|c|c|c|c|}
\hline & Nunca & Uma vez por ano & $\begin{array}{c}\text { De } 3 \text { a } 4 \text { vezes ao } \\
\text { ano }\end{array}$ & Mensalmente & Semanalmente \\
\hline \multicolumn{6}{|c|}{$\begin{array}{l}\text { Elaborar relatórios e } \\
\text { ofícios para a direção da } \\
\text { escola }\end{array}$} \\
\hline \multicolumn{6}{|l|}{$\begin{array}{l}\text { Elaborar relatórios e } \\
\text { ofícios para a SRE }\end{array}$} \\
\hline \multicolumn{6}{|c|}{$\begin{array}{l}\text { Fornecer declarações, } \\
\text { transferências e } \\
\text { históricos para pais ou } \\
\text { alunos }\end{array}$} \\
\hline \multicolumn{6}{|l|}{$\begin{array}{l}\text { Verificar alunos que } \\
\text { necessitam de } \\
\text { condução escolar }\end{array}$} \\
\hline $\begin{array}{l}\text { Verificar evasão e } \\
\text { abandono discente }\end{array}$ & & & & & \\
\hline
\end{tabular}

* 35. Com que frequência você acessa o SIMADE?

Nunca

Entre 1 e três vezes por mês

1 vez por semana

2 vezes por semana

3 vezes por semana

4 vezes por semana

Todos os dias

* 36. Qual a sua responsabilidade em relação ao SIMADE?

* 37. Considerando o seu trabalho na escola, marque qual é o seu nível de concordância com cada uma das afirmativas abaixo:

Considero a utilização
do SIMADE bastante
fácil
Utilizar o SIMADE é algo
de que raramente gosto
Estou bastante
confiante na minha
capacidade para utilizar
o SIMADE
O SIMADE me ajuda a
poupar tempo na
realização de minhas
atividades


* 38. Marque qual é o seu nível de concordância com cada uma das alternativas abaixo sobre o SIMADE:

\begin{tabular}{|c|c|c|c|c|}
\hline & Discordo totalmente & Discordo em parte & Concordo em parte & Concordo totalmente \\
\hline \multicolumn{5}{|l|}{$\begin{array}{l}\text { O SIMADE tem uma } \\
\text { apresentação agradável }\end{array}$} \\
\hline \multicolumn{5}{|l|}{$\begin{array}{l}\text { A forma e o tamanho das } \\
\text { letras são adequados }\end{array}$} \\
\hline \multicolumn{5}{|l|}{$\begin{array}{l}\text { Os ícones/botões são } \\
\text { fáceis de utilizar }\end{array}$} \\
\hline \multicolumn{5}{|l|}{$\begin{array}{l}\text { Encontro as } \\
\text { informaçōes com } \\
\text { facilidade }\end{array}$} \\
\hline \multicolumn{5}{|l|}{$\begin{array}{l}\text { Os textos do SIMADE } \\
\text { são claros e objetivos }\end{array}$} \\
\hline \multicolumn{5}{|l|}{$\begin{array}{l}\text { Tenho dificuldade de } \\
\text { salvar informações no } \\
\text { SIMADE }\end{array}$} \\
\hline \multicolumn{5}{|l|}{$\begin{array}{l}\text { Em geral, o SIMADE } \\
\text { executa as tarefas } \\
\text { rapidamente }\end{array}$} \\
\hline \multicolumn{5}{|l|}{$\begin{array}{l}\text { As mensagens de erro } \\
\text { do SIMADE são claras }\end{array}$} \\
\hline \multicolumn{5}{|l|}{$\begin{array}{l}\text { As mensagens de erro } \\
\text { do SIMADE ajudam a } \\
\text { solucionar os problemas }\end{array}$} \\
\hline \multicolumn{5}{|l|}{ Confio no SIMADE } \\
\hline \multicolumn{5}{|l|}{$\begin{array}{l}\text { As funcionalidades do } \\
\text { SIMADE satisfazem } \\
\text { totalmente minhas } \\
\text { necessidades } \\
\text { profissionais }\end{array}$} \\
\hline \multicolumn{5}{|l|}{$\begin{array}{l}\text { A interface do } \\
\text { sistema(menus) permite } \\
\text { que alcance meus } \\
\text { objetivos facilmente }\end{array}$} \\
\hline \multicolumn{5}{|l|}{$\begin{array}{l}\text { Estou satisfeito com o } \\
\text { funcionamento do } \\
\text { SIMADE }\end{array}$} \\
\hline \multicolumn{5}{|l|}{$\begin{array}{l}\text { É fácil aprender como } \\
\text { funciona o SIMADE }\end{array}$} \\
\hline $\begin{array}{l}\text { O sistema não } \\
\text { apresenta erros nem } \\
\text { interrupções na sua } \\
\text { execução }\end{array}$ & & & & \\
\hline
\end{tabular}




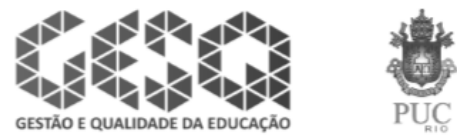

Questionário do Secretário Escolar

6. O SIMADE na gestão da escola

* 39. O diretor acessa o SIMADE?

ก Não

Sim

40. Caso tenha respondido Sim na pergunta anterior, informe para queo diretor acessa ao SIMADE.

* 41. O diretor solicita os dados do SIMADE nas:

Reuniões pedagógicas
Conversas e/ou reunião
com os pais
Transmissões de
informações para a SRE
Visitas do(a) inspetor(a)
escolar

* 42. Em uma semana, quantas horaso diretor dedica para:

\begin{tabular}{|c|c|c|c|c|c|c|}
\hline & Não se aplica & $\begin{array}{c}\text { Entre } 1 \text { e } 5 \\
\text { horas }\end{array}$ & De 6 a 10 horas & $\begin{array}{c}\text { De } 11 \text { a } 20 \\
\text { horas }\end{array}$ & $\begin{array}{c}\text { De } 21 \text { a } 30 \\
\text { horas }\end{array}$ & $\begin{array}{c}\text { Mais de } 30 \\
\text { horas }\end{array}$ \\
\hline $\begin{array}{l}\text { Gestão de pessoal } \\
\text { (administração das relações } \\
\text { entre professores e entre } \\
\text { funcionários, controle de } \\
\text { faltas e licenças) }\end{array}$ & & & & & & \\
\hline $\begin{array}{l}\text { Gestão administrativa } \\
\text { (prestação de contas, } \\
\text { coleta de orçamentos, } \\
\text { organização de horários, } \\
\text { controles financeiros) }\end{array}$ & & & & & & \\
\hline $\begin{array}{l}\text { Aspectos pedagógicos } \\
\text { (discussões sobre o } \\
\text { currículo, metodologia de } \\
\text { ensino, análise de } \\
\text { desempenho e disciplina e } \\
\text { comportamento dos alunos) }\end{array}$ & & & & & & \\
\hline $\begin{array}{l}\text { Relações externas } \\
\text { (atendimento aos pais, } \\
\text { reunióes na SRE, } \\
\text { organização/monitoramento } \\
\text { de parcerias) }\end{array}$ & & & & & & \\
\hline
\end{tabular}


* 43. Indique com que frequência você realiza as seguintes atividades no seu trabalho na secretaria da escola:

\begin{tabular}{|c|c|c|c|c|}
\hline & Nunca & Raramente & Algumas vezes & Frequentemente \\
\hline $\begin{array}{l}\text { Ler as legislaçōes e } \\
\text { orientações } \\
\text { educacionais da } \\
\text { SEE/MG }\end{array}$ & & & & \\
\hline Ler os emails da escola & & & & \\
\hline $\begin{array}{l}\text { Organizar a } \\
\text { documentação dos } \\
\text { alunos em armários, } \\
\text { gavetas, etc. }\end{array}$ & & & & \\
\hline Atender pais & & & & \\
\hline $\begin{array}{l}\text { Atender o supervisor } \\
\text { escolar }\end{array}$ & & & & \\
\hline $\begin{array}{l}\text { Assegurar que os dados } \\
\text { dos alunos estejam } \\
\text { corretos para a } \\
\text { migração para o Censo } \\
\text { Escolar (Educacenso) }\end{array}$ & & & & \\
\hline $\begin{array}{l}\text { Distribuir o serviço da } \\
\text { secretaria entre a } \\
\text { equipe de Assistentes } \\
\text { Técnicos da Educação } \\
\text { Básica (ATBs) }\end{array}$ & & & & \\
\hline $\begin{array}{l}\text { Tirar dúvidas e resolver } \\
\text { pendências com a } \\
\text { equipe do SEDINE }\end{array}$ & & & & \\
\hline $\begin{array}{l}\text { Tomar decisões em } \\
\text { relação a secretaria } \\
\text { junto com o diretor(a) }\end{array}$ & & & & \\
\hline
\end{tabular}

44. Caso queira registrar algum comentário sobre este questionário ou acrescentar alguma informação que julgue importante, utilize o espaço abaixo. 


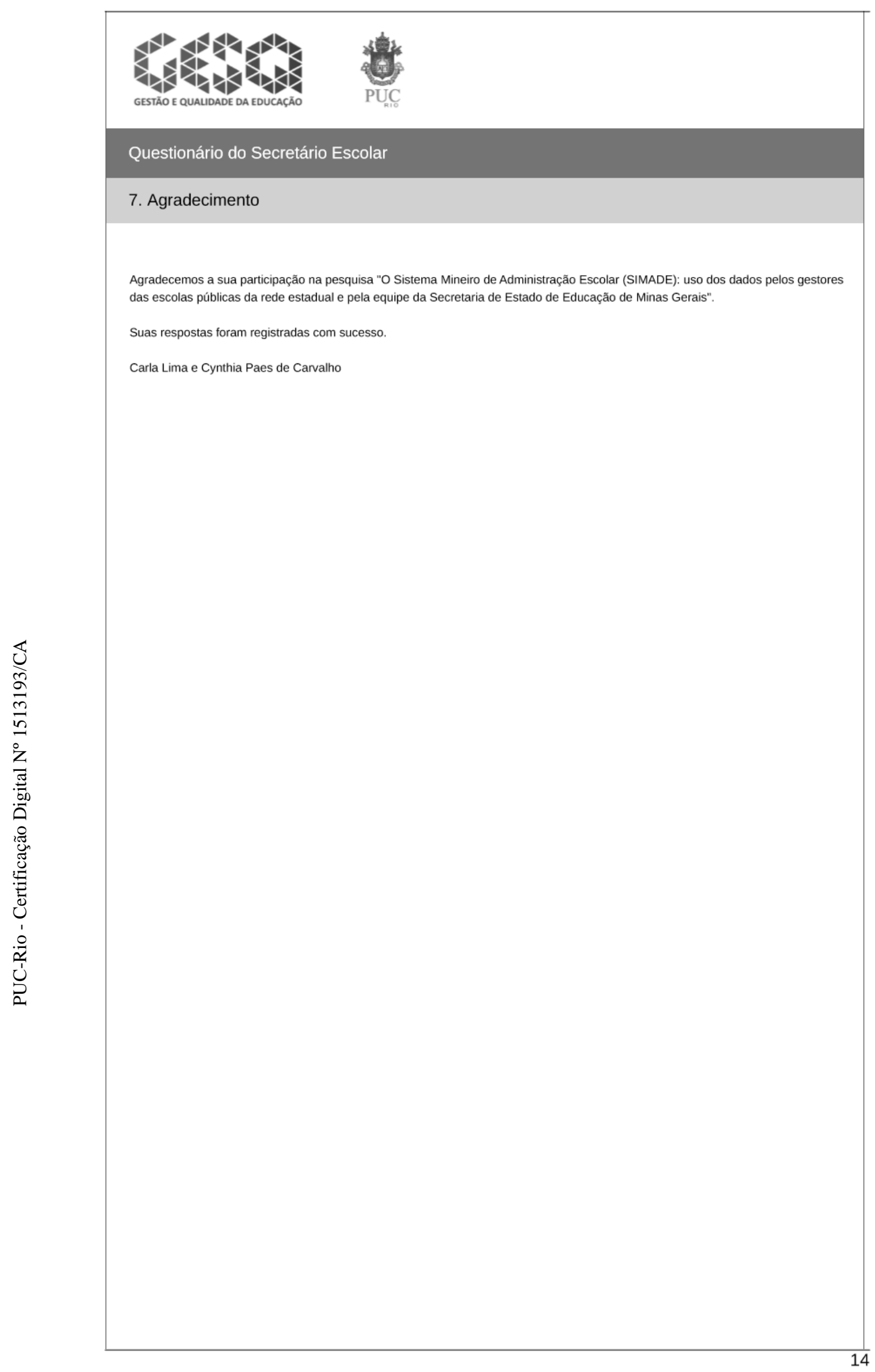




\section{Anexo 5:}

Quadros com conceitos latentes e observáveis dos questionários de secretário e diretor escolar

Quadro I - Quadro de Referência Conceitual para a operacionalização de itens do questionário da Equipe da Secretaria da Escola

\begin{tabular}{|c|c|c|}
\hline Conceitos & Conceitos secundários & Classificação \\
\hline & Nome & Observável \\
\hline Escola & Código & Observável \\
\hline \multirow{11}{*}{ Infraestrutura } & Computadores para uso da equipe de gestão & Observável \\
\hline & Computadores para uso da equipe da secretaria da escola & Observável \\
\hline & Computador para uso dos professores & Observável \\
\hline & Computador para uso da supervisão & Observável \\
\hline & Computador portátil & Observável \\
\hline & Acesso à internet & Observável \\
\hline & Acesso ao SIMADE & Observável \\
\hline & PROINFO Integrado & Observável \\
\hline & Projeto Escolas em Rede & Observável \\
\hline & Projeto Banda Larga na Escola & Observável \\
\hline & PROUCA & Observável \\
\hline \multirow{10}{*}{ 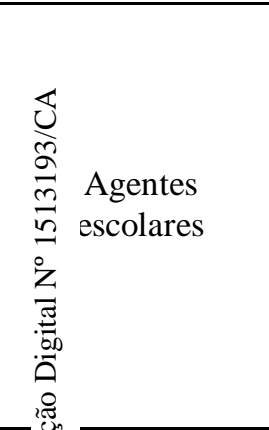 } & Cargo & Observável \\
\hline & Sexo & Observável \\
\hline & Idade & Observável \\
\hline & Cor/Raça & Observável \\
\hline & Pretende continuar na secretaria desta escola & Observável \\
\hline & Formação acadêmica & Observável \\
\hline & Tempo na docência & Observável \\
\hline & Experiência na função na secretaria de escola & Observável \\
\hline & Tempo na função nesta escola & Observável \\
\hline & Provimento do cargo & Observável \\
\hline \multirow{7}{*}{ 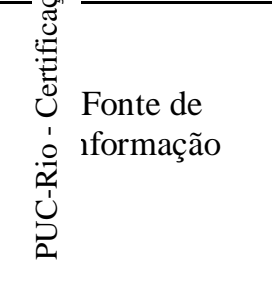 } & SIMAVE & Observável \\
\hline & Censo Escolar & Observável \\
\hline & SIMADE & Observável \\
\hline & INEP & Observável \\
\hline & IDEB & Observável \\
\hline & Dados de sites & Observável \\
\hline & Materiais impressos & Observável \\
\hline \multirow{5}{*}{$\begin{array}{l}\text { Autoeficácia } \\
\text { computacional }\end{array}$} & Email & Observável \\
\hline & Editores de texto & Observável \\
\hline & Planilhas eletrônicas & Observável \\
\hline & Internet Explores, Mozila Firefox, Chrome & Observável \\
\hline & SIMADE & Observável \\
\hline \multirow{12}{*}{ Uso do SIMADE } & Utiliza o SIMADE & Observável \\
\hline & O SIMADE influencia na organização da escola & Observável \\
\hline & O SIMADE influencia na parte pedagógica da escola & Observável \\
\hline & Contribuição do SIMADE para o trabalho & Observável \\
\hline & Frequência de acesso ao SIMADE & Observável \\
\hline & Responsabilidade em relação ao SIMADE & Observável \\
\hline & Facilidade de utilização do SIMADE bastante fácil & Observável \\
\hline & Utilizar percepção sobre o SIMADE & Observável \\
\hline & Capacidade de utilizar o SIMADE & Observável \\
\hline & SIMADE agiliza a realização das tarefas & Observável \\
\hline & O diretor acessa o SIMADE & Observável \\
\hline & Para que o diretor acessa o SIMADE & Observável \\
\hline
\end{tabular}




\begin{tabular}{|c|c|c|}
\hline Conceitos & Conceitos secundários & Classificação \\
\hline & Reuniões pedagógicas & Observável \\
\hline & Conversas e/ou reunião com os pais & Observável \\
\hline & Transmissões de informações para a SRE & Observável \\
\hline & Visitas do(a) inspetor(a) escolar & Observável \\
\hline \multirow{6}{*}{$\begin{array}{l}\text { Formação } \\
\text { continuada }\end{array}$} & Curso de qualificação na área de secretaria escolar & Observável \\
\hline & Curso sobre SIMADE & Observável \\
\hline & Cadastro, matrícula, enturmação, avaliação, frequência e histórico & Observável \\
\hline & Dados de preenchimento obrigatório para migração para o Censo Escolar & Observável \\
\hline & Emissão de declarações, boletins, atas e mapas de desempenho & Observável \\
\hline & $\begin{array}{l}\text { Criar pacote, programa pedagógico, cadastro de turma e encerramento do } \\
\text { período letivo }\end{array}$ & Observável \\
\hline \multirow{12}{*}{$\begin{array}{l}\text { Uso dos dados do } \\
\text { SIMADE }\end{array}$} & Principais recursos (funcionalidades) do SIMADE & Observável \\
\hline & Planejar as metas e os objetivos da escola & Observável \\
\hline & Orientar a distribuição de alunos entre as turmas & Observável \\
\hline & Orientar a distribuição de professores entre as turmas & Observável \\
\hline & Orientar a organização dos horários escolares & Observável \\
\hline & Planejar atividades extracurriculares na escola & Observável \\
\hline & Melhorar o desempenho dos alunos & Observável \\
\hline & Organizar reuniões pedagógicas com os professores & Observável \\
\hline & Conversar com os professores sobre o desempenho dos alunos & Observável \\
\hline & Criar estratégias para diminuir a evasão escolar & Observável \\
\hline & Criar estratégias para diminuir a reprovação escolar & Observável \\
\hline & Criar estratégias de reforço para alunos com dificuldades & Observável \\
\hline \multirow{13}{*}{ 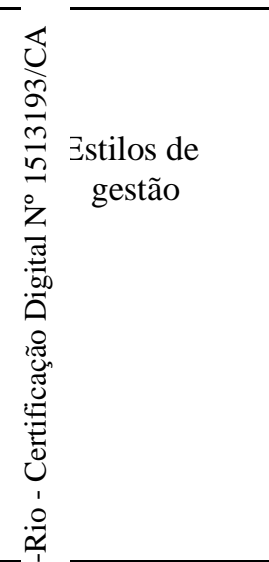 } & Satisfação com as relações estabelecidas no trabalho & Observável \\
\hline & Estresse com o volume de demandas do trabalho & Latente \\
\hline & Divido responsabilidades do SIMADE & Latente \\
\hline & Planejamento anual das atividades & Latente \\
\hline & Participação nas decisões & Latente \\
\hline & Respeito entre os profissionais da escola & Latente \\
\hline & Confiança entre os profissionais & Latente \\
\hline & Compartilhamento de ideias & Latente \\
\hline & Exigência no cumprimento das tarefas & Latente \\
\hline & Gestão de pessoal & Observável \\
\hline & Gestão administrativa & Observável \\
\hline & Aspectos pedagógicos & Observável \\
\hline & Relações externas & Observável \\
\hline \multirow{7}{*}{ ima escola } & Relações entre funcionários da secretaria da escola e direção escolar & Observável \\
\hline & Relação entre professores e supervisão escolar & Observável \\
\hline & Relação dos professores com os alunos & Observável \\
\hline & Relação entre professores e direção escolar & Observável \\
\hline & Relação entre supervisão e direção escolar & Observável \\
\hline & Relação entre secretário(a) escolar e ATB(s) & Observável \\
\hline & Relação entre a direção escolar e as famílias dos alunos & Observável \\
\hline \multirow{13}{*}{$\begin{array}{l}\text { Atividades da } \\
\text { função }\end{array}$} & Elaborar relatórios e ofícios & Observável \\
\hline & Declarações, transferências e históricos para pais ou alunos & Observável \\
\hline & Condução escolar & Observável \\
\hline & Evasão e abandono discente & Observável \\
\hline & Legislações e orientações educacionais & Observável \\
\hline & Emails da escola & Observável \\
\hline & Organizar a documentação dos alunos & Observável \\
\hline & Atender os pais & Observável \\
\hline & Atender o supervisor escolar & Observável \\
\hline & Dados corretos & Observável \\
\hline & Organização da secretaria escolar & Observável \\
\hline & Comunicação entre escola e SRE & Observável \\
\hline & Compartilhar decisões com o diretor & Observável \\
\hline
\end{tabular}




\begin{tabular}{|c|c|c|}
\hline Conceitos & Conceitos secundários & Classificação \\
\hline \multirow{15}{*}{$\begin{array}{l}\text { Usabilidade do } \\
\text { SIMADE }\end{array}$} & O SIMADE tem uma apresentação agradável & Observável \\
\hline & A forma e o tamanho das letras são adequados & Observável \\
\hline & Os ícones/botões são fáceis de utilizar & Observável \\
\hline & Encontro as informações com facilidade & Observável \\
\hline & Os textos do SIMADE são claros e objetivos & Observável \\
\hline & Tenho dificuldade de salvar informações no SIMADE & Observável \\
\hline & Em geral, o SIMADE executa as tarefas rapidamente & Observável \\
\hline & As mensagens de erro do SIMADE são claras. & Observável \\
\hline & As mensagens de erro do SIMADE ajudam a solucionar os problemas. & Observável \\
\hline & Confio no SIMADE & Observável \\
\hline & $\begin{array}{l}\text { As funcionalidades do SIMADE satisfazem totalmente minhas necessidades } \\
\text { profissionais }\end{array}$ & Observável \\
\hline & $\begin{array}{l}\text { A interface do sistema (menus) permite que alcance meus objetivos } \\
\text { facilmente }\end{array}$ & Observável \\
\hline & Estou satisfeito com o funcionamento do SIMADE & Observável \\
\hline & É fácil aprender como funciona o SIMADE & Observável \\
\hline & O sistema não apresenta erros nem interrupções na sua execução & Observável \\
\hline
\end{tabular}

Quadro II Quadro de Referência Conceitual para a operacionalização de itens do questionário do Diretor da Escola

\begin{tabular}{|c|c|c|}
\hline Conceitos & Conceitos secundários & Classificação \\
\hline \multirow{18}{*}{ 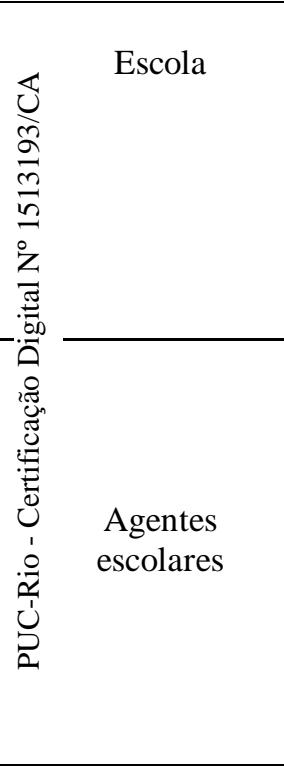 } & Nome & Observável \\
\hline & Código & Observável \\
\hline & Acesso à internet & Observável \\
\hline & Acesso ao SIMADE & Observável \\
\hline & PROINFO Integrado & Observável \\
\hline & Projeto Escolas em Rede & Observável \\
\hline & Projeto Banda Larga na Escola & Observável \\
\hline & PROUCA & Observável \\
\hline & Cargo & Observável \\
\hline & Sexo & Observável \\
\hline & Idade & Observável \\
\hline & Cor/Raça & Observável \\
\hline & Pretende continuar na direção desta escola & Observável \\
\hline & Formação acadêmica & Observável \\
\hline & Tempo na docência & Observável \\
\hline & Experiência na função na direção da escola & Observável \\
\hline & Tempo na função nesta escola & Observável \\
\hline & Provimento do cargo & Observável \\
\hline \multirow{6}{*}{$\begin{array}{c}\text { Autoeficácia do } \\
\text { diretor }\end{array}$} & Atividades do seu trabalho & Latente \\
\hline & Resolver problemas burocráticos & Latente \\
\hline & Apoiar atividades pedagógicas & Latente \\
\hline & Elevar o desempenho dos alunos no SIMAVE & Latente \\
\hline & Usar o SIMADE em aspectos pedagógicos & Latente \\
\hline & Usar o SIMADE em aspectos administrativos & Latente \\
\hline \multirow{7}{*}{$\begin{array}{c}\text { Fonte de } \\
\text { informação }\end{array}$} & SIMAVE & Observável \\
\hline & Censo Escolar & Observável \\
\hline & SIMADE & Observável \\
\hline & INEP & Observável \\
\hline & IDEB & Observável \\
\hline & Dados de sites & Observável \\
\hline & Materiais impressos & Observável \\
\hline \multirow{3}{*}{$\begin{array}{l}\text { Autoeficácia } \\
\text { computacional }\end{array}$} & Email & Observável \\
\hline & Editores de texto & Observável \\
\hline & Planilhas eletrônicas & Observável \\
\hline
\end{tabular}




\begin{tabular}{|c|c|c|}
\hline Conceitos & Conceitos secundários & Classificação \\
\hline & Internet Explores, Mozila Firefox, Chrome & Observável \\
\hline & SIMADE & Observável \\
\hline \multirow{16}{*}{ Uso do SIMADE } & Utiliza o SIMADE & Observável \\
\hline & O SIMADE influencia na organização da escola & Observável \\
\hline & O SIMADE influencia na parte pedagógica da escola & Observável \\
\hline & Contribuição do SIMADE para o trabalho & Observável \\
\hline & Frequência de acesso ao SIMADE & Observável \\
\hline & Responsabilidade em relação ao SIMADE & Observável \\
\hline & Facilidade de utilização do SIMADE bastante fácil & Observável \\
\hline & Utilizar percepção sobre o SIMADE & Observável \\
\hline & Capacidade de utilizar o SIMADE & Observável \\
\hline & SIMADE agiliza a realização das tarefas & Observável \\
\hline & O diretor acessa o SIMADE & Observável \\
\hline & Para que o diretor acessa o SIMADE & Observável \\
\hline & Reuniões pedagógicas & Observável \\
\hline & Conversas e/ou reunião com os pais & Observável \\
\hline & Transmissões de informações para a SRE & Observável \\
\hline & Visitas do(a) inspetor(a) escolar & Observável \\
\hline \multirow{19}{*}{ 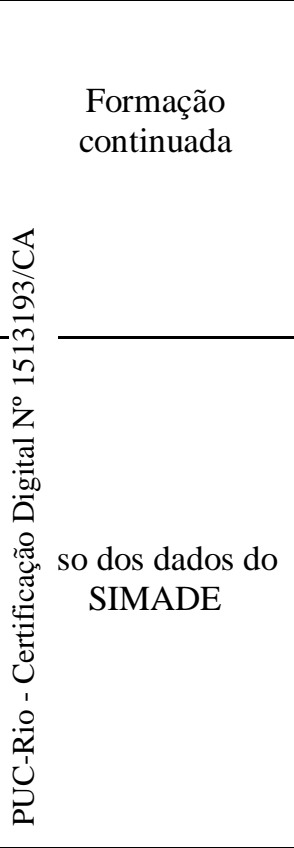 } & Curso de qualificação na área de gestão escolar/educacional & Observável \\
\hline & Curso sobre SIMADE & Observável \\
\hline & Curso de Apropriação de resultados & Observação \\
\hline & Cadastro, matrícula, enturmação, avaliação, frequência e histórico & Observável \\
\hline & Dados de preenchimento obrigatório para migração para o Censo Escolar & Observável \\
\hline & Emissão de declarações, boletins, atas e mapas de desempenho & Observável \\
\hline & $\begin{array}{l}\text { Criar pacote, programa pedagógico, cadastro de turma e encerramento do } \\
\text { período letivo }\end{array}$ & Observável \\
\hline & Principais recursos (funcionalidades) do SIMADE & Observável \\
\hline & Planejar as metas e os objetivos da escola & Observável \\
\hline & Orientar a distribuição de alunos entre as turmas & Observável \\
\hline & Orientar a distribuição de professores entre as turmas & Observável \\
\hline & Orientar a organização dos horários escolares & Observável \\
\hline & Planejar atividades extracurriculares na escola & Observável \\
\hline & Melhorar o desempenho dos alunos & Observável \\
\hline & Organizar reuniões pedagógicas com os professores & Observável \\
\hline & Conversar com os professores sobre o desempenho dos alunos & Observável \\
\hline & Criar estratégias para diminuir a evasão escolar & Observável \\
\hline & Criar estratégias para diminuir a reprovação escolar & Observável \\
\hline & Criar estratégias de reforço para alunos com dificuldades & Observável \\
\hline \multirow{11}{*}{$\begin{array}{l}\text { Estilos de } \\
\text { gestão }\end{array}$} & Satisfação com as relações estabelecidas no trabalho & Observável \\
\hline & Estresse com o volume de demandas do trabalho & Latente \\
\hline & Divido responsabilidades do SIMADE & Latente \\
\hline & Planejamento anual das atividades & Latente \\
\hline & Participação nas decisões & Latente \\
\hline & Recursos financeiros & Latente \\
\hline & Projetos SRE e SEE/MG & Latente \\
\hline & Gestão de pessoal & Observável \\
\hline & Gestão administrativa & Observável \\
\hline & Aspectos pedagógicos & Observável \\
\hline & Relações externas & Observável \\
\hline \multirow[t]{7}{*}{ Clima escola } & Relações entre funcionários da secretaria da escola e direção escolar & Observável \\
\hline & Relação entre professores e supervisão escolar & Observável \\
\hline & Relação dos professores com os alunos & Observável \\
\hline & Relação entre professores e direção escolar & Observável \\
\hline & Relação entre supervisão e direção escolar & Observável \\
\hline & Relação entre secretário(a) escolar e ATB(s) & Observável \\
\hline & Relação entre a equipe de direçãoe as famílias dos alunos & Observável \\
\hline
\end{tabular}




\begin{tabular}{lll}
\hline Conceitos & \multicolumn{1}{c}{ Conceitos secundários } & Classificação \\
\hline & Elaborar relatórios e ofícios & Observável \\
\cline { 2 - 3 } & Contratar funcionários & Observável \\
\cline { 2 - 3 } & Condução escolar & Observável \\
\cline { 2 - 3 } & Evasão e abandono discente & Observável \\
\cline { 2 - 3 } & Desempenho discente & Observável \\
\cline { 2 - 3 } & Planejamento & Observável \\
\hline \multirow{5}{*}{$\begin{array}{c}\text { Atividades da } \\
\text { função }\end{array}$} & Entrada e saída discente & Observável \\
\cline { 2 - 3 } & Atender aos pedidos & Observável \\
\cline { 2 - 3 } & Assistir às aulas & Observável \\
\cline { 2 - 3 } & Relatório e mapa d enotas & Observável \\
\cline { 2 - 3 } & Planejamento escolar & Observável \\
\cline { 2 - 3 } & Desempenho discente & Observável \\
\cline { 2 - 3 } & Atender os pais & Observável \\
\cline { 2 - 3 } & Eventos na escola & Observável \\
\cline { 2 - 3 } & Dar aulas & Observável \\
\cline { 2 - 3 } & Acompanhar reuniões/conversas entre docentes e superviror & Observável \\
\cline { 2 - 3 } & Passeios pedagógicos & Observável \\
\cline { 2 - 3 } & &
\end{tabular}




\section{Anexo 6: Características das escolas}

Tabela: Distribuição das escolas segundo a sede

\begin{tabular}{c|c|c|c|c}
\hline \multirow{2}{*}{$\begin{array}{c}\text { Localização das escolas segundo } \\
\text { sede }\end{array}$} & \multicolumn{2}{|c|}{$\begin{array}{c}\text { Escolas Estaduais de } \\
\text { MG }\end{array}$} & \multicolumn{2}{c}{$\begin{array}{c}\text { Escolas com questionários } \\
\text { respondidos }\end{array}$} \\
\cline { 2 - 5 } & $\mathbf{N}$ & $\mathbf{N}$ & $\mathbf{N}$ & \% \\
\hline Zona Rural & 318 & 9,2 & 36 & 6,1 \\
\hline Zona Urbana Sede Distrito & 583 & 16,9 & 94 & 16,0 \\
\hline Zona Urbana Sede Município & 2543 & 73,8 & 456 & 77,8 \\
\hline Total & 3444 & 100,0 & 586 & 100,0 \\
\hline
\end{tabular}

Fonte: Elaboração própria a partir dos dados do Censo Escolar 2016

Tabela: Porte do município em que está localizada a escola

\begin{tabular}{l|l|l|l|l}
\hline \multirow{2}{*}{ Porte do município } & \multicolumn{2}{l|}{ Escolas Estaduais de MG } & \multicolumn{2}{l}{$\begin{array}{l}\text { Escolas com } \\
\text { respondidos }\end{array}$} \\
\cline { 2 - 5 } & $\mathbf{N}$ & questionários \\
\hline Pequeno porte & 1994 & 57,9 & $\mathbf{N}$ & $\%$ \\
\hline Médio porte & 1086 & 31,5 & 230 & 39,2 \\
\hline Grande porte & 364 & 10,6 & 244 & 41,6 \\
\hline Total & 3444 & 100,0 & 112 & 19,1 \\
\hline
\end{tabular}

Fonte: Elaboração própria a partir dos dados do Censo Escolar 2016

Tabela: Estatística descritiva de matrícula, segundo quantidade de turnos que a escola oferece

\begin{tabular}{|c|c|c|c|c|c|c|c|c|c|c|}
\hline \multirow[b]{2}{*}{\begin{tabular}{l}
\multicolumn{2}{l}{ Quantida } \\
de de \\
turnos \\
que as \\
escolas \\
oferecem \\
\end{tabular}} & \multicolumn{5}{|c|}{ Escolas Estaduais de MG } & \multicolumn{5}{|c|}{ Escolas com questionários respondidos } \\
\hline & $\begin{array}{l}\mathbf{N} \\
\text { Escola } \\
\text { S }\end{array}$ & $\begin{array}{l}\text { Média } \\
\text { de } \\
\text { Matrícu } \\
\text { las p/ } \\
\text { escola }\end{array}$ & DP & $\begin{array}{l}\text { Mi } \\
\mathbf{n}\end{array}$ & Max & $\begin{array}{l}\mathbf{N} \\
\text { Escolas }\end{array}$ & $\begin{array}{l}\text { Média } \\
\text { de } \\
\text { Matrícul } \\
\text { as p/ } \\
\text { escola }\end{array}$ & DP & $\begin{array}{l}\text { Mi } \\
\mathbf{n}\end{array}$ & Max \\
\hline Um & 80 & 137,74 & 83,92 & 9 & 377 & 13 & 229,08 & 86,84 & 67 & 677 \\
\hline Dois & 1677 & 456,65 & $\begin{array}{l}283,0 \\
2 \\
\end{array}$ & 14 & 2728 & 277 & 499,94 & 283,09 & 49 & 2164 \\
\hline Três & 1687 & 826,39 & $\begin{array}{l}427,3 \\
5\end{array}$ & 45 & 4191 & 296 & 891,84 & 448,19 & 113 & 2780 \\
\hline Total & 3444 & & & & & 586 & & & & \\
\hline
\end{tabular}

Fonte: Elaboração própria a partir dos dados do Censo Escolar 2016

Tabela: Quantidade de turnos oferecidos

\begin{tabular}{l|l|l|l|l|l}
\hline $\begin{array}{l}\text { Escolas Estaduais de } \\
\text { MG }\end{array}$ & \multicolumn{3}{c}{$\begin{array}{l}\text { Escolas com } \\
\text { respondidos }\end{array}$} & \multicolumn{2}{c}{ questionários } \\
\hline Turnos & $\mathrm{N}$ & $\%$ & Turnos & $\mathrm{N}$ & $\%$ \\
\hline 1 turno & 122 & 3,5 & 1 turno & 17 & 2,9 \\
\hline 2 turnos & 1644 & 47,7 & 2 turnos & 273 & 46,6 \\
\hline 3 turnos & 1678 & 48,7 & 3 turnos & 296 & 50,5 \\
\hline Total & 3444 & 100 & Total & 586 & 100,0 \\
\hline
\end{tabular}

Fonte: Elaboração própria a partir dos dados do Censo Escolar 2016

Tabela: Participação na Prova Brasil $-5^{\circ}$ ano

\begin{tabular}{|c|c|c|c|c|}
\hline \multirow{2}{*}{$\begin{array}{l}\text { Indicador se a escola } \\
\text { participou da Prova } \text { Brasil } \\
-5^{\circ} \text { ano* }\end{array}$} & \multicolumn{2}{|c|}{ Escolas Estaduais de MG } & \multicolumn{2}{|c|}{$\begin{array}{l}\text { Escolas com questionários } \\
\text { respondidos }\end{array}$} \\
\hline & $\mathrm{N}$ & $\%$ & $\mathrm{~N}$ & $\%$ \\
\hline Não & 569 & 29,0 & 63 & 19,4 \\
\hline Sim & 1396 & 71,0 & 261 & 80,6 \\
\hline Total & 1965 & 100,0 & 324 & 100,0 \\
\hline
\end{tabular}

*Foram consideradas apenas as escolas que oferecem o primeiro segmento do Ensino Fundamental

Fonte: Elaboração própria a partir dos dados da Prova Brasil de 2015 
Tabela: Participação na Prova Brasil - $9^{\circ}$ ano

\begin{tabular}{l|l|l|l|l}
\hline \multirow{2}{*}{$\begin{array}{l}\text { Indicador se a escola } \\
\text { participou da Prova Brasil }-\end{array}$} & $\begin{array}{l}\text { Escolas } \\
\text { MG }\end{array}$ & \multicolumn{2}{l|}{ Estaduais de } & $\begin{array}{l}\text { Escolas com questionários } \\
\text { respondidos }\end{array}$ \\
\cline { 2 - 5 } $\mathbf{9}^{\mathbf{0}}$ ano* & $\mathrm{N}$ & $\%$ & $\mathrm{~N}$ & $\%$ \\
\hline Não & 333 & 11,9 & 38 & 8,4 \\
\hline Sim & 2467 & 88,1 & 416 & 91,6 \\
\hline Total & 2800 & 100,0 & 454 & 100,0 \\
\hline
\end{tabular}

*Foram consideradas apenas as escolas que oferecem o segundo segmento do Ensino Fundamental

Fonte: Elaboração própria a partir dos dados da Prova Brasil de 2015

Tabela: Proficiência em Matemática no $5^{\circ}$ ano do Ensino Fundamental

\begin{tabular}{l|l|l}
\hline $\begin{array}{l}\text { Proficiência em Matemática - } \\
\mathbf{5}^{\mathbf{0}} \text { ano }\end{array}$ & Escolas Estaduais de MG & $\begin{array}{l}\text { Escolas com questionários } \\
\text { respondidos }\end{array}$ \\
\hline Média & 227,38 & 228,35 \\
\hline Desvio Padrão & 20,24 & 20,25 \\
\hline Valor mínimo & 173,58 & 185,37 \\
\hline Valor máximo & 289,70 & 284,89 \\
\hline & $\begin{array}{l}\text { Respostas Válidas = 1396 } \\
\text { Missing = 569 }\end{array}$ & $\begin{array}{l}\text { Respostas Válidas }=261 \\
\text { Missing = 63 }\end{array}$ \\
\hline
\end{tabular}

Fonte: Elaboração própria a partir dos dados da Prova Brasil de 2015

Tabela: Proficiência em Matemática no $9^{\circ}$ ano do Ensino Fundamental

\begin{tabular}{l|l|l}
\hline $\begin{array}{l}\text { Proficiência em Matemática - } \\
\mathbf{9}^{\mathbf{0}} \text { ano }\end{array}$ & Escolas Estaduais de MG & $\begin{array}{l}\text { Escolas com questionários } \\
\text { respondidos }\end{array}$ \\
\hline Média & 256,13 & 254,43 \\
\hline Desvio Padrão & 17,52 & 16,00 \\
\hline Valor mínimo & 200,60 & 220,41 \\
\hline Valor máximo & 336,22 & 304,36 \\
\hline & $\begin{array}{l}\text { Respostas Válidas = 2467 } \\
\text { Missing = 333 }\end{array}$ & $\begin{array}{l}\text { Respostas Válidas = 416 } \\
\text { Missing = 38 }\end{array}$ \\
\hline
\end{tabular}

Fonte: Elaboração própria a partir dos dados da Prova Brasil de 2015

Tabela: Percentual de pais do $5^{\circ}$ ano cujo nível de formação é ensino médio ou superior

\begin{tabular}{l|l|l}
\hline $\mathbf{5}^{\mathbf{o}}$ ano & Escolas Estaduais de MG & $\begin{array}{l}\text { Escolas com questionários } \\
\text { respondidos }\end{array}$ \\
\hline Média & 0,527 & 0,545 \\
\hline Desvio Padrão & 0,187 & 0,195 \\
\hline Valor mínimo & 0,000 & 0,080 \\
\hline Valor máximo & 0,980 & 0,980 \\
\hline & $\begin{array}{l}\text { Respostas Válidas = 1392 } \\
\text { Missing = 573 }\end{array}$ & $\begin{array}{l}\text { Respostas Válidas = 260 } \\
\text { Missing = 64 }\end{array}$ \\
\hline
\end{tabular}

Fonte: Elaboração própria a partir dos dados dos dados da Prova Brasil de 2015

Tabela: Percentual de pais do $9^{\circ}$ ano cujo nível de formação é ensino médio ou superior

\begin{tabular}{l|l|l}
\hline $\mathbf{9}^{\mathbf{0}}$ ano & Escolas Estaduais de MG & $\begin{array}{l}\text { Escolas com questionários } \\
\text { respondidos }\end{array}$ \\
\hline Média & 0,437 & 0,460 \\
\hline Desvio Padrão & 0,186 & 0,178 \\
\hline Valor mínimo & 0,000 & 0,000 \\
\hline Valor máximo & 1,000 & 0,930 \\
\hline & $\begin{array}{l}\text { Respostas Válidas }=2451 \\
\text { Missing = 349 }\end{array}$ & $\begin{array}{l}\text { Respostas Válidas }=413 \\
\text { Missing }=41\end{array}$
\end{tabular}

Fonte: Elaboração própria a partir dos dados da Prova Brasil de 2015

Tabela: Acesso ao cargo de diretor 


\begin{tabular}{lllll}
\hline Acesso ao cargo de diretor & \multicolumn{2}{l}{ Escolas Estaduais de MG } & $\begin{array}{l}\text { Escolas com } \\
\text { respondidos }\end{array}$ & questionários \\
& $\mathrm{N}$ & $\%$ & $\mathrm{~N}$ & $\%$ \\
\hline Concurso público apenas & 22 & 0,8 & 4 & 0,8 \\
Eleição apenas & 465 & 16,6 & 90 & 18,4 \\
Indicação apenas & 396 & 14,2 & 71 & 14,5 \\
Processo seletivo apenas & 15 & 0,5 & 4 & 0,8 \\
Processo seletivo e eleição & 1476 & 52,8 & 245 & 50,2 \\
Processo seletivo e indicação & 335 & 12,0 & 59 & 12,1 \\
Outra forma & 88 & 3,1 & 15 & 3,1 \\
Total & 2797 & 100,0 & 488 & 100,0 \\
Missing & $423^{*}$ & & $50^{*}$ & \\
\hline
\end{tabular}

* Como 224 escolas estaduais de Minas Gerais oferecem apenas o Ensino Médio, não teriam como responder essa questão que foi extraída da Prova Brasil, de maneira que o universo de escolas que poderia responder tal pergunta é 3220. Ou seja, as escolas que possuíam apenas o Ensino Médio foram desconsideradas.

**Como 48 escolas com questionários respondidos oferecem apenas o Ensino Médio, não teriam como responder essa questão que foi extraída da Prova Brasil, de maneira que o universo de escolas que poderia responder tal pergunta é 538. Ou seja, as escolas que possuíam apenas o Ensino Médio foram desconsideradas.

Tabela: Distribuição das escolas por SRE

\begin{tabular}{l|l|l|l|l}
\hline \multirow{2}{*}{ Polo Regional } & \multicolumn{2}{l|}{ Escolas Estaduais de MG } & \multicolumn{2}{l}{$\begin{array}{l}\text { Escolas com questionários } \\
\text { respondidos }\end{array}$} \\
\cline { 2 - 5 } & $\mathrm{N}$ & $\%$ & $\mathrm{~N}$ & $\%$ \\
\hline Polo Regional Centro & 836 & 24,3 & 222 & 37,9 \\
\hline Polo Regional Sul & 420 & 12,2 & 82 & 14,0 \\
\hline Polo Regional Mata & 421 & 12,2 & 86 & 14,7 \\
\hline Polo Regional Triângulo & 405 & 11,8 & 60 & 10,2 \\
\hline Polo Regional Norte & 568 & 16,5 & 45 & 7,7 \\
\hline Polo Regional Vale do Aço & 794 & 23,1 & 91 & 15,5 \\
\hline Total & 3444 & 100,0 & 586 & 100,0 \\
\hline
\end{tabular}

Fonte: Elaboração própria a partir dos microdados do Censo Escolar 2016 e dos questionários respondidos 


\section{Anexo 7: Características dos sujeitos}

Tabela: Qual o seu cargo?

\begin{tabular}{l|l|l}
\hline Cargo & N & $\%$ \\
\hline Secretário(a) & 402 & 68,6 \\
\hline ATB & 184 & 31,4 \\
\hline Total & 586 & 100,0 \\
\hline Casos
\end{tabular}

Casos válidos: 586 (100\%). Missing: 0 (0\%)

Tabela: Qual o seu cargo?

\begin{tabular}{l|l|l}
\hline Qual o seu cargo? & $\mathrm{N}$ & $\%$ \\
\hline Diretor(a) & 547 & 93,3 \\
\hline Vice-diretor(a) & 39 & 6,7 \\
\hline Total & 586 & 100,0 \\
\hline
\end{tabular}

Casos válidos: $586(100 \%)$. Missing: 0 (0\%)

Tabela: Qual o seu sexo?

\begin{tabular}{l|l|l}
\hline Sexo & $\mathrm{N}$ & $\%$ \\
\hline Feminino & 514 & 87,7 \\
\hline Masculino & 72 & 12,3 \\
\hline Total & 586 & 100,0 \\
\hline Casos valics: $586(100 \%)$. Missing: &
\end{tabular}

Casos válidos: 586 (100\%). Missing: 0 (0\%)

Tabela: Qual o seu sexo? (diretor)

\begin{tabular}{l|l|l}
\hline Sexo & $\mathrm{N}$ & $\%$ \\
\hline Feminino & 411 & 72,1 \\
\hline Masculino & 159 & 27,9 \\
\hline Total & 799 & 100,0
\end{tabular}

Casos válidos: 570 (97,3\%). Missing: 16 (2,7\%)

Tabela: Como você se considera?

\begin{tabular}{l|l|l}
\hline Cor & N & $\%$ \\
\hline Branco(a) & 239 & 40,8 \\
\hline Pardo(a) & 289 & 49,3 \\
\hline Preto(a) & 45 & 7,7 \\
\hline Amarelo(a) & 3 &, 5 \\
\hline Indígena & 2 &, 3 \\
\hline Não quero me declarar & 7 & 1,2 \\
\hline Não sei & 1 &, 2 \\
\hline Total & 586 & 100,0 \\
\hline
\end{tabular}

Casos válidos: 586 (100\%). Missing: 0 (0\%)

Tabela: Como você se considera? (diretor)

\begin{tabular}{l|l|l}
\hline Cor & N & $\%$ \\
\hline Branco(a) & 288 & 50,5 \\
\hline Pardo(a) & 234 & 41,1 \\
\hline Preto(a) & 37 & 6,5 \\
\hline Amarelo(a) & 7 & 1,2 \\
\hline Indígena & 1 & 0,2 \\
\hline Não quero me declarar & 3 & 0,5 \\
\hline Não sei & 570 & 50,5 \\
\hline Total & 288 & 100,0 \\
\hline
\end{tabular}

Casos válidos: 570 (97,3\%). Missing: $16(2,7 \%)$

Tabela: Tempo de trabalho

\begin{tabular}{l|l|l|l}
\hline Estatísticas descritivas & $\begin{array}{l}\text { Tempo de trabalho } \\
\text { como docente }\end{array}$ & $\begin{array}{l}\text { Tempo de trabalho em } \\
\text { secretaria de escola }\end{array}$ & $\begin{array}{l}\text { Tempo de trabalho na } \\
\text { secretaria desta escola }\end{array}$ \\
\hline
\end{tabular}




\begin{tabular}{l|l|l|l}
\hline Média & 8,7342 & 13,1768 & 9,0506 \\
\hline Mediana & 5,0000 & 14,0000 & 6,0000 \\
\hline Desvio Padrão & 8,22491 & 8,62306 & 7,50534 \\
\hline Valor mínimo & 0,00 & 0,00 & 0,00 \\
\hline Valor máximo & 33,00 & 35,00 & 26,00 \\
\hline & $\mathrm{N}=301$ & $\mathrm{~N}=586$ & $\mathrm{~N}=585$ \\
& Missing $=285$ & Missing $=0$ & Missing $=1$ \\
\hline
\end{tabular}

Tabela: Tempo de trabalho (diretor)

\begin{tabular}{l|l|l|l}
\hline Estatísticas descritivas & $\begin{array}{l}\text { Tempo de trabalho como } \\
\text { docente }\end{array}$ & $\begin{array}{l}\text { Tempo de trabalho } \\
\text { como diretor ou vice- } \\
\text { diretor de escola }\end{array}$ & $\begin{array}{l}\text { Tempo de trabalho } \\
\text { como diretor ou vice- } \\
\text { diretor desta escola }\end{array}$ \\
\hline Média & 15,271 & 1,6714 & 1,7627 \\
\hline Mediana & 15,000 & 2,0000 & 2,0000 \\
\hline Desvio Padrão & 6,9173 & 0,69902 & 0,73992 \\
\hline Valor mínimo & 0,5 & 1,00 & 1,00 \\
\hline Valor máximo & 34,0 & 4,00 & 4,00 \\
\hline & $\begin{array}{l}\mathrm{N}=544 \\
\text { Faltante }=22\end{array}$ & $\begin{array}{l}\mathrm{N}=569 \\
\text { Faltante }=17\end{array}$ & $\begin{array}{l}\mathrm{N}=569 \\
\text { Faltante }=17\end{array}$ \\
\hline
\end{tabular}

Fonte: Questionários do diretor e secretário escolar

Tabela: Provimento do Cargo

\begin{tabular}{lllll}
\hline Formas de Provimento do cargo & $\begin{array}{l}\text { Diretores } \\
\text { diretores }\end{array}$ & $\mathrm{e}$ & vice- & $\begin{array}{l}\text { Secretários } \\
\text { e ATBs }\end{array}$ \\
\hline Indicação & $\mathrm{N}$ & $\%$ & $\mathrm{~N}$ & $\%$ \\
Eleição & 30 & 5,3 & 189 & 32,3 \\
Processo seletivo e eleição & 259 & 45,4 & - & - \\
Concurso público & 280 & 49,1 & - & - \\
Contrato & 1 & 0,2 & 306 & 52,2 \\
Total & - & - & 91 & 15,5 \\
Q & 570 & 100,0 & 586 & 100,0 \\
\hline
\end{tabular}

Fonte: Questionários de diretor e secretário

Questionário do Diretor (provimento do Cargo): Casos válidos: 570 (97,3\%). Missing: 16 (2,7\%)

Tabela: Indique com que frequência você realiza as seguintes atividades no seu trabalho na secretaria da escola:

\begin{tabular}{|c|c|c|c|c|c|}
\hline $\begin{array}{l}\text { Frequência com que realiza as } \\
\text { atividades no trabalho na secretaria da } \\
\text { escola: }\end{array}$ & Nunca & Raramente & $\begin{array}{l}\text { Algumas } \\
\text { vezes }\end{array}$ & Frequentemente & Total \\
\hline $\begin{array}{l}\text { Ler as legislações e orientações } \\
\text { educacionais da SEE/MG }\end{array}$ & $1(0,2 \%)$ & $12(2,2 \%)$ & $131(24,2 \%)$ & $398(73,4 \%)$ & $542(100,0 \%)$ \\
\hline Ler os emails da escola & $1(0,2 \%)$ & $7(1,3 \%)$ & $23(4,2 \%)$ & $511(94,3 \%)$ & $542(100,0 \%)$ \\
\hline $\begin{array}{l}\text { Organizar a documentação dos alunos } \\
\text { em armários, gavetas, etc. }\end{array}$ & $8(1,5 \%)$ & $32(5,9 \%)$ & $139(25,6 \%)$ & $363(67,0 \%)$ & $542(100,0 \%)$ \\
\hline Atender pais & $5(0,9 \%)$ & $53(9,8 \%)$ & $143(26,4 \%)$ & $341(62,9 \%)$ & $542(100,0 \%)$ \\
\hline Atender o supervisor escolar & $0(0,0 \%)$ & $10(1,8 \%)$ & $99(18,3 \%)$ & $433(79,9 \%)$ & $542(100,0 \%)$ \\
\hline $\begin{array}{l}\text { Assegurar que os dados dos alunos } \\
\text { estejam corretos para a migração para } \\
\text { o Censo Escolar (Educacenso) }\end{array}$ & $4(0,7 \%)$ & $2(0,4 \%)$ & $41(7,6 \%)$ & $495(91,3 \%)$ & $542(100,0 \%)$ \\
\hline $\begin{array}{l}\text { Distribuir o serviço da secretaria entre } \\
\text { a equipe de Assistentes Técnicos da } \\
\text { Educação Básica (ATBs) }\end{array}$ & $26(4,8 \%)$ & $29(5,4 \%)$ & $95(17,5 \%)$ & $392(72,3 \%)$ & $542(100,0 \%)$ \\
\hline $\begin{array}{l}\text { Tirar dúvidas e resolver pendências } \\
\text { com a equipe do SEDINE }\end{array}$ & $5(0,9 \%)$ & $35(6,5 \%)$ & $195(36,0 \%)$ & $307(56,6 \%)$ & $542(100,0 \%)$ \\
\hline $\begin{array}{l}\text { Tomar decisões em relação a } \\
\text { secretaria junto com o diretor(a) }\end{array}$ & $7(1,3 \%)$ & $21(3,9 \%)$ & $96(17,7 \%)$ & $418(77,1 \%)$ & $542(100,0 \%)$ \\
\hline
\end{tabular}

Casos válidos: 542 (92,5\%). Missing: 44 (7,5\%) 
Tabela: clima escolar

\begin{tabular}{|c|c|c|c|c|c|c|}
\hline $\begin{array}{l}\text { Avaliação dos aspectos da } \\
\text { escola }\end{array}$ & Muito ruim & Ruim & Regular & Boa & Muito boa & Total \\
\hline $\begin{array}{l}\text { Relação entre funcionários } \\
\text { da secretaria da escola e } \\
\text { direção escolar }\end{array}$ & $0(0,0 \%)$ & $0(0,0 \%)$ & $18(3,2 \%)$ & $186(33,5 \%)$ & $352(63,3 \%)$ & $556(100,0 \%)$ \\
\hline $\begin{array}{l}\text { Relação entre professores e } \\
\text { supervisão escolar }\end{array}$ & $1(0,2 \%)$ & $6(1,1 \%)$ & $55(9,9 \%)$ & $297(53,4 \%)$ & $197(35,4 \%)$ & $556(100,0 \%)$ \\
\hline $\begin{array}{l}\text { Relação dos professores com } \\
\text { os alunos }\end{array}$ & $1(0,2 \%)$ & $2(0,4 \%)$ & $51(9,2 \%)$ & $343(61,7 \%)$ & $159(28,6 \%)$ & $556(100,0 \%)$ \\
\hline $\begin{array}{l}\text { Relação entre professores e } \\
\text { direção escolar }\end{array}$ & $0(0,0 \%)$ & $1(0,2 \%)$ & $45(8,1 \%)$ & $298(53,6 \%)$ & $212(38,1 \%)$ & $556(100,0 \%)$ \\
\hline $\begin{array}{l}\text { Relação entre supervisão e } \\
\text { direção escolar }\end{array}$ & $0(0,0 \%)$ & $0(0,0 \%)$ & $34(6,1 \%)$ & $264(47,5 \%)$ & $258(46,4 \%)$ & $556(100,0 \%)$ \\
\hline $\begin{array}{l}\text { Relação entre Secretário(a) } \\
\text { escolar e ATB(s) }\end{array}$ & $1(0,2 \%)$ & $1(0,2 \%)$ & $14(2,5 \%)$ & $158(28,4 \%)$ & $382(68,7 \%)$ & $556(100,0 \%)$ \\
\hline $\begin{array}{l}\text { Relação entre a direção } \\
\text { escolar e as famílias dos } \\
\text { alunos }\end{array}$ & $0(0,0 \%)$ & $0(0,0 \%)$ & $24(4,3 \%)$ & $266(47,8 \%)$ & $266(47,8 \%)$ & $556(100,0 \%)$ \\
\hline
\end{tabular}

Casos válidos: 556 (94,9\%). Missing: 30 (5,1\%)

Tabela: Clima escolar (diretor)

\begin{tabular}{|c|c|c|c|c|c|}
\hline $\begin{array}{l}\text { Sobre o seu trabalho na } \\
\text { direção desta escola, } \\
\text { marque qual é o seu nível } \\
\text { de concordância com } \\
\text { cada uma das afirmativas } \\
\text { abaixo: }\end{array}$ & $\begin{array}{l}\text { Discordo } \\
\text { totalmente }\end{array}$ & $\begin{array}{l}\text { Discordo em } \\
\text { parte }\end{array}$ & $\begin{array}{l}\text { Concordo em } \\
\text { parte }\end{array}$ & $\begin{array}{l}\text { Concordo } \\
\text { totalmente }\end{array}$ & Total \\
\hline $\begin{array}{l}\text { Sinto-me satisfeito com } \\
\text { as relações estabelecidas } \\
\text { no meu local de trabalho }\end{array}$ & $2(0,4 \%)$ & $14(2,5 \%)$ & $265(46,7 \%)$ & $286(50,4 \%)$ & $\begin{array}{l}567 \\
(100 \%)\end{array}$ \\
\hline $\begin{array}{l}\text { Sinto-me estressado (a) } \\
\text { com o volume de } \\
\text { demandas que o trabalho } \\
\text { da direção escolar me } \\
\text { exige }\end{array}$ & $42(7,4 \%)$ & $108(19 \%)$ & $303(53,4 \%)$ & $114(20,1 \%)$ & $\begin{array}{l}567 \\
(100 \%)\end{array}$ \\
\hline $\begin{array}{l}\text { Sinto-me pouco } \\
\text { apoiado(a) em relação aos } \\
\text { recursos financeiros e } \\
\text { pessoais necessários para } \\
\text { manter o pleno } \\
\text { funcionamento da escola }\end{array}$ & $32(5,6 \%)$ & $89(15,7 \%)$ & $275(48,5 \%)$ & $171(30,2 \%)$ & $\begin{array}{l}567 \\
(100 \%)\end{array}$ \\
\hline $\begin{array}{l}\text { Sinto-me frustrado(a) } \\
\text { pelo pouco controle e } \\
\text { baixa interferência que } \\
\text { tenho sobre os projetos } \\
\text { encaminhados pela SRE e } \\
\text { pela SEE para a escola }\end{array}$ & $122(21,5 \%)$ & $160(28,2 \%)$ & $231(40,7 \%)$ & $54(9,5 \%)$ & $\begin{array}{l}567 \\
(100 \%)\end{array}$ \\
\hline $\begin{array}{l}\text { Divido responsabilidades } \\
\text { do SIMADE com a } \\
\text { equipe da secretaria da } \\
\text { escola }\end{array}$ & $8(1,4 \%)$ & $14(2,5 \%)$ & $66(11,6 \%)$ & $479(84,5 \%)$ & $\begin{array}{l}567 \\
(100 \%)\end{array}$ \\
\hline $\begin{array}{l}\text { O planejamento anual das } \\
\text { atividades é elaborado } \\
\text { com a participação dos } \\
\text { professores e demais } \\
\text { profissionais da escola }\end{array}$ & $2(0,4 \%)$ & $7(1,2 \%)$ & $100(17,6 \%)$ & $458(80,8 \%)$ & $\begin{array}{l}567 \\
(100 \%)\end{array}$ \\
\hline $\begin{array}{l}\text { Para tomar decisões, ouço } \\
\text { os profissionais da escola }\end{array}$ & $5(0,9 \%)$ & $6(1,1 \%)$ & $107(18,9 \%)$ & $449(79,2 \%)$ & $\begin{array}{l}567 \\
(100 \%)\end{array}$ \\
\hline
\end{tabular}

Casos válidos: 567 (96,8\%). Missing: 19 (3,2\%) 


\section{Anexo 8: Infraestrutura tecnológica}

Tabela: Condições de uso dos recursos

\begin{tabular}{|c|c|c|c|c|c|c|}
\hline \multicolumn{7}{|c|}{ Computadores para uso exclusivo } \\
\hline & $\begin{array}{l}\text { Da } \\
\text { equipe } \\
\text { de gestão }\end{array}$ & $\begin{array}{l}\text { Da equipe } \\
\text { da } \\
\text { secretaria }\end{array}$ & $\begin{array}{l}\text { Sala dos } \\
\text { professores }\end{array}$ & $\begin{array}{l}\text { Sala da } \\
\text { supervisão }\end{array}$ & $\begin{array}{l}\text { Computador } \\
\text { (notebook, } \\
\text { netbook, tablet) }\end{array}$ & $\begin{array}{l}\text { portátil } \\
\text { laptop, }\end{array}$ \\
\hline $\begin{array}{l}\text { Bom estado de } \\
\text { conservação }\end{array}$ & $81,6 \%$ & $80,5 \%$ & $54,5 \%$ & $64,3 \%$ & $54,8 \%$ & \\
\hline $\begin{array}{l}\text { Necessitam de } \\
\text { pequeno } \\
\text { reparo }\end{array}$ & $13,8 \%$ & $15,1 \%$ & $23,7 \%$ & $16,9 \%$ & $21,3 \%$ & \\
\hline $\begin{array}{l}\text { Necessitam de } \\
\text { grande reparo }\end{array}$ & $2,4 \%$ & $4,0 \%$ & $8,2 \%$ & $7,3 \%$ & $10,6 \%$ & \\
\hline $\begin{array}{l}\text { Não possui o } \\
\text { recurso }\end{array}$ & $2,2 \%$ & $0,4 \%$ & $13,7 \%$ & $11,5 \%$ & $13,3 \%$ & \\
\hline Total & $100 \%$ & $100 \%$ & $100 \%$ & $100 \%$ & $100 \%$ & \\
\hline
\end{tabular}

Fonte: Questionário do secretário

Casos válidos: 549 (93,7\%). Faltantes: 37 (6,3\%)

Tabela: Conteúdo do curso do SIMADE

\begin{tabular}{lllll}
\hline $\begin{array}{l}\text { Caso tenha participado de algum curso sobre } \\
\text { o SIMADE, quais foram os assuntos }\end{array}$ & $\begin{array}{l}\text { Diretor } \\
\text { Respostas }\end{array}$ & \multicolumn{3}{l}{$\begin{array}{l}\text { Secretário e ATB } \\
\text { Respostas }\end{array}$} \\
tratados? & $\mathrm{N}$ & $\%$ & & \\
\hline $\begin{array}{l}\text { Não participei de nenhum curso sobre o } \\
\text { SIMADE }\end{array}$ & 355 & $38,1 \%$ & 212 & $18,0 \%$ \\
$\begin{array}{l}\text { Cadastro, Matrícula, Enturmação, } \\
\text { Avaliação, Frequência e Histórico }\end{array}$ & 192 & $20,6 \%$ & 281 & $23,8 \%$ \\
$\begin{array}{l}\text { Dados de preenchimento obrigatório para } \\
\text { migração para o Censo Escolar }\end{array}$ & 132 & $14,2 \%$ & 239 & $20,3 \%$ \\
$\begin{array}{l}\text { Emissão de declarações, boletins, atas e } \\
\text { mapa de desempenho }\end{array}$ & 114 & $12,2 \%$ & 158 & $13,4 \%$ \\
$\begin{array}{l}\text { Criar Pacote, Programa Pedagógico, } \\
\text { Cadastro de Turma e Encerramento do }\end{array}$ & 122 & $13,1 \%$ & 238 & $20,2 \%$ \\
$\begin{array}{l}\text { Período Letivo } \\
\text { Outros assuntos }\end{array}$ & 16 & $1,7 \%$ & 52 & $4,4 \%$ \\
Total & 931 & $100,0 \%$ & 1180 & $100,0 \%$ \\
\hline
\end{tabular}

Questionário do Diretor - Casos válidos: 570 (97,3\%). Faltantes: 16 (2,7\%)

Questionário do Secretário - Casos válidos: 570 (97,3\%). Faltantes: 16 (2,7\%) 


\section{Anexo 9 - Autoeficácia do diretor}

KMO and Bartlett's Test

\begin{tabular}{|ll|l|}
\hline $\begin{array}{l}\text { Kaiser-Meyer-Olkin } \\
\text { Adequacy. }\end{array}$ & Measure of Sampling &, 674 \\
Bartlett's Test of Approx. Chi-Square & 424,300 \\
Sphericity & df & 3 \\
& Sig. &, 000 \\
\hline
\end{tabular}

Reliability Statistics

\begin{tabular}{|l|l|}
\hline $\begin{array}{l}\text { Cronbach's } \\
\text { Alpha }\end{array}$ & N of Items \\
\hline, 747 & 3 \\
\hline
\end{tabular}

Total Variance Explained

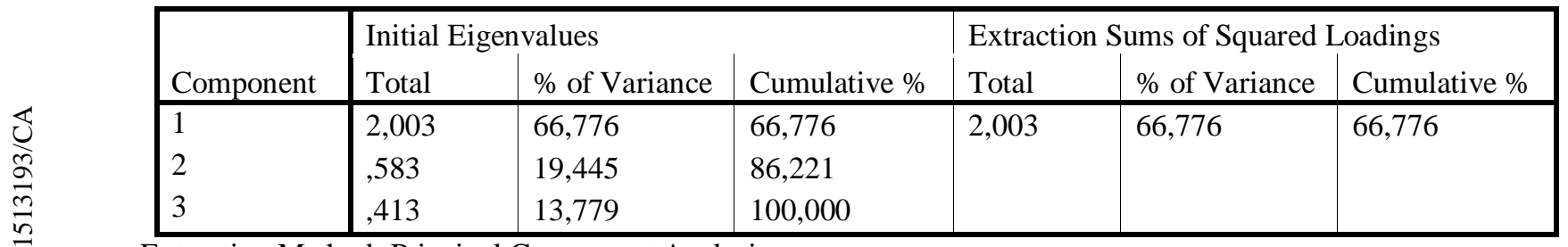

Extraction Method: Principal Component Analysis.

Component Matrix(a)

\begin{tabular}{|l|l|}
\hline & $\begin{array}{l}\text { Componen } \\
\mathrm{t}\end{array}$ \\
\hline $\begin{array}{l}\text { Em sua função de diretor } \\
\text { o quanto você consegue: }\end{array}$ & 1 \\
$\begin{array}{l}\text { Planejar e cumprir as } \\
\text { atividades de seu trabalho }\end{array}$ &, 852 \\
$\begin{array}{l}\text { Resolver os problemas } \\
\text { burocráticos inerentes à } \\
\text { função } \\
\text { Apoiar o trabalho } \\
\text { pedagógico dos } \\
\text { professores }\end{array}$ &, 771 \\
\hline
\end{tabular}

Extraction Method: Principal Component Analysis. 
Tabela: Estatísticas descritivas ANOVA - Autoeficácia do diretor x idade.

Descriptives

Indicador de autoeficácia do diretor com base nas variáveis 7 de 1 a 3

\begin{tabular}{|c|c|c|c|c|c|c|c|c|}
\hline & \multirow[b]{2}{*}{$\mathrm{N}$} & \multirow[b]{2}{*}{ Mean } & \multirow[b]{2}{*}{ Std. Deviation } & \multirow[b]{2}{*}{ Std. Error } & \multicolumn{2}{|c|}{$\begin{array}{l}95 \% \text { Confidence Interval for } \\
\text { Mean }\end{array}$} & \multirow[b]{2}{*}{ Minimum } & \multirow[b]{2}{*}{ Maximum } \\
\hline & & & & & Lower Bound & Upper Bound & & \\
\hline Até 40 anos & 103 &, 034 & 1,0996 & , 1083 &,- 181 & 248 & $-3,2$ & $\overline{1,9}$ \\
\hline De 41 a 55 anos & 368 &,- 015 &, 9505 &, 0495 &,- 112 &, 082 & $-3,1$ & 1,9 \\
\hline 56 anos ou mais & 96 &, 036 & 1,0886 & ,1111 &,- 185 &, 256 & $-3,8$ & 1,9 \\
\hline Total & 567 &, 002 & 1,0016 &, 0421 &,- 080 &, 085 & $-3,8$ & 1,9 \\
\hline
\end{tabular}

Fonte: Questionário do diretor.

$\mathrm{N}$ se refere ao número de diretores; Mean é a média de cada medida; Std. Deviation é o desvio padrão; Std. Error é o erro padrão, que corresponde à média dividida pela raiz quadrada de N; Lower Bound e Upper Bound correspondem, respectivamente ao limite inferior e superior de intervalos de 95\% de confiança para as médias de cada um dos três grupos de respondentes. Por fim, os valores mínimo (Minimum) e máximo (Maximum) de cada resposta.

Tabela: Estatísticas descritivas das distribuições dos resultados médios de Matemática das escolas da amostra, para o $5^{\circ}$ e $9^{\circ}$ anos do Ensino Fundamental, na Prova Brasil 2015 e SIMAVE 2016:

\begin{tabular}{llllll}
\hline & & 5EF_PB & 9EF_PB & 5EF_SIMAVE & 5EF_SIMAVE \\
& & 2015 & 2015 & 2016 & 2016 \\
\hline \multirow{2}{*}{ Casos } & Válidos & 265 & 417 & 322 & 451 \\
& Faltantes & 321 & 169 & 264 & 135 \\
\multirow{2}{*}{ Média } & 222,8 & 257,6 & 233,4 & 249,5 \\
\multicolumn{2}{l}{ Desvio-padrão } & 15,7 & 11,3 & 25,4 & 17,7 \\
\hline
\end{tabular}

Fonte: Survey GESQ_SIMADE_2018, Prova Brasil 2015 e SIMAVE 2016.

Tabela: Estatísticas descritivas do indicador geral de desempenho em matemática (média dos 4 escores padronizados desta disciplina):

\begin{tabular}{lll}
\hline Estatística & Casos & \\
\hline & Válidos & 578 \\
& Faltantes & 8 \\
Média & & 0,02 \\
DP & & 0,74 \\
Percentis & 25 & $-0,46$ \\
& 50 & 0,01 \\
& 75 & 0,46 \\
\hline
\end{tabular}

Fonte: Prova Brasil 2015 e SIMAVE 2016.

Tabela: Regressão linear dos resultados escolares.

\begin{tabular}{|l|l|l|ll|l|}
\hline Model & R & R Square & $\begin{array}{l}\text { Adjusted } \\
\text { Square }\end{array}$ & R & Std. Error of the Estimate \\
\hline 1 &, $027(a)$ &, 001 &,- 001 & 1,0029 \\
\hline
\end{tabular}

Fonte: Questionário do diretor.

a Predictors: (Constant), MAT_MED_GER

b Dependent Variable: Indicador de autoeficácia do diretor com base nas variáveis 7 de 1 a 3 
Tabela: ANOVA - Regressão linear dos resultados escolares:

\begin{tabular}{|l|l|l|l|l|l|}
\hline & Sum of Squares & df & Mean Square & F & Sig. \\
\hline Regression &, 423 & 1 &, 423 &, 420 &, $517(\mathrm{a})$ \\
Residual & 579,297 & 576 & 1,006 & & \\
Total & 579,720 & 577 & & & \\
\hline
\end{tabular}

Fonte: Questionário do diretor

a Predictors: (Constant), MAT_MED_GER

b Dependent Variable: Indicador de autoeficácia do diretor com base nas variáveis 7 de 1 a 3

Sum of squares é a soma dos quadrados; DF é o desvio padrão; Mean Square é a média dos quadrados; F e Sig é a significância.

Tabela: Anova do indicador de autoeficácia e atividades do diretor.

\begin{tabular}{|c|c|c|c|c|c|c|c|c|}
\hline \multicolumn{9}{|c|}{ Resultados da Anova } \\
\hline & & & & & & & \multicolumn{2}{|c|}{$\begin{array}{c}\text { Significativo no nível } \\
\text { de confiança de }\end{array}$} \\
\hline & & \multicolumn{2}{|c|}{ Sum of Sq df } & \multicolumn{2}{|l|}{ Mean Squ F } & Sig. & \multicolumn{2}{|l|}{$95 \%$} \\
\hline \multirow{3}{*}{ Acompanhar a entrada e saída dos alunos } & Between Groups & 4,614482 & 2 & 2,307241 & 9,541923 & 0,0000844835 & Sim & Sim \\
\hline & Within Groups & 132,023 & 546 & 0,2418 & & & & \\
\hline & Total & 136,6375 & 548 & & & & & \\
\hline \multirow{3}{*}{$\begin{array}{l}\text { Atender aos pedidos dos professores } \\
\text { (equipamentos, materiais) }\end{array}$} & Between Groups & 1,987893 & 2 & 0,993946 & 3,891547 & 0,0209823957 & $\operatorname{Sim}$ & Não \\
\hline & Within Groups & 139,4547 & 546 & 0,255412 & & & & \\
\hline & Total & 141,4426 & 548 & & & & & \\
\hline \multirow{3}{*}{ Assistir às aulas (ou parte delas) } & Between Groups & 10,24593 & 2 & 5,122967 & 10,01448 & 0,0000535354 & Sim & Sim \\
\hline & Within Groups & 279,3096 & 546 & 0,511556 & & & & \\
\hline & Total & 289,5556 & 548 & & & & & \\
\hline \multirow{3}{*}{ Elaborar relatórios e mapas de notas } & Between Groups & 17,2725 & 2 & 8,63625 & 13,5692 & 0,0000017732 & Sim & Sim \\
\hline & Within Groups & 347,5071 & 546 & 0,63646 & & & & \\
\hline & Total & 364,7796 & 548 & & & & & \\
\hline \multirow{3}{*}{$\begin{array}{l}\text { Orientar o planejamento escolar } \\
\text { (conteúdos a priorizar, estratégias de } \\
\text { ensino e formas de avaliação) }\end{array}$} & Between Groups & 14,9856 & 2 & 7,492801 & 20,08962 & 0,0000000038 & Sim & Sim \\
\hline & Within Groups & 203,641 & 546 & 0,372969 & & & & \\
\hline & Total & 218,6266 & 548 & & & & & \\
\hline \multirow{3}{*}{$\begin{array}{c}\text { Conversar com os professores sobre o } \\
\text { desempenho de seus alunos nas } \\
\text { avaliações }\end{array}$} & Between Groups & 3,440965 & 2 & 1,720483 & 9,132841 & 0,0001254754 & $\operatorname{Sim}$ & Sim \\
\hline & Within Groups & 102,8578 & 546 & 0,188384 & & & & \\
\hline & Total & 106,2987 & 548 & & & & & \\
\hline \multirow{3}{*}{ Atender os pais } & Between Groups & 2,120497 & 2 & 1,060249 & 8,394481 & 0,0002565964 & $\operatorname{Sim}$ & Sim \\
\hline & Within Groups & 68,96147 & 546 & 0,126303 & & & & \\
\hline & Total & 71,08197 & 548 & & & & & \\
\hline \multirow{3}{*}{ Organizar festas e eventos da escola } & Between Groups & 1,903945 & 2 & 0,951973 & 1,834027 & 0,1607517836 & Não & Não \\
\hline & Within Groups & 283,4075 & 546 & 0,519061 & & & & \\
\hline & Total & 285,3115 & 548 & & & & & \\
\hline \multirow{3}{*}{ Dar aulas quando algum professor falta } & Between Groups & 4,644122 & 2 & 2,322061 & 3,165687 & 0,0429605611 & Sim & Não \\
\hline & Within Groups & 400,4961 & 546 & 0,733509 & & & & \\
\hline & Total & 405,1403 & 548 & & & & & \\
\hline \multirow{3}{*}{$\begin{array}{l}\text { Acompanhar reuniões e/ou conversas } \\
\text { entre o supervisor e o professor sobre } \\
\text { alunos }\end{array}$} & Between Groups & 1,963127 & 2 & 0,981564 & 3,476953 & 0,0315873637 & Sim & Não \\
\hline & Within Groups & 154,1389 & 546 & 0,282306 & & & & \\
\hline & Total & 156,102 & 548 & & & & & \\
\hline \multirow{3}{*}{ Acompanhar os passeios pedagógicos } & Between Groups & 1,071706 & 2 & 0,535853 & 0,848562 & 0,4285935411 & Não & Não \\
\hline & Within Groups & 344,7899 & 546 & 0,631483 & & & & \\
\hline & Total & 345,8616 & 548 & & & & & \\
\hline
\end{tabular}

Fonte: Questionário do diretor 
Gráfico: Acompanhar a entrada e saída dos alunos:

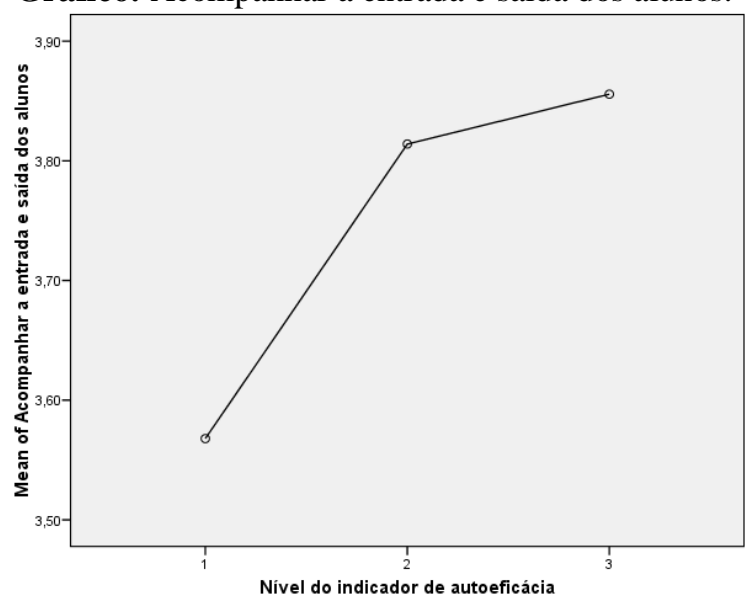

Fonte: Questionário do diretor.

Gráfico: Atender aos pais.

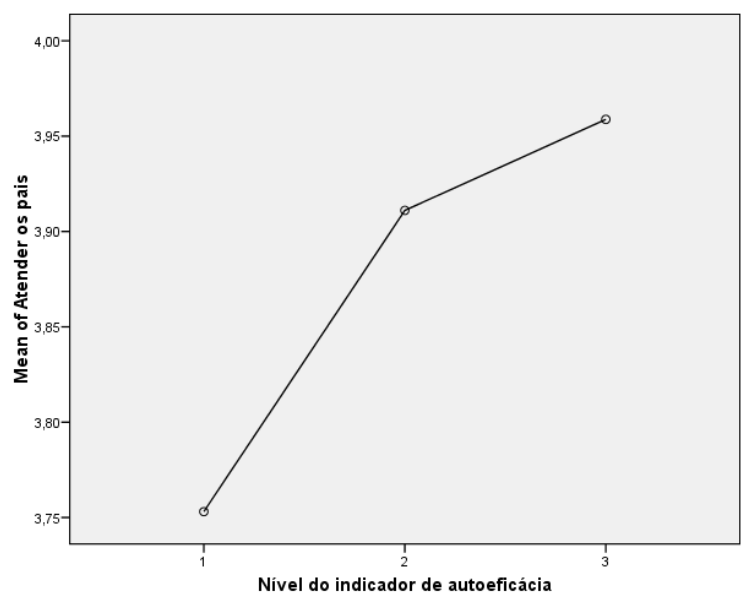

Fonte: Questionário do diretor

Gráfico: Assistir às aulas (ou parte delas):

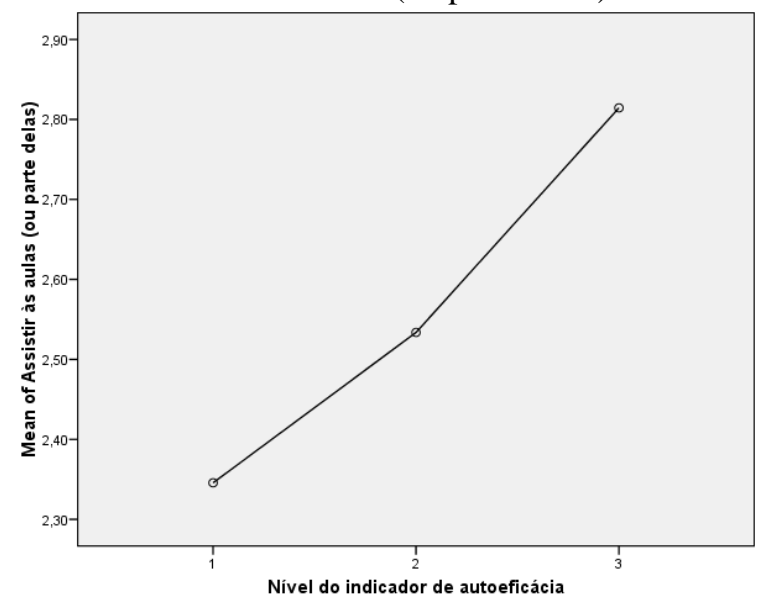

Fonte: Questionário do diretor

Gráfico: Elaborar relatórios e mapas de notas. 


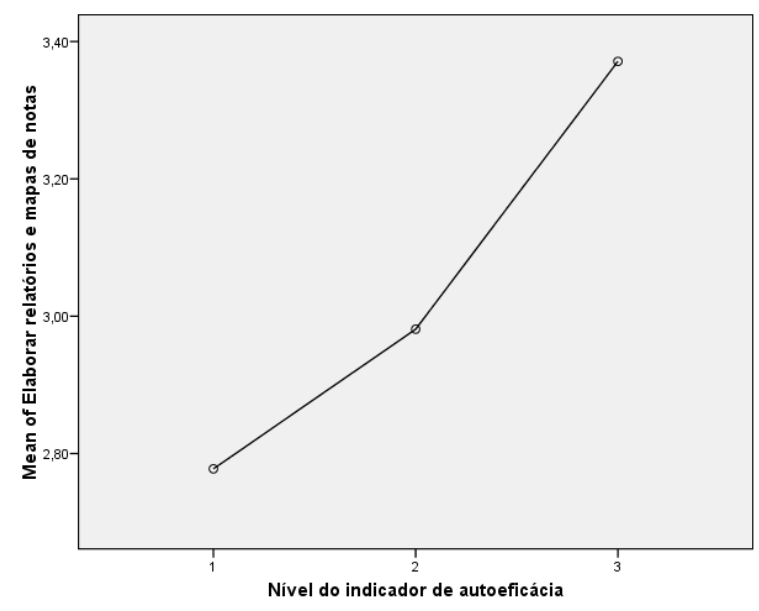

Fonte: Questionário do diretor.

Gráfico: Orientar o planejamento escolar (conteúdos a priorizar, estratégias de ensino e formas de avaliação):

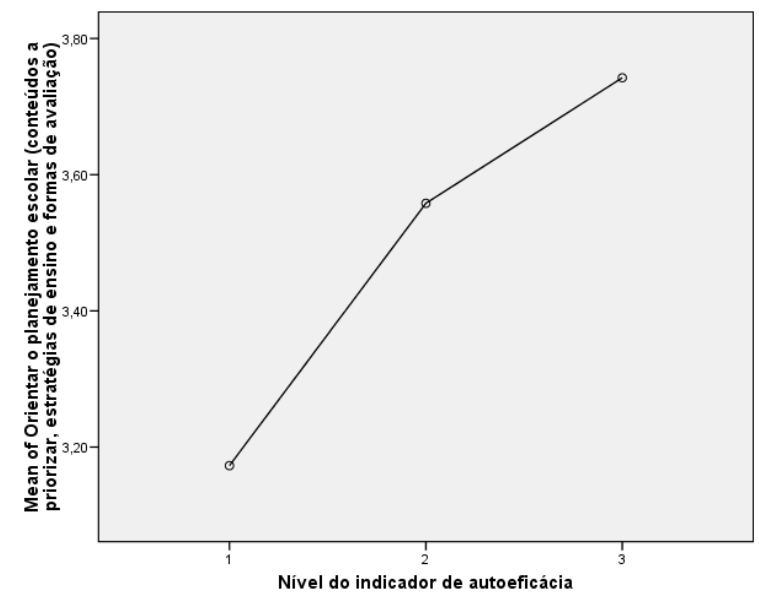

Fonte: Questionário do diretor

Gráfico: Conversar com os professores sobre o desempenho de seus alunos nas avaliações.

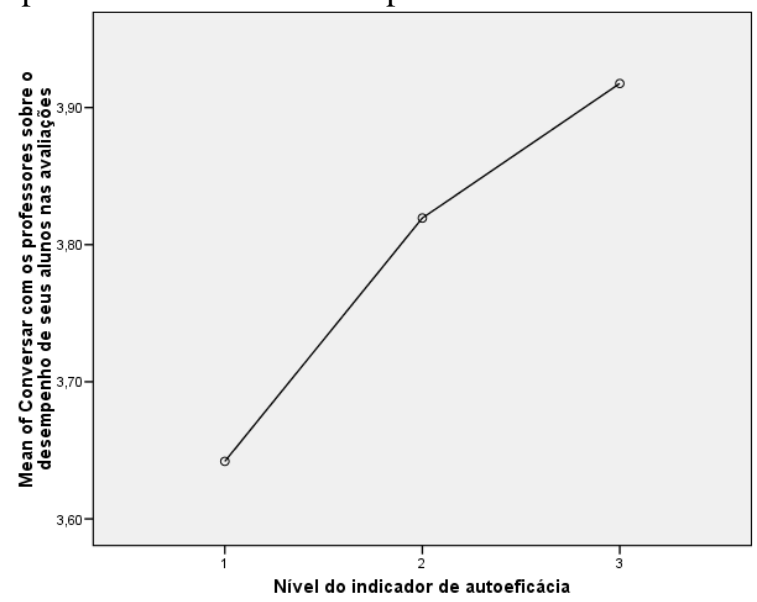

Fonte: Questionário do diretor.

Tabela: Estatística Descritiva do Indicado de autoeficácia do diretor e uso das fontes de informação de MG. 
Descriptives

Indicador de autoeficácia do diretor com base nas variáveis 7 de 1 a 3

\begin{tabular}{|c|c|c|c|c|c|c|c|c|}
\hline & \multirow[b]{2}{*}{$\mathrm{N}$} & \multirow[b]{2}{*}{ Mean } & \multirow[b]{2}{*}{ Std. Deviation } & \multirow[b]{2}{*}{ Std. Error } & \multicolumn{2}{|c|}{$\begin{array}{c}95 \% \text { Confidence Interval for } \\
\text { Mean }\end{array}$} & \multirow[b]{2}{*}{ Minimum } & \multirow[b]{2}{*}{ Maximum } \\
\hline & & & & & Lower Bound & Upper Bound & & \\
\hline Não & 12 &,- 257 & 8243 & 2380 &,- 781 & 267 & $-1,4$ & $\overline{1,3}$ \\
\hline Sim & 574 & ,005 & 1,0032 &, 0419 &,- 077 & ,088 & $-3,8$ & 1,9 \\
\hline Total & 586 &, 000 & 1,0000 &, 0413 &,- 081 & ,081 & $-3,8$ & 1,9 \\
\hline
\end{tabular}

Fonte: Questionário do diretor.

$\mathrm{N}$ se refere ao número de diretores; Mean é a média de cada medida; Std. Deviation é o desvio padrão; Std. Error é o erro padrão, que corresponde à média dividida pela raiz quadrada de $\mathrm{N}$; Lower Bound e Upper Bound correspondem, respectivamente ao limite inferior e superior de intervalos de $95 \%$ de confiança para as médias de cada um dos três grupos de respondentes. Por fim, os valores mínimo (Minimum) e máximo (Maximum) de cada resposta.

Gráfico: Indicador de autoeficácia do diretor e o uso de fontes de MG.

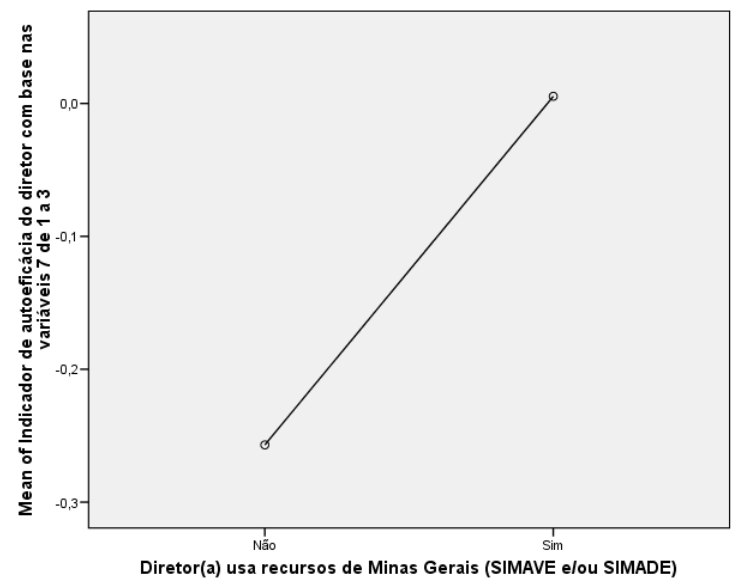

Fonte: Questionário do diretor.

Tabela: Estatística descritiva do indicador de autoeficácia do diretor e uso das fontes de informação do MEC.

Descriptives

Indicador de autoeficácia do diretor com base nas variáveis 7 de 1 a 3

\begin{tabular}{|c|c|c|c|c|c|c|c|c|}
\hline & \multirow[b]{2}{*}{$\mathrm{N}$} & \multirow[b]{2}{*}{ Mean } & \multirow[b]{2}{*}{ Std. Deviation } & \multirow[b]{2}{*}{ Std. Error } & \multicolumn{2}{|c|}{$\begin{array}{l}\text { 95\% Confidence Interval for } \\
\text { Mean }\end{array}$} & \multirow[b]{2}{*}{ Minimum } & \multirow[b]{2}{*}{ Maximum } \\
\hline & & & & & Lower Bound & Upper Bound & & \\
\hline Não & 59 &,- 317 & 9732 & 1267 &,- 571 &,- 063 & $-3,1$ & $\overline{1,9}$ \\
\hline Sim & 527 &, 035 & ,9976 &, 0435 &,- 050 & , 121 & $-3,8$ & 1,9 \\
\hline Total & 586 &, 000 & 1,0000 &, 0413 &,- 081 &, 081 & $-3,8$ & 1,9 \\
\hline
\end{tabular}

Fonte: Questionário do diretor.

$\mathrm{N}$ se refere ao número de diretores; Mean é a média de cada medida; Std. Deviation é o desvio padrão; Std. Error é o erro padrão, que corresponde à média dividida pela raiz quadrada de $\mathrm{N}$; Lower Bound e Upper Bound correspondem, respectivamente ao limite inferior e superior de intervalos de $95 \%$ de confiança para as médias de cada um dos três grupos de respondentes. Por fim, os valores mínimo (Minimum) e máximo (Maximum) de cada resposta.

Tabela: Indicador de autoeficácia do diretor e o uso das fontes de informação do MEC.

\begin{tabular}{|l|c|c|c|c|c|}
\hline & $\begin{array}{c}\text { Sum of } \\
\text { Squares }\end{array}$ & df & Mean & & Square \\
\hline Between Groups & 6,590 & 1 & 6,590 & 6,654 &, 010 \\
Within Groups & 578,410 & 584 &, 990 & & \\
Total & 585,000 & 585 & & & \\
\hline
\end{tabular}

Fonte: Questionário do diretor. 
Gráfico: Indicador de autoeficácia do diretor e o uso de fontes do MEC.

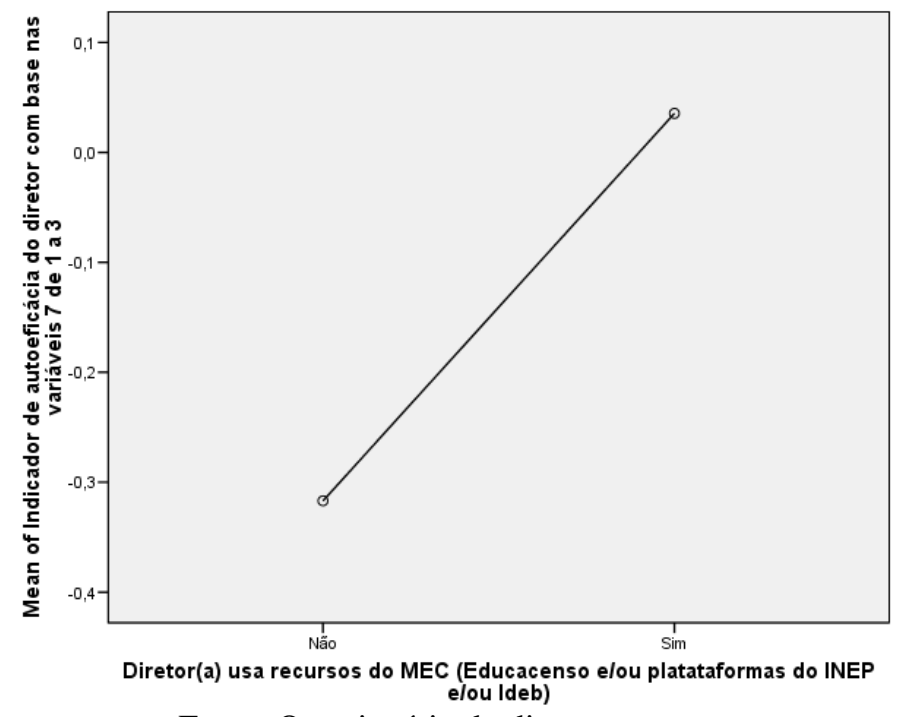

Fonte: Questionário do diretor.

Tabela 40: Estatística descritiva do indicador de autoeficácia do diretor e uso das fontes de informação de sites.

Descriptives

Indicador de autoeficácia do diretor com base nas variáveis 7 de 1 a 3

\begin{tabular}{|c|c|c|c|c|c|c|c|c|}
\hline & \multirow[b]{2}{*}{$\mathrm{N}$} & \multirow[b]{2}{*}{ Mean } & \multirow[b]{2}{*}{ Std. Deviation } & \multirow[b]{2}{*}{ Std. Error } & \multicolumn{2}{|c|}{$\begin{array}{l}\text { 95\% Confidence Interval for } \\
\text { Mean }\end{array}$} & \multirow[b]{2}{*}{ Minimum } & \multirow[b]{2}{*}{ Maximum } \\
\hline & & & & & Lower Bound & Upper Bound & & \\
\hline Não & 472 &,- 056 & ,9924 &, 0457 &,- 146 &, 034 & $-3,8$ & $\overline{1,9}$ \\
\hline Sim & 114 & ,231 & 1,0025 &, 0939 &, 045 &, 417 & $-2,5$ & 1,9 \\
\hline Total & 586 &, 000 & 1,0000 &, 0413 &,- 081 &, 081 & $-3,8$ & 1,9 \\
\hline
\end{tabular}

Fonte: Questionário do diretor

$\mathrm{N}$ se refere ao número de diretores; Mean é a média de cada medida; Std. Deviation é o desvio padrão; Std. Error é o erro padrão, que corresponde à média dividida pela raiz quadrada de $\mathrm{N}$; Lower Bound e Upper Bound correspondem, respectivamente ao limite inferior e superior de intervalos de $95 \%$ de confiança para as médias de cada um dos três grupos de respondentes. Por fim, os valores mínimo (Minimum) e máximo (Maximum) de cada resposta.

Tabela: Indicador de autoeficácia do diretor e o uso das fontes de informação de Sites.

\begin{tabular}{|l|r|r|r|r|r|}
\hline & Sum of Squares & \multicolumn{1}{|c|}{ df } & Mean Square & \multicolumn{1}{c|}{ F } & Sig. \\
\hline Between Groups & 7,564 & 1 & 7,564 & 7,650 &, 006 \\
Within Groups & 577,436 & 584 &, 989 & & \\
Total & 585,000 & 585 & & & \\
\hline
\end{tabular}

Fonte: Questionário do diretor.

Sum of squares é a soma dos quadrados; DF é o desvio padrão; Mean Square é a média dos quadrados; F e Sig é a significância. 
Gráfico: Indicador de autoeficácia do diretor e o uso de fontes de Sites.

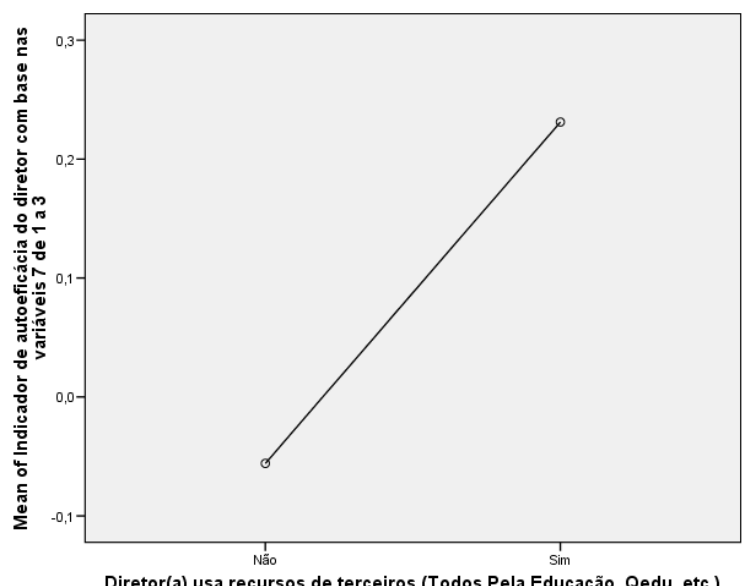

Fonte: Questionário do diretor.

Tabela: Estatística descritiva do Indicado de autoeficácia do diretor e uso das fontes da própria Escola.

Descriptives

Indicador de autoeficácia do diretor com base nas variáveis 7 de 1 a 3

\begin{tabular}{|c|c|c|c|c|c|c|c|c|}
\hline & \multirow[b]{2}{*}{$\mathrm{N}$} & \multirow[b]{2}{*}{ Mean } & \multirow[b]{2}{*}{ Std. Deviation } & \multirow[b]{2}{*}{ Std. Error } & \multicolumn{2}{|c|}{$\begin{array}{l}\text { 95\% Confidence Interval for } \\
\text { Mean }\end{array}$} & \multirow[b]{2}{*}{ Minimum } & \multirow[b]{2}{*}{ Maximum } \\
\hline & & & & & Lower Bound & Upper Bound & & \\
\hline Não & 110 &,- 106 & 1,0880 & ,1037 &,- 311 &, 100 & $-3,8$ & $\overline{1,9}$ \\
\hline Sim & 476 &, 024 & ,9781 &, 0448 &,- 064 &, 113 & $-3,2$ & 1,9 \\
\hline Total & 586 &, 000 & 1,0000 &, 0413 &,- 081 &, 081 & $-3,8$ & 1,9 \\
\hline
\end{tabular}

Fonte: Questionário do diretor.

$\mathrm{N}$ se refere ao número de diretores; Mean é a média de cada medida; Std. Deviation é o desvio padrão; Std. Error é o erro padrão, que corresponde à média dividida pela raiz quadrada de $\mathrm{N}$; Lower Bound e Upper Bound correspondem, respectivamente ao limite inferior e superior de intervalos de $95 \%$ de confiança para as médias de cada um dos três grupos de respondentes. Por fim, os valores mínimo (Minimum) e máximo (Maximum) de cada resposta.

Tabela: ANOVA - Indicador de autoeficácia do diretor e o uso das fontes de informação de Sites.

\begin{tabular}{|l|r|r|r|r|r|}
\hline & $\begin{array}{c}\text { Sum of } \\
\text { Squares }\end{array}$ & F & \multicolumn{1}{|c|}{$\begin{array}{c}\text { Mean } \\
\text { Square }\end{array}$} & & ig. \\
\hline Between Groups & 1,512 & 1 & 1,512 & 1,51 &, 219 \\
& 583,488 & 584 &, 999 & & \\
Within Groups & 585,000 & 585 & & & \\
Total & & & \\
\hline
\end{tabular}

Fonte: Questionário do diretor.

Sum of squares é a soma dos quadrados; DF é o desvio padrão; Mean Square é a média dos quadrados; F e Sig é a significância. 
Gráfico: Indicador de autoeficácia do diretor e o uso de fontes da própria Escola.

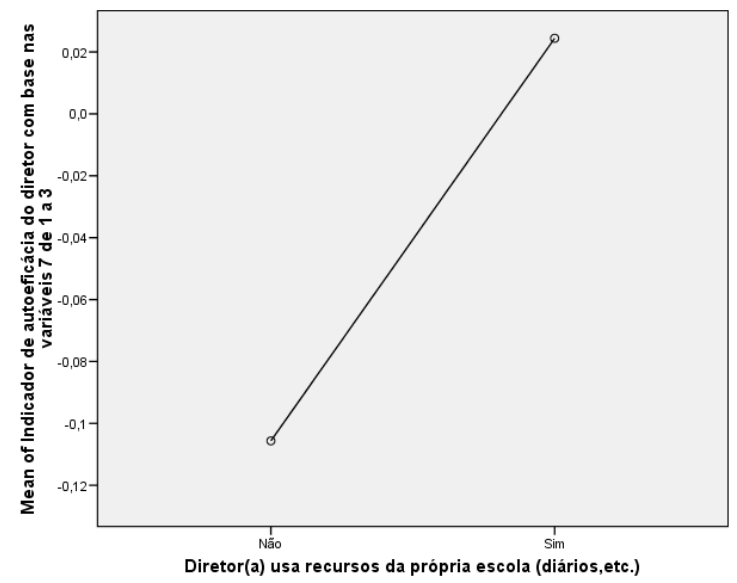

Fonte: Questionário do diretor.

Tabela 50: Estatística descritiva da ANOVA

\begin{tabular}{|c|c|c|c|c|c|c|c|c|c|}
\hline \multirow{2}{*}{ Variáveis } & \multirow{2}{*}{$\begin{array}{l}\text { Níveis de } \\
\text { autoeficácia }\end{array}$} & \multirow{2}{*}{$\begin{array}{c}\mathrm{N} \\
\text { Lower Bound } \\
\end{array}$} & \multirow{2}{*}{\begin{tabular}{|c|} 
Mean \\
Upper Bound \\
\end{tabular}} & \multirow{2}{*}{$\begin{array}{l}\text { Std. Deviation } \\
\text { Lower Bound } \\
\end{array}$} & \multirow{2}{*}{$\begin{array}{c}\text { Std. Error } \\
\text { Upper Bound } \\
\end{array}$} & \multicolumn{2}{|c|}{ 95\% Confidence Interval for Mean } & \multirow{2}{*}{$\begin{array}{l}\text { Minimum } \\
\text { Lower Bound }\end{array}$} & \multirow{2}{*}{$\begin{array}{l}\text { Maximum } \\
\text { Upper Bound }\end{array}$} \\
\hline & & & & & & Lower Bound & Upper Bound & & \\
\hline \multirow{4}{*}{$\begin{array}{l}\text { Considero a utilização do } \\
\text { SIMADE bastante fácil }\end{array}$} & 1 & 81 & 2,740740741 & 0,703167437 & 0,078129715 & 2,585257652 & 2,8962238229 & 1 & 4 \\
\hline & 2 & 374 & 2,983957219 & 0,646507929 & 0,033430129 & 2,918222075 & 3,049692363 & 1 & 4 \\
\hline & 3 & 97 & 3,195876289 & 0,606203611 & 0,061550651 & 3,073699212 & 3,318053366 & 1 & 4 \\
\hline & Total & 552 & 2,985507246 & 0,659819117 & 0,028083767 & 2,930342902 & 3,040671591 & 1 & 4 \\
\hline \multirow{4}{*}{$\begin{array}{l}\text { Utilizar o SIMADE é algo } \\
\text { que raramente gosto }\end{array}$} & 1 & 81 & 2,061728395 & 0,841808752 & 0,093534306 & 1,875589194 & 2,247867596 & 1 & 4 \\
\hline & 2 & 374 & 1,935828877 & 0,848369976 & 0,043868167 & 1,849568957 & 2,022088797 & 1 & 4 \\
\hline & 3 & 97 & 1,742268041 & 0,938508907 & 0,095291142 & 1,553116619 & 1,931419463 & 1 & 4 \\
\hline & Total & 552 & 1,920289855 & 0,867326612 & 0,036915872 & 1,847776794 & 1,992802916 & 1 & 4 \\
\hline \multirow{4}{*}{$\begin{array}{c}\text { Estou bastante confiante } \\
\text { na minha capacidade para } \\
\text { utilizar o SIMADE }\end{array}$} & 1 & 81 & 2,827160494 & 0,771202364 & 0,085689152 & 2,656633648 & 2,99768734 & 1 & 4 \\
\hline & 2 & 374 & 2,93315508 & 0,727345751 & 0,037610153 & 2,859200569 & 3,007109591 & 1 & 4 \\
\hline & 3 & 97 & 3,371134021 & 0,634422106 & 0,064415805 & 3,243269658 & 3,498998383 & 2 & 4 \\
\hline & Total & 552 & 2,994565217 & 0,739087208 & 0,031457641 & 2,932773644 & 3,056356791 & 1 & 4 \\
\hline \multirow{4}{*}{$\begin{array}{l}\text { OSIMADE me ajuda a } \\
\text { poupar tempo na } \\
\text { realização de minhas } \\
\text { atividades }\end{array}$} & 1 & 81 & 2,9382716005 & 0,730508025 & 0,081167558 & 2,776743016 & 3,099800194 & 1 & 4 \\
\hline & 2 & 374 & 3,085561497 & 0,804248158 & 0,041586682 & 3,03787762 & 3,167335233 & 1 & 4 \\
\hline & 3 & 97 & 3,4123711134 & 0,673185483 & 0,06835163 & 3,276694221 & 3,548048047 & 1 & 4 \\
\hline & Total & 552 & 3,121376812 & 0,784222543 & 0,033378728 & 3,055811687 & 3,186941936 & 1 & 4 \\
\hline
\end{tabular}

Fonte: Questionário do diretor.

$\mathrm{N}$ se refere ao número de diretores; Mean é a média de cada medida; Std. Deviation é o desvio padrão; Std. Error é o erro padrão, que corresponde à média dividida pela raiz quadrada de $\mathrm{N}$; Lower Bound e Upper Bound correspondem, respectivamente ao limite inferior e superior de intervalos de $95 \%$ de confiança para as médias de cada um dos três grupos de respondentes. Por fim, os valores mínimo (1) e máximo (4) de cada resposta. 
Tabela 51: ANOVA do indicador de autoeficácia e a concordância com as seguintes alternativas

\begin{tabular}{|c|c|c|c|c|c|c|c|c|}
\hline \multirow[b]{2}{*}{ Variáveis } & \multirow[b]{2}{*}{ Grupos } & \multirow[b]{2}{*}{ Sum of Squares } & \multirow[b]{2}{*}{ df } & \multirow{2}{*}{$\begin{array}{l}\text { Mean } \\
\text { Square }\end{array}$} & \multirow[b]{2}{*}{$\mathrm{F}$} & \multirow[b]{2}{*}{ Sig. } & \multicolumn{2}{|c|}{$\begin{array}{l}\text { Significativo no nível } \\
\text { de confiança de }\end{array}$} \\
\hline & & & & & & & $95 \%$ & $99 \%$ \\
\hline \multirow{3}{*}{$\begin{array}{c}\text { Considero a utilização do SIMADE } \\
\text { bastante fácil }\end{array}$} & Between Groups & 9,146408584 & 2 & 4,573204 & & & & \\
\hline & Within Groups & 230,7376494 & 549 & 0,420287 & 10,88114 & 0,000023208 & Sim & Sim \\
\hline & Total & 239,884058 & 551 & & & & & \\
\hline \multirow{3}{*}{$\begin{array}{l}\text { Utilizar o SIMADE é algo que raramente } \\
\text { gosto }\end{array}$} & Between Groups & 4,784801519 & 2 & 2,392401 & & & & \\
\hline & Within Groups & 409,7079521 & 549 & 0,74628 & 3,205766 & 0,0412876616 & Sim & Não \\
\hline & Total & 414,4927536 & 551 & & & & & \\
\hline \multirow{3}{*}{$\begin{array}{l}\text { Estou bastante confiante na minha } \\
\text { capacidade para utilizar o SIMADE }\end{array}$} & Between Groups & 17,43539648 & 2 & 8,717698 & 16,87902 & & & \\
\hline & Within Groups & 283,5482992 & 549 & 0,516481 & & 0,0000000769 & Sim & Sim \\
\hline & Total & 300,9836957 & 551 & & & & & \\
\hline \multirow{3}{*}{$\begin{array}{l}\text { O SIMADE me ajuda a poupar tempo na } \\
\text { realização de minhas atividades }\end{array}$} & Between Groups & 11,40920887 & 2 & 5,704604 & & & & \\
\hline & Within Groups & 327,4585447 & 549 & 0,596464 & 9,564044 & 0,0000826247 & Sim & Sim \\
\hline & Total & 338,8677536 & 551 & & & & & \\
\hline
\end{tabular}

Fonte: Questionário do diretor.

Gráfico : Utilizar o SIMADE é algo que raramente gosto.

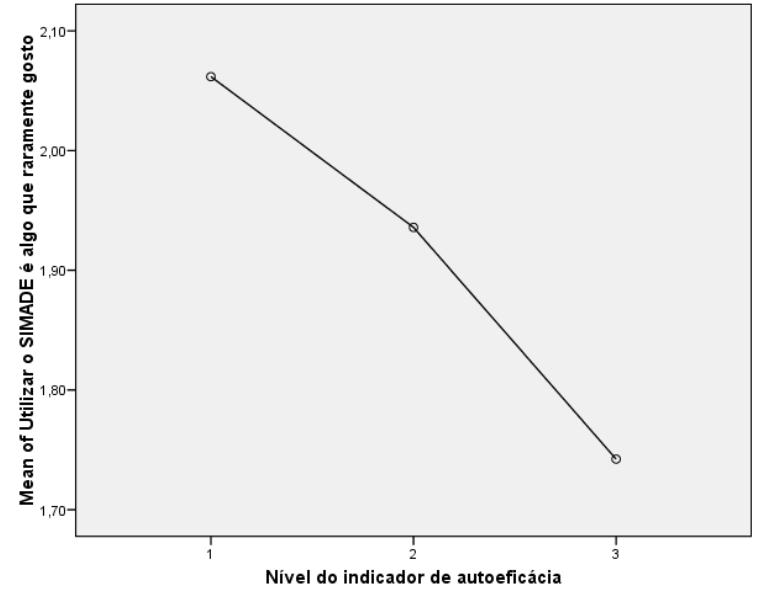

Fonte: Questionário do diretor. 


\section{Anexo 10}

Indicador de desempenho bruto das escolas da amostra

Ao mesmo tempo, ao se elaborar o indicador de desempenho bruto, também houve um interesse em verificar o desempenho relativo das escolas, ou seja, ver como umas estavam se comportando em relação às outras. Porém, nesse sentido, um aspecto que poderia comprometer tal comparabilidade é o fato de que nem todas as escolas fizeram os mesmos testes. Houve, por exemplo, casos de escolas que só tiveram alunos do $5^{\circ}$ ano fazendo as provas, mas não alunos do $9^{\circ}$ ano, visto que, às vezes, as escolas somente ofereciam ensino em um desses anos, mas não em ambos. Dessa forma, essas escolas poderiam ficar prejudicadas pelo simples fato de, no cômputo médio de suas respectivas médias de proficiência, só entrarem os resultados expressos no lado inferior da escala de desempenho (referentes ao $5^{\circ}$ ano do Ensino Fundamental), não considerando os resultados do lado superior ( $9^{\circ}$ ano do Ensino Fundamental). Evidentemente, o inverso também poderia ocorrer com aquelas escolas para as quais só havia resultados do $9^{\circ}$ ano.

Para evitar esse problema, foi realizada uma padronização das quatro distribuições de médias escolares de matemática: $5^{\circ}$ e $9^{\circ}$ anos do Ensino Fundamental na Prova Brasil de 2015 e também no SIMAVE de 2016. Ou seja, em cada um dos testes, procedeu-se segundo o seguinte cálculo:

$X_{i j k} *\left(X_{i j k}-\mu_{j k}\right) / \sigma_{j k}$

onde:

$X_{i j k} *$ : média de proficiência padronizada da escola $i$ no ano $j$ (5 ou 9) do Ensino Fundamental, na edição k do teste (Prova Brasil/2015 ou SIMAVE/2016) $X_{i j k}$ : média de proficiência bruta da escola $i$ no ano $j$ na edição $k$ do teste $\mu_{j k}$ : grande média da distribuição das médias escolares do ano $j$ e edição $k$

$\sigma_{j k}$ : desvio-padrão da distribuição das médias escolares do ano $j$ e edição $k$

Com base nisso, cada uma dessas quatro medidas passou a ser expressa segundo uma distribuição aproximadamente normal e padronizada, de média 0 e desvio-padrão 1. A partir daí, calculou-se então a média dessas quatro medidas, para se chegar ao indicador geral de desempenho. No caso específico das escolas que só apresentaram resultados para um dos anos do Ensino Fundamental ( $5^{\circ}$ ou $9^{\circ}$ ), ou para apenas uma das edições do teste (2015 ou 2016), houve, naturalmente, 
menos dados para o cálculo da média. Porém, o possível desequilíbrio decorrente dessa falta de dados, cobrindo diferentes regiões da escala de proficiência, foi evitado com o procedimento de padronização acima mencionado. 


\section{Anexo 11}

Quadro: Autoeficácia do diretor

\begin{tabular}{|c|c|c|c|c|c|c|c|c|c|c|c|}
\hline & $\begin{array}{l}\text { Em seu atual papel como gestor(a) escolar, quanto você } \\
\text { se percebe capaz de.... }\end{array}$ & 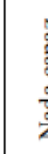 & & & 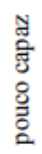 & & ל. & & & & 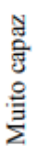 \\
\hline 1 & Facilitar a aprendizagem dos alunos em sua escola? & 1 & 2 & 3 & 4 & 5 & 6 & 7 & 8 & 9 & 10 \\
\hline 2 & Gerar entusiasmo para uma visão compartilhada sobre a escola? & 1 & 2 & 3 & 4 & 5 & 6 & 7 & 8 & 9 & 10 \\
\hline 3 & Administrar as demandas de tempo do trabalho? & 1 & 2 & 3 & 4 & 5 & 6 & 7 & 8 & 9 & 10 \\
\hline 4 & Gerenciar as mudanças em sua escola? & 1 & 2 & 3 & 4 & 5 & 6 & 7 & 8 & 9 & 10 \\
\hline 5 & Promover a valorização da escola entre a maioria dos alunos? & 1 & 2 & 3 & 4 & 5 & 6 & 7 & 8 & 9 & 10 \\
\hline 6 & Criar um ambiente de aprendizagem positivo em sua escola? & 1 & 2 & 3 & 4 & 5 & 6 & 7 & 8 & 9 & 10 \\
\hline 7 & $\begin{array}{l}\text { Elevar o desempenho dos alunos em testes padronizados, como } \\
\text { SARESP, SAEB, ENEM, dentre outros? }\end{array}$ & 1 & 2 & 3 & 4 & 5 & 6 & 7 & 8 & 9 & 10 \\
\hline 8 & Promover uma imagem positiva da sua escola na comunidade? & 1 & 2 & 3 & 4 & 5 & 6 & 7 & 8 & 9 & 10 \\
\hline 9 & Motivar os professores? & 1 & 2 & 3 & 4 & 5 & 6 & 7 & 8 & 9 & 10 \\
\hline 10 & Promover os valores da comunidade em sua escola? & 1 & 2 & 3 & 4 & 5 & 6 & 7 & 8 & 9 & 10 \\
\hline 11 & Manter o controle da sua agenda diária? & 1 & 2 & 3 & 4 & 5 & 6 & 7 & 8 & 9 & 10 \\
\hline 12 & $\begin{array}{l}\text { Planejar as práticas e os procedimentos operacionais que são } \\
\text { necessários para realizar o seu trabalho? }\end{array}$ & 1 & 2 & 3 & 4 & 5 & 6 & 7 & 8 & 9 & 10 \\
\hline 13 & Lidar efetivamente com a disciplina em sua escola? & 1 & 2 & 3 & 4 & 5 & 6 & 7 & 8 & 9 & 10 \\
\hline 14 & Promover comportamento aceitável entre os alunos? & 1 & 2 & 3 & 4 & 5 & 6 & 7 & 8 & 9 & 10 \\
\hline 15 & Lidar com o trabalho burocrático requerido pela função? & 1 & 2 & 3 & 4 & 5 & 6 & 7 & 8 & 9 & 10 \\
\hline 16 & Promover comportamento ético entre os funcionários da escola? & 1 & 2 & 3 & 4 & 5 & 6 & 7 & 8 & 9 & 10 \\
\hline 17 & Lidar com o estresse do trabalho? & 1 & 2 & 3 & 4 & 5 & 6 & 7 & 8 & 9 & 10 \\
\hline 18 & Estabelecer prioridades entre as diversas demandas do trabalho? & 1 & 2 & 3 & 4 & 5 & 6 & 7 & 8 & 9 & 10 \\
\hline
\end{tabular}

